Supporting Information for

\title{
Alkylamine-Substituted Perthiocarbamates: Dual Precursors to Hydropersulfide and Carbonyl Sulfide with Cardioprotective Actions
}

\footnotetext{
Vinayak S. Khodade, ${ }^{\dagger}$ Blaze M. Pharoah, ${ }^{\dagger}$ Nazareno Paolocci,,$£ \S$ and John P. Toscano ${ }^{*} \dagger$

'Department of Chemistry, Johns Hopkins University, Baltimore, Maryland Division of Cardiology, Johns Hopkins University School of Medicine, Baltimore, Maryland ${ }^{\S}$ Department of Biomedical Sciences, University of Padova, Padova, Italy
} 
Table of Contents

\begin{tabular}{|l|l|}
\hline General information & $\mathrm{S} 3$ \\
\hline Chemical synthesis & $\mathrm{S} 4$ \\
\hline RSSH generation from precursor 1a in the presence of HPE-IAM & $\mathrm{S} 12$ \\
\hline RSSH generation from precursor 1a in the presence of $N$-ethyl maleimide & $\mathrm{S} 14$ \\
\hline RSSH generation and quantification of cyclic-ureas 2a-d from 7a-d by UPLC-MS & $\mathrm{S} 17$ \\
\hline Reactivity of control compound $\mathbf{8}$ & $\mathrm{S} 24$ \\
\hline Kinetics of RSSH release from 7a-d monitored by HPLC & $\mathrm{S} 29$ \\
\hline Kinetics of RSSH release from 7a monitored by UPLC-MS & $\mathrm{S} 34$ \\
\hline Analysis of RSSH generation from 7a in the presence of $N$-acetyl cysteine & $\mathrm{S} 35$ \\
\hline Decomposition of 7a in the absence of a trapping agent & $\mathrm{S} 40$ \\
\hline Decomposition of $\mathbf{1 a}$ in absence of a trapping agent & $\mathrm{S} 44$ \\
\hline Analysis of RSSH generation from 7b-d in the presence of $N$-acetyl cysteine & $\mathrm{S} 48$ \\
\hline Comparison of RSSH release from 7b with NAC at pH 6.0 and 7.4 & $\mathrm{S} 61$ \\
\hline RSSH generation from precursor 7b in the presence of glutathione & $\mathrm{S} 62$ \\
\hline Analysis of COS release from 7a-d in the presence of $N$-acetyl cysteine using MIMS & $\mathrm{S} 67$ \\
\hline Purity determination of $\mathbf{4}$ by UPLC-MS & $\mathrm{S} 68$ \\
\hline Cytotoxicity study of 7b & $\mathrm{S} 69$ \\
\hline H9c2 cell protection by precursor 7b from $\mathrm{H}_{2} \mathrm{O}_{2}$-mediatd oxidative stress & $\mathrm{S} 70$ \\
\hline Isolated perfused heart protocol and infarct size determination & $\mathrm{S} 71$ \\
\hline NMR spectra of synthesized compounds & $\mathrm{S} 72$ \\
\hline References & $\mathrm{S} 96$ \\
\hline
\end{tabular}




\section{General Information}

Analytical thin layer chromatography (TLC) was performed on silica gel on TLC Al foils with fluorescent indicator F254 plates (Sigma-Aldrich). Visualization was accomplished with UV light $(254 \mathrm{~nm})$ or staining with $\mathrm{KMnO}_{4}$. Starting materials, solvents, and reagents were received from commercial sources (Sigma-Aldrich, Oakwood Chemical, and TCI), unless otherwise noted and were used without purification. Deuterated solvents (Cambridge Isotope Laboratories) were used for NMR spectroscopic analyses. NMR spectra were obtained on a Bruker $400 \mathrm{MHz} \mathrm{NMR}$ spectrometer. In the case of ${ }^{1} \mathrm{H} \mathrm{NMR}$ in $\mathrm{CDCl}_{3}$, chemical shifts are reported relative to tetramethylsilane $(\delta=0)$. The other spectra are referenced internally according to residual solvent signals of $\mathrm{CDCl}_{3}\left({ }^{13} \mathrm{C} \mathrm{NMR} ; \delta=77.16 \mathrm{ppm}\right)$, and DMSO- $d_{6}\left({ }^{1} \mathrm{H} \mathrm{NMR} ; \delta=2.50 \mathrm{ppm},{ }^{13} \mathrm{C} \mathrm{NMR}\right.$; $\delta=39.52 \mathrm{ppm})$. High-resolution mass spectra were obtained on a Waters Acquity Q-ToF MS/MS instrument. The kinetics of RSSH generation were measured using a high-performance liquid chromatography (HPLC, Agilent 1100 series) system with a Phenomenex C-18 reverse phase column $(250 \mathrm{~mm} \times 4.6 \mathrm{~mm}, 5 \mu \mathrm{m})$. UPLC-MS analysis was carried out with a Waters Acquity/Xevo-G2 UPLC-MS system equipped with ACQUITY UPLC BEH C18 column (2.1 mm $\times 50 \mathrm{~mm}, 1.7 \mu \mathrm{m})$. The mass signals for products of RSSH trapping with $\beta$-(4hydroxyphenyl)ethyl iodoacetamide (HPE-IAM) were obtained via deconvolution using MassLynx 4.1 software. In addition to the protonated molecule $[\mathrm{M}+\mathrm{H}]^{+}$, we also observe $[\mathrm{M}+\mathrm{Na}]^{+}$ adduct during ESI-MS analysis. The $\mathrm{pH}$ measurements were performed using a Fisher Scientific Accumet AB15 pH-meter. 


\section{Chemical synthesis}

tert-Butyl (2-(methylamino)ethyl)carbamate and tert-butyl (3-(methylamino)propyl)carbamate were received from the commercial sources. tert-Butyl methyl(2-(methylamino)ethyl)carbamate ${ }^{1}$ and tert-butyl methyl(3-(methylamino)propyl)carbamate ${ }^{2}$ were synthesized using a previously reported procedure and the analytical data collected was consistent with the reported values.

General note- ${ }^{1} \mathrm{H}$ and ${ }^{13} \mathrm{C}$ NMR spectra of compounds 4, S1a, S1b, S1c, S1d, and 8 show two sets of some signals at $24{ }^{\circ} \mathrm{C}$, likely due to the presence of rotamers. Hence, we report ${ }^{1} \mathrm{H}$ and ${ }^{13} \mathrm{C}$ NMR spectra acquired at $24{ }^{\circ} \mathrm{C}$, and $70^{\circ} \mathrm{C}$ or $80^{\circ} \mathrm{C}$ to distinguish these rotamers.

\section{Methyl-13-acetamido-2,2,5,8-tetramethyl-4,9-dioxo-3-oxa-10,11-dithia-5,8-diazatetradecan-} 14-oate (4)

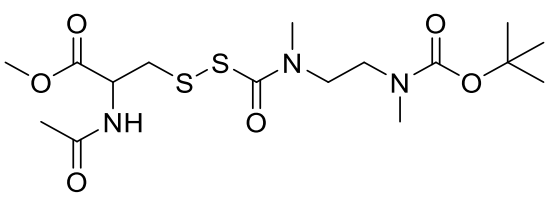

A solution of chlorocarbonylsulfenyl chloride $(288 \mathrm{mg}, 2.2 \mathrm{mmol})$ in dichloromethane $(4 \mathrm{~mL})$ was added dropwise to the solution of $N$-acetyl-cysteine methyl ester $(354 \mathrm{mg}, 2 \mathrm{mmol})$ in dichloromethane $(4 \mathrm{~mL})$ at $0{ }^{\circ} \mathrm{C}$ under a nitrogen atmosphere. The reaction mixture was stirred at $0{ }^{\circ} \mathrm{C}$ for $1 \mathrm{~h}$ and volatiles were removed under vacuum to obtain $S$-perthiocarbonyl chloride 3 . This compound was immediately dissolved in anhydrous dichloromethane $(3 \mathrm{~mL})$ and added slowly into a cold solution $\left(0{ }^{\circ} \mathrm{C}\right)$ of tert-butyl methyl $(2$-(methylamino)ethyl)carbamate $(376 \mathrm{mg}$, $2 \mathrm{mmol}$ ) and triethylamine (223 $\mathrm{mg}, 2.2 \mathrm{mmol})$ in dichloromethane $(5 \mathrm{~mL})$. The reaction mixture was stirred at $0{ }^{\circ} \mathrm{C}$ for $1 \mathrm{~h}$, quenched with water $(20 \mathrm{~mL})$ and extracted with dichloromethane $(3 \mathrm{x}$ $10 \mathrm{~mL})$. The combined organic layer was washed with brine $(3 \times 10 \mathrm{~mL})$, dried over anhydrous $\mathrm{Na}_{2} \mathrm{SO}_{4}$, and evaporated under vacuum. The residue was purified by flash column chromatography on silica gel to afford the product 4 (mixture of rotamers) as a semisolid ( $586 \mathrm{mg}, 69 \%$ yield); ${ }^{1} \mathrm{H}$ NMR (400 MHz, DMSO, $\left.24^{\circ} \mathrm{C}\right) \delta 8.43(\mathrm{~d}, J=7.3 \mathrm{~Hz}, 1 \mathrm{H}), 4.51-4.46(\mathrm{~m}, 1 \mathrm{H}), 3.63(\mathrm{~s}, 3 \mathrm{H}), 3.49$ (bs, 2H), 3.34 (bs, 2H), $3.10-2.91(\mathrm{~m}, 5 \mathrm{H}), 2.77$ (s, 3H), $1.86(\mathrm{~s}, 3 \mathrm{H}), 1.37(\mathrm{~s}, 9 \mathrm{H}) ;{ }^{13} \mathrm{C}$ NMR $\left(101 \mathrm{MHz}, \mathrm{DMSO}, 24{ }^{\circ} \mathrm{C}\right) \delta 170.9,169.4,163.9,154.9,154.5,78.8,78.6,52.1,51.1,47.9,47.1$, $46.4,45.6,44.8,35.9,35.4,35.2,34.2,34.0,33.6,28.0,22.3 ;{ }^{1} \mathrm{H}$ NMR $\left(400 \mathrm{MHz}, \mathrm{DMSO}, 70{ }^{\circ} \mathrm{C}\right)$ $\delta 8.21(\mathrm{~d}, J=7.3 \mathrm{~Hz}, 1 \mathrm{H}), 4.56-4.51(\mathrm{~m}, 1 \mathrm{H}), 3.65(\mathrm{~s}, 3 \mathrm{H}), 3.51(\mathrm{t}, J=5.6 \mathrm{~Hz}, 2 \mathrm{H}), 3.36(\mathrm{t}, J=$ $5.6 \mathrm{~Hz}, 2 \mathrm{H}), 3.09-3.03(\mathrm{~m}, 2 \mathrm{H}), 3.00(\mathrm{~s}, 3 \mathrm{H}), 2.80(\mathrm{~s}, 3 \mathrm{H}), 1.87(\mathrm{~s}, 3 \mathrm{H}), 1.40(\mathrm{~s}, 9 \mathrm{H}) ;{ }^{13} \mathrm{C} \mathrm{NMR}$ $\left(101 \mathrm{MHz}, \mathrm{DMSO}, 70{ }^{\circ} \mathrm{C}\right) \delta 170.4,168.9,164.1,154.4,78.4,51.7,51.2,51.1,47.5,45.5,35.0$, 34.0, 27.8, 21.9; HRMS (ESI): $\mathrm{m} / \mathrm{z}$ calcd. for $\mathrm{C}_{16} \mathrm{H}_{29} \mathrm{~N}_{3} \mathrm{O}_{6} \mathrm{~S}_{2} \mathrm{Na}^{+}[\mathrm{M}+\mathrm{Na}]^{+} 446.1390$, found 446.1391.

\section{2-(((2-Acetamido-3-methoxy-3-oxopropyl)disulfannecarbonyl)(methyl)amino)- $N$ - methylethan-1-aminium (1a)}<smiles>COC(=O)C(CSSC(=O)N(C)CCNCC(C)(F)F)NC(C)=O</smiles>

$N$-Boc protected compound $4(252 \mathrm{mg}, 0.59 \mathrm{mmol})$ was dissolved in a 1:1 mixture of dichloromethane: trifluoroacetic acid $(4 \mathrm{~mL})$ and the solution was stirred at room temperature for $1 \mathrm{~h}$. The solvent was evaporated under vacuum, dichloromethane was successively added and 
evaporated to remove the residual TFA, to provide the precursor 1a as a semisolid ( $246 \mathrm{mg}, 95 \%$ yield); ${ }^{1} \mathrm{H}$ NMR (400 MHz, DMSO) $\delta 8.57$ (s, 2H), 8.48 (d, $\left.J=7.7 \mathrm{~Hz}, 1 \mathrm{H}\right), 4.54(\mathrm{td}, J=8.2,5.4$ $\mathrm{Hz}, 1 \mathrm{H}), 3.77-3.51(\mathrm{~m}, 5 \mathrm{H}), 3.25-2.91(\mathrm{~m}, 7 \mathrm{H}), 2.59(\mathrm{~s}, 3 \mathrm{H}), 1.87(\mathrm{~s}, 3 \mathrm{H}) ;{ }^{13} \mathrm{C}$ NMR $(101$ $\left.\mathrm{MHz}, \mathrm{CDCl}_{3}\right) \delta 171.4,171.3,169.0,161.4(\mathrm{q}, J=36.3 \mathrm{~Hz}), 116.2(\mathrm{q}, J=290.3 \mathrm{~Hz}), 52.8,50.9$, 47.3, 47.2, 41.1, 35.7, 33.6, 22.7; HRMS (ESI): $\mathrm{m} / \mathrm{z}$ calcd. for $\mathrm{C}_{11} \mathrm{H}_{22} \mathrm{~N}_{3} \mathrm{O}_{4} \mathrm{~S}_{2}{ }^{+}[\mathrm{M}]^{+}$324.1046, found 324.1052 .

\section{$N$-Acetyl-penicillamine methyl ester}

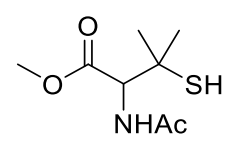

$\mathrm{N}$-acetyl-penicillamine methyl ester was synthesized following a previously reported method. ${ }^{3}$ To a solution of $N$-acetyl- $D$-penicillamine $(1.68 \mathrm{~g}, 8.8 \mathrm{mmol})$ in anhydrous methanol $(40 \mathrm{~mL})$ under a nitrogen atmosphere, chlorotrimethylsilane $(1.91 \mathrm{~g}, 17.6 \mathrm{mmol})$ was added. The mixture was stirred at room temperature for $16 \mathrm{~h}$. The solvent was evaporated under vacuum, and the residue was purified by flash chromatography (silica gel, eluent: $50 \%$ ethyl acetate in hexane) to afford the title compound as a white solid $\left(0.75 \mathrm{~g}, 41 \%\right.$ yield); ${ }^{1} \mathrm{H}$ NMR $\left(400 \mathrm{MHz}, \mathrm{CDCl}_{3}\right) \delta 6.42(\mathrm{~d}, J$ $=8.6 \mathrm{~Hz}, 1 \mathrm{H}), 4.63(\mathrm{~d}, J=9.4 \mathrm{~Hz}, 1 \mathrm{H}), 3.73(\mathrm{~s}, 3 \mathrm{H}), 2.05(\mathrm{~s}, 3 \mathrm{H}), 1.97(\mathrm{~d}, J=1.3 \mathrm{~Hz}, 1 \mathrm{H}), 1.47$ (s, 3H), $1.33(\mathrm{~d}, J=1.2 \mathrm{~Hz}, 3 \mathrm{H}) ;{ }^{13} \mathrm{C}$ NMR $\left(101 \mathrm{MHz}, \mathrm{CDCl}_{3}\right) \delta 171.1,170.0,60.4,52.3,46.6$, 31.2, 29.5, 23.3; HRMS (ESI): $\mathrm{m} / \mathrm{z}$ calcd. for $\mathrm{C}_{8} \mathrm{H}_{15} \mathrm{NO}_{4} \mathrm{~S}$ [M+Na] ${ }^{+} 228.0665$, found 228.0661 .

\section{Scheme S1. Synthesis of alkylamine-substituted perthiocarbamates 7a-d}

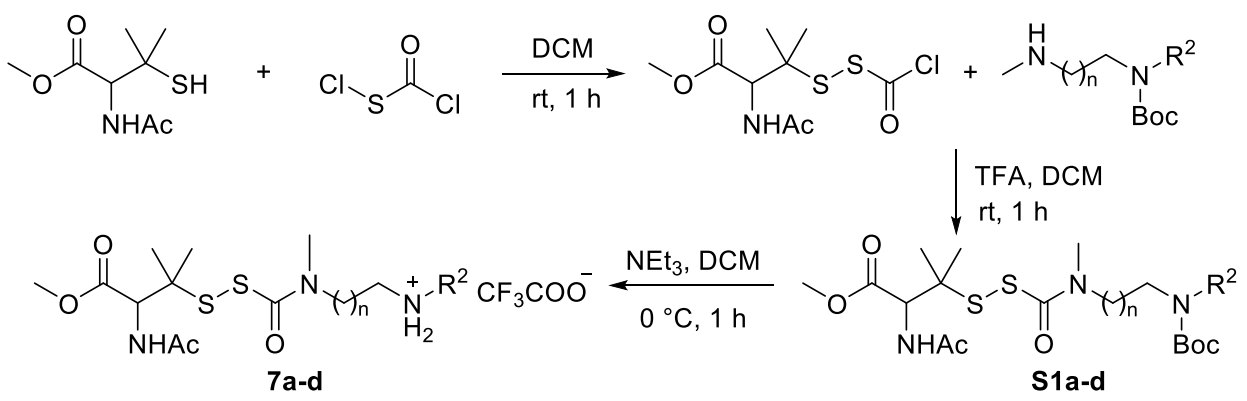

\section{General procedure for synthesis of $\mathrm{N}$-boc protected RSSH/COS precursors (S1a-d)}

A solution of chlorocarbonylsulfenyl chloride (1.1 equiv.) in anhydrous dichloromethane (4 mL) was added dropwise to the solution of $N$-acetyl-penicillamine methyl ester (1 equiv.) in dichloromethane $(4 \mathrm{~mL})$ at $0{ }^{\circ} \mathrm{C}$ under a nitrogen atmosphere. The reaction mixture was stirred at $0{ }^{\circ} \mathrm{C}$ for $1 \mathrm{~h}$, and volatiles were removed under vacuum. The residue was immediately dissolved in anhydrous dichloromethane $(3 \mathrm{~mL})$, and slowly added into a mixture of $N$-Boc protected diamine (1 equiv.) and triethylamine (1.1 equiv.) in dichloromethane $(5 \mathrm{~mL})$ at $0{ }^{\circ} \mathrm{C}$. The resulting solution was stirred at $0{ }^{\circ} \mathrm{C}$ for $1 \mathrm{~h}$. The reaction mixture was quenched by water $(20 \mathrm{~mL})$ and extracted with dichloromethane $(3 \times 10 \mathrm{~mL})$. The combined organic layer was washed with brine ( 3 x $10 \mathrm{~mL}$ ), dried over anhydrous $\mathrm{Na}_{2} \mathrm{SO}_{4}$, and evaporated under vacuum. The residue was purified by flash chromatography on silica gel using ethyl acetate (EA) and petroleum ether (PE) as eluent to afford the desired product as a mixture of rotamers. 
Methyl 13-acetamido-2,2,5,8,12,12-hexamethyl-4,9-dioxo-3-oxa-10,11-dithia-5,8diazatetradecan-14-0ate (S1a)<smiles>COC(=O)C(NC(C)=O)C(C)(C)SC(=O)N(C)CCN(C)C(=O)OC(C)(C)C</smiles>

$633 \mathrm{mg}, 78 \%$ yield; semisolid; ${ }^{1} \mathrm{H}$ NMR (400 MHz, DMSO, $\left.24{ }^{\circ} \mathrm{C}\right) \delta 8.30(\mathrm{~d}, J=8.6 \mathrm{~Hz}, 1 \mathrm{H})$, 4.49 (d, $J=8.6 \mathrm{~Hz}, 1 \mathrm{H}), 3.63$ (s, 3H), 3.54 (s, 2H), 3.37 (s, 2H), 3.06 (s, 1.6H), 2.95 (s, 1.4H), $2.80(\mathrm{~s}, 1.4 \mathrm{H}), 2.74(\mathrm{~s}, 1.6 \mathrm{H}), 1.89(\mathrm{~s}, 3 \mathrm{H}), 1.37(\mathrm{~s}, 9 \mathrm{H}), 1.25(\mathrm{~s}, 6 \mathrm{H}) ;{ }^{13} \mathrm{C} \mathrm{NMR}(101 \mathrm{MHz}$, DMSO, $\left.24{ }^{\circ} \mathrm{C}\right) \delta 170.2,169.5,164.3,164.0,154.9,154.5,78.5,58.2,51.8,47.9,47.6,47.1$, 46.1, 45.5, 44.6, 35.8, 35.5, 35.0, 34.7, 34.3, 33.9, 33.6, 24.5, 23.7, 23.5, 22.2; ${ }^{1} \mathrm{H}$ NMR (400 MHz, DMSO, $\left.80{ }^{\circ} \mathrm{C}\right) \delta 7.98(\mathrm{~d}, J=8.7 \mathrm{~Hz}, 1 \mathrm{H}), 4.54(\mathrm{~d}, J=8.7 \mathrm{~Hz}, 1 \mathrm{H}), 3.66(\mathrm{~s}, 3 \mathrm{H}), 3.55(\mathrm{t}, J$ $=6.0 \mathrm{~Hz}, 2 \mathrm{H}), 3.38(\mathrm{t}, J=6.0 \mathrm{~Hz}, 2 \mathrm{H}), 3.02(\mathrm{~s}, 3 \mathrm{H}), 2.81(\mathrm{~s}, 3 \mathrm{H}), 1.92(\mathrm{~s}, 3 \mathrm{H}), 1.41(\mathrm{~s}, 9 \mathrm{H}), 1.32$ (s, 3H), $1.30(\mathrm{~s}, 3 \mathrm{H}) ;{ }^{13} \mathrm{C}$ NMR (101 MHz, DMSO, $\left.80{ }^{\circ} \mathrm{C}\right) \delta 169.6,169.0,164.2,154.4,78.4$, 58.3, 51.6, 51.1, 47.5, 45.4, 35.0, 33.9, 27.7, 24.4, 23.8, 21.8; HRMS (ESI): m/z calcd. for $\mathrm{C}_{18} \mathrm{H}_{33} \mathrm{~N}_{3} \mathrm{O}_{6} \mathrm{~S}_{2} \mathrm{Na}^{+}[\mathrm{M}+\mathrm{Na}]^{+} 474.1703$, found 474.1713 .

Methyl 13-acetamido-2,2,8,12,12-pentamethyl-4,9-dioxo-3-oxa-10,11-dithia-5,8diazatetradecan-14-oate (S1b)<smiles>COC(=O)C(NC(C)=O)C(C)(C)SC(=O)N(C)CCNC(=O)OC(C)(C)C</smiles>

$614 \mathrm{mg}, 78 \%$ yield; semisolid; ${ }^{1} \mathrm{H}$ NMR (400 MHz, DMSO, $\left.24{ }^{\circ} \mathrm{C}\right) \delta 8.31(\mathrm{~d}, J=8.5 \mathrm{~Hz}, 1 \mathrm{H})$, $7.02(\mathrm{~s}, 0.5 \mathrm{H}), 6.85(\mathrm{~s}, 0.5 \mathrm{H}), 4.50(\mathrm{~d}, J=8.5 \mathrm{~Hz}, 1 \mathrm{H}), 3.63(\mathrm{~s}, 3 \mathrm{H}), 3.45-3.40(\mathrm{~m}, 2 \mathrm{H}), 3.12$ $2.93(\mathrm{~m}, 5 \mathrm{H}), 1.89(\mathrm{~s}, 3 \mathrm{H}), 1.36(\mathrm{~s}, 9 \mathrm{H}), 1.26(\mathrm{~s}, 6 \mathrm{H}) ;{ }^{13} \mathrm{C}$ NMR $\left(101 \mathrm{MHz}, \mathrm{DMSO}, 24{ }^{\circ} \mathrm{C}\right) \delta 170.3$, $169.5,164.5,164.3,155.6,77.8,77.7,58.3,58.2,51.8,49.7,49.5,37.6,37.4,35.5,35.2,28.2$, 24.5, 23.8, 23.7, 22.2; ${ }^{1} \mathrm{H}$ NMR (400 MHz, DMSO, $\left.80{ }^{\circ} \mathrm{C}\right) \delta 7.99(\mathrm{~d}, J=8.4 \mathrm{~Hz}, 1 \mathrm{H}), 6.55(\mathrm{~s}, 1 \mathrm{H})$, $4.54(\mathrm{~d}, J=8.7 \mathrm{~Hz}, 1 \mathrm{H}), 3.66(\mathrm{~s}, 3 \mathrm{H}), 3.46(\mathrm{t}, J=6.1 \mathrm{~Hz}, 2 \mathrm{H}), 3.14(\mathrm{q}, J=6.1 \mathrm{~Hz}, 2 \mathrm{H}), 3.03(\mathrm{~s}$, $3 \mathrm{H}), 1.92(\mathrm{~s}, 3 \mathrm{H}), 1.39(\mathrm{~s}, 9 \mathrm{H}), 1.32(\mathrm{~s}, 3 \mathrm{H}), 1.31(\mathrm{~s}, 3 \mathrm{H}) ;{ }^{13} \mathrm{C}$ NMR $\left(101 \mathrm{MHz}, \mathrm{DMSO}, 80{ }^{\circ} \mathrm{C}\right) \delta$ 169.6, 169.0, 164.4, 155.1, 77.5, 58.4, 51.6, 51.1, 49.4, 37.6, 35.1, 27.8, 24.5, 23.9, 21.8; HRMS (ESI): $\mathrm{m} / \mathrm{z}$ calcd. for $\mathrm{C}_{17} \mathrm{H}_{31} \mathrm{~N}_{3} \mathrm{O}_{6} \mathrm{~S}_{2} \mathrm{Na}^{+}[\mathrm{M}+\mathrm{Na}]^{+} 460.1546$, found 460.1550 .

Methyl 14-acetamido-2,2,5,9,13,13-hexamethyl-4,10-dioxo-3-oxa-11,12-dithia-5,9diazapentadecan-15-oate (S1c)<smiles>COC(=O)C(NC(C)=O)C(C)(C)SSC(=O)N(C)CCCN(C)C(=O)OC(C)(C)C</smiles>

$360 \mathrm{mg}, 58 \%$ yield; semisolid; ${ }^{1} \mathrm{H}$ NMR (400 MHz, DMSO, $\left.24{ }^{\circ} \mathrm{C}\right) \delta 8.30(\mathrm{~d}, J=8.7 \mathrm{~Hz}, 1 \mathrm{H})$, $4.51(\mathrm{~d}, J=8.7 \mathrm{~Hz}, 1 \mathrm{H}), 3.63(\mathrm{~s}, 3 \mathrm{H}), 3.43-3.37(\mathrm{~m}, 2 \mathrm{H}), 3.19-2.94(\mathrm{~m}, 5 \mathrm{H}), 2.77(\mathrm{~s}, 3 \mathrm{H}), 1.89$ $(\mathrm{s}, 3 \mathrm{H}), 1.77-1.69(\mathrm{~m}, 2 \mathrm{H}), 1.39(\mathrm{~s}, 9 \mathrm{H}), 1.26(\mathrm{~s}, 6 \mathrm{H}) ;{ }^{13} \mathrm{C}$ NMR $\left(101 \mathrm{MHz}, \mathrm{DMSO}, 24{ }^{\circ} \mathrm{C}\right) \delta$ 170.2 , 169.5, 164.1, 163.6, 154.6, 78.4, 58.1, 47.8, 47.3, 45.9, 45.2, 35.4, 34.7, 33.7, 28.0, 26.2, 
25.3, 24.5, 23.6, 22.2; ${ }^{1} \mathrm{H}$ NMR (400 MHz, DMSO, $\left.80{ }^{\circ} \mathrm{C}\right) \delta 7.98(\mathrm{~d}, J=8.7 \mathrm{~Hz}, 1 \mathrm{H}), 4.55(\mathrm{~d}, J=$ $8.7 \mathrm{~Hz}, 1 \mathrm{H}), 3.66(\mathrm{~s}, 3 \mathrm{H}), 3.40(\mathrm{t}, J=7.2 \mathrm{~Hz}, 2 \mathrm{H}), 3.19$ (t, $J=7.2 \mathrm{~Hz}, 2 \mathrm{H}), 3.03(\mathrm{~s}, 3 \mathrm{H}), 2.80$ (s, $3 \mathrm{H}), 1.92(\mathrm{~s}, 3 \mathrm{H}), 1.78$ (quintet, $J=7.2 \mathrm{~Hz}, 2 \mathrm{H}), 1.42(\mathrm{~s}, 9 \mathrm{H}), 1.32(\mathrm{~s}, 3 \mathrm{H}), 1.30(\mathrm{~s}, 3 \mathrm{H}) ;{ }^{13} \mathrm{C}$ NMR $\left(101 \mathrm{MHz}, \mathrm{DMSO}, 80^{\circ} \mathrm{C}\right) \delta 169.6,169.0,163.9,154.4,78.1,58.2,51.6,51.1,47.4,45.5,34.6$, 33.4, 27.7, 25.4, 24.4, 23.8, 21.8; HRMS (ESI): $\mathrm{m} / \mathrm{z}$ calcd. for $\mathrm{C}_{19} \mathrm{H}_{36} \mathrm{~N}_{3} \mathrm{O}_{6} \mathrm{~S}_{2}{ }^{+}[\mathrm{M}+\mathrm{H}]^{+} 466.2040$, found 466.2041 .

Methyl 14-acetamido-2,2,9,13,13-pentamethyl-4,10-dioxo-3-oxa-11,12-dithia-5,9diazapentadecan-15-oate (S1d)

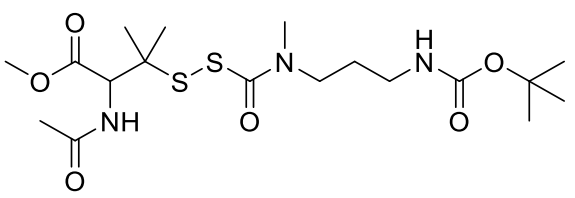

816 mg, 77\% yield; semisolid; S1d; ${ }^{1} \mathrm{H}$ NMR (400 MHz, DMSO, $\left.24{ }^{\circ} \mathrm{C}\right) \delta 8.31(\mathrm{~d}, \mathrm{~J}=8.7 \mathrm{~Hz}$, $1 \mathrm{H}), 6.90(\mathrm{~s}, 0.5 \mathrm{H}), 6.76(\mathrm{~s}, 0.5 \mathrm{H}), 4.50(\mathrm{~d}, J=8.7 \mathrm{~Hz}, 1 \mathrm{H}), 3.64(\mathrm{~s}, 3 \mathrm{H}), 3.40(\mathrm{bs}, 2 \mathrm{H}), 3.04-$ $2.90(\mathrm{~m}, 5 \mathrm{H}), 1.89$ (s, 3H), $1.73-1.53(\mathrm{~m}, 2 \mathrm{H}), 1.37(\mathrm{~s}, 9 \mathrm{H}), 1.26(\mathrm{~s}, 6 \mathrm{H}) ;{ }^{13} \mathrm{C} \mathrm{NMR}(101 \mathrm{MHz}$, DMSO, $\left.24^{\circ} \mathrm{C}\right) \delta 170.2,169.5,164.1,163.8,155.6,77.5,58.2,54.9,47.9,47.4,37.4,35.4,34.8$, 28.3, 27.2, 24.5, 23.6, 22.2; ${ }^{1} \mathrm{H}$ NMR (400 MHz, DMSO, $\left.80{ }^{\circ} \mathrm{C}\right) \delta 8.00(\mathrm{~d}, J=8.6 \mathrm{~Hz}, 1 \mathrm{H}), 6.46$ $(\mathrm{s}, 1 \mathrm{H}), 4.54(\mathrm{~d}, J=8.7 \mathrm{~Hz}, 1 \mathrm{H}), 3.66(\mathrm{~s}, 3 \mathrm{H}), 3.41(\mathrm{t}, J=7.2 \mathrm{~Hz}, 2 \mathrm{H}), 3.01(\mathrm{~s}, 3 \mathrm{H}), 2.96(\mathrm{q}, J=$ $7.2 \mathrm{~Hz}, 2 \mathrm{H}), 1.92$ (s, 3H), 1.70 (quintet, $J=7.2 \mathrm{~Hz}, 2 \mathrm{H}), 1.40(\mathrm{~s}, 9 \mathrm{H}), 1.31$ (s, 3H), 1.30 (s, 3H); ${ }^{13} \mathrm{C}$ NMR $\left(101 \mathrm{MHz}, \mathrm{DMSO}, 80{ }^{\circ} \mathrm{C}\right) \delta 169.6,169.0,164.0,155.2,77.2,58.3,51.6,51.2,47.5$, 37.4, 34.7, 27.9, 27.4, 24.4, 23.8, 21.8; HRMS (ESI): m/z calcd. for $\mathrm{C}_{18} \mathrm{H}_{33} \mathrm{~N}_{3} \mathrm{O}_{6} \mathrm{~S}_{2} \mathrm{Na}^{+}[\mathrm{M}+\mathrm{Na}]^{+}$ 474.1703, found 474.1714 .

\section{General procedure for synthesis of $7 \mathrm{a}-\mathrm{d}$}

$N$-Boc protected compounds S1a-d $(1 \mathrm{mmol})$ were dissolved in a 1:1 mixture of dichloromethane and trifluoroacetic acid $(4 \mathrm{~mL})$. The resulting solution was stirred at room temperature for $1 \mathrm{~h}$, and volatiles were removed under reduced pressure. The dichloromethane was successively added and evaporated to remove the residual TFA and obtain the desired RSSH/COS precursor.

2-((3-acetamido-4-methoxy-2-methyl-4-oxobutan-2-yl)disulfannecarbonyl)(methyl)amino)N-methylethan-1-aminium (7a)<smiles>COC(=O)C(NC(C)=O)C(C)(C)SSC(=O)N(C)CCNC(F)(F)F</smiles>

405 mg, 96 \% yield; semisolid; ${ }^{1} \mathrm{H}$ NMR (400 MHz, $\left.\mathrm{CDCl}_{3}\right) \delta 9.02$ (bs, 1H), 8.46 (bs, 1H), 7.85 $(\mathrm{d}, J=9.3 \mathrm{~Hz}, 1 \mathrm{H}), 4.63(\mathrm{~d}, J=9.3 \mathrm{~Hz}, 1 \mathrm{H}), 4.13-4.10(\mathrm{~m}, 1 \mathrm{H}), 3.74(\mathrm{~s}, 3 \mathrm{H}), 3.55-3.51(\mathrm{~m}$, $1 \mathrm{H}), 3.36(\mathrm{~s}, 2 \mathrm{H}), 3.13(\mathrm{~s}, 3 \mathrm{H}), 2.79(\mathrm{~s}, 3 \mathrm{H}), 2.14(\mathrm{~s}, 3 \mathrm{H}), 1.50(\mathrm{~s}, 3 \mathrm{H}), 1.35(\mathrm{~s}, 3 \mathrm{H}) ;{ }^{13} \mathrm{C} \mathrm{NMR}$ $\left(101 \mathrm{MHz} \mathrm{CDCl}_{3}\right) \delta 171.7,171.2,169.4,161.1$ (q, $\left.J=37.5 \mathrm{~Hz}\right), 116.0$ (q, $\left.J=289.9 \mathrm{~Hz}\right), 58.6$, 53.1, 52.5, 47.4, 47.2, 35.8, 33.6, 27.1, 25.7, 22.7; HRMS (ESI): m/z calcd. for $\mathrm{C}_{13} \mathrm{H}_{26} \mathrm{~N}_{3} \mathrm{O}_{4} \mathrm{~S}_{2}{ }^{+}$ $[\mathrm{M}]^{+} 352.1359$, found 352.1367 . 
2-(((3-acetamido-4-methoxy-2-methyl-4-oxobutan-2-

yl)disulfannecarbonyl)(methyl)amino)ethan-1-aminium (7b)

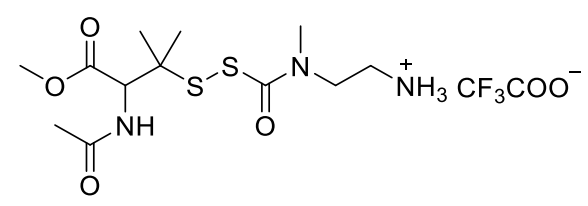

$485 \mathrm{mg}, 97 \%$ yield; semisolid; ${ }^{1} \mathrm{H}$ NMR $\left(400 \mathrm{MHz}, \mathrm{CDCl}_{3}\right) \delta 8.40(\mathrm{~s}, 3 \mathrm{H}), 8.19(\mathrm{~d}, J=9.3 \mathrm{~Hz}$, $1 \mathrm{H}), 4.61(\mathrm{~d}, J=9.5 \mathrm{~Hz}, 2 \mathrm{H}), 3.75(\mathrm{~s}, 3 \mathrm{H}), 3.38-3.16(\mathrm{~m}, 6 \mathrm{H}), 1.97(\mathrm{~s}, 3 \mathrm{H}), 1.42(\mathrm{~s}, 3 \mathrm{H}), 1.29$ (s, $3 \mathrm{H}) ;{ }^{13} \mathrm{C}$ NMR $\left(101 \mathrm{MHz}, \mathrm{CDCl}_{3}\right) \delta 172.2,172.1,170.9,160.9$ (q, $\left.J=37.3 \mathrm{~Hz}\right), 116.1$ (q, $J=$ $289.9 \mathrm{~Hz}$ ), 59.2, 52.7, 52.6, 48.3, 38.1, 35.3, 27.0, 26.8, 22.3; HRMS (ESI): $\mathrm{m} / \mathrm{z}$ calcd. for $\mathrm{C}_{12} \mathrm{H}_{24} \mathrm{~N}_{3} \mathrm{O}_{4} \mathrm{~S}_{2}{ }^{+}[\mathrm{M}]^{+}$338.1203, found 338.1199.

3-(((3-acetamido-4-methoxy-2-methyl-4-oxobutan-2-yl)disulfannecarbonyl)(methyl)amino)N-methylpropan-1-aminium (7c)<smiles>COC(=O)C(NC(C)=O)C(C)(C)SSC(=O)N(C)CCCNC(F)(F)F</smiles>

290 mg, 94\% yield; semisolid; ${ }^{1} \mathrm{H}$ NMR (400 MHz, DMSO) $\delta 8.47$ (bs, 2H), 8.33 (d, $J=8.7 \mathrm{~Hz}$, $1 \mathrm{H}), 4.52(\mathrm{~d}, J=8.7 \mathrm{~Hz}, 1 \mathrm{H}), 3.64(\mathrm{~s}, 3 \mathrm{H}), 3.49-3.44(\mathrm{~m}, 2 \mathrm{H}), 3.07-2.84(\mathrm{~m}, 5 \mathrm{H}), 2.56(\mathrm{~s}$, $3 \mathrm{H}), 1.90$ (s, 3H), $1.84-1.78(\mathrm{~m}, 2 \mathrm{H}), 1.27(\mathrm{~s}, 3 \mathrm{H}), 1.27(\mathrm{~s}, 3 \mathrm{H}) ;{ }^{13} \mathrm{C} \mathrm{NMR}\left(101 \mathrm{MHz}, \mathrm{CDCl}_{3}\right) \delta$ 170.9, 170.4, 168.0, 161.9 (q, $J=37.5 \mathrm{~Hz}), 116.6$ (q, $J=291.4 \mathrm{~Hz}), 59.0,52.7,52.2,47.6,46.8$, 35.1, 33.2, 26.5, 25.7, 24.0, 22.8; HRMS (ESI): $\mathrm{m} / \mathrm{z}$ calcd. for $\mathrm{C}_{14} \mathrm{H}_{28} \mathrm{~N}_{3} \mathrm{O}_{4} \mathrm{~S}_{2}{ }^{+}[\mathrm{M}]^{+} 366.1516$, found 366.1515 .

3-(((3-acetamido-4-methoxy-2-methyl-4-oxobutan-2yl)disulfannecarbonyl)(methyl)amino)propan-1-aminium (7d)<smiles></smiles>

$540 \mathrm{mg}, 96 \%$ yield, semisolid; ${ }^{1} \mathrm{H}$ NMR (400 MHz, $\left.\mathrm{CDCl}_{3}\right) \delta 7.91$ (bs, 3H), 7.57 (d, J=8.4 Hz, $1 \mathrm{H}), 4.53(\mathrm{~d}, J=8.4 \mathrm{~Hz}, 1 \mathrm{H}), 3.73(\mathrm{~s}, 3 \mathrm{H}), 3.66-3.46(\mathrm{~m}, 2 \mathrm{H}), 3.11(\mathrm{~s}, 3 \mathrm{H}), 3.04(\mathrm{~s}, 2 \mathrm{H}), 2.08$ $(\mathrm{s}, 3 \mathrm{H}), 2.06-1.94(\mathrm{~m}, 2 \mathrm{H}), 1.43(\mathrm{~s}, 3 \mathrm{H}), 1.33(\mathrm{~s}, 3 \mathrm{H}) ;{ }^{13} \mathrm{C} \mathrm{NMR}\left(101 \mathrm{MHz}, \mathrm{CDCl}_{3}\right) \delta 171.5$, $170.5,168.5,161.5$ (q, $J=37.1 \mathrm{~Hz}$ ), 116.4 (q, $J=289.6 \mathrm{~Hz}$ ), 59.2, 52.7, 52.3, 47.5, 37.2, 35.2, 26.3, 25.4, 25.1, 22.6; HRMS (ESI): $\mathrm{m} / \mathrm{z}$ calcd. for $\mathrm{C}_{13} \mathrm{H}_{26} \mathrm{~N}_{3} \mathrm{O}_{4} \mathrm{~S}_{2}{ }^{+}[\mathrm{M}]^{+} 352.1359$, found 352.1364 . 
Methyl 2-acetamido-3-methyl-3-((methyl(propyl)carbamoyl)disulfaneyl)butanoate (8)<smiles>CCCN(C)C(=O)SC(C)(C)C(N)C(=O)OC</smiles>

$479 \mathrm{mg}, 58 \%$ yield; mixture of rotamers; ${ }^{1} \mathrm{H}$ NMR (400 MHz, DMSO, $\left.24{ }^{\circ} \mathrm{C}\right) \delta 8.31(\mathrm{~d}, J=8.7$ $\mathrm{Hz}, 1 \mathrm{H}), 4.51$ (d, J=8.7 Hz, 1H), 3.64 (s, 3H), 3.40 (bs, 2H), 3.04 (s, 1.5H), 2.93 (s, 1.5H), 1.89 $(\mathrm{s}, 3 \mathrm{H}), 1.59-1.51(\mathrm{~m}, 2 \mathrm{H}), 1.26(\mathrm{~s}, 6 \mathrm{H}), 0.84(3 \mathrm{H}) ;{ }^{13} \mathrm{C} \mathrm{NMR}\left(101 \mathrm{MHz}, \mathrm{DMSO}, 24{ }^{\circ} \mathrm{C}\right) \delta$ 170.2 , 169.5, 163.9, 163.7, 58.1, 51.8, 51.7, 51.5, 51.0, 35.3, 34.6, 24.4, 23.6, 22.2, 20.8, 19.9, 10.8; ${ }^{1} \mathrm{H}$ NMR (400 MHz, DMSO, $\left.70{ }^{\circ} \mathrm{C}\right) \delta 8.07(\mathrm{~d}, J=8.7 \mathrm{~Hz}, 1 \mathrm{H}), 4.54(\mathrm{~d}, J=8.7 \mathrm{~Hz}, 1 \mathrm{H})$, $3.65(\mathrm{~s}, 3 \mathrm{H}), 3.37$ (t, $J=7.2 \mathrm{~Hz}, 2 \mathrm{H}), 3.00(\mathrm{~s}, 3 \mathrm{H}), 1.91(\mathrm{~s}, 3 \mathrm{H}), 1.58$ (sextet, $J=7.2 \mathrm{~Hz}, 2 \mathrm{H})$, $1.30(\mathrm{~s}, 3 \mathrm{H}), 1.29(\mathrm{~s}, 3 \mathrm{H}), 0.87(\mathrm{t}, J=7.2 \mathrm{~Hz}, 3 \mathrm{H}) ;{ }^{13} \mathrm{C}$ NMR $\left(101 \mathrm{MHz}, \mathrm{DMSO}, 70{ }^{\circ} \mathrm{C}\right) \delta 169.8$, 169.1, 163.9, 58.2, 51.6, 51.3, 51.1, 34.7, 24.3, 23.7, 21.9, 20.1, 10.4; HRMS (ESI): m/z calcd. for $\mathrm{C}_{13} \mathrm{H}_{25} \mathrm{~N}_{2} \mathrm{O}_{2} \mathrm{~S}_{2}{ }^{+}[\mathrm{M}+\mathrm{H}]^{+} 337.1250$, found 337.1260.

\section{Scheme S2. Synthesis of RSS-HPE-AM 9}
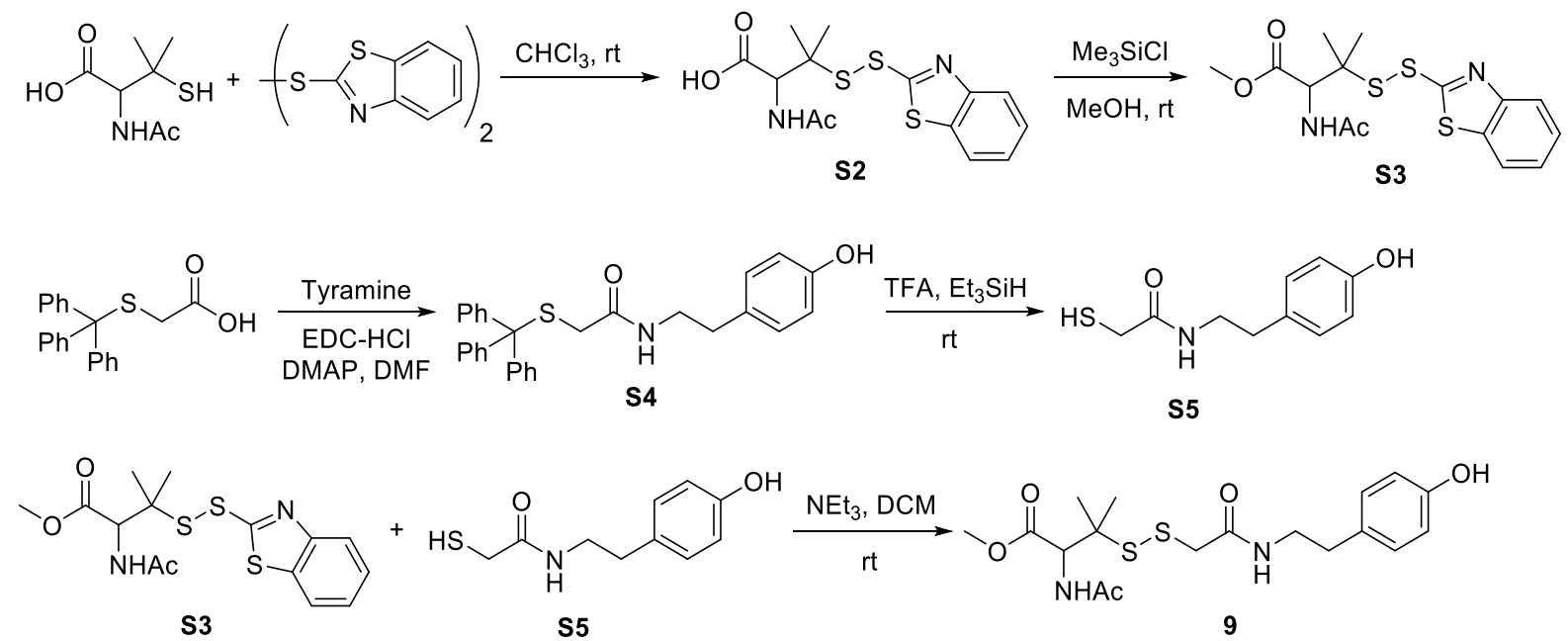

2-Acetamido-3-(benzothiazol-2-yldisulfaneyl)-3-methylbutanoic acid (S2)<smiles>CC(=O)NC(C(=O)O)C(C)(C)Sc1nc2ccccc2s1</smiles>

2, 2'-Dibenzothiazolyl disulfide (2.61 g, $7.84 \mathrm{mmol})$ was dissolved in $\mathrm{CHCl}_{3}(100 \mathrm{~mL})$. To this solution, $N$-acetyl- $D$-penicillamine $(1 \mathrm{~g}, 5.23 \mathrm{mmol})$ was added. The reaction mixture was stirred at room temperature for $16 \mathrm{~h}$. The solvent was removed under reduced pressure, and the residue was purified by flash column chromatography on silica gel (5\% MeOH in DCM) to obtain $\mathbf{S 2}$ (1.49 g, 80\% yield) as a white solid; ${ }^{1} \mathrm{H}$ NMR (400 MHz, DMSO) $\delta 13.13(\mathrm{~s}, 1 \mathrm{H}), 8.39(\mathrm{~d}, J=9.3 \mathrm{~Hz}$, $1 \mathrm{H}), 8.03(\mathrm{~d}, J=8.0 \mathrm{~Hz}, 1 \mathrm{H}), 7.84(\mathrm{~d}, J=8.0 \mathrm{~Hz}, 1 \mathrm{H}), 7.50-7.38(\mathrm{~m}, 2 \mathrm{H}), 4.64(\mathrm{~d}, J=9.2 \mathrm{~Hz}$, $1 \mathrm{H}), 1.92(\mathrm{~s}, 3 \mathrm{H}), 1.44(\mathrm{~s}, 3 \mathrm{H}), 1.41(\mathrm{~s}, 3 \mathrm{H}) ;{ }^{13} \mathrm{C}$ NMR $(101 \mathrm{MHz}, \mathrm{DMSO}) \delta 172.6,170.8,169.6$, 154.3, 135.2, 126.6, 125.0, 121.9, 121.8, 58.0, 54.6, 25.0, 23.4, 22.3; HRMS (ESI): $\mathrm{m} / \mathrm{z}$ calcd. for $\mathrm{C}_{14} \mathrm{H}_{17} \mathrm{~N}_{2} \mathrm{O}_{3} \mathrm{~S}_{3}{ }^{+}[\mathrm{M}+\mathrm{H}]^{+}$357.0396, found 357.0395. 
Methyl 2-acetamido-3-(benzo[d]thiazol-2-yldisulfaneyl)-3-methylbutanoate (S3)

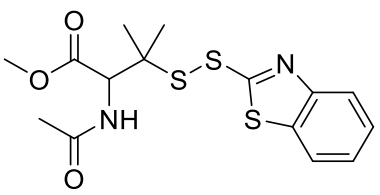

To a solution of $\mathbf{S 2}$ (1.46 g, $4.1 \mathrm{mmol})$ in anhydrous methanol (30 mL) under a nitrogen atmosphere, chlorotrimethylsilane $(1.33 \mathrm{~g}, 12.29 \mathrm{mmol})$ was added. The reaction mixture was stirred at room temperature for $16 \mathrm{~h}$, and volatiles were removed under vacuum. The residue was purified by flash column chromatography (silica gel, hexane/ethyl acetate 50:50) to afford the product $\mathbf{S 3}(0.97 \mathrm{~g}, 64 \%)$ as a semisolid; ${ }^{1} \mathrm{H} \mathrm{NMR}\left(400 \mathrm{MHz}, \mathrm{CDCl}_{3}\right) \delta 7.88(\mathrm{~d}, J=7.8 \mathrm{~Hz}, 1 \mathrm{H})$, $7.79(\mathrm{dd}, J=8.0,0.6 \mathrm{~Hz}, 1 \mathrm{H}), 7.47-7.42(\mathrm{~m}, 1 \mathrm{H}), 7.37-7.32(\mathrm{~m}, 1 \mathrm{H}), 6.57$ (d, $J=9.0 \mathrm{~Hz}, 1 \mathrm{H})$, $4.84(\mathrm{~d}, J=9.3 \mathrm{~Hz}, 1 \mathrm{H}), 3.76(\mathrm{~s}, 3 \mathrm{H}), 2.05(\mathrm{~s}, 3 \mathrm{H}), 1.53(\mathrm{~s}, 3 \mathrm{H}), 1.48(\mathrm{~s}, 3 \mathrm{H}):{ }^{13} \mathrm{C} \mathrm{NMR}(101 \mathrm{MHz}$, $\left.\mathrm{CDCl}_{3}\right) \delta 172.2,170.4,170.0,154.5,135.9,126.5,125.0,122.3,121.3,59.0,54.9,52.6,26.0,24.9$, 23.3; HRMS (ESI): $\mathrm{m} / \mathrm{z}$ calcd. for $\mathrm{C}_{15} \mathrm{H}_{19} \mathrm{~N}_{2} \mathrm{O}_{3} \mathrm{~S}_{3}{ }^{+}[\mathrm{M}+\mathrm{H}]^{+} 371.0552$, found 371.0560 .

\section{$N$-(4-Hydroxyphenethyl)-2-(tritylthio)acetamide (S4)}<smiles>O=C(CSc1ccccc1)NCCc1ccc(O)cc1</smiles>

To a solution of $S$-trityl 2-mercaptoacetic acid $(1.80 \mathrm{~g}, 5.38 \mathrm{mmol})$ in anhydrous DMF $(30 \mathrm{~mL})$ at $0{ }^{\circ} \mathrm{C}$, EDC-HCl (1.24 g, $\left.6.46 \mathrm{mmol}\right)$ and DMAP $(13 \mathrm{mg}, 0.1 \mathrm{mmol})$ were added. The mixture was stirred at $0{ }^{\circ} \mathrm{C}$ for $1 \mathrm{~h}$. Tyramine $(812 \mathrm{mg}, 5.92 \mathrm{mmol})$ was added to the reaction mixture and stirred at room temperature for overnight. The reaction mixture was quenched by the addition of $1 \mathrm{M} \mathrm{HCl}(50 \mathrm{~mL})$ and extracted with ethyl acetate $(3 \times 30 \mathrm{~mL})$. The combined organic layer was washed with brine, dried over $\mathrm{Na}_{2} \mathrm{SO}_{4}$, and the solvent was evaporated under vacuum. The residue was purified by flash column chromatography to afford the product $\mathbf{S 4}$ (1.45 g, 59\% yield) as a white solid; ${ }^{1} \mathrm{H}$ NMR (300 MHz, DMSO) $\delta 9.14(\mathrm{~s}, 1 \mathrm{H}), 7.87$ (t, $\left.J=5.2 \mathrm{~Hz}, 1 \mathrm{H}\right), 7.38-7.14(\mathrm{~m}$, $15 \mathrm{H}), 6.92$ (d, $J=8.2 \mathrm{~Hz}, 2 \mathrm{H}), 6.64(\mathrm{~d}, J=8.2 \mathrm{~Hz}, 2 \mathrm{H}), 3.14-3.03(\mathrm{~m}, 2 \mathrm{H}), 2.73(\mathrm{~s}, 2 \mathrm{H}), 2.54$ $(2 \mathrm{H}), \mathrm{CH}_{2}$ protons merged with a DMSO- $d_{6}$ peak; ${ }^{13} \mathrm{C}$ NMR (101 MHz, DMSO) $\delta 167.0,155.6$, 144.1, 129.4, 129.3, 129.1, 128.1, 126.8, 115.1, 65.9, 40.8, 36.0, 34.1; HRMS (ESI): m/z calcd. for $\mathrm{C}_{29} \mathrm{H}_{28} \mathrm{NO}_{2} \mathrm{SNa}^{+}[\mathrm{M}+\mathrm{Na}]^{+} 476.1655$, found 476.1649 .

\section{N-(4-Hydroxyphenethyl)-2-mercaptoacetamide (S5)}<smiles>O=C(CS)NCCc1ccc(O)cc1</smiles>

To a stirred solution of $\mathbf{S 4}(200 \mathrm{mg}, 0.4 \mathrm{mmol})$ in $\mathrm{CH}_{2} \mathrm{Cl}_{2}(10 \mathrm{ml})$ at $0{ }^{\circ} \mathrm{C}, \mathrm{Et}_{3} \mathrm{SiH}(107 \mu \mathrm{L}, 0.7$ $\mathrm{mmol})$, and $\mathrm{CF}_{3} \mathrm{COOH}(1 \mathrm{~mL})$ were added. The reaction mixture was warmed to room temperature, stirred for $1 \mathrm{~h}$ and volatiles were evaporated under vacuum. The residue was purified by flash chromatography (silica gel, eluent: 50\% ethyl acetate in hexane) to afford the product S5 (64 mg, 69\% yield) as a semisolid; ${ }^{1} \mathrm{H}$ NMR $\left(400 \mathrm{MHz}, \mathrm{CDCl}_{3}\right) \delta 7.06(\mathrm{~d}, J=8.4 \mathrm{~Hz}, 2 \mathrm{H}), 6.79$ $(\mathrm{d}, J=8.4 \mathrm{~Hz}, 2 \mathrm{H}), 6.71(\mathrm{~s}, 1 \mathrm{H}), 3.54-3.49(\mathrm{~m}, 2 \mathrm{H}), 3.21(\mathrm{~d}, J=9.1 \mathrm{~Hz}, 2 \mathrm{H}), 2.77(\mathrm{t}, J=7.0 \mathrm{~Hz}$, 2H), 1.77 (t, $J=9.1 \mathrm{~Hz}, 1 \mathrm{H}) ;{ }^{13} \mathrm{C} \mathrm{NMR}\left(101 \mathrm{MHz}, \mathrm{CDCl}_{3}\right) \delta 169.4,154.7,130.5,130.0,115.7$, 41.3, 34.7, 28.5; HRMS (ESI): $\mathrm{m} / \mathrm{z}$ calcd. for $\mathrm{C}_{10} \mathrm{H}_{14} \mathrm{NO}_{4} \mathrm{~S}^{+}[\mathrm{M}+\mathrm{H}]^{+} 212.0740$, found 212.0740 
Ethyl 2-acetamido-3-((2-((4-hydroxyphenethyl)amino)-2-oxoethyl)disulfaneyl)-3methylbutanoate (9)<smiles>COC(=O)C(NC(C)=O)C(C)(C)SSCC(=O)NCCc1ccc(O)cc1</smiles>

To a nitrogen-flushed solution of $\mathbf{S 5}$ (107 $\mathrm{mg}, 0.5 \mathrm{mmol})$ and activated disulfide $\mathbf{S 3}$ (225 mg, 0.6 $\mathrm{mmol})$ in dichloromethane $(10 \mathrm{~mL})$, triethylamine $(0.14 \mathrm{~mL}, 1.1 \mathrm{mmol})$ was added. The reaction mixture was stirred at room temperature for $2 \mathrm{~h}$. The mixture was quenched by the addition of $1 \mathrm{M}$ aqueous hydrochloric acid solution and extracted with dichloromethane. The organic layer was washed with brine, dried over $\mathrm{Na}_{2} \mathrm{SO}_{4}$, filtered, and the solvent was evaporated under vacuum. The crude product was purified by flash column chromatography to afford the product $9(0.18 \mathrm{~g}$, $86 \%$ yield) as a white solid; ${ }^{1} \mathrm{H} \mathrm{NMR}\left(400 \mathrm{MHz}, \mathrm{CDCl}_{3}\right) \delta 7.04(\mathrm{~d}, J=8.5 \mathrm{~Hz}, 2 \mathrm{H}), 6.79(\mathrm{~d}, J=$ $8.5 \mathrm{~Hz}, 2 \mathrm{H}), 6.59(\mathrm{~s}, 1 \mathrm{H}), 6.54(\mathrm{t}, J=5.6 \mathrm{~Hz}, 1 \mathrm{H}), 6.43(\mathrm{~d}, J=9.2 \mathrm{~Hz}, 1 \mathrm{H}), 4.73(\mathrm{~d}, J=9.2 \mathrm{~Hz}$, $1 \mathrm{H}), 3.74$ (s, 3H), 3.50 (q, $J=6.4 \mathrm{~Hz}, 2 \mathrm{H}), 3.46-3.32(\mathrm{~m}, 2 \mathrm{H}), 2.76(\mathrm{t}, J=6.9 \mathrm{~Hz}, 2 \mathrm{H}), 2.05$ (s, $3 \mathrm{H}), 1.38(\mathrm{~s}, 3 \mathrm{H}), 1.37(\mathrm{~s}, 3 \mathrm{H}) ;{ }^{13} \mathrm{C} \mathrm{NMR}\left(101 \mathrm{MHz}, \mathrm{CDCl}_{3}\right) \delta 170.9,170.6,168.7,155.3,129.9$, 129.8, 115.8, 58.8, 52.6, 52.6, 43.6, 41.5, 34.7, 26.0, 24.2, 23.2; HRMS (ESI): $\mathrm{m} / \mathrm{z}$ calcd. for $\mathrm{C}_{18} \mathrm{H}_{27} \mathrm{~N}_{2} \mathrm{O}_{5} \mathrm{~S}_{2}^{+}[\mathrm{M}+\mathrm{H}]^{+}$415.1356, found 415.1354. 


\section{RSSH release from precursor 1a analyzed by UPLC-MS}

Precursor 1a was dissolved in DMSO to afford a $1 \mathrm{mM}$ stock solution. Similarly, HPE-IAM and $\mathrm{N}$-ethyl maleimide (NEM) were independently dissolved in DMSO to obtain $50 \mathrm{mM}$ stock solutions. To a $20 \mathrm{~mL}$ scintillation vial, HPE-IAM or NEM $(30 \mu \mathrm{L}, 50 \mathrm{mM})$ was added in $\mathrm{pH} 7.4$ ammonium bicarbonate buffer $(2.94 \mathrm{~mL})$ containing the DTPA $(100 \mu \mathrm{M})$. The resulting solution was pre-incubated at $37{ }^{\circ} \mathrm{C}$ for $10 \mathrm{~min}$. Precursor $1 \mathrm{a}(30 \mu \mathrm{L}, 1 \mathrm{mM})$ was then added into the mixture and incubated for $15 \mathrm{~min}$ at $37^{\circ} \mathrm{C}$. An aliquot of the reaction mixture $(500 \mu \mathrm{L})$ was withdrawn, 4-hydroxyphenylacetamide $(10 \mu \mathrm{M})$ was added as internal standard, and analyzed using UPLC-MS as follows: Mobile phase: $0-1 \mathrm{~min} 90 \%$ water $+0 \% \mathrm{ACN}+10 \%$ formic acid $(0.1 \%) ; 1-7.5 \mathrm{~min}$ gradient up to $10 \%$ water $+80 \% \mathrm{ACN}+10 \%$ formic acid $(0.1 \%) ; 7.5-8.4 \mathrm{~min}$ $10 \%$ water $+80 \% \mathrm{ACN}+10 \%$ formic acid $(0.1 \%) ; 8.4-8.5$ min gradient up to $90 \%$ water $+0 \%$ $\mathrm{ACN}+10 \%$ formic acid $(0.1 \%), 8.5-10$ min $90 \%$ water $+0 \% \mathrm{ACN}+10 \%$ formic acid $(0.1 \%)$. Flow rate $=0.3 \mathrm{~mL} / \mathrm{min}$. To quantify the byproduct $\mathbf{2 a}$ generated from 1a, we generated a calibration curve with known concentrations of commercially available cyclic urea 2a. These studies were conducted at least in triplicate and representative spectra are presented.

\section{RSSH generation from precursor $1 \mathrm{a}$ in the presence of HPE-IAM}
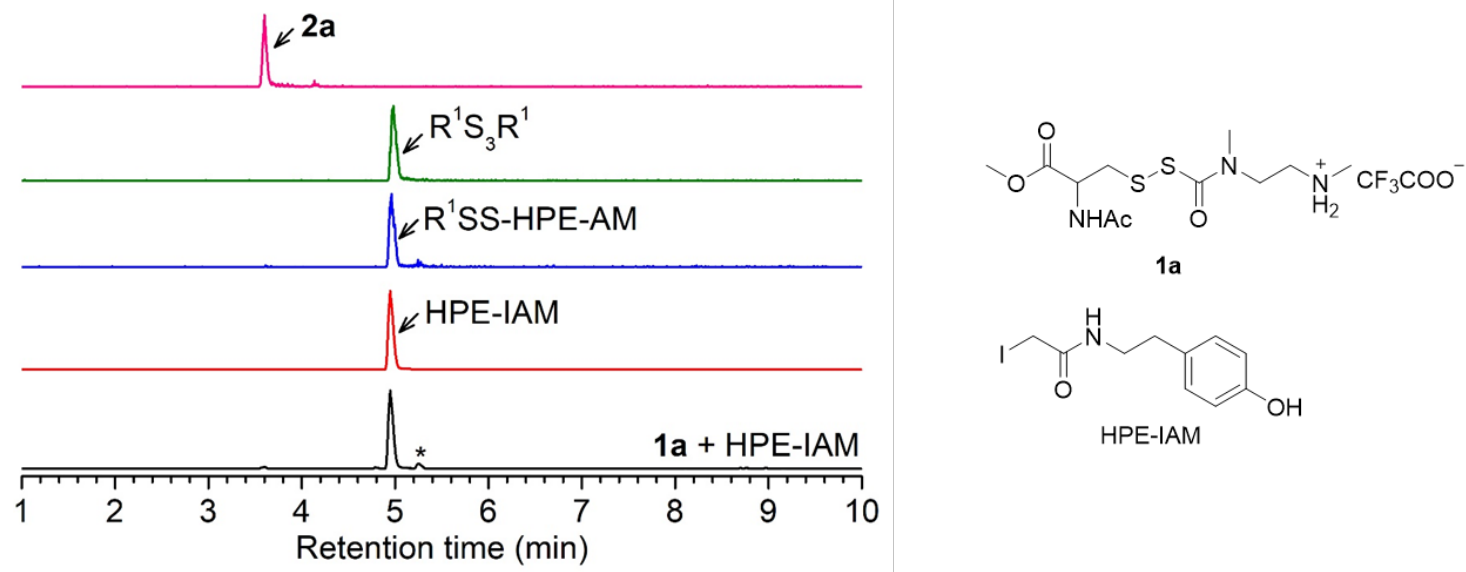

Figure S1. RSSH generation from 1a $(10 \mu \mathrm{M})$ in the presence of HPE-IAM $(500 \mu \mathrm{M})$ in pH 7.4 ammonium bicarbonate buffer at $37{ }^{\circ} \mathrm{C}$ for $15 \mathrm{~min}$ analyzed by UPLC-MS (bottom chromatogram). Under these conditions, $\mathrm{R}^{1} \mathrm{SS}-\mathrm{HPE}-\mathrm{AM} \mathbf{5}$, dialkyltrisulfide 6, and HPE-IAM coeluted. Hence, individual mass extracted chromatograms are shown separately. Also, the byproduct 2a and internal standard 4hydroxyphenylacetamide coeluted at $3.6 \mathrm{~min}$. Under these conditions, $5.2 \pm 0.2 \mu \mathrm{M}$ of $\mathbf{2 a}$ formation is observed. The asterisk indicates the presence of small amount of impurity in the commercial HPE-IAM sample. 


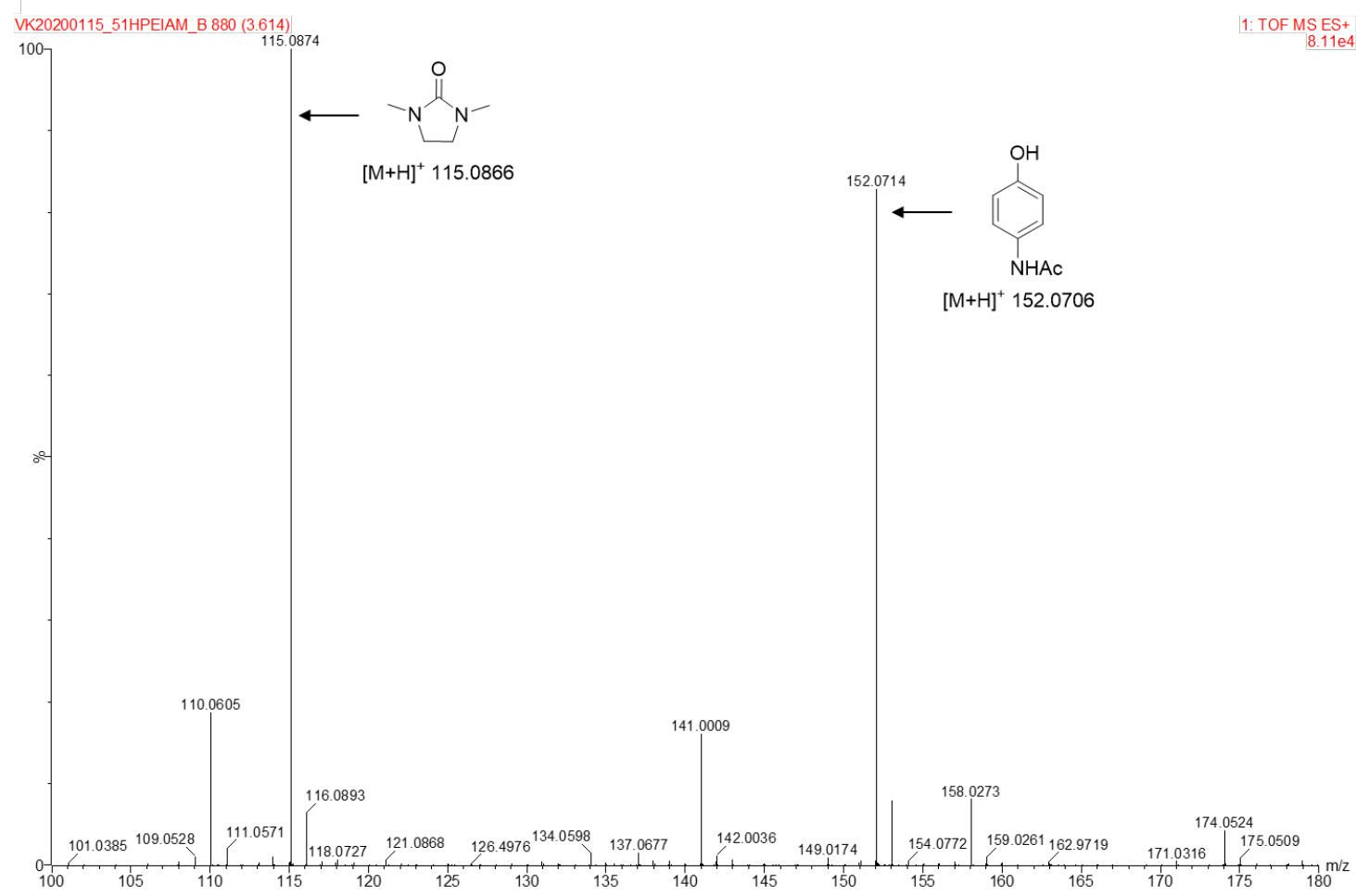

Figure S2. HRMS of the byproduct 2a coeluted with the internal standard 4-hydroxyphenylacetamide at $3.61 \mathrm{~min}$.

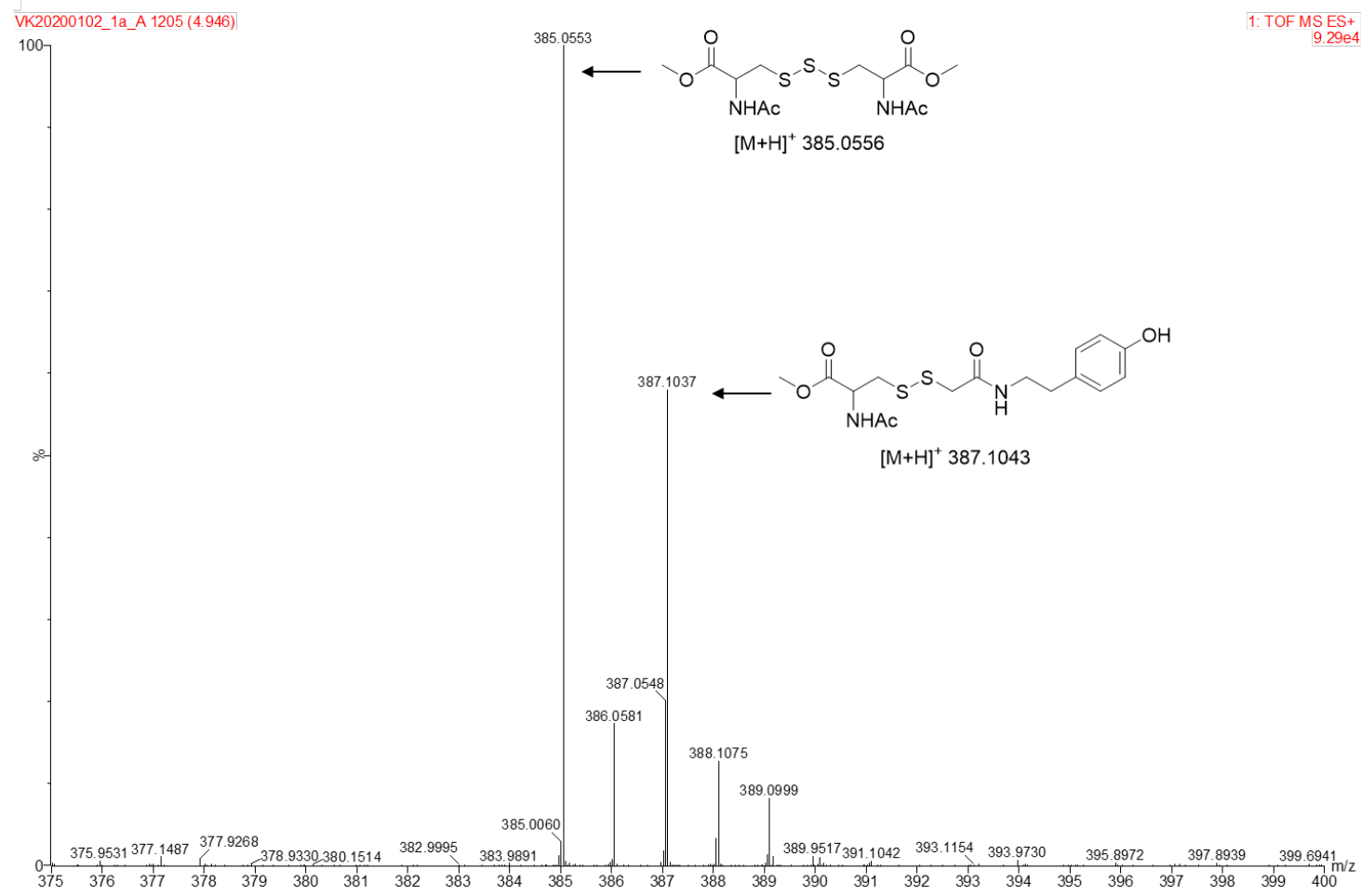

Figure S3. HRMS of the R ${ }^{1}$ SS-HPE-AM 5 and dialkyltrisulfide 6 coeluted with HPE-IAM at 4.95 min. 


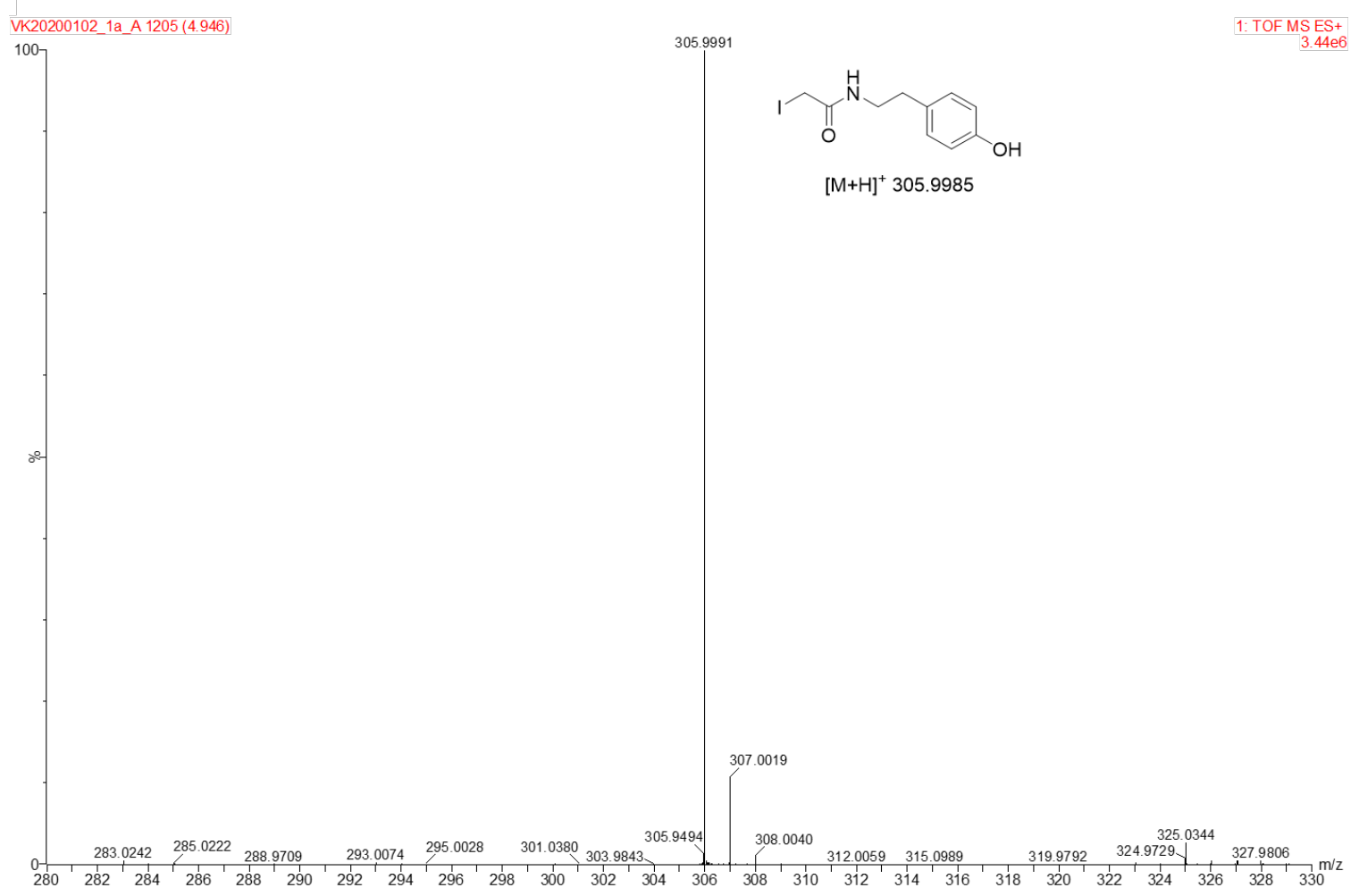

Figure S4. HRMS of the peak eluting at 4.95 min corresponding to HPE-IAM.

\section{RSSH generation from precursor $1 \mathrm{a}$ in the presence of $\mathrm{N}$-ethyl maleimide}

(a)

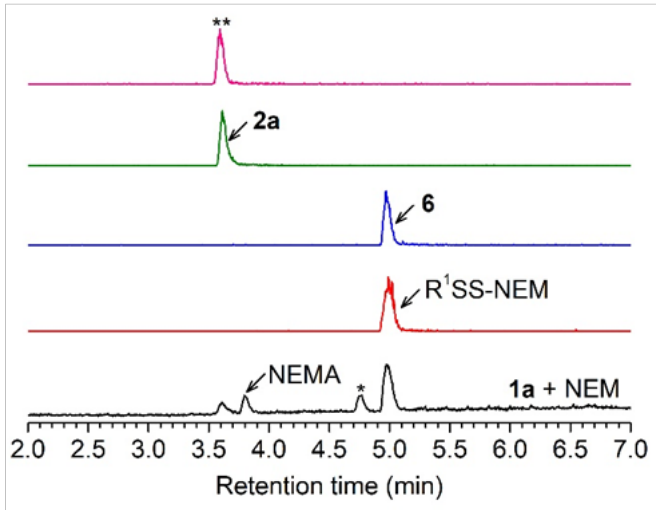

(b)

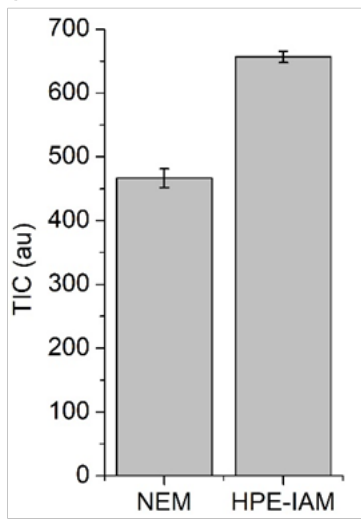

Figure S5. (a) RSSH generation from 1a $(10 \mu \mathrm{M})$ in the presence of NEM $(500 \mu \mathrm{M})$ in pH 7.4 ammonium bicarbonate buffer at $37{ }^{\circ} \mathrm{C}$ for 15 min analyzed by UPLC-MS (bottom chromatogram). ${ }^{1}$ SS-NEM and dialkyltrisulfide 6 coeluted; hence individual mass extracted chromatograms are shown separately. Also, the byproduct $\mathbf{2 a}$ and internal standard 4-hydroxyphenylacetamide (labeled as **) coeluted at 3.6 min. Under these conditions, $7.4 \pm 0.2 \mu \mathrm{M}$ of $2 \mathrm{a}$ formation is observed. A peak at 3.7 min corresponding to $\mathrm{N}$ ethylmaleamic acid (NEMA), derived from NEM hydrolysis, is observed. The asterisk represents a minor amount of thiol-NEM adduct formation, suggesting that excess NEM reacts with $\mathrm{R}^{1}$ SS-NEM adduct to produce $\mathrm{R}^{1} \mathrm{~S}-\mathrm{NEM}^{4}$ (b) Comparison of dialkyltrisulfide $\mathbf{6}$ formation from 1a in the presence of NEM and HPE-IAM under similar conditions. 


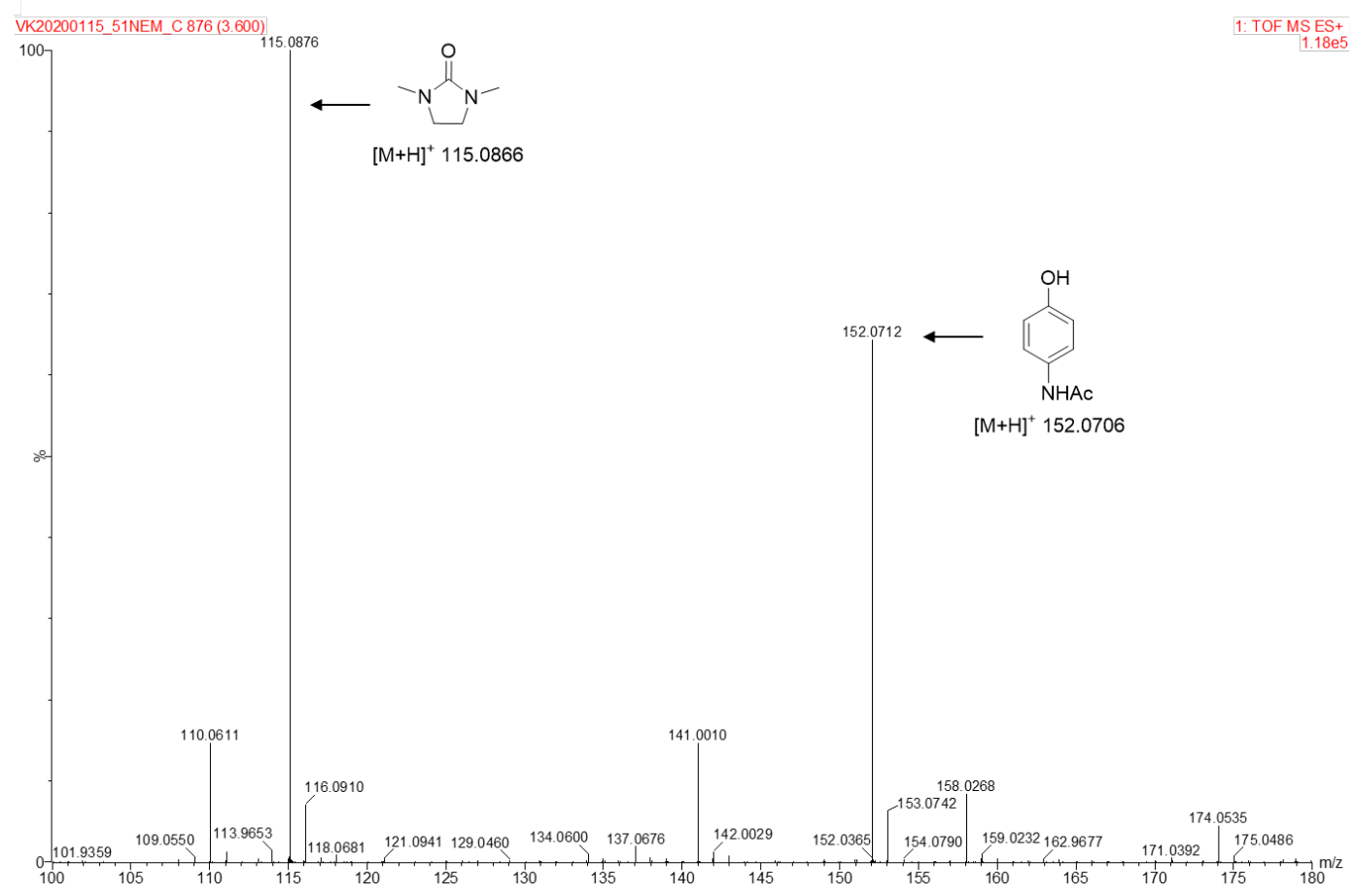

Figure S6. HRMS of the byproduct 2a coeluted with internal standard 4-hydroxyphenylacetamide at $3.6 \mathrm{~min}$.

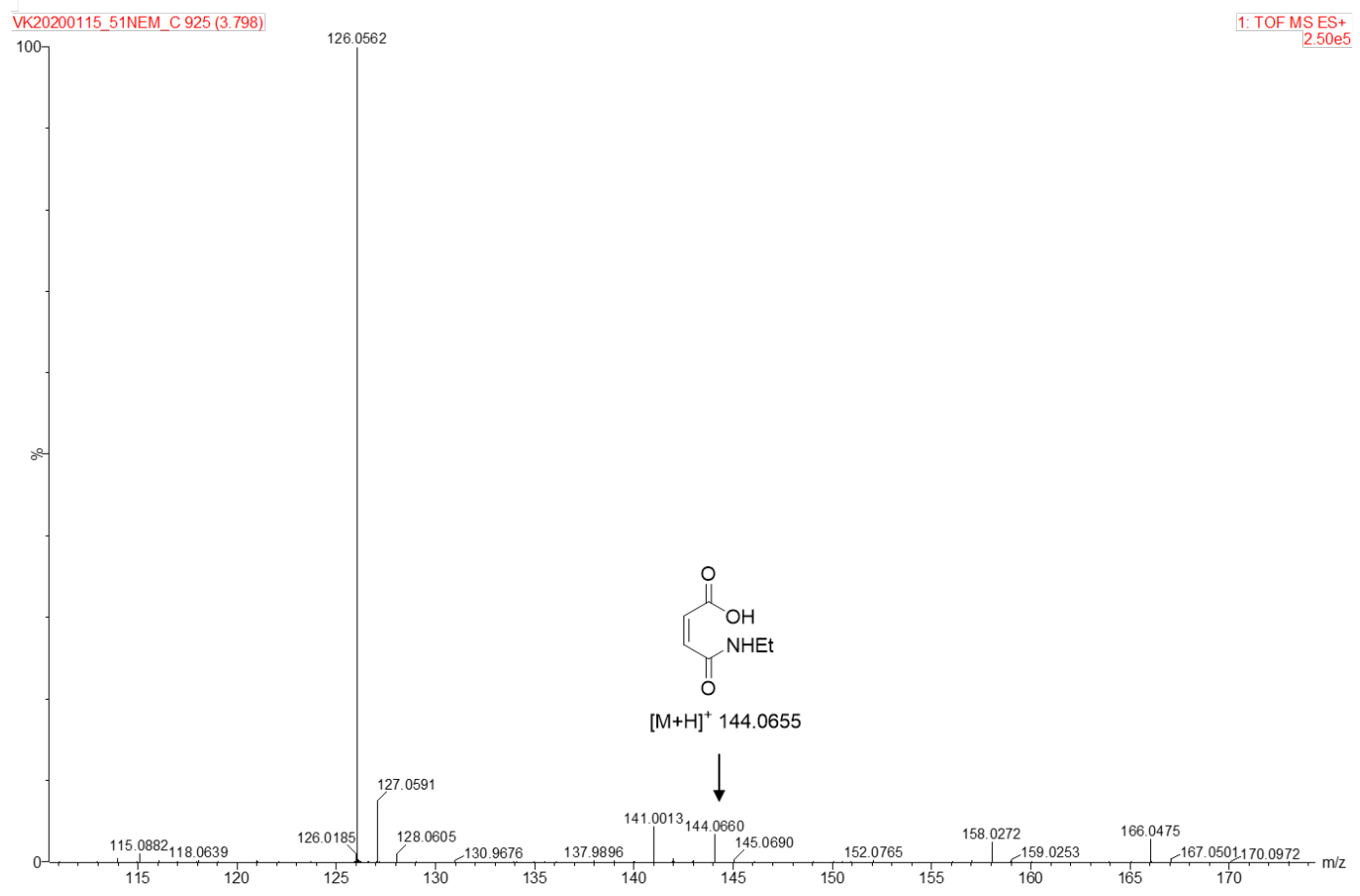

Figure S7. HRMS of the peak eluting at 3.80 min corresponding to $N$-ethyl maleamic acid. 


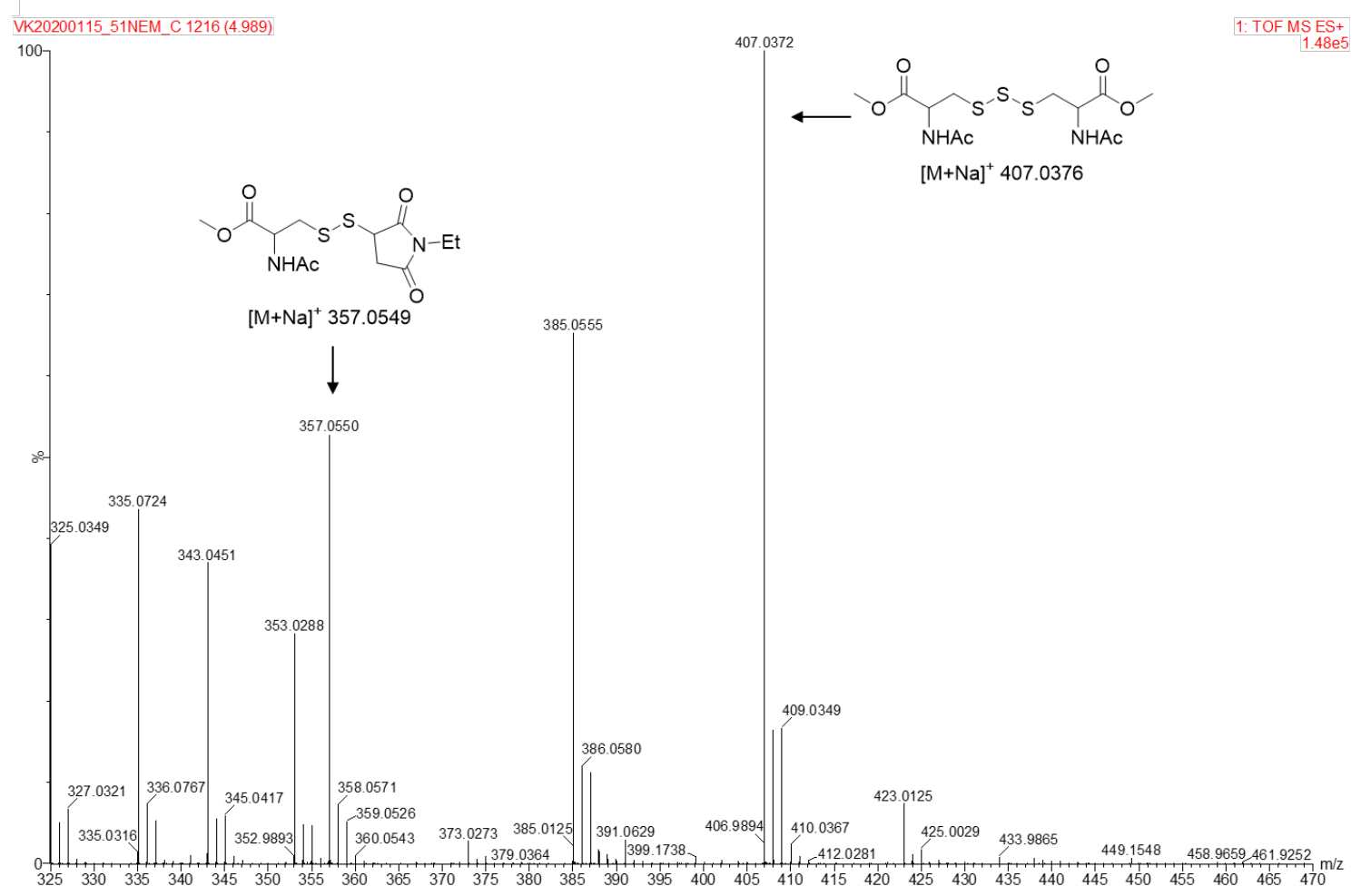

Figure S8. HRMS of the R ${ }^{1}$ SS-NEM coeluted with dialkyltrisulfide 6 at $4.99 \mathrm{~min}$.

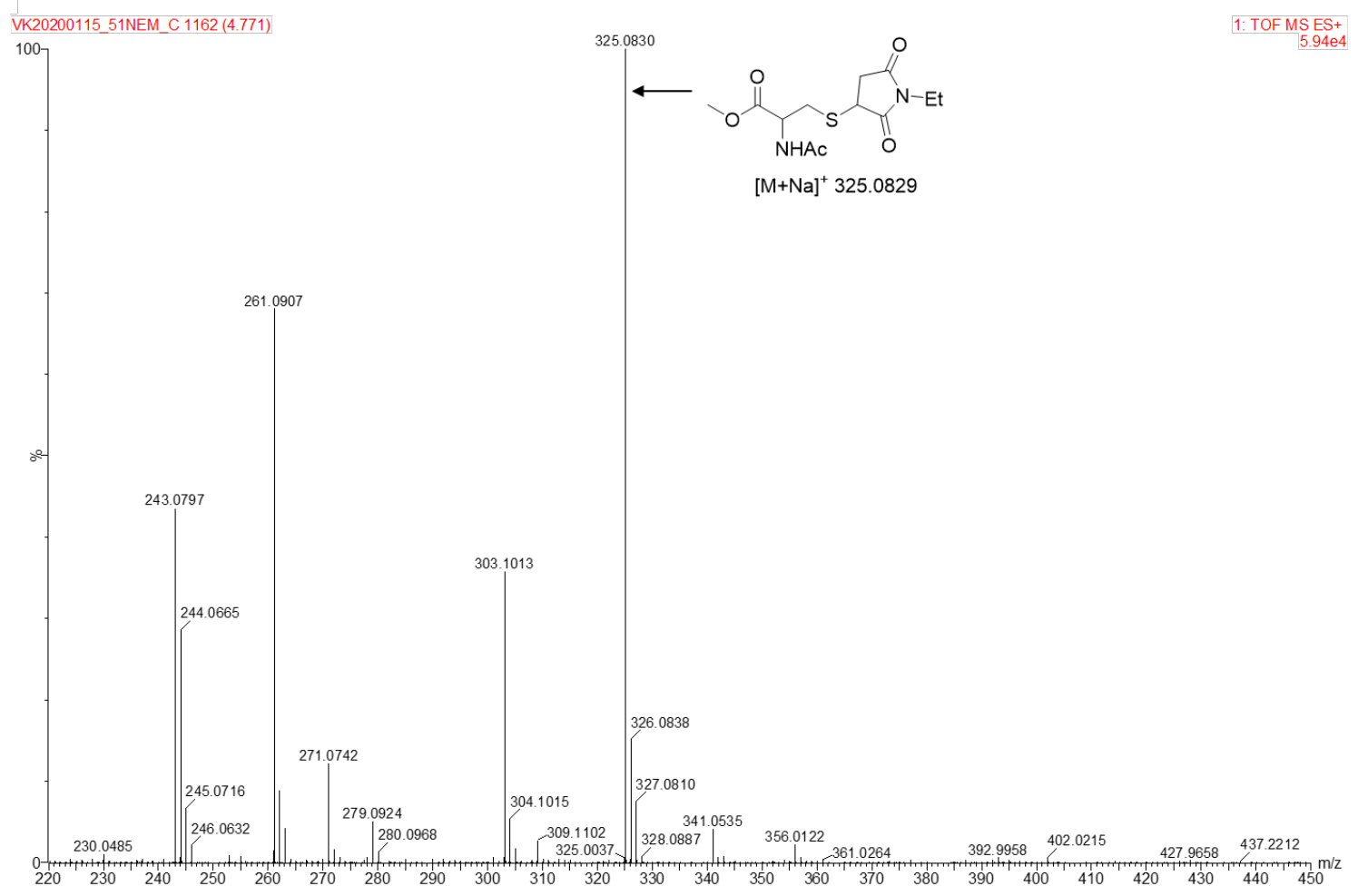

Figure S9. HRMS of the peak eluting at 4.77 min corresponding to ${ }^{1} \mathrm{~S}-\mathrm{NEM}$. 
RSSH generation and quantification of cyclic-ureas 2a-d from 7a-d by UPLC-MS

Precursors 7a-d $(10 \mu \mathrm{M})$ were independently incubated with HPE-IAM $(500 \mu \mathrm{M})$ in $\mathrm{pH} 7.4$ ammonium bicarbonate buffer $(50 \mathrm{mM})$ containing DTPA $(100 \mu \mathrm{M})$ at $37{ }^{\circ} \mathrm{C}$. The reaction mixture $(500 \mu \mathrm{L})$ was analyzed using UPLC-MS. To quantify 2a-d generated from these precursors, we independently generated a calibration curve of each individual cyclic urea with known concentrations.

\section{RSSH generation from $7 \mathrm{a}$ in the presence of HPE-IAM}

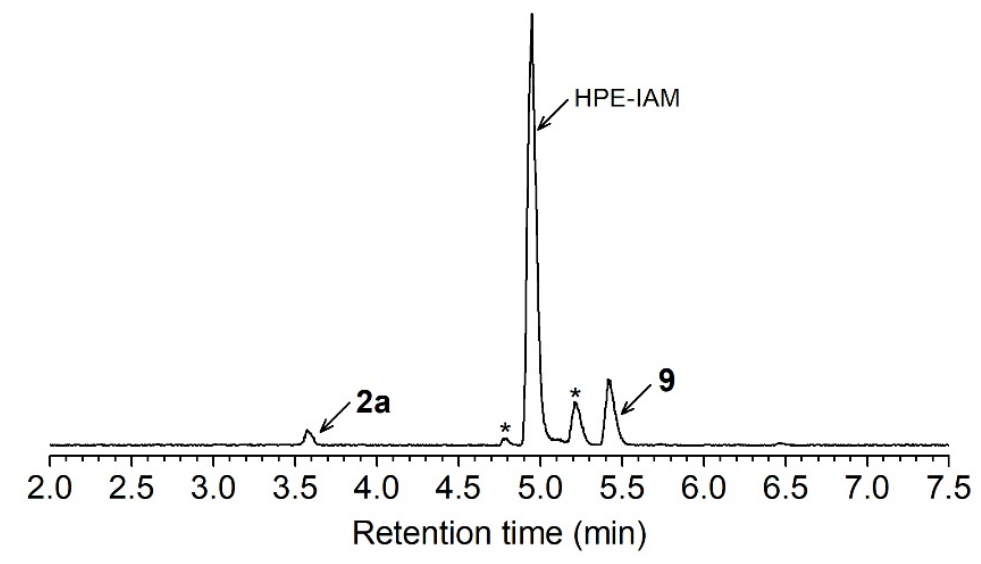

Figure S10. Representative UPLC-MS chromatogram of RSS-HPE-AM 9 generation from $7 \mathbf{a}(10 \mu \mathrm{M})$ incubated with HPE-IAM $(500 \mu \mathrm{M})$ in $\mathrm{pH} 7.4$ ammonium bicarbonate buffer at $37^{\circ} \mathrm{C}$ for $15 \mathrm{~min}$. Under these conditions, $8.7 \pm 0.4 \mu \mathrm{M}$ of byproduct 1,3-dimethyl-2-imidazolidinone (2a) formation is observed. The asterisk indicates the presence of small amount of impurities in the commercial HPE-IAM sample.

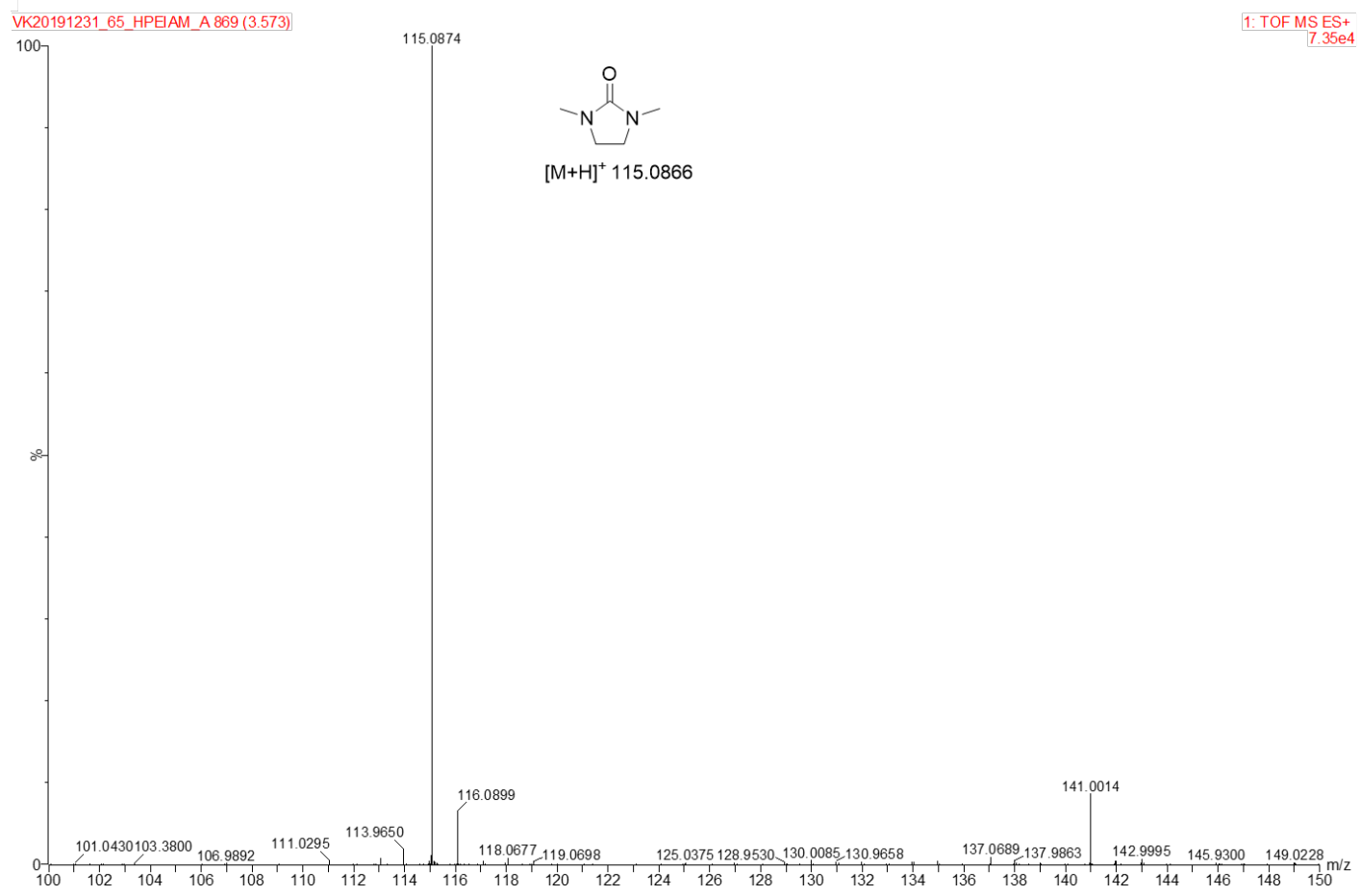

Figure S11. HRMS of the peak eluting at 3.57 min corresponding to byproduct $\mathbf{2 a}$. 


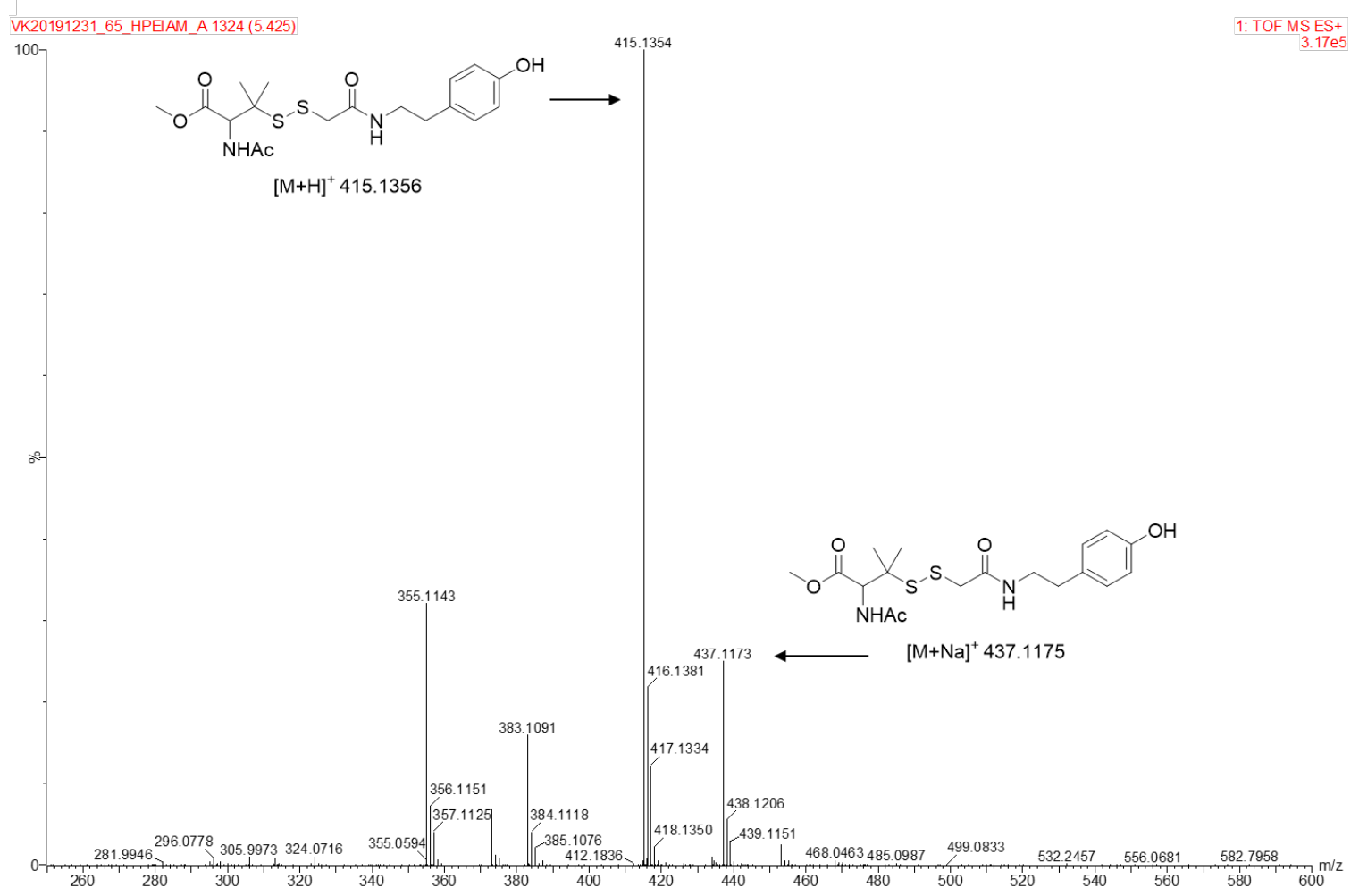

Figure S12. HRMS of the peak eluting at 5.43 min corresponding to RSS-HPE-AM adduct 9.

\section{RSSH generation from $7 \mathrm{~b}$ in the presence of HPE-IAM}

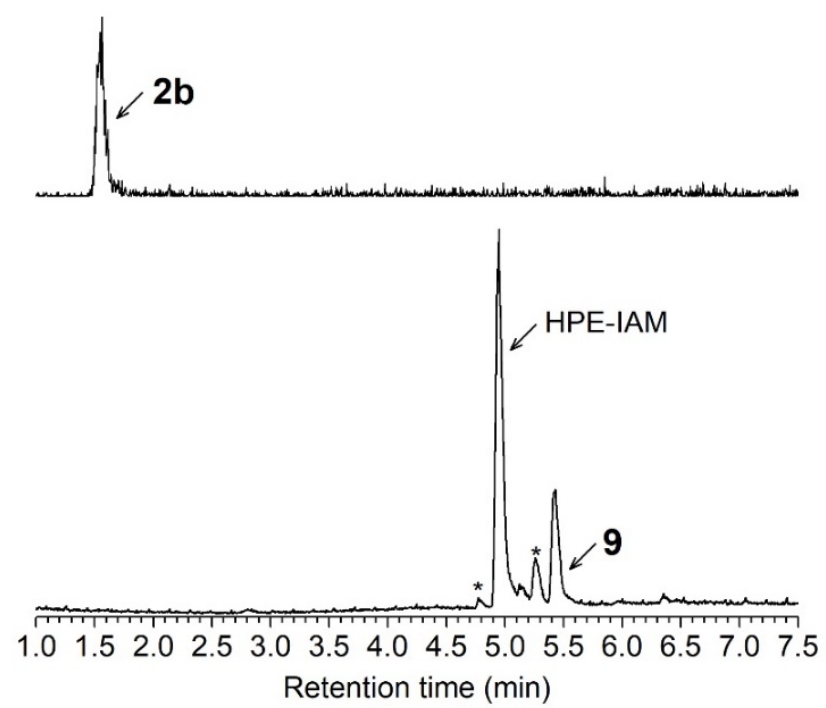

Figure S13. Representative UPLC-MS chromatograms of RSS-HPE-AM 9 generation from $7 \mathbf{b}(10 \mu \mathrm{M})$ incubated with HPE-IAM $(500 \mu \mathrm{M})$ in $\mathrm{pH} 7.4$ ammonium bicarbonate buffer at $37^{\circ} \mathrm{C}$ for $2 \mathrm{~h}$. Under these conditions, $9.5 \pm 0.08 \mu \mathrm{M}$ of byproduct 1-methylimidazolidin-2-one (2b) formation is observed. The asterisk indicates the presence of small amount of impurities in the commercial HPE-IAM sample. Due to low ionization efficiency of $\mathbf{2 b}$ under ESI-positive mode, its extracted mass chromatogram with $\mathrm{m} / \mathrm{z}$ 101.0709 is shown (top trace). 


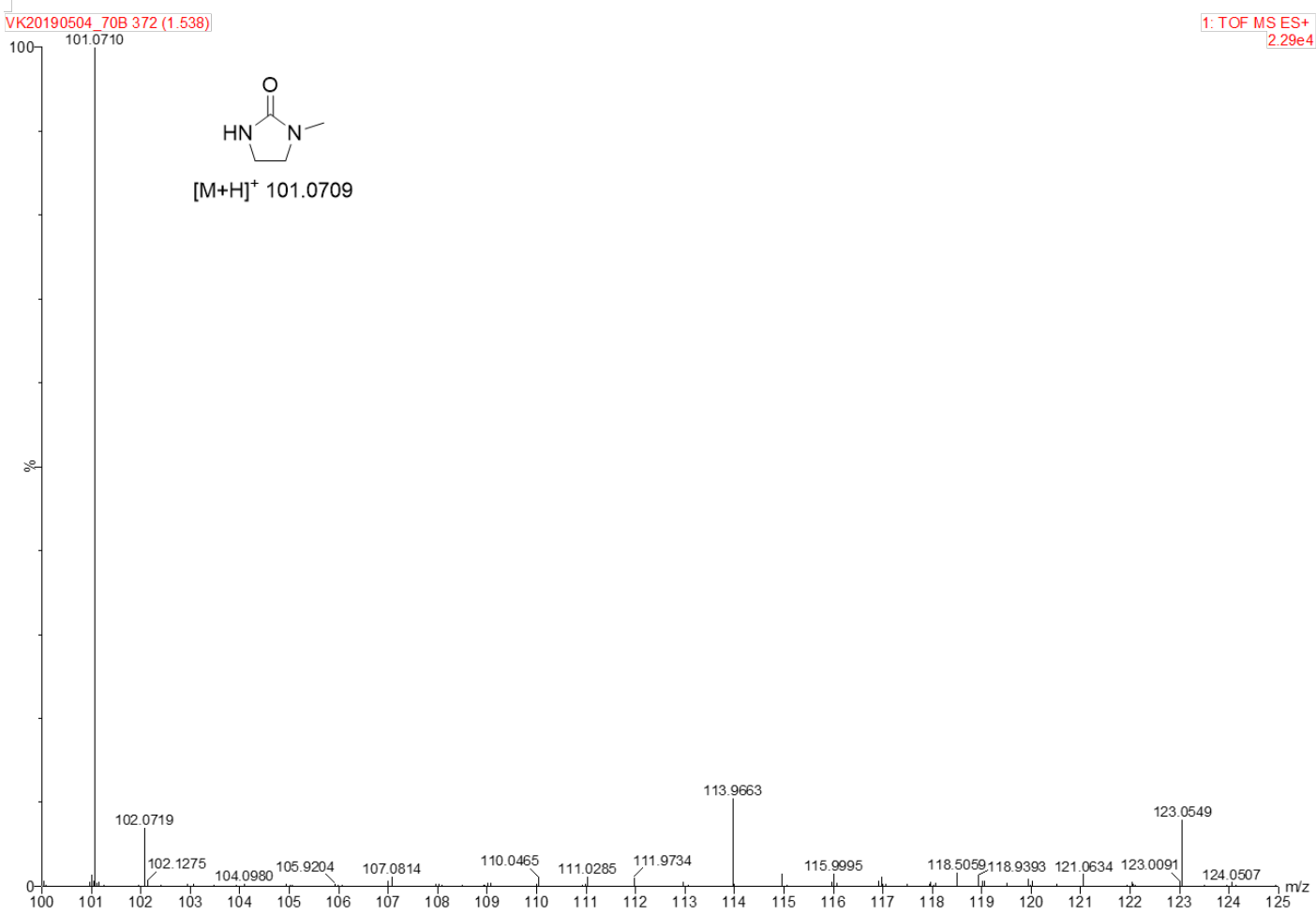

Figure S14. HRMS of the peak eluting at 1.54 min corresponding to byproduct $\mathbf{2 b}$.

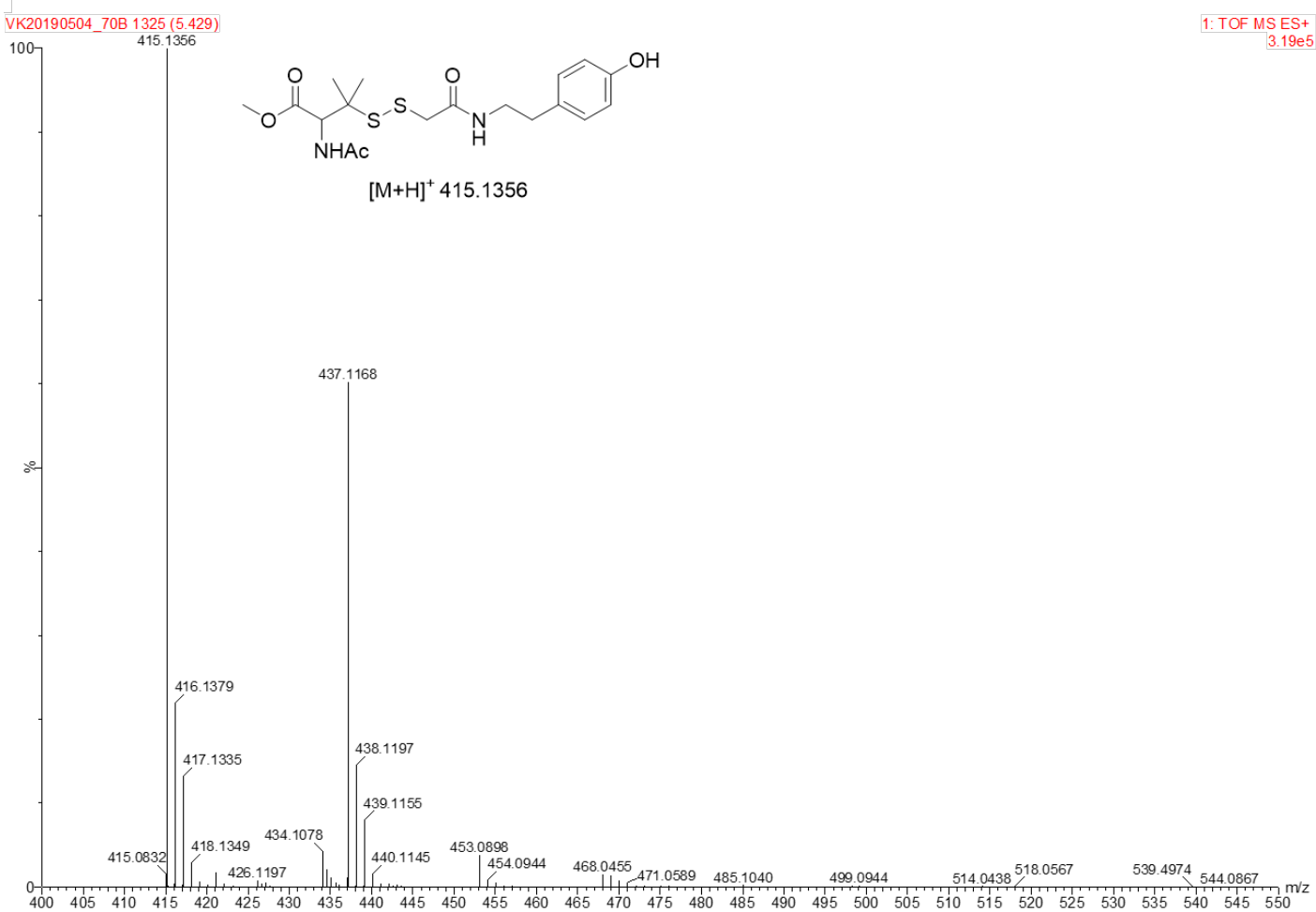

Figure S15. HRMS of the peak eluting at 5.43 min corresponding to RSS-HPE-AM adduct 9. 


\section{RSSH generation from $7 \mathrm{c}$ in the presence of HPE-IAM}

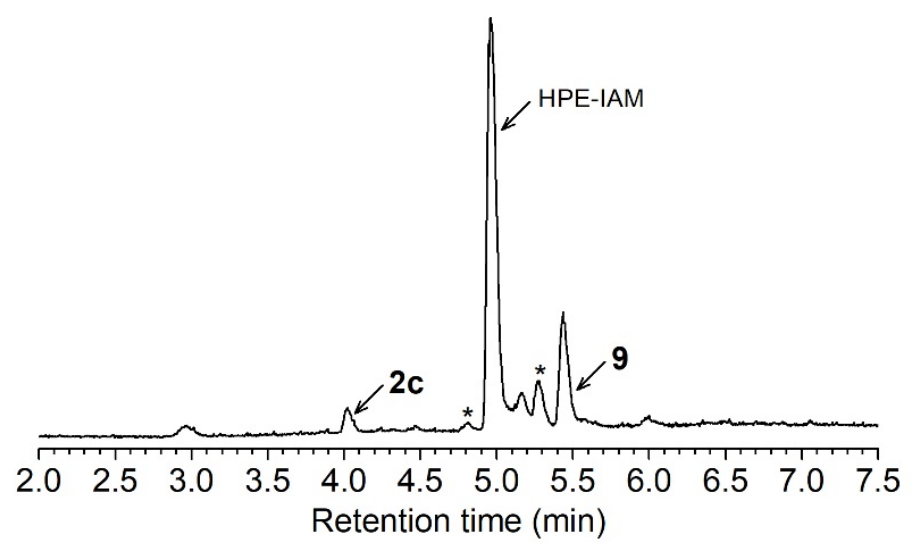

Figure S16. Representative UPLC-MS chromatogram of RSS-HPE-AM 9 generation from $7 \mathbf{c}(10 \mu \mathrm{M})$ incubated with HPE-IAM $(500 \mu \mathrm{M})$ in ammonium bicarbonate $\mathrm{pH} 7.4$ buffer at $37^{\circ} \mathrm{C}$ for $7 \mathrm{~h}$. Under these conditions, $8.8 \pm 0.2 \mu \mathrm{M}$ of 1,3-dimethyltetrahydropyrimidin-2(1H)-one (2c) formation is observed. The asterisk indicates the presence of small amount of impurities in the commercial HPE-IAM sample. A peak at 5.2 min represents a minor amount of thiol-HPE-AM adduct formation, suggesting that excess of HPEIAM reacts with 9 to produce RS-HPE-AM. A peak at $2.95 \mathrm{~min}$ corresponding to the $\beta$-(4hydroxyphenyl)ethyl-2-aminoacetamide, presumably formed by the ammonolysis of HPE-IAM.

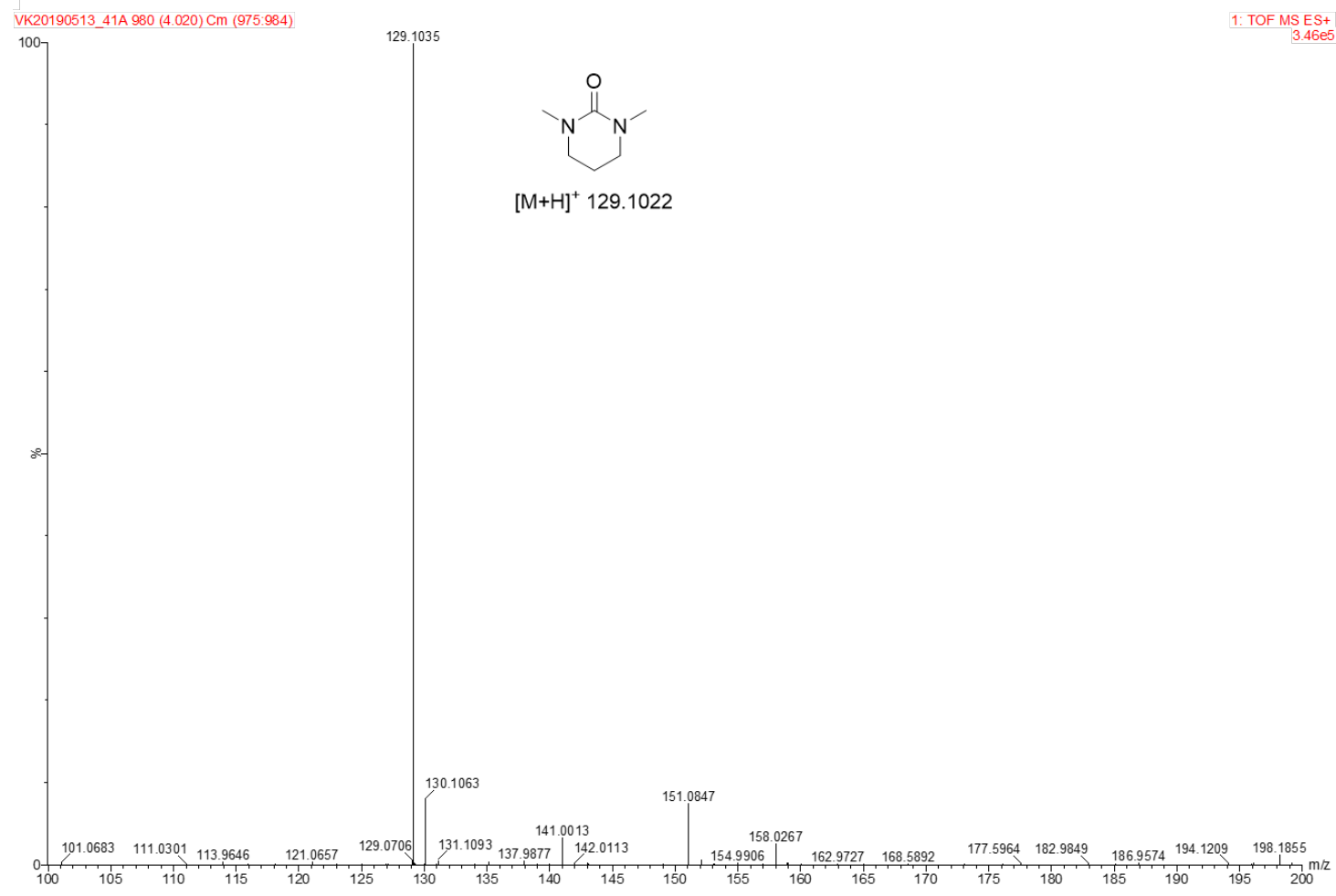

Figure S17. HRMS of the peak eluting at 4.05 min corresponding to byproduct $\mathbf{2 c}$. 


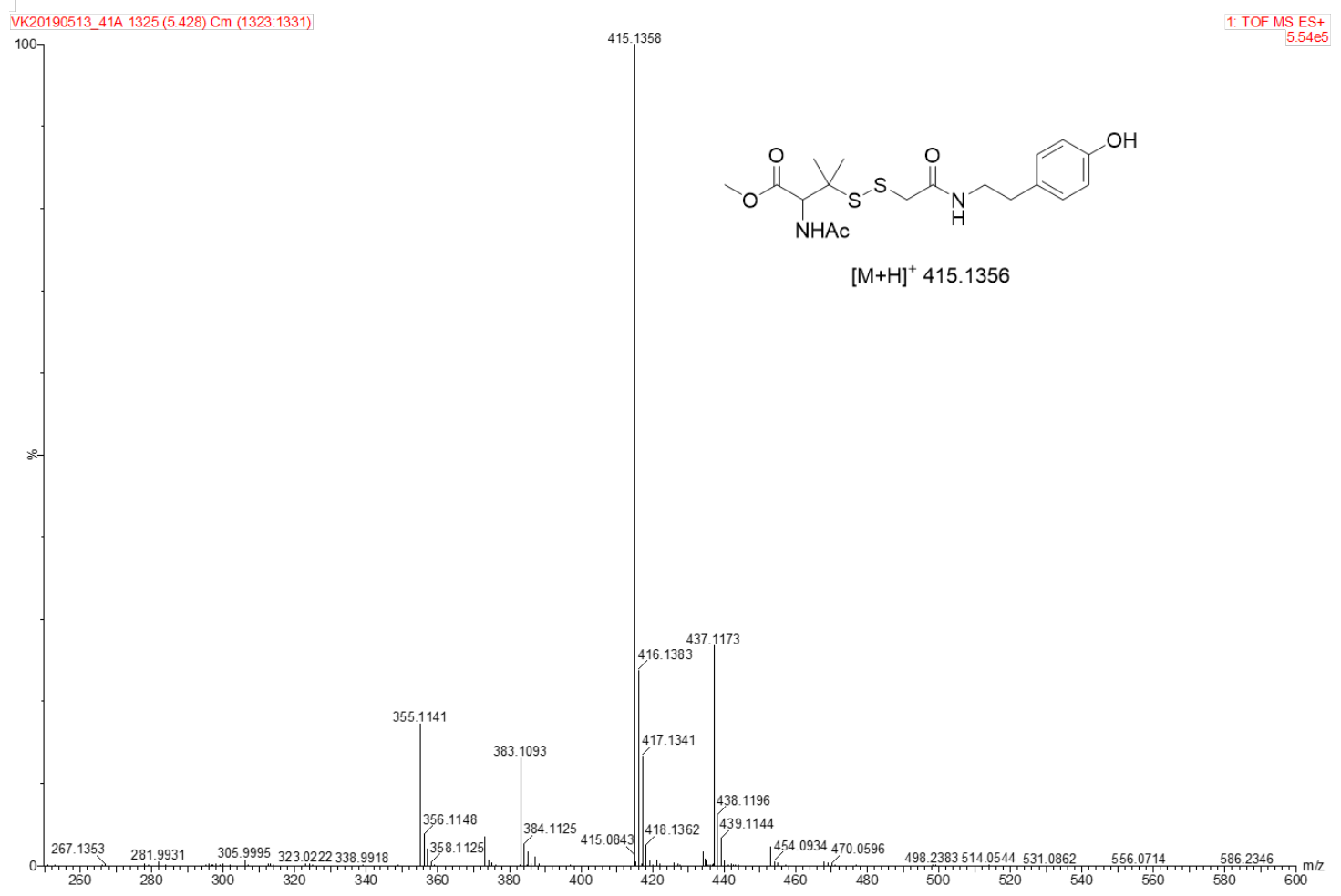

Figure S18. HRMS of the peak eluting at 5.43 min corresponding to RSS-HPE-AM adduct 9.

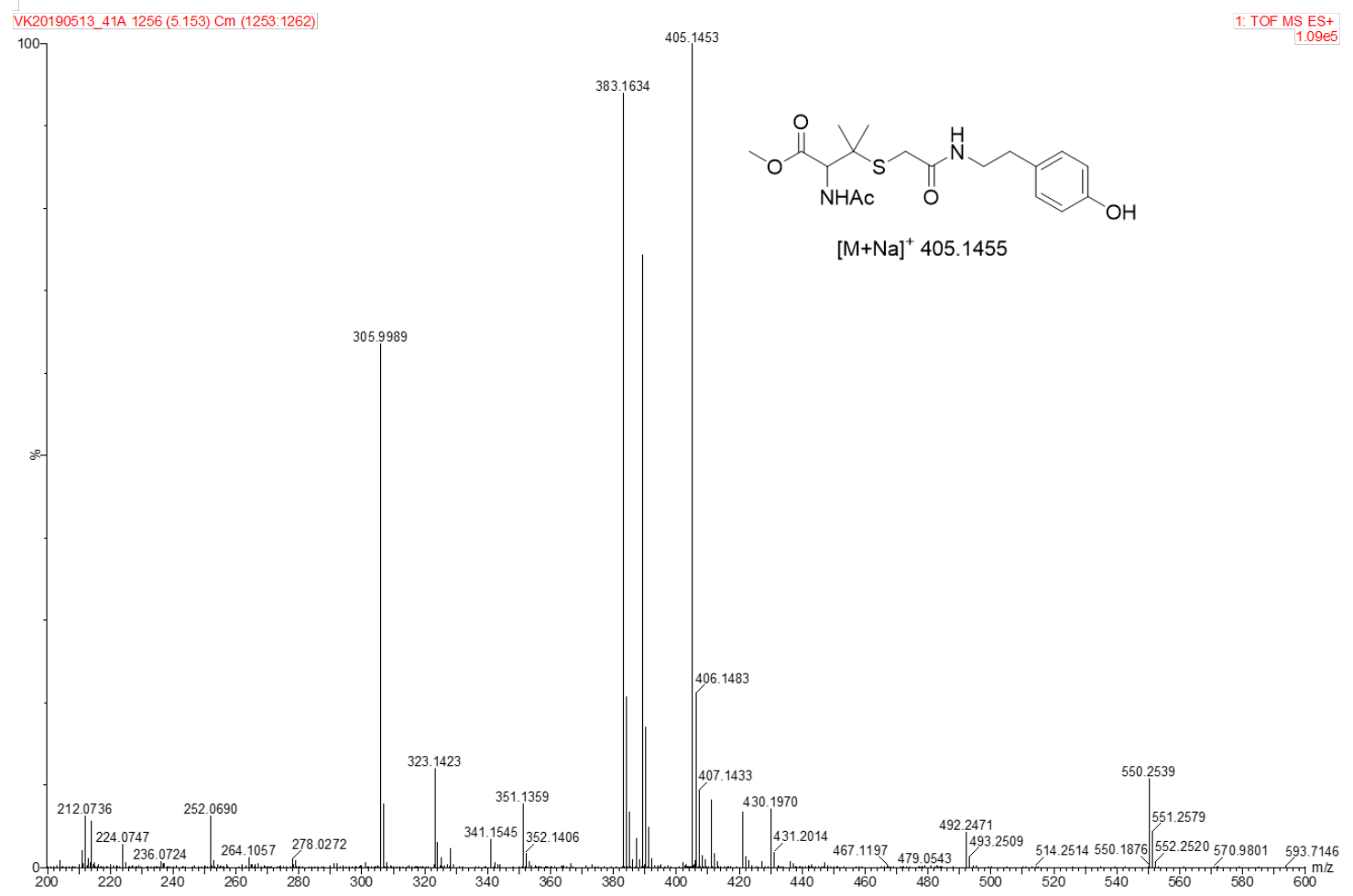

Figure S19. HRMS of the peak eluting at 5.15 min corresponding to RS-HPE-AM. 


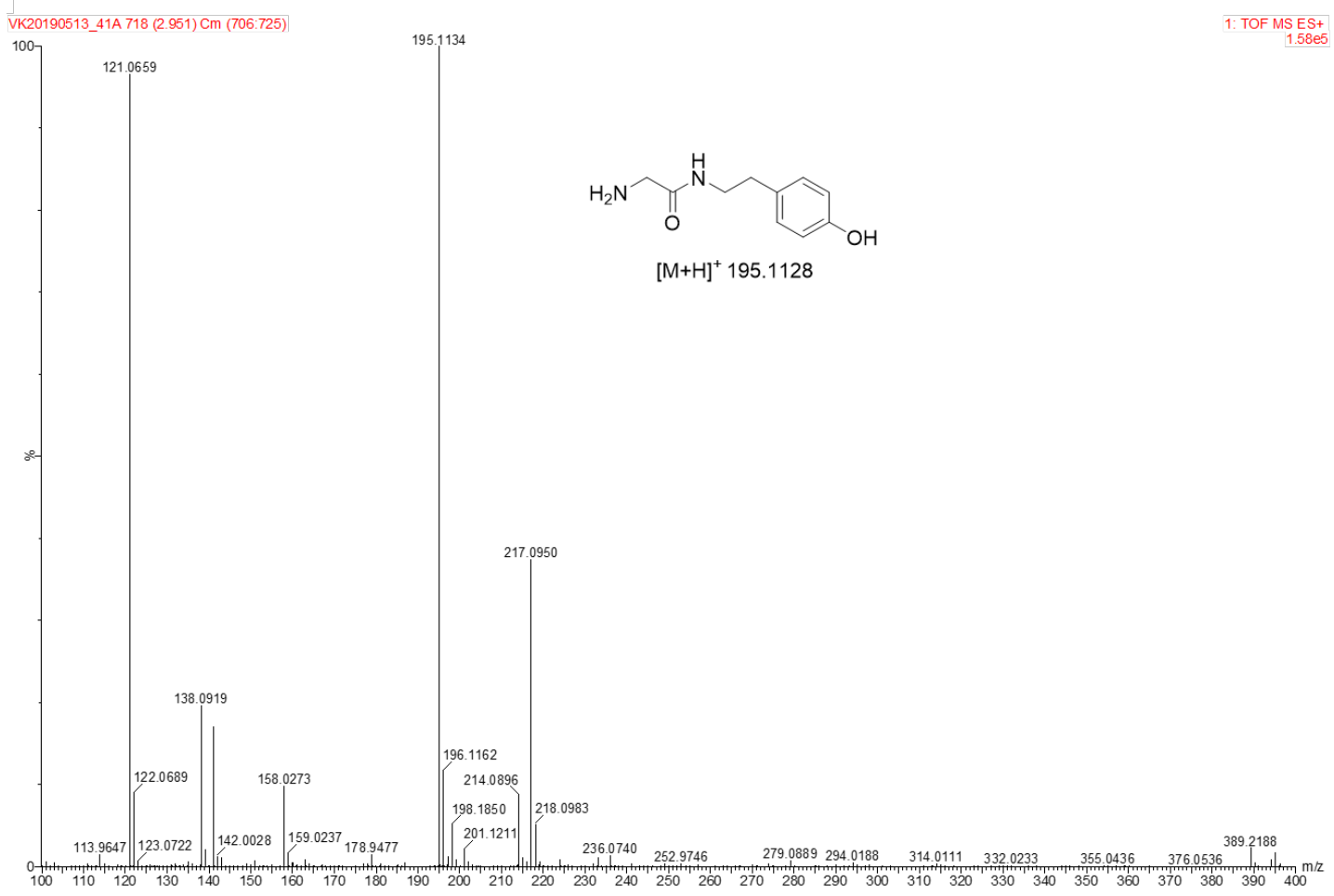

Figure S20. HRMS of the peak eluting at 2.96 min corresponding to $\beta$-(4-hydroxyphenyl)ethyl-2aminoacetamide.

\section{RSSH generation from $7 \mathrm{~d}$ in the presence of HPE-IAM}

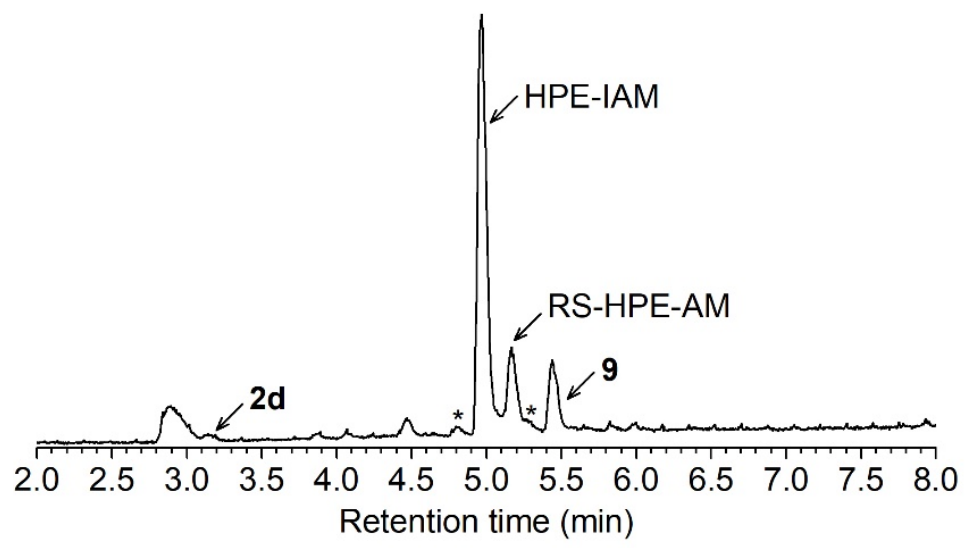

Figure S21. Representative UPLC-MS chromatogram of RSS-HPE-AM 9 generation from 7d $(10 \mu \mathrm{M})$ incubated with HPE-IAM $(500 \mu \mathrm{M})$ in $\mathrm{pH} 7.4$ ammonium bicarbonate buffer at $37{ }^{\circ} \mathrm{C}$ for $42 \mathrm{~h}$. Under these conditions, $8.0 \pm 0.4 \mu \mathrm{M}$ of 1-methyltetrahydropyrimidin-2 $(1 H)$-one (2d) formation is observed. The asterisk indicates the presence of small amount of impurities in the commercial HPE-IAM sample. A peak at $5.2 \mathrm{~min}$ represents thiol-HPE-AM adduct formation after $42 \mathrm{~h}$, suggesting that excess of HPE-IAM reacts with 9 to produce RS-HPE-AM. A peak at 2.95 min corresponding to the $\beta$-(4-hydroxyphenyl)ethyl-2aminoacetamide suggest that the HPE-IAM reacts with ammonia generated from the volatile ammonium bicarbonate buffer. 


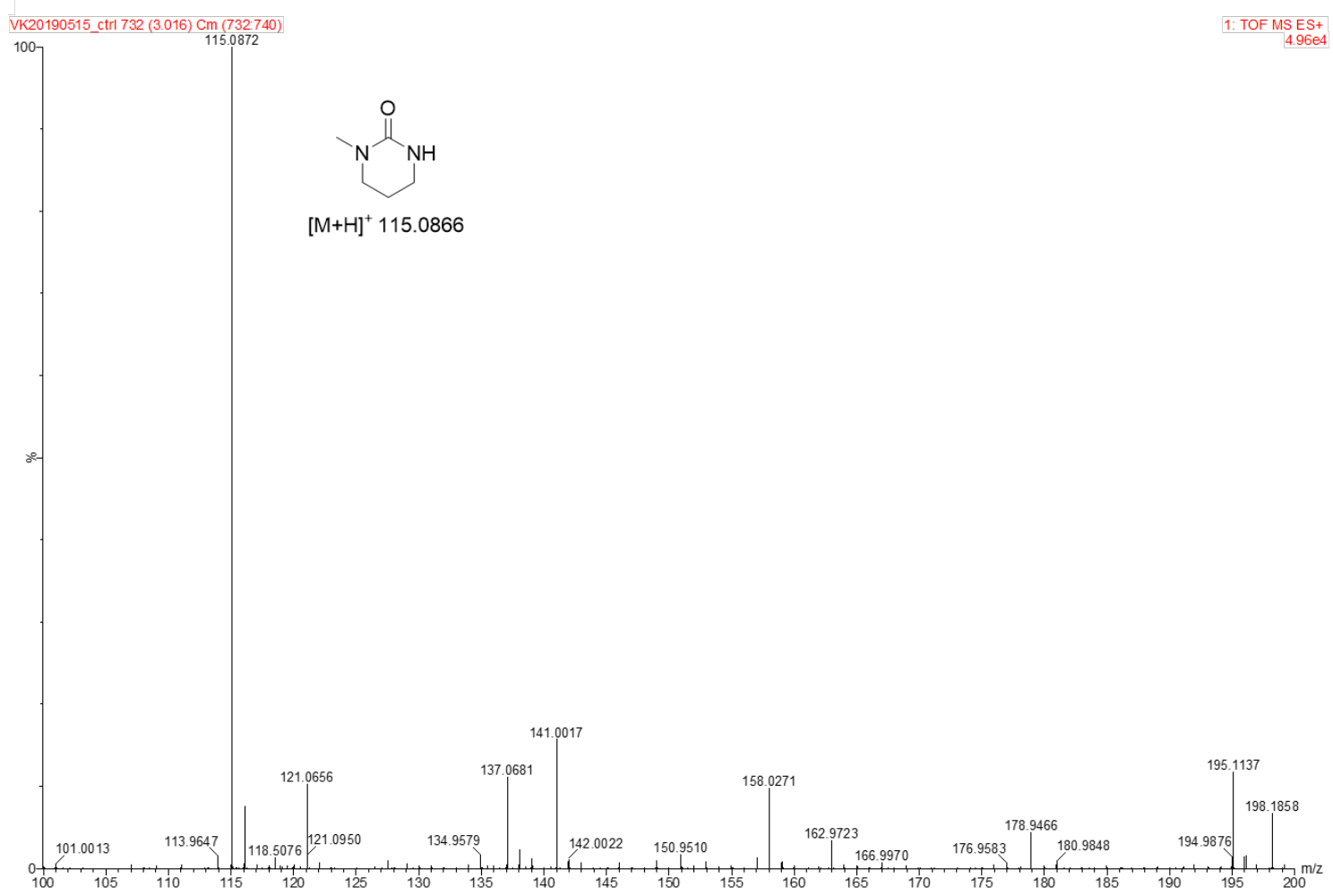

Figure S22. HRMS of the peak eluting at $3.01 \mathrm{~min}$ corresponding to byproduct $\mathbf{2 d}$.

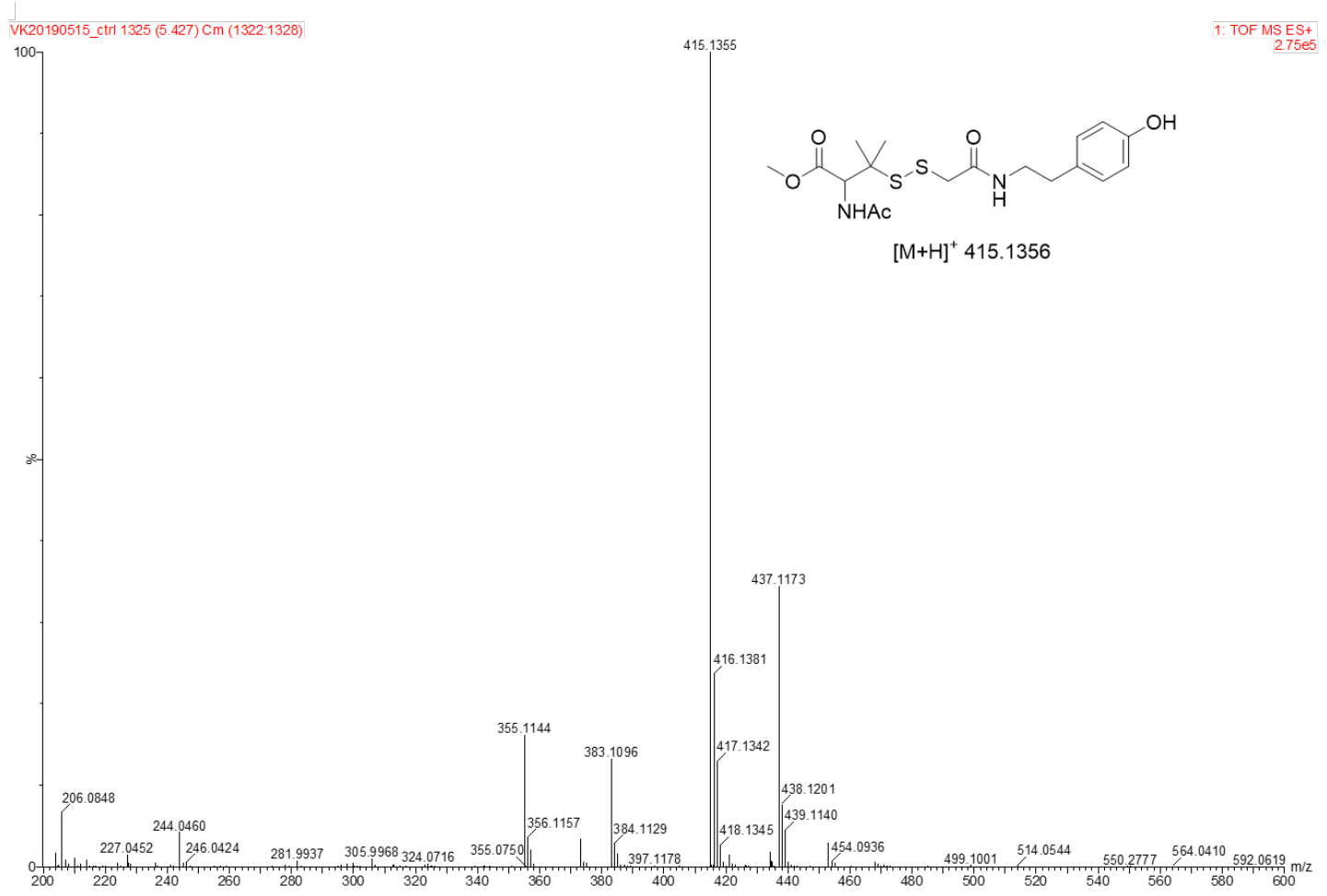

Figure S23. HRMS of the peak eluting at 5.43 min corresponding to RSS-HPE-AM adduct 9. 


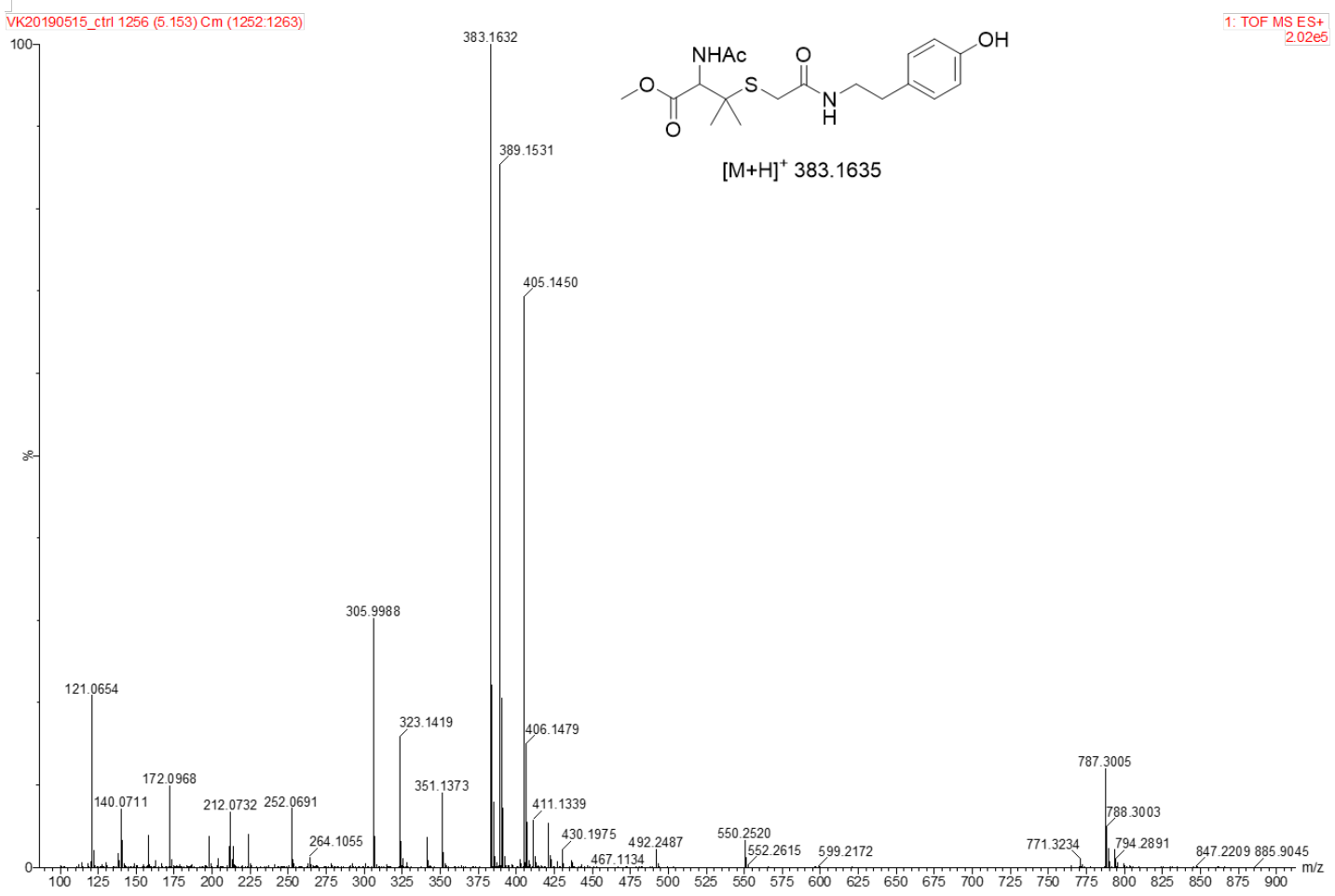

Figure S24. HRMS of the peak eluting at 5.15 min corresponding to RS-HPE-AM.

\section{Reactivity of control compound 8}

\section{Stability of control compound 8 at $\mathrm{pH} 7.4$}

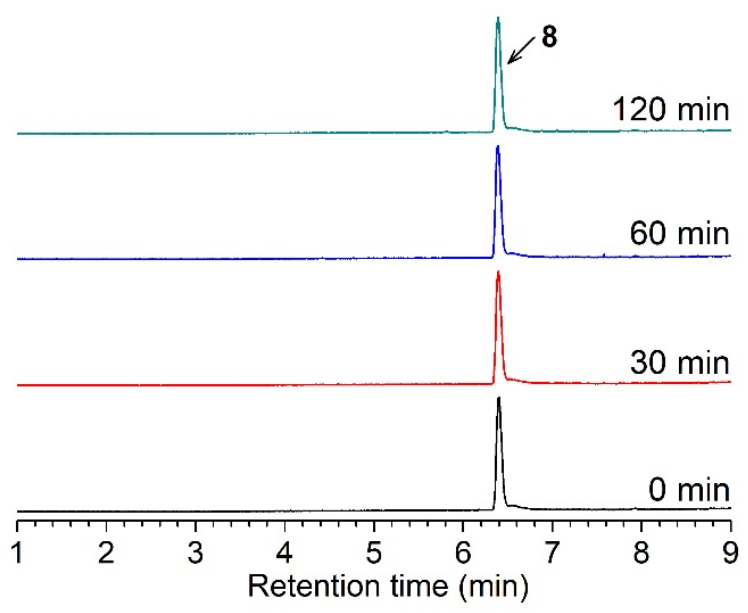

Figure S25. UPLC-MS chromatogram of $8(100 \mu \mathrm{M})$ incubated in $\mathrm{pH} 7.4$ ammonium bicarbonate buffer at $37^{\circ} \mathrm{C}$. Aliquots taken at various times were quenched with $1 \%$ formic acid and analyzed by UPLC-MS. These data indicate that control compound $\mathbf{8}$ is stable under these conditions and does not produce RSSH. 


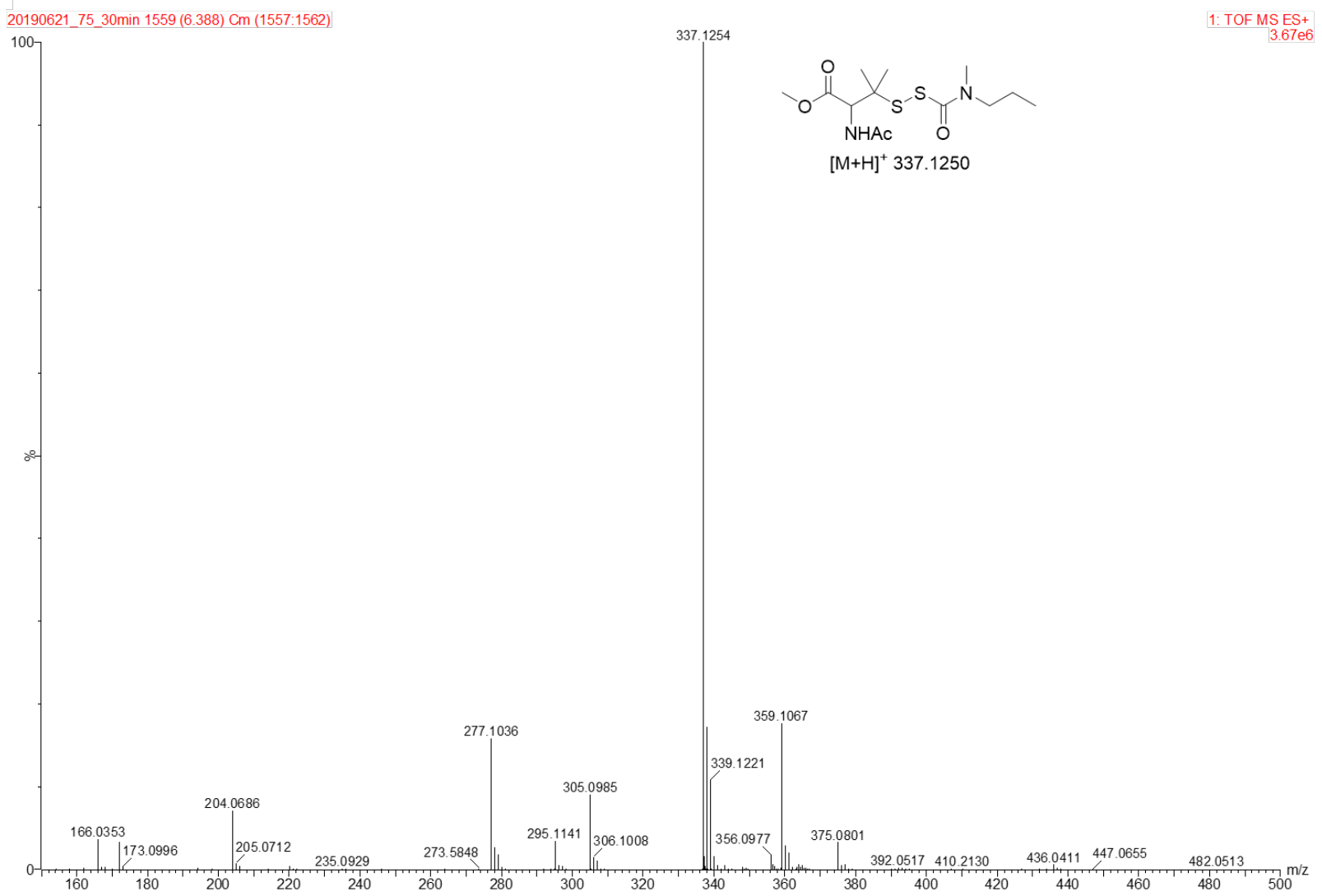

Figure S26. HRMS of the peak eluting at 6.39 min corresponding to control compound 8 . 


\section{Lack of reaction of control compound 8 with $n$-BuNH}

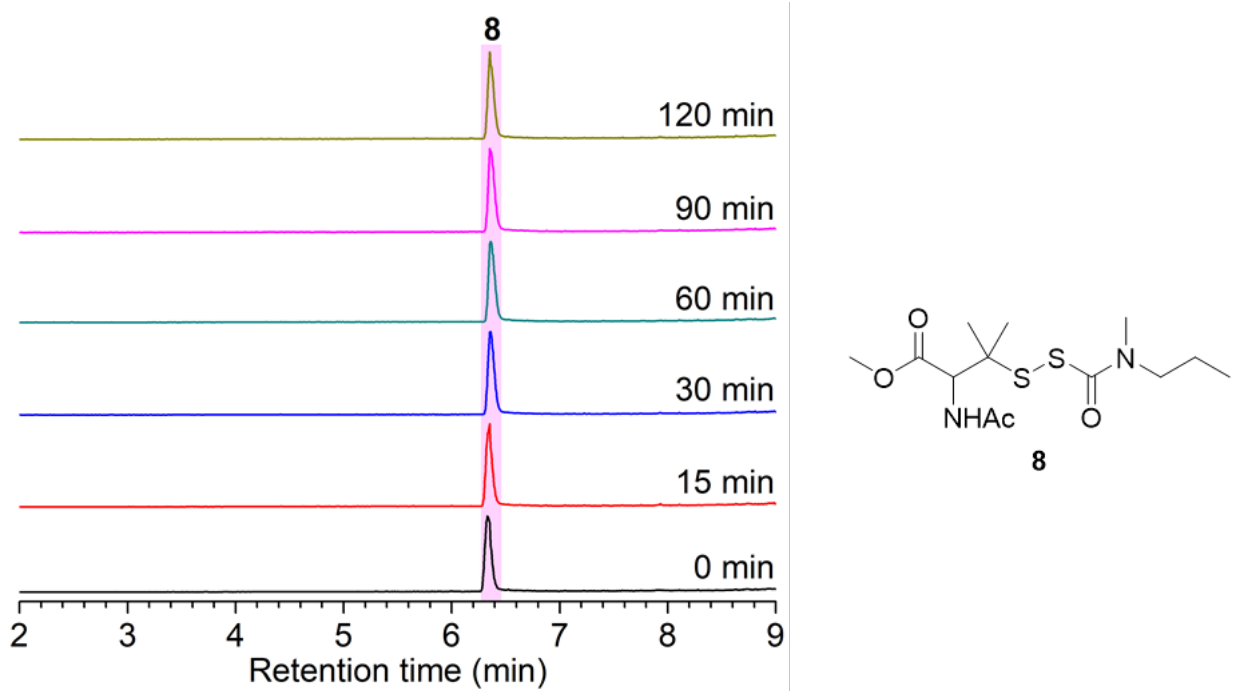

Figure S27. UPLC-MS chromatograms of control compound $8(100 \mu \mathrm{M})$ reaction with $n$-BuNH $\mathrm{Bu}_{2}(500$ $\mu \mathrm{M})$ in $\mathrm{pH} 7.4$ ammonium bicarbonate: acetonitrile (9:1) with the metal chelator DTPA $(100 \mu \mathrm{M})$ at $37^{\circ} \mathrm{C}$. Aliquots $(200 \mu \mathrm{L})$ were taken at specified time points, quenched with $1 \%$ formic acid $(200 \mu \mathrm{L})$ and analyzed using UPLC-MS. The lack of reaction of $\mathbf{8}$ with $n-\mathrm{BuNH}_{2}$ indicates no RSSH release via this intermolecular reaction.

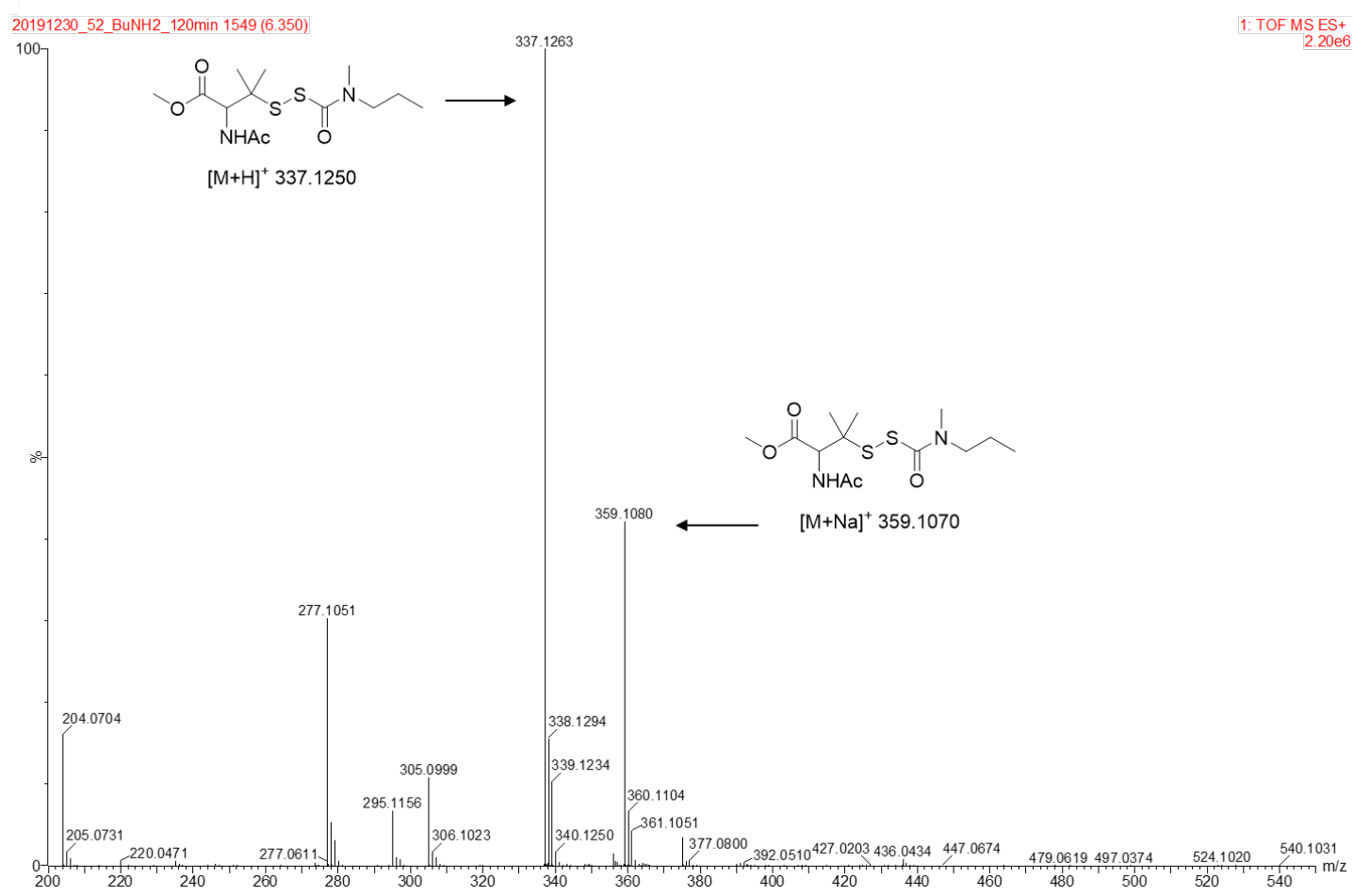

Figure S28. HRMS of the peak eluting at 6.33 min corresponding to control compound $\mathbf{8}$. 


\section{Analysis of control compound 8 reaction with $\mathrm{N}$-acetyl-cysteine}

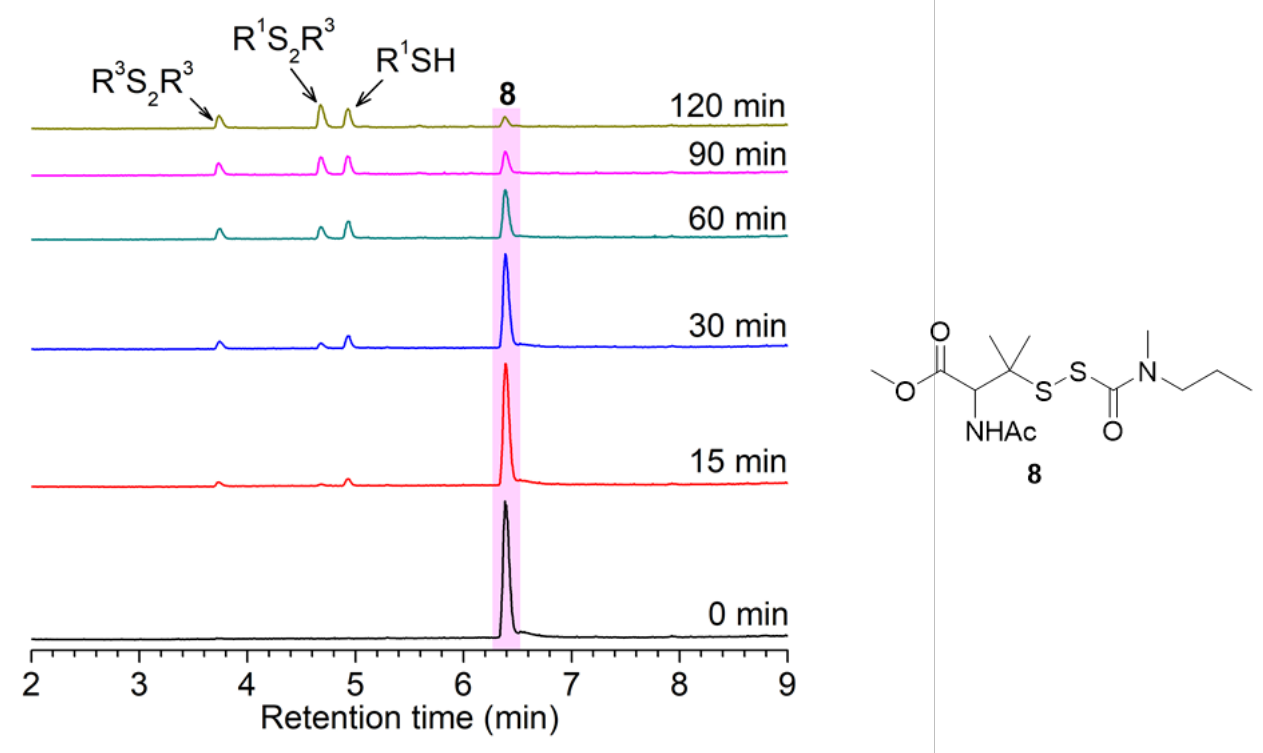

Figure S29. UPLC-MS chromatograms of control compound $8(100 \mu \mathrm{M})$ reaction with NAC $(500 \mu \mathrm{M})$ in $\mathrm{pH} 7.4$ ammonium bicarbonate $(50 \mathrm{mM})$ with the metal chelator DTPA $(100 \mu \mathrm{M})$ at $37^{\circ} \mathrm{C}$. Aliquots $(200$ $\mu \mathrm{L})$ were taken at specified time points, quenched with $1 \%$ formic acid $(200 \mu \mathrm{L})$ and analyzed using UPLCMS.

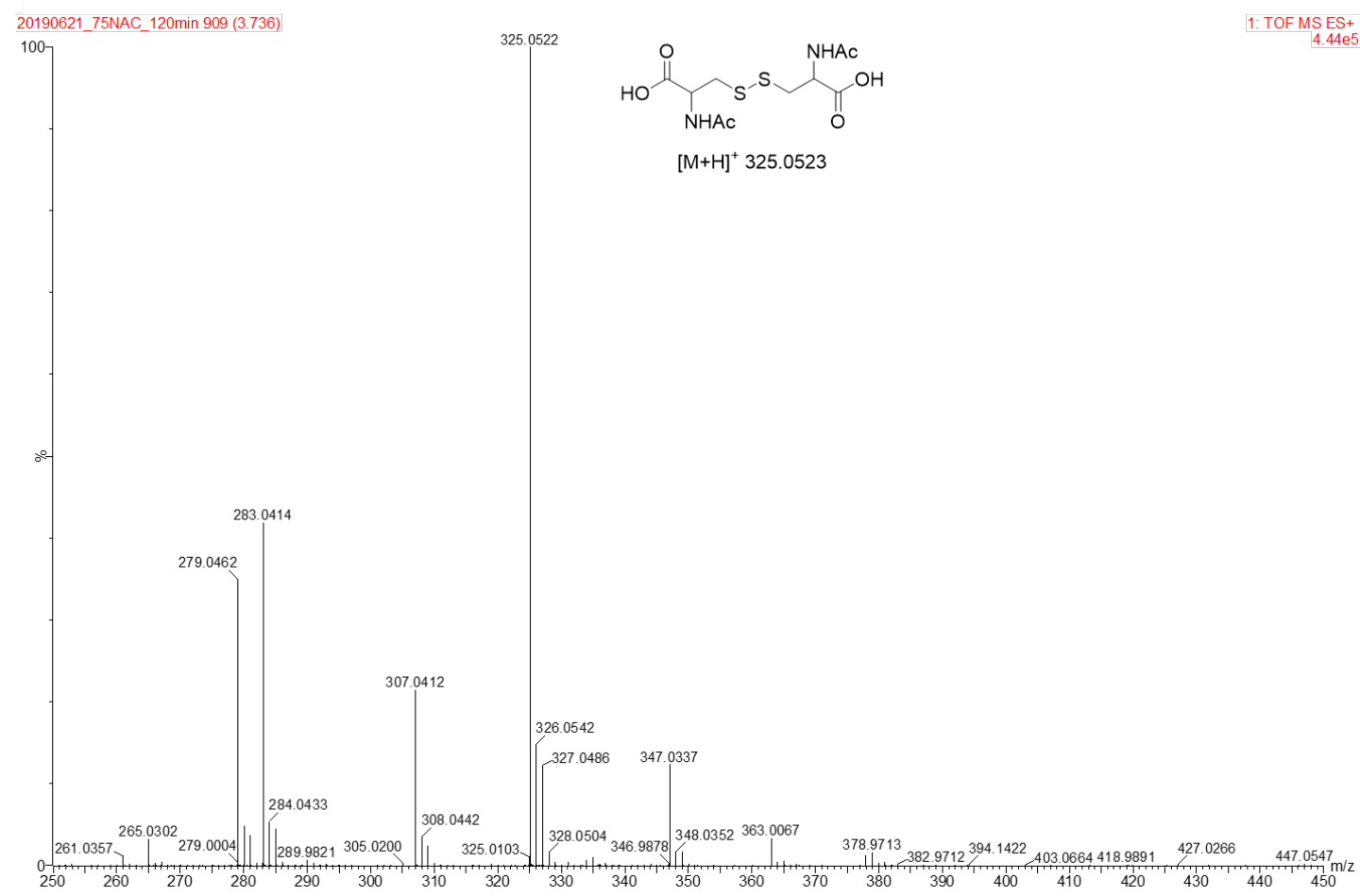

Figure S30. HRMS of the peak eluting at 3.74 min corresponding to $N$-acetyl cystine $\left(\mathrm{R}^{3} \mathrm{SSR}^{3}\right)$. 


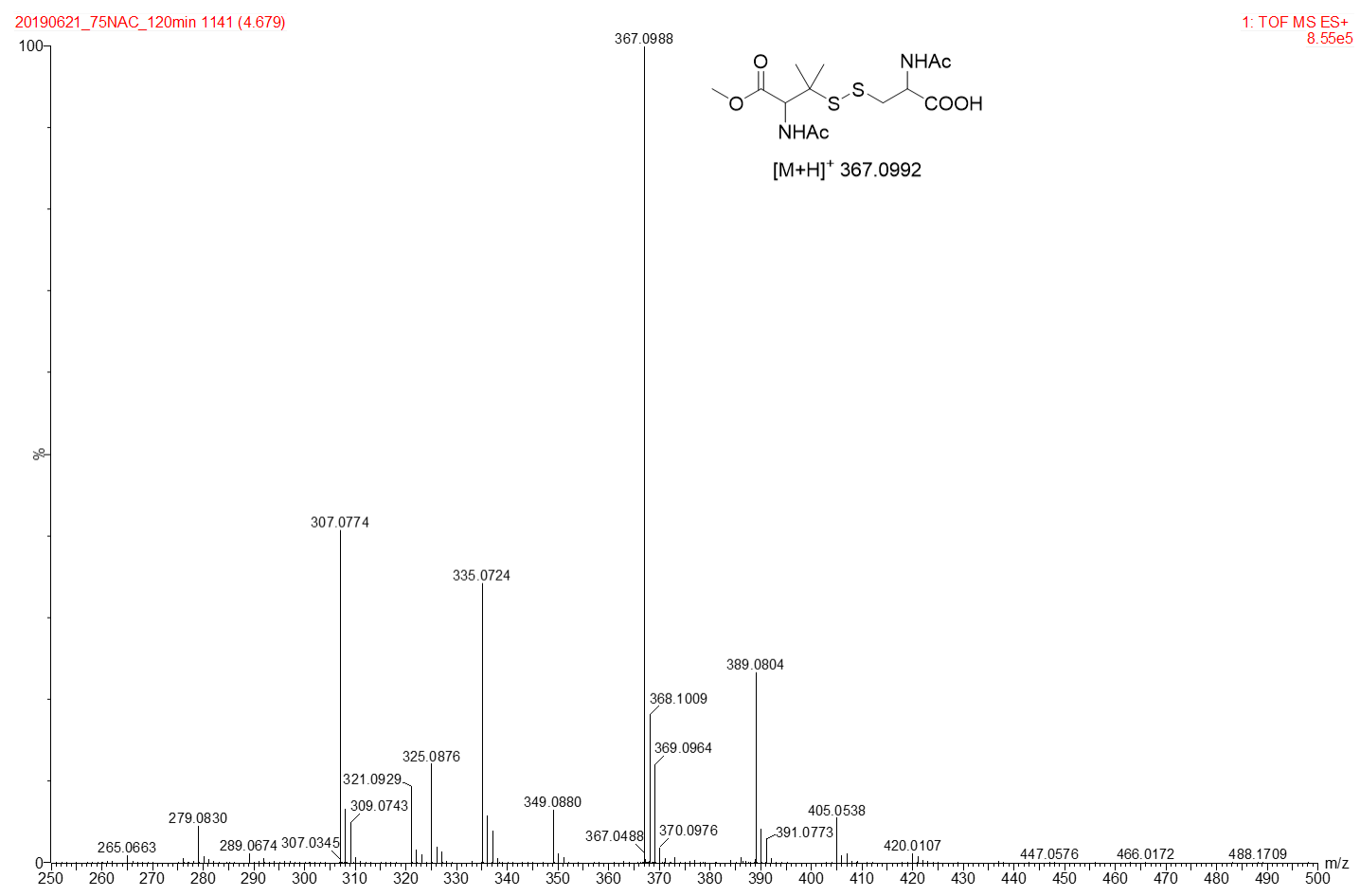

Figure S31. HRMS of the peak eluting at 4.68 min corresponding to mixed disulfide $\left(\mathrm{R}^{1} \mathrm{SSR}^{3}\right)$.

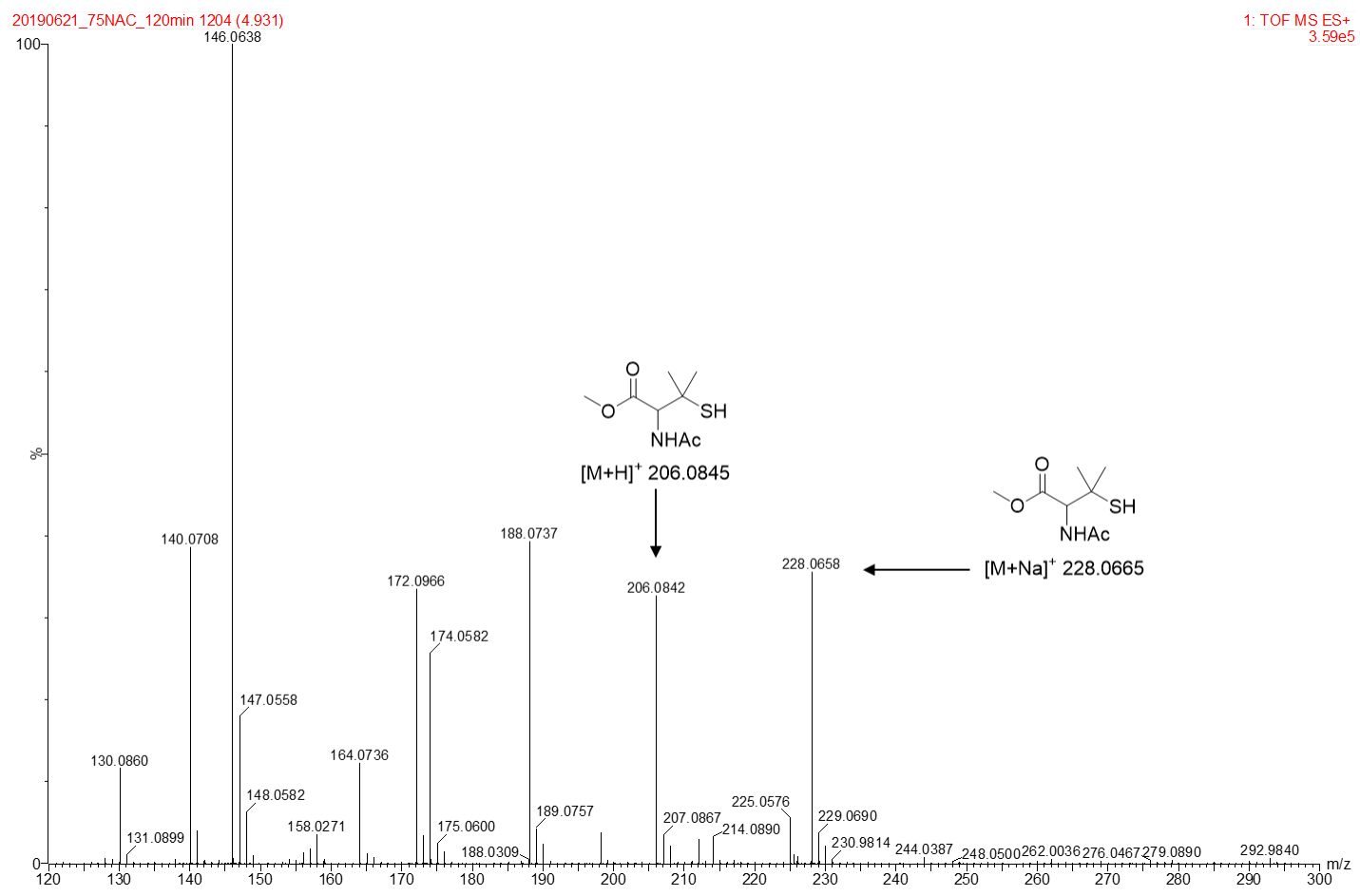

Figure S32. HRMS of the peak eluting at 4.93 min corresponding to $N$-acetyl-penicillamine methyl ester $\left(\mathrm{R}^{1} \mathrm{SH}\right)$. 


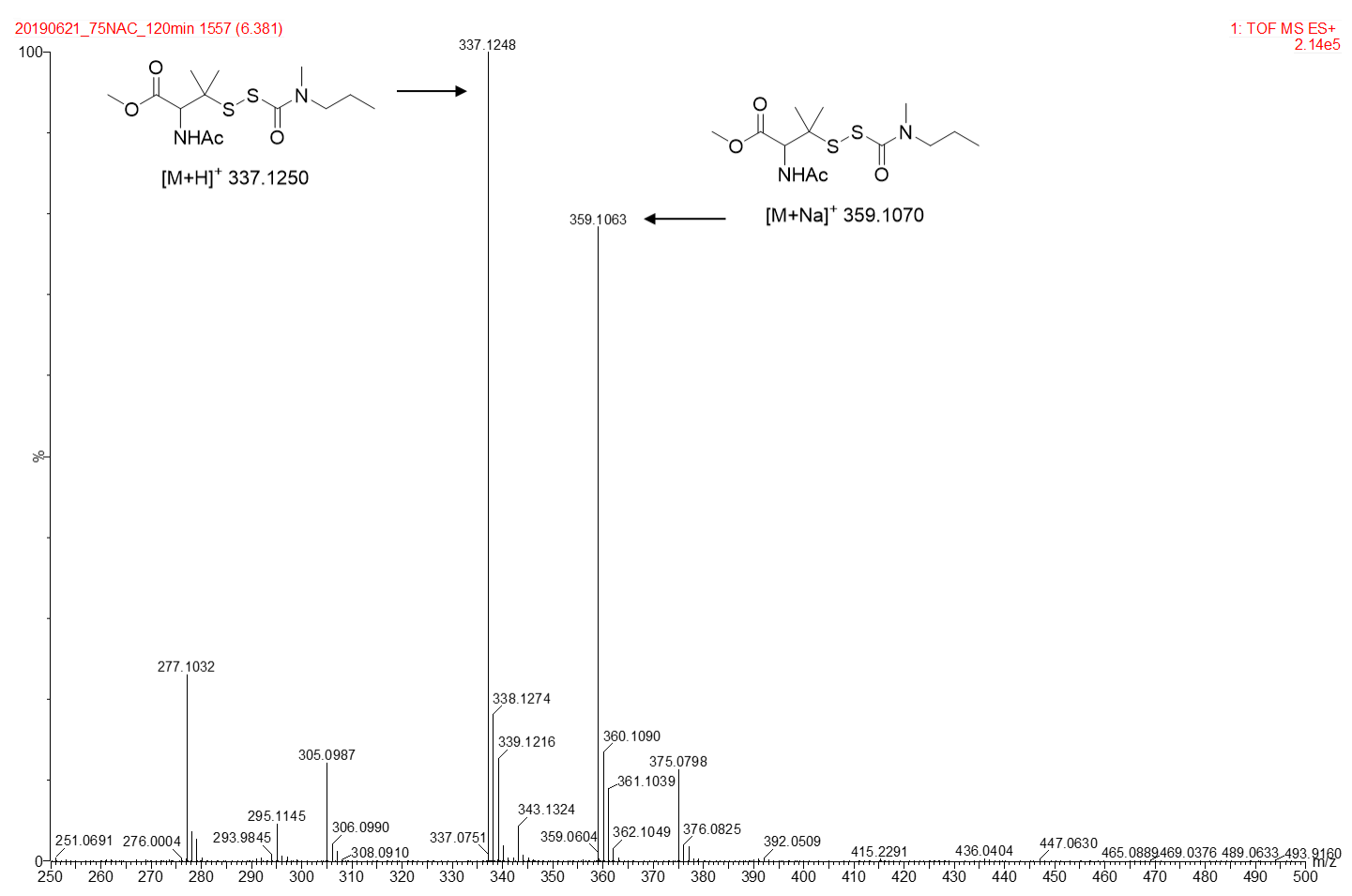

Figure S33. HRMS of the peak eluting at 6.38 min corresponding to control compound 8 .

\section{Kinetics of RSSH release from precursors 7a-d monitored by HPLC}

Precursors 7a-d were dissolved in DMSO to afford $10 \mathrm{mM}$ stock solutions. HPE-IAM was dissolved in DMSO to obtain a $100 \mathrm{mM}$ stock solution. To a $20 \mathrm{~mL}$ scintillation vial, HPE-IAM $(150 \mu \mathrm{L}, 100 \mathrm{mM})$ was diluted in $\mathrm{pH} 7.4$ phosphate buffer $(2.82 \mathrm{~mL})$ containing the DTPA $(100$ $\mu \mathrm{M})$. This solution was pre-incubated for $10 \mathrm{~min}$ at $37^{\circ} \mathrm{C}$ and then precursor $7 \mathbf{a}-\mathbf{d}(30 \mu \mathrm{L}, 10$ $\mathrm{mM}$ ) were independently added into the mixture. The resulting solution was incubated at $37^{\circ} \mathrm{C}$. At different time points, an aliquot of $200 \mu \mathrm{L}$ was taken and quenched with $200 \mu \mathrm{L} 1 \%$ formic acid solution. These samples were stored at $0{ }^{\circ} \mathrm{C}$ until HPLC analysis was performed. The sample $(20 \mu \mathrm{L})$ was injected into a high-performance liquid chromatography (HPLC) equipped with Phenomenex C-18 reverse phase column $(250 \mathrm{~mm} \times 4.6 \mathrm{~mm}, 5 \mu \mathrm{m})$. HPLC Method: mobile phase A $\left(\mathrm{H}_{2} \mathrm{O}\right)$ and mobile phase $\mathrm{B}(\mathrm{ACN})$, flow rate: $1 \mathrm{~mL} / \mathrm{min}$, run time: $20 \mathrm{~min}$, the gradient elution method: $10 \%$ to $40 \%$ B from 0 to $12 \mathrm{~min}, 40 \%$ to $80 \%$ B from 12 to $20 \mathrm{~min}$. The elution was monitored by a UV detector at $275 \mathrm{~nm}$. A calibration curve was generated using RSS-HPE-AM 9 to quantify RSSH generation from 7a-d. 


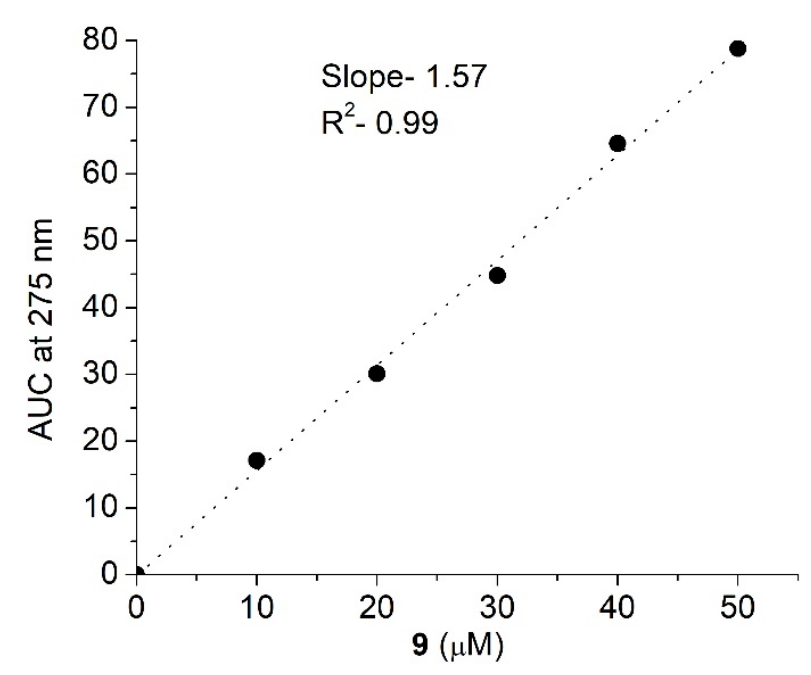

Figure S34. Calibration curve of RSS-HP-AM adduct 9 using HPLC.

(a)

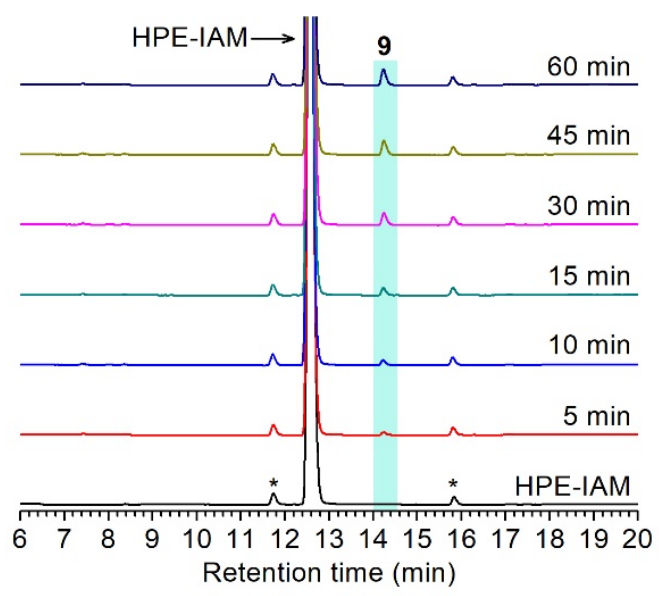

(b)

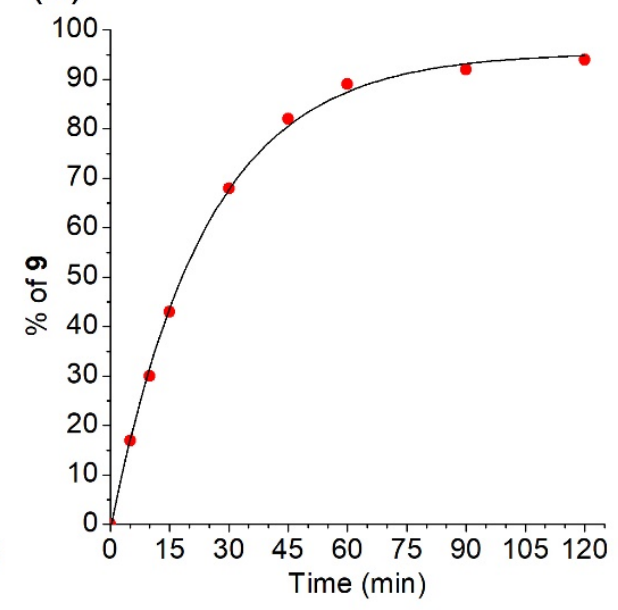

Figure S35. (a) HPLC traces of RSSH generation from $7 \mathbf{b}(100 \mu \mathrm{M})$ in the presence of HPE-IAM $(5 \mathrm{mM})$ incubated in pH 7.4 phosphate buffer $(100 \mathrm{mM})$ with DTPA $(100 \mu \mathrm{M})$ at $37^{\circ} \mathrm{C}$. An aliquot of the reaction mixture was withdrawn at specified time points and quenched with $1 \%$ formic acid. The asterisk indicates the presence of small amount of impurities in the commercial HPE-IAM sample. (b) The kinetics of formation of 9. The curve is the calculated best fit to a single exponential function $\left(k=0.041 \pm 0.001 \mathrm{~min}^{-1}\right.$ and $\left.t_{1 / 2}=16.7 \pm 0.3 \mathrm{~min}\right)$. Data represent average $\pm \mathrm{SD}(\mathrm{n}=3)$. 
(a)

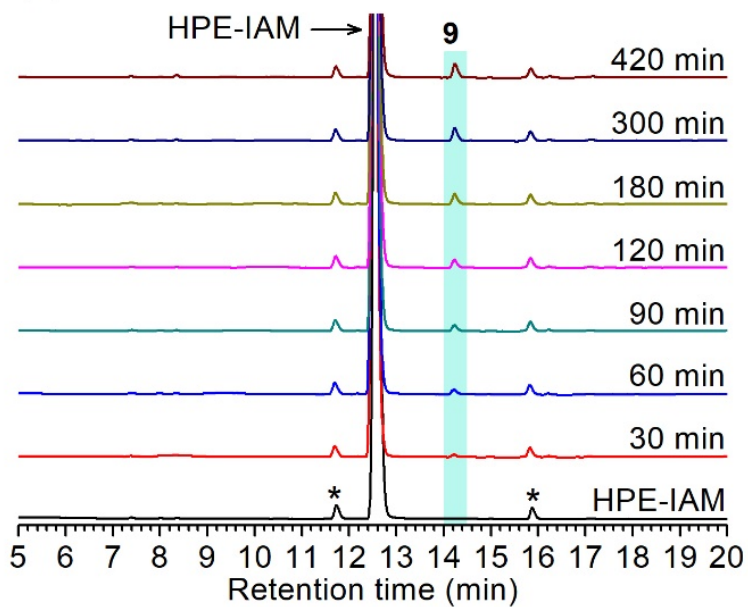

(b)

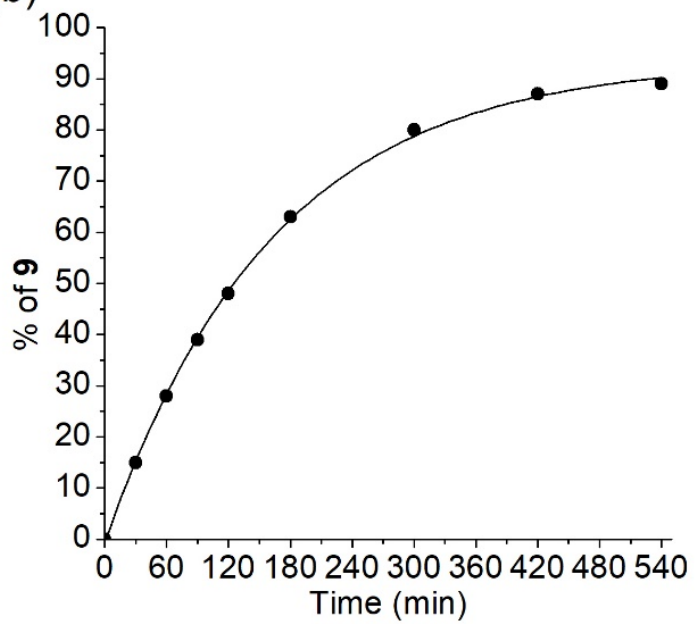

Figure S36. (a) HPLC traces of RSSH generation from 7c $(100 \mu \mathrm{M})$ in the presence of HPE-IAM $(5 \mathrm{mM})$ incubated in $\mathrm{pH} 7.4$ phosphate buffer $(100 \mathrm{mM})$ with DTPA $(100 \mu \mathrm{M})$ at $37^{\circ} \mathrm{C}$. An aliquot of the reaction mixture was withdrawn at specified time points and quenched with $1 \%$ formic acid. The asterisk indicates the presence of small amount of impurities in the commercial HPE-IAM sample. (b) The kinetics of formation of 9. The curve is the calculated best fit to a single exponential function $(k=0.0059 \pm 0.0002$ $\min ^{-1}$ and $\left.t_{1 / 2}=118 \pm 4 \mathrm{~min}\right)$. Data represent average $\pm \operatorname{SD}(\mathrm{n}=3)$.

(a)

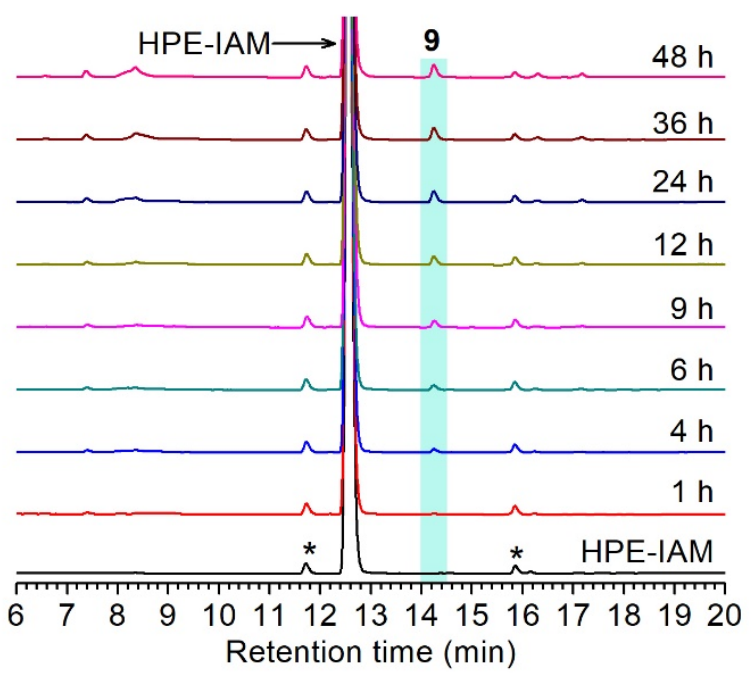

(b)

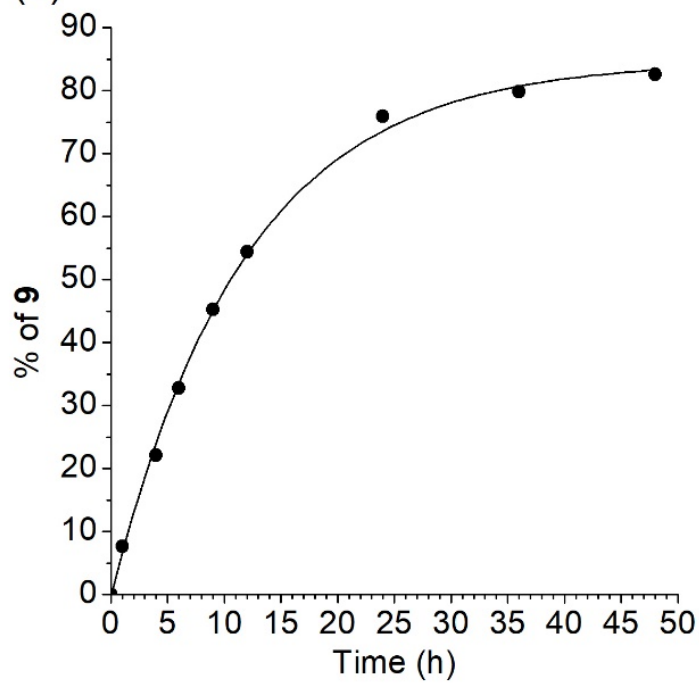

Figure S37. (a) HPLC traces of RSSH generation from 7d $(100 \mu \mathrm{M})$ in the presence of HPE-IAM $(5 \mathrm{mM})$ incubated in $\mathrm{pH} 7.4$ phosphate buffer $(100 \mathrm{mM})$ with DTPA $(100 \mu \mathrm{M})$ at $37^{\circ} \mathrm{C}$. An aliquot of the reaction mixture was withdrawn at specified time points and quenched with $1 \%$ formic acid. The asterisk indicates the presence of small amount of impurities in the commercial HPE-IAM sample. (b) The kinetics of formation of 9. The curve is the calculated best fit to a single exponential function $\left(k=0.086 \pm 0.002 \mathrm{~h}^{-1}\right.$ and $\left.t_{1 / 2}=484 \pm 10 \mathrm{~min}\right)$. Data represent average $\pm \mathrm{SD}(\mathrm{n}=3)$. 


\section{pH effect on the kinetics of RSSH release from $7 \mathrm{a}$ and $7 \mathrm{~b}$}

(a)

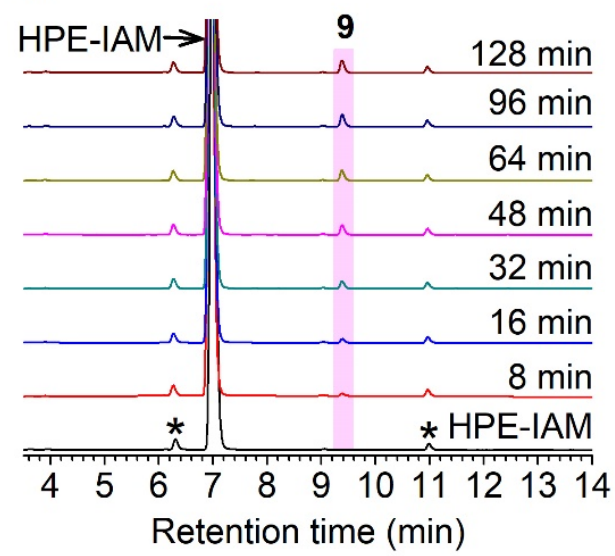

(b)

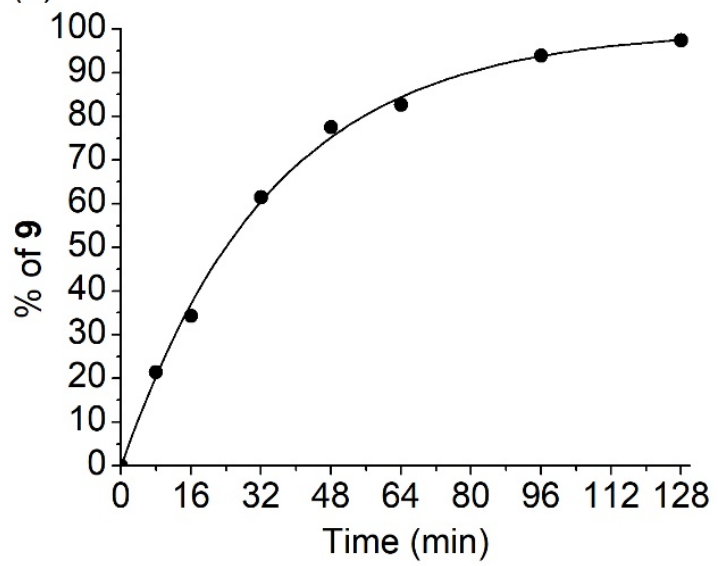

Figure S38. (a) HPLC traces of RSSH generation from 7a $(100 \mu \mathrm{M})$ in the presence of HPE-IAM (5 mM) incubated in pH 6.0 phosphate buffer $(100 \mathrm{mM})$ with DTPA $(100 \mu \mathrm{M})$ at $37^{\circ} \mathrm{C}$. An aliquot of the reaction mixture was withdrawn at specified time points and quenched with $1 \%$ formic acid. The asterisk indicates the presence of small amount of impurities in the commercial HPE-IAM sample. (b) Kinetics of RSS-HPEAM 9 generation from 7a. Data represent average \pm SD $(n=3)$. The curve is the calculated best fit to a single exponential function $\left(k=0.031 \pm 0.002 \mathrm{~min}^{-1}\right.$ and $\left.t_{1 / 2}=22.2 \pm 1.7 \mathrm{~min}\right)$. HPLC analysis was performed with Apollo C-18 reverse phase column $(150 \mathrm{~mm} \times 4.6 \mathrm{~mm}, 5 \mu \mathrm{m})$.

(a)

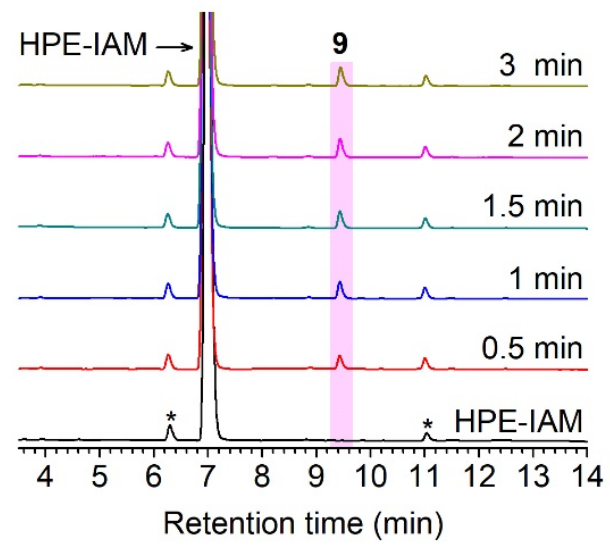

(b)

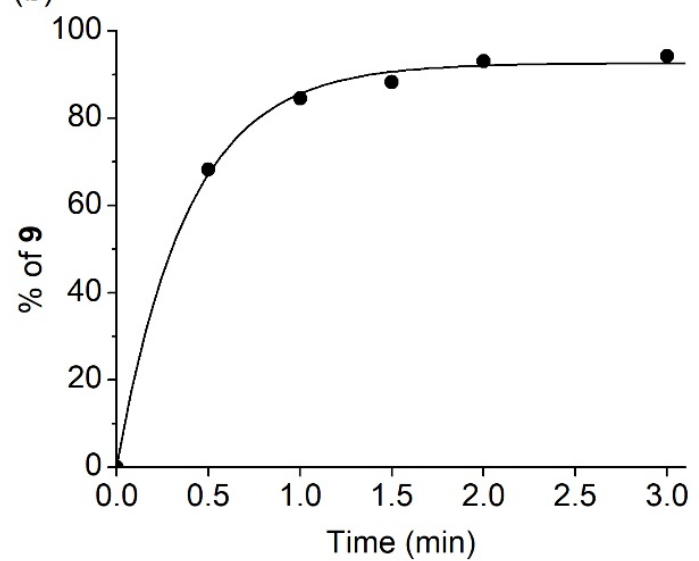

Figure S39. (a) HPLC traces of RSSH generation from 7a $(100 \mu \mathrm{M})$ in the presence of HPE-IAM $(5 \mathrm{mM})$ incubated in $\mathrm{pH} 8.0$ phosphate buffer $(100 \mathrm{mM})$ with DTPA $(100 \mu \mathrm{M})$ at $37^{\circ} \mathrm{C}$. An aliquot of the reaction mixture was withdrawn at specified time points and quenched with $1 \%$ formic acid. The asterisk indicates the presence of small amount of impurities in the commercial HPE-IAM sample. (b) Kinetics of RSS-HPEAM 9 generation from 7a. Data represent average $\pm \mathrm{SD}(\mathrm{n}=3)$. The curve is the calculated best fit to a single exponential function ( $k=2.58 \pm 0.05 \mathrm{~min}^{-1}$ and $\left.t_{1 / 2}=0.27 \pm 0.01 \mathrm{~min}\right)$. HPLC analysis was performed with Apollo C-18 reverse phase column $(150 \mathrm{~mm} \times 4.6 \mathrm{~mm}, 5 \mu \mathrm{m})$. 
(a)

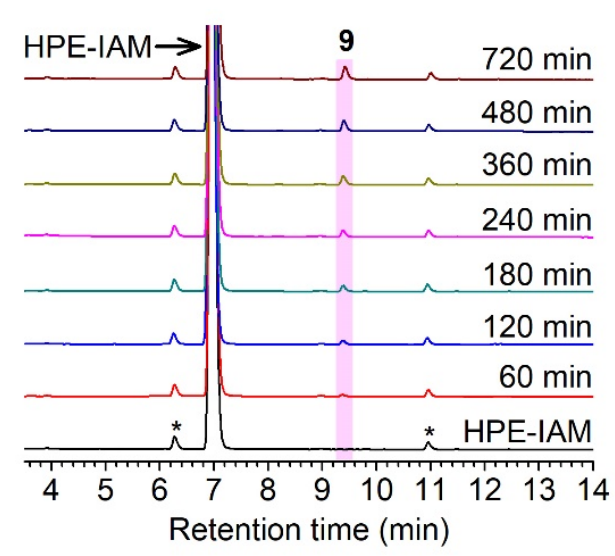

(b)

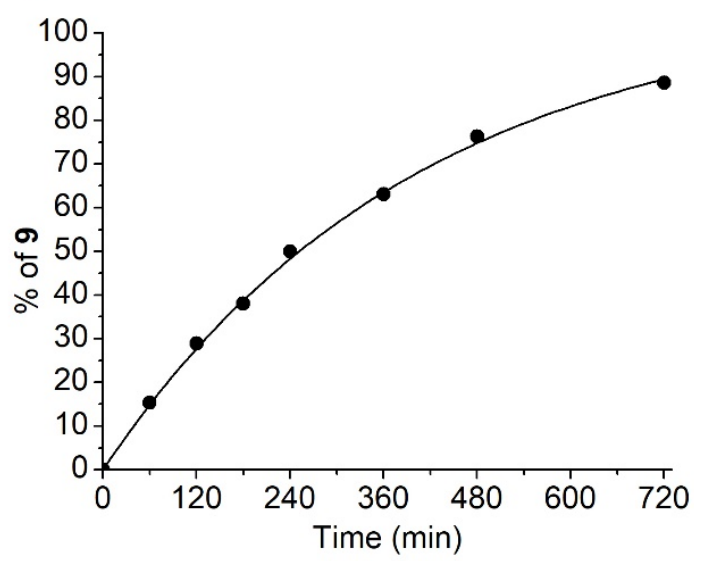

Figure S40. (a) HPLC traces of RSSH generation from $7 \mathbf{b}(100 \mu \mathrm{M})$ in the presence of HPE-IAM $(5 \mathrm{mM})$ incubated in $\mathrm{pH} 6.0$ phosphate buffer $(100 \mathrm{mM})$ with DTPA $(100 \mu \mathrm{M})$ at $37^{\circ} \mathrm{C}$. An aliquot of the reaction mixture was withdrawn at specified time points and quenched with $1 \%$ formic acid. The asterisk indicates the presence of small amount of impurities in the commercial HPE-IAM sample. (b) Kinetics of RSS-HPEAM 9 generation from 7b. Data represent average $\pm \mathrm{SD}(\mathrm{n}=3)$. The curve is the calculated best fit to a single exponential function $\left(k=0.0025 \pm 0.0000 \mathrm{~min}^{-1}\right.$ and $\left.t_{1 / 2}=280 \pm 3 \mathrm{~min}\right)$. HPLC analysis was performed with Apollo C-18 reverse phase column $(150 \mathrm{~mm} \times 4.6 \mathrm{~mm}, 5 \mu \mathrm{m})$.

(a)

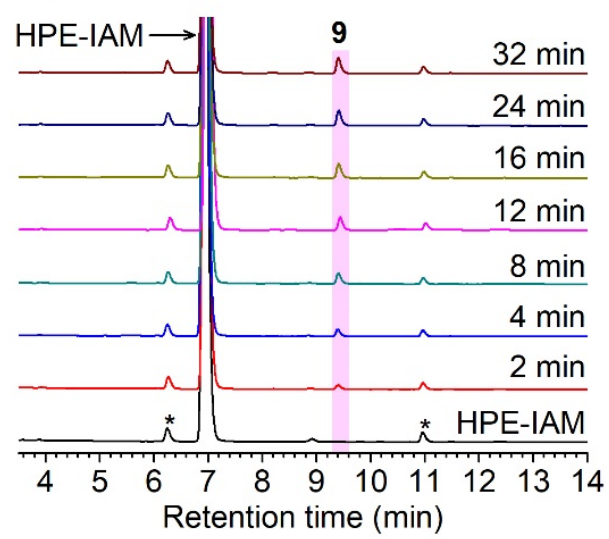

(b)

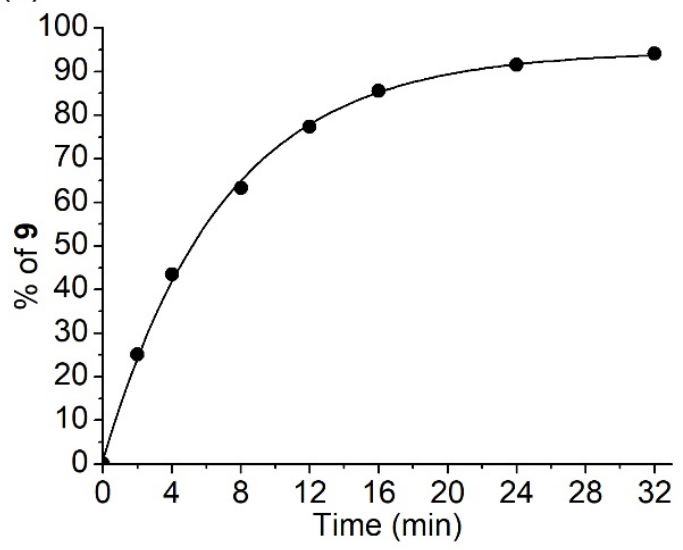

Figure S41. (a) HPLC traces of RSSH generation from $7 \mathbf{b}(100 \mu \mathrm{M})$ in the presence of HPE-IAM $(5 \mathrm{mM})$ incubated in $\mathrm{pH} 8.0$ phosphate buffer $(100 \mathrm{mM})$ with DTPA $(100 \mu \mathrm{M})$ at $37^{\circ} \mathrm{C}$. An aliquot of the reaction mixture was withdrawn at specified time points and quenched with $1 \%$ formic acid. The Asterisk indicates the presence of small amount of impurities in the commercial HPE-IAM sample. (b) Kinetics of RSS-HPEAM 9 generation from $\mathbf{7 b}$. Data represent average \pm SD $(n=3)$. The curve is the calculated best fit to a single exponential function $\left(k=0.136 \pm 0.007 \mathrm{~min}^{-1}\right.$ and $\left.t_{1 / 2}=5.1 \pm 0.3 \mathrm{~min}\right)$. HPLC analysis was performed with Apollo C-18 reverse phase column $(150 \mathrm{~mm} \times 4.6 \mathrm{~mm}, 5 \mu \mathrm{m})$. 


\section{Kinetics of decomposition of 7 a and formation of 9 and $2 a$}

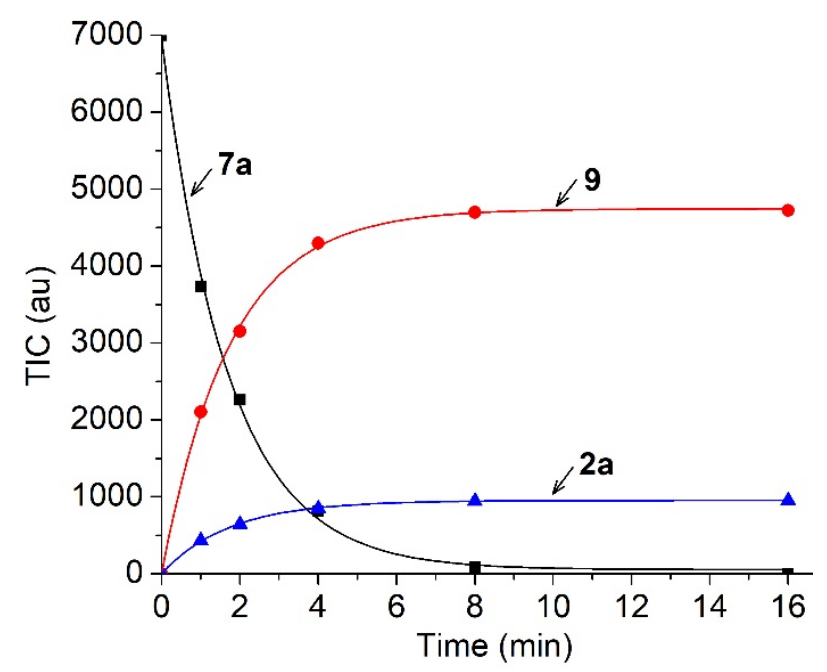

Figure S42. Kinetics of decomposition of $7 \mathbf{a}(20 \mu \mathrm{M})$ in the presence of HPE-IAM $(1 \mathrm{mM})$ and formation of $\mathbf{2 a}$ and 9 in ammonium bicarbonate buffer $(50 \mathrm{mM})$ with DTPA $(100 \mu \mathrm{M})$ analyzed using UPLC-MS. An aliquot of the reaction mixture was withdrawn at the specified time and quenched with $1 \%$ formic acid. The curves are the calculated best fits to a single-exponential function. The pseudo-first order rate constants for 7a, 9 and $\mathbf{2 a}$ are $0.59 \pm 0.02,0.57 \pm 0.02$, and $0.58 \pm 0.03 \mathrm{~min}^{-1}$, respectively.

\section{Analysis of RSSH generation from 7 a-d in the presence of $\boldsymbol{N}$-acetyl cysteine by UPLC-MS}

To a solution of $N$-acetyl cysteine (NAC, $500 \mu \mathrm{M})$ in $\mathrm{pH} 7.4$ ammonium bicarbonate buffer (50 $\mathrm{mM})$ containing DTPA $(100 \mu \mathrm{M})$, precursors 7a-d $(100 \mu \mathrm{M})$ were independently added. The resulting mixture was incubated at $37^{\circ} \mathrm{C}$. An aliquot $(200 \mu \mathrm{L})$ of reaction mixture was withdrawn at specified time points and quenched with $1 \%$ formic acid $(200 \mu \mathrm{L})$. 3-Amino-benzoic acid (50 $\mu \mathrm{M}$ ) was added to each sample as internal standard prior to UPLC-MS analysis. To quantify 2ad generated from these precursors, we independently generated a calibration curve for each individual cyclic urea with known concentrations. 


\section{HRMS spectra of products obtained during incubation of 7a with NAC}

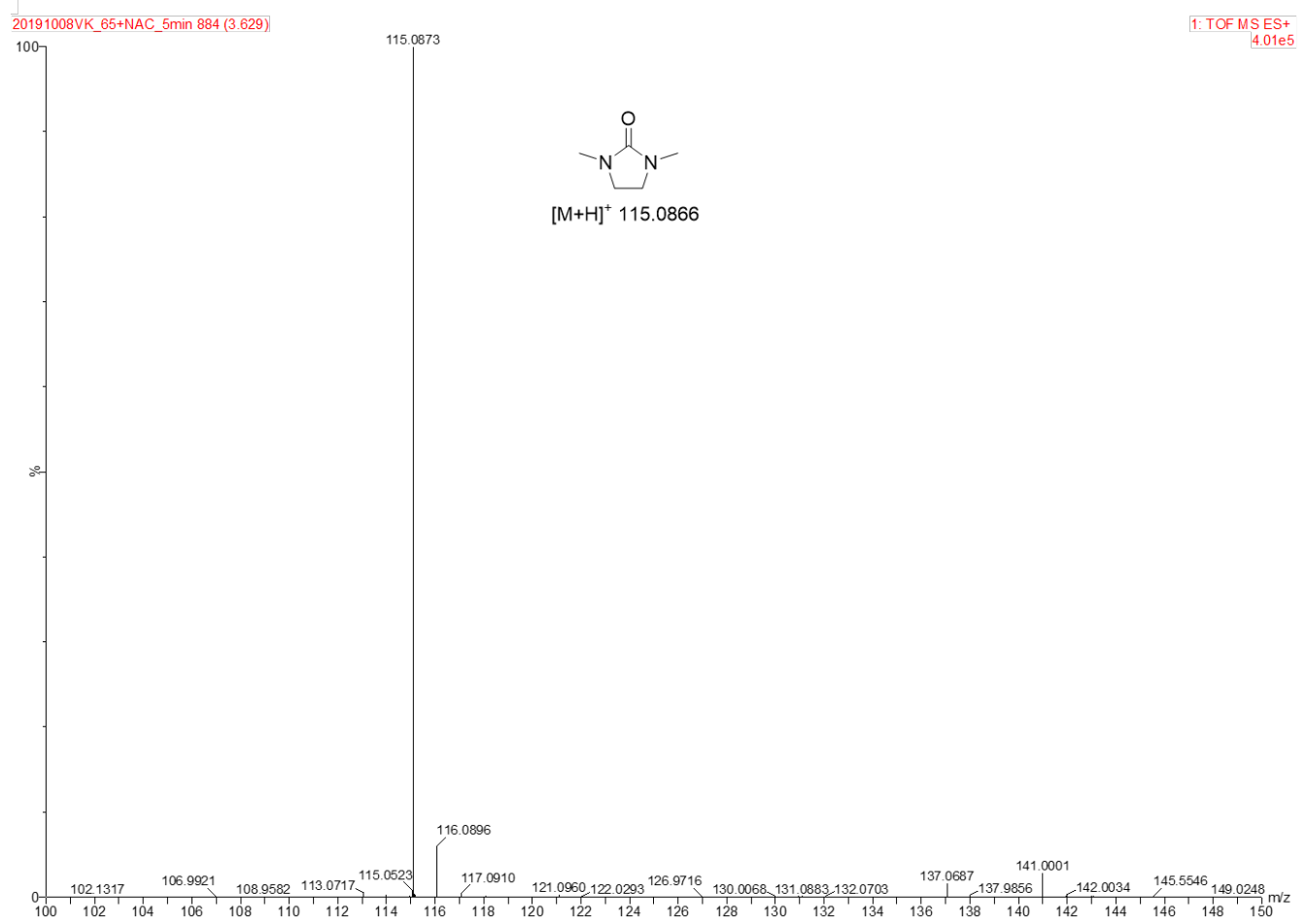

Figure S43. HRMS of the peak eluting at 3.63 min corresponding to byproduct 2a.

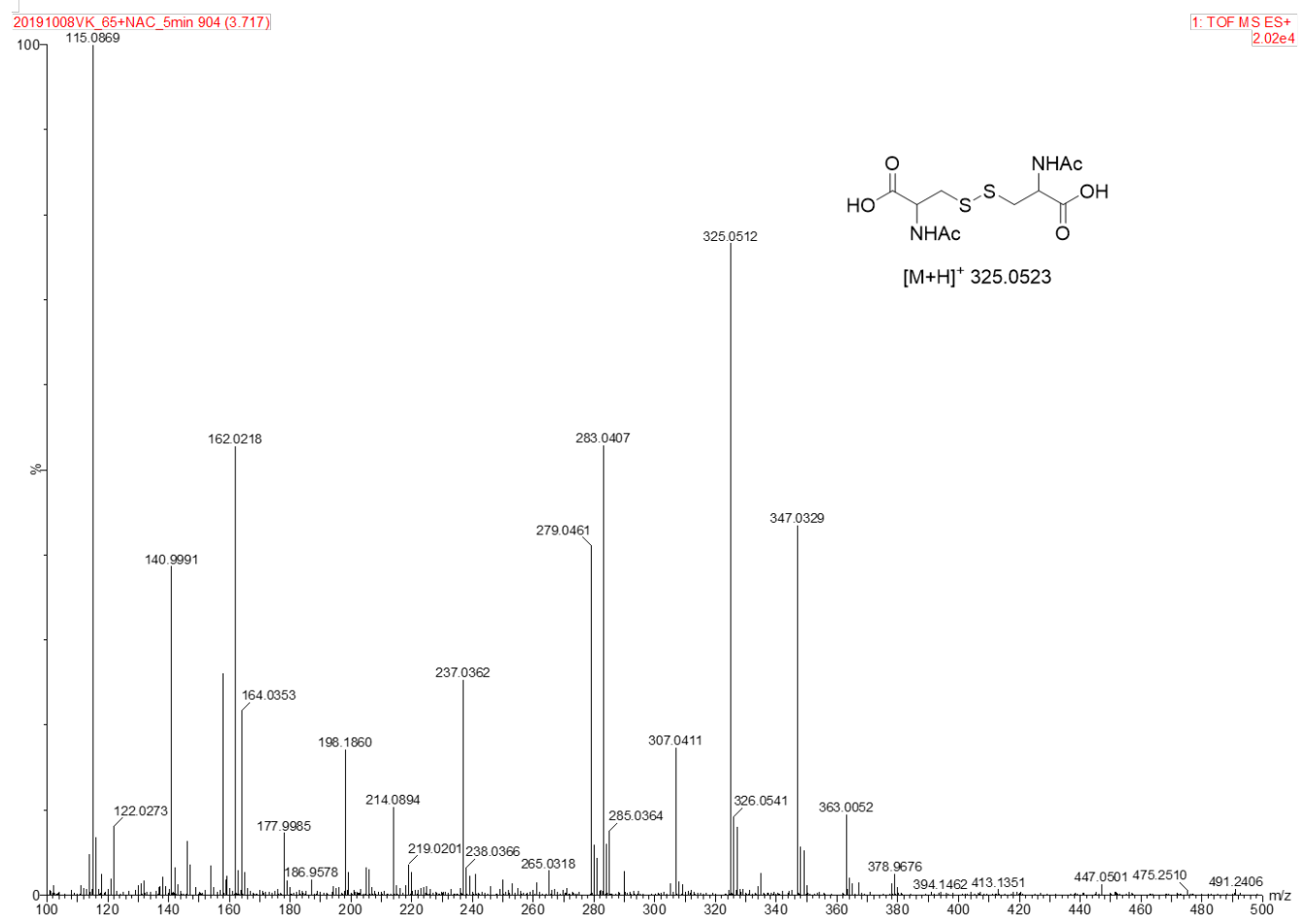

Figure S44. HRMS of the peak eluting at 3.72 min corresponding to $N$-acetyl cystine. 


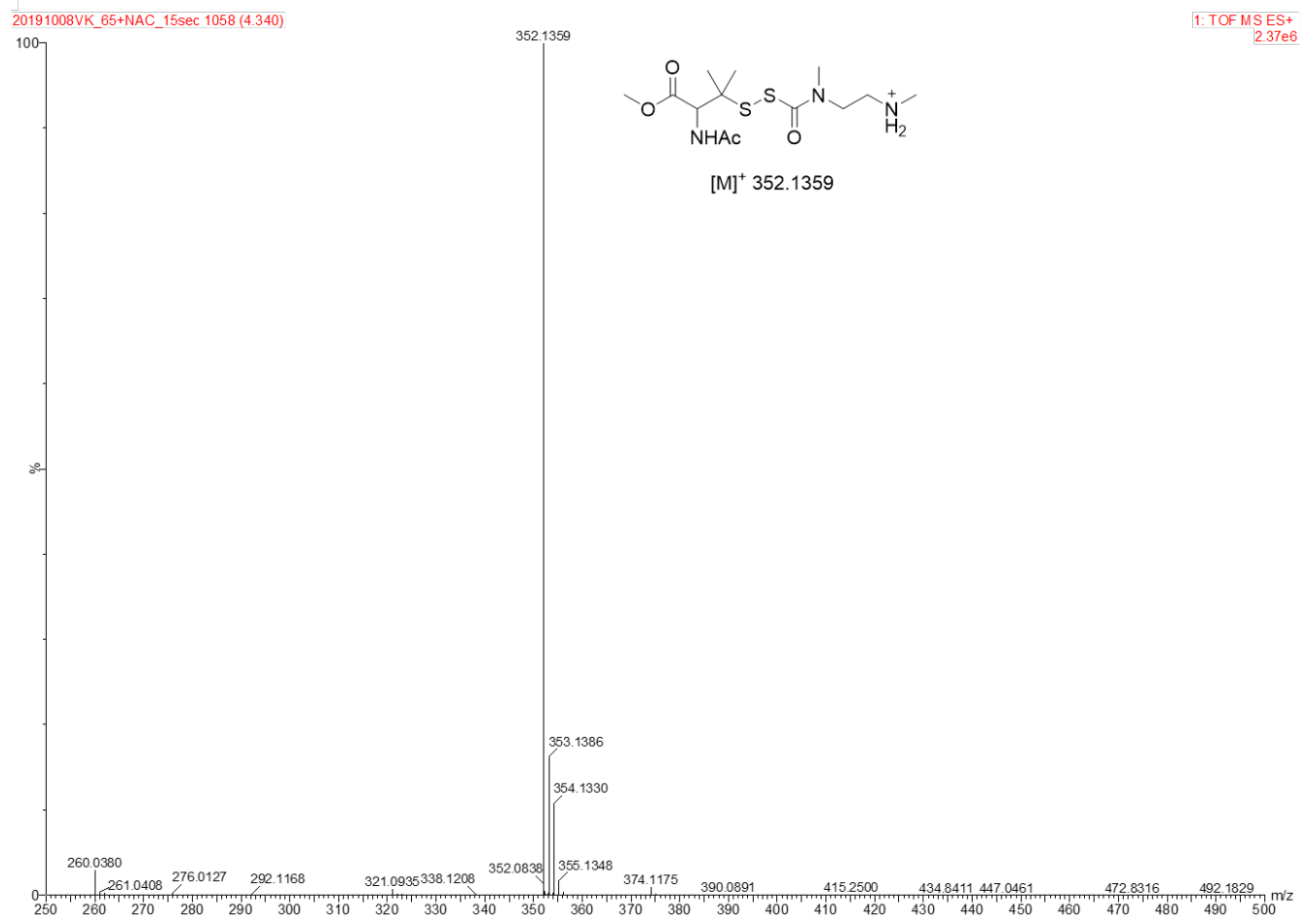

Figure S45. HRMS of the peak eluting at 4.34 min corresponding to precursor $7 \mathbf{a}$.

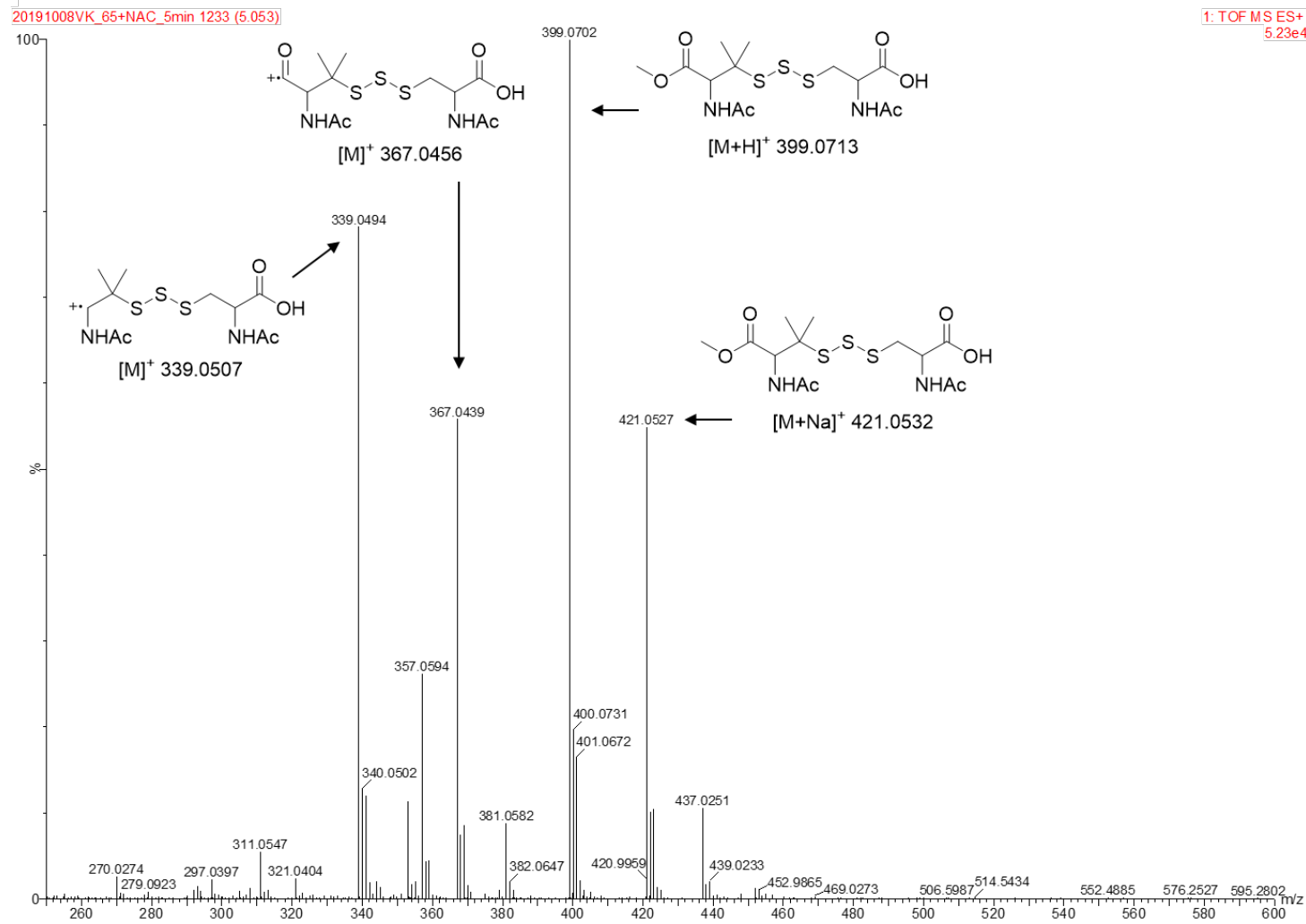

Figure S46. HRMS of the peak eluting at 5.05 min corresponding to unsymmetrical trisulfide $\left(\mathrm{R}^{1} \mathrm{SSSR}^{3}\right)$. 


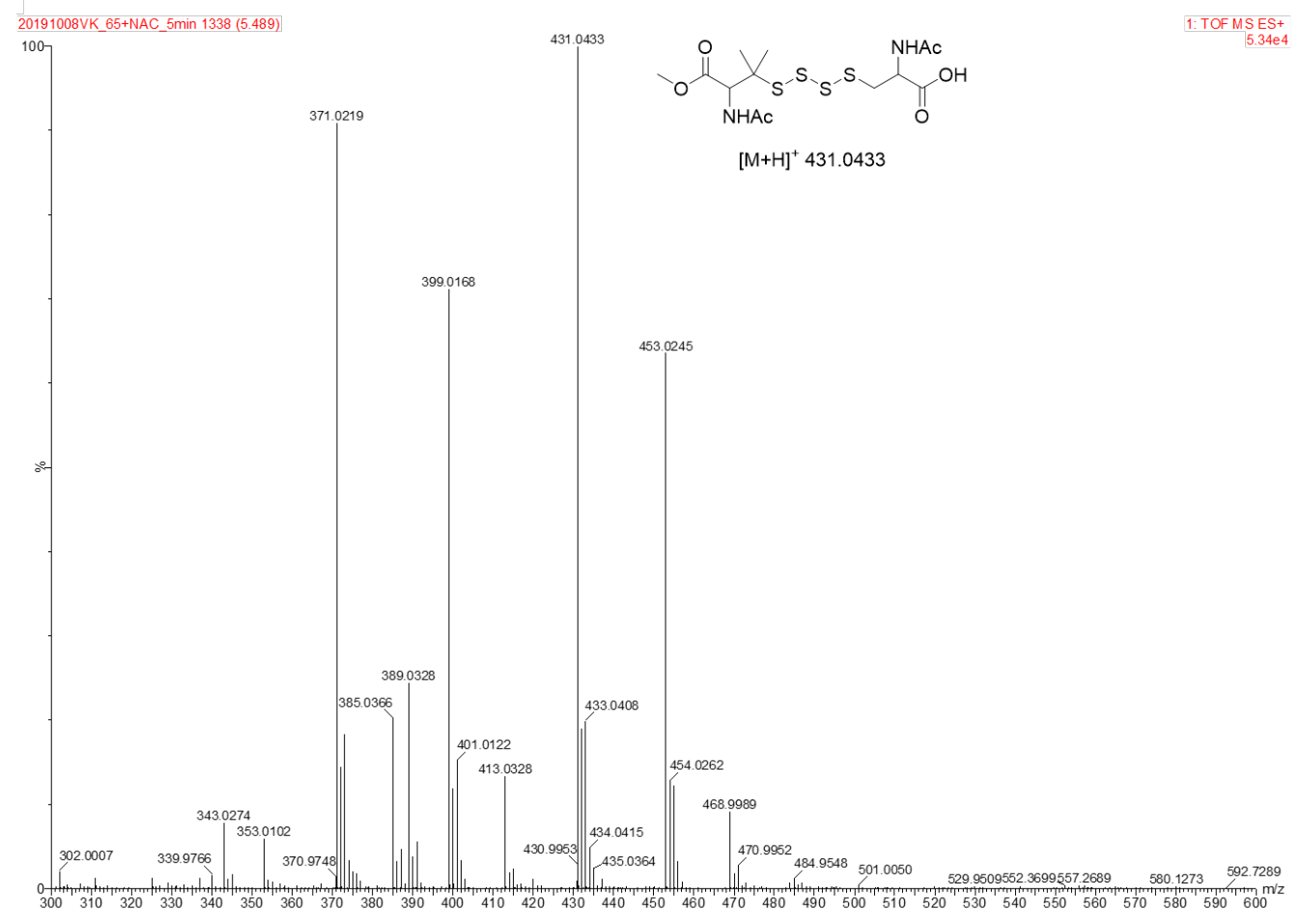

Figure S47. HRMS of the peak eluting at 5.49 min corresponding to unsymmetrical tetrasulfide $\left(\mathrm{R}^{1} \mathrm{SS}_{2} \mathrm{SR}^{3}\right)$.

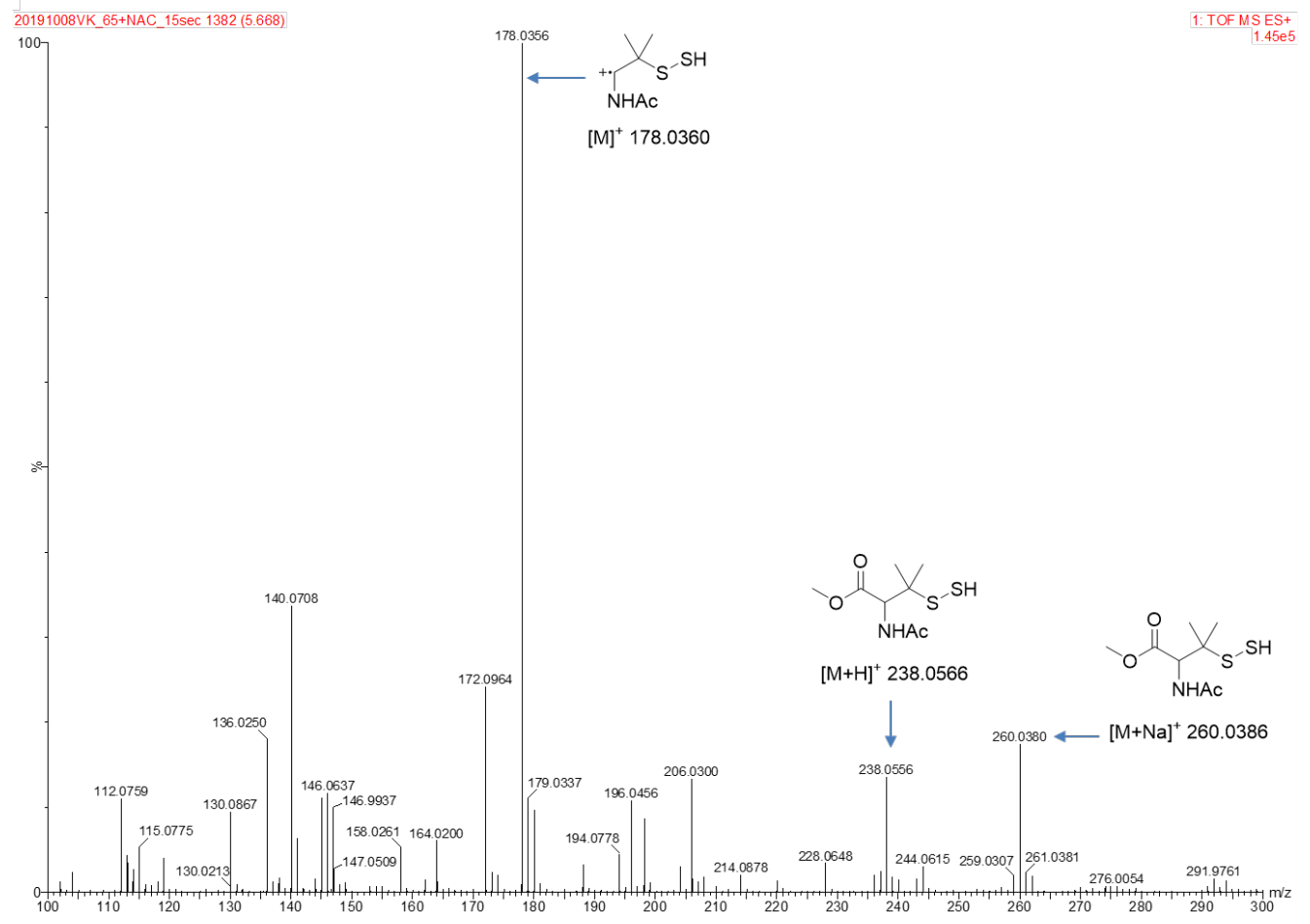

Figure S48. HRMS of the peak eluting at 5.67 min corresponding to ${ }^{1} \mathrm{SSH}$. 


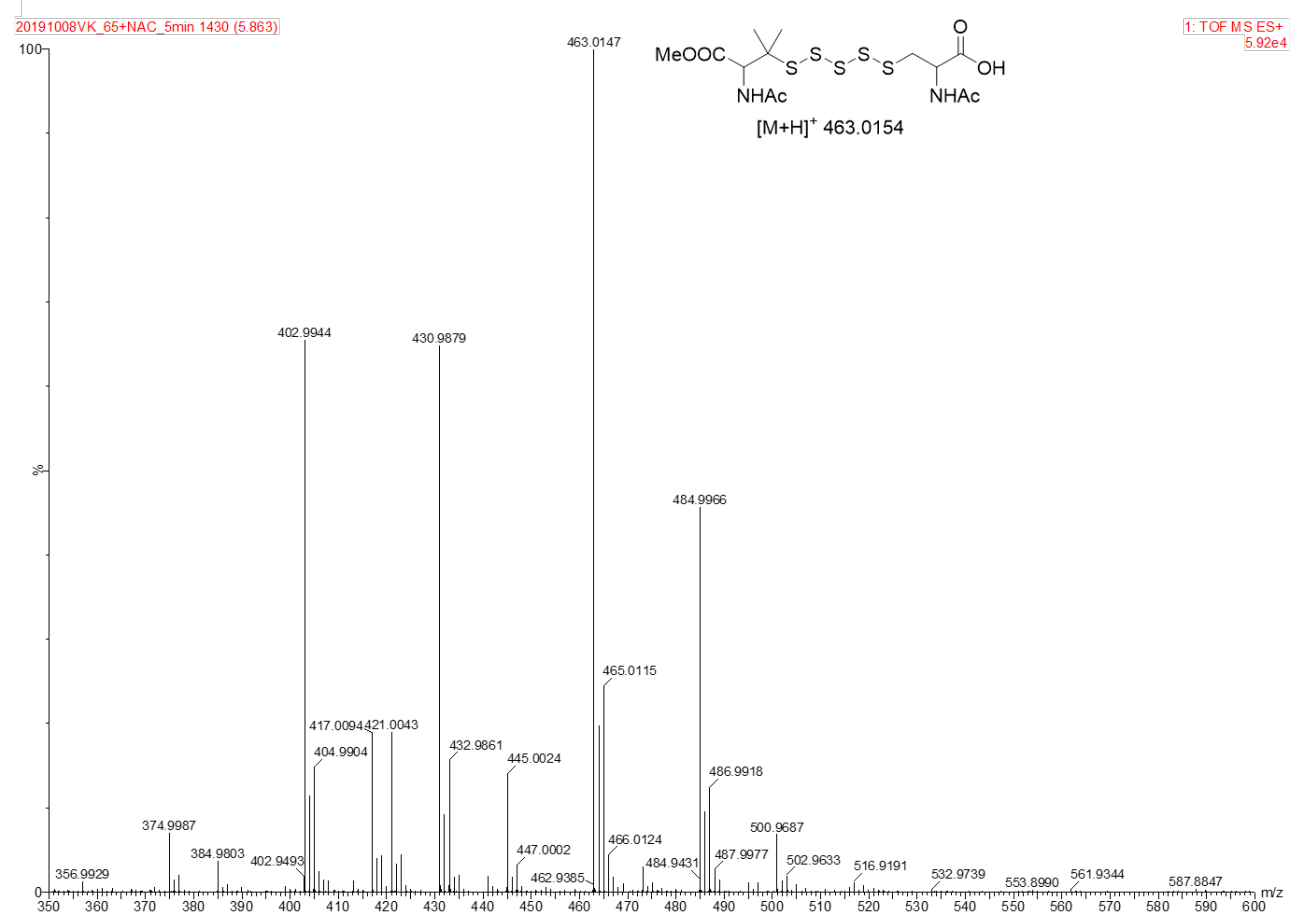

Figure S49. HRMS of the peak eluting at $5.86 \mathrm{~min}$ corresponding to unsymmetrical pentasulfide $\left(\mathrm{R}^{1} \mathrm{SS}_{3} \mathrm{SR}^{3}\right)$.

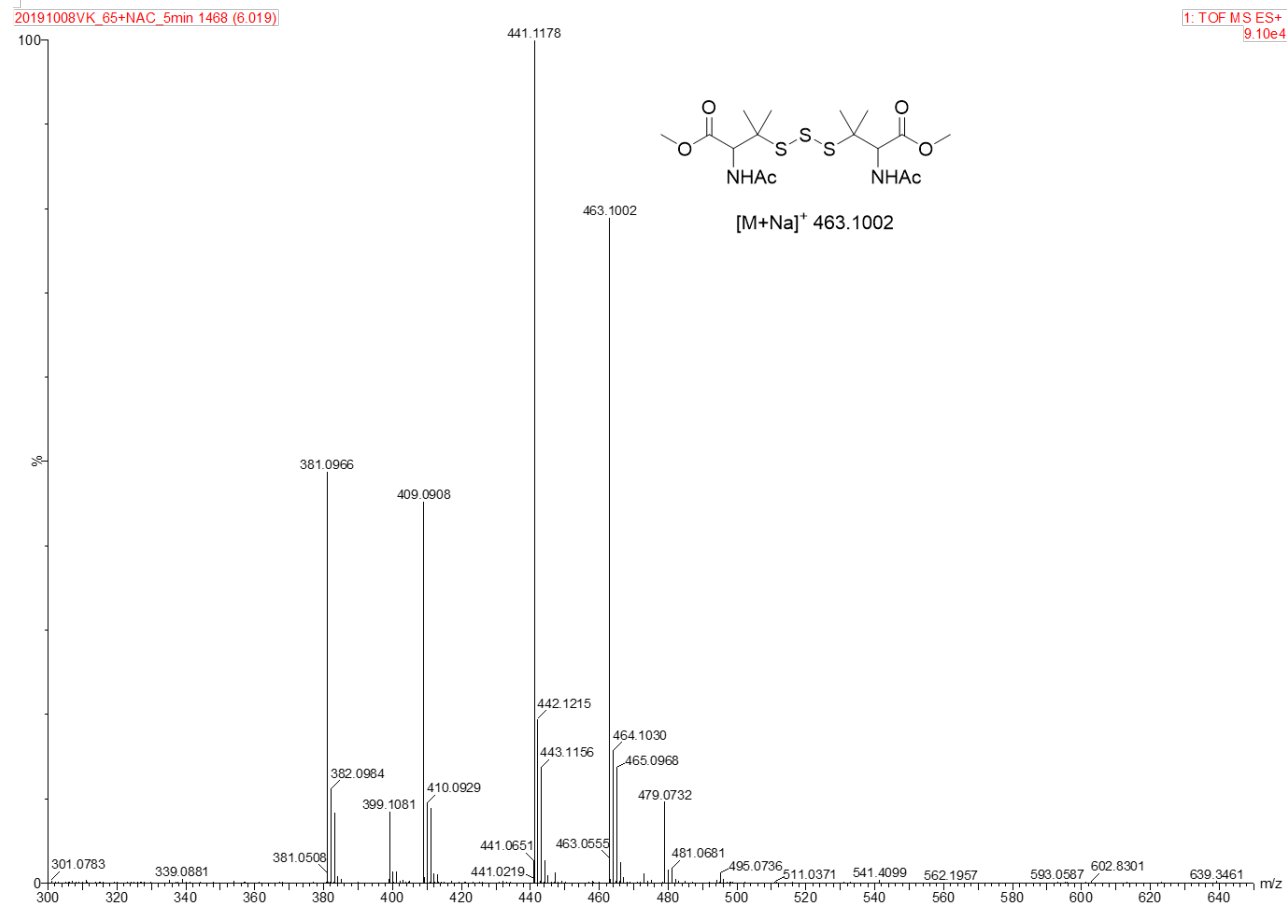

Figure S50. HRMS of the peak eluting at 6.02 min corresponding to symmetrical trisulfide $\left(\mathrm{R}^{1} \mathrm{SSSR}^{1}\right)$. 


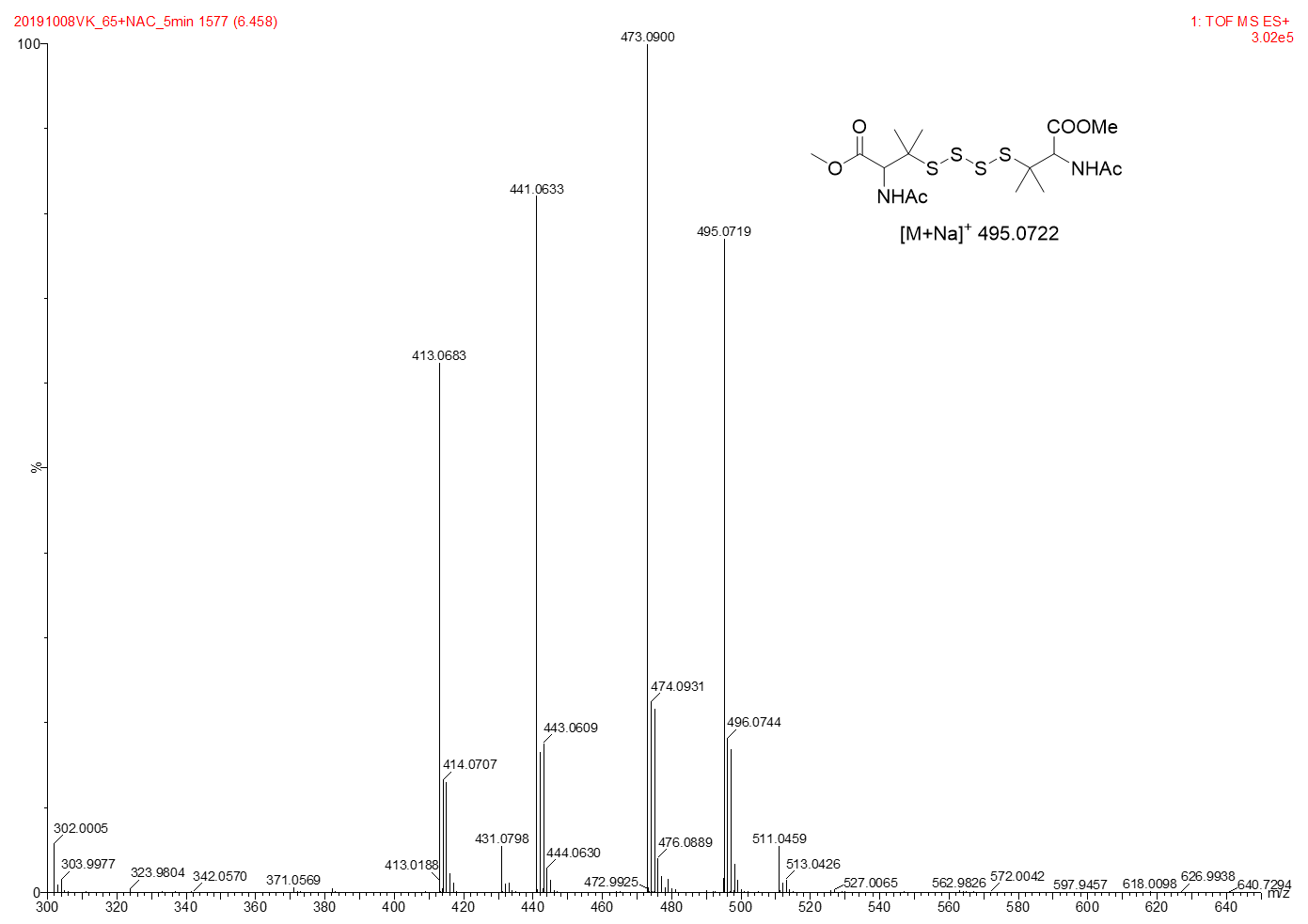

Figure S51. HRMS of the peak eluting at 6.46 min corresponding to symmetrical tetrasulfide $\left(\mathrm{R}^{1} \mathrm{SS}_{2} \mathrm{SR}^{1}\right)$.

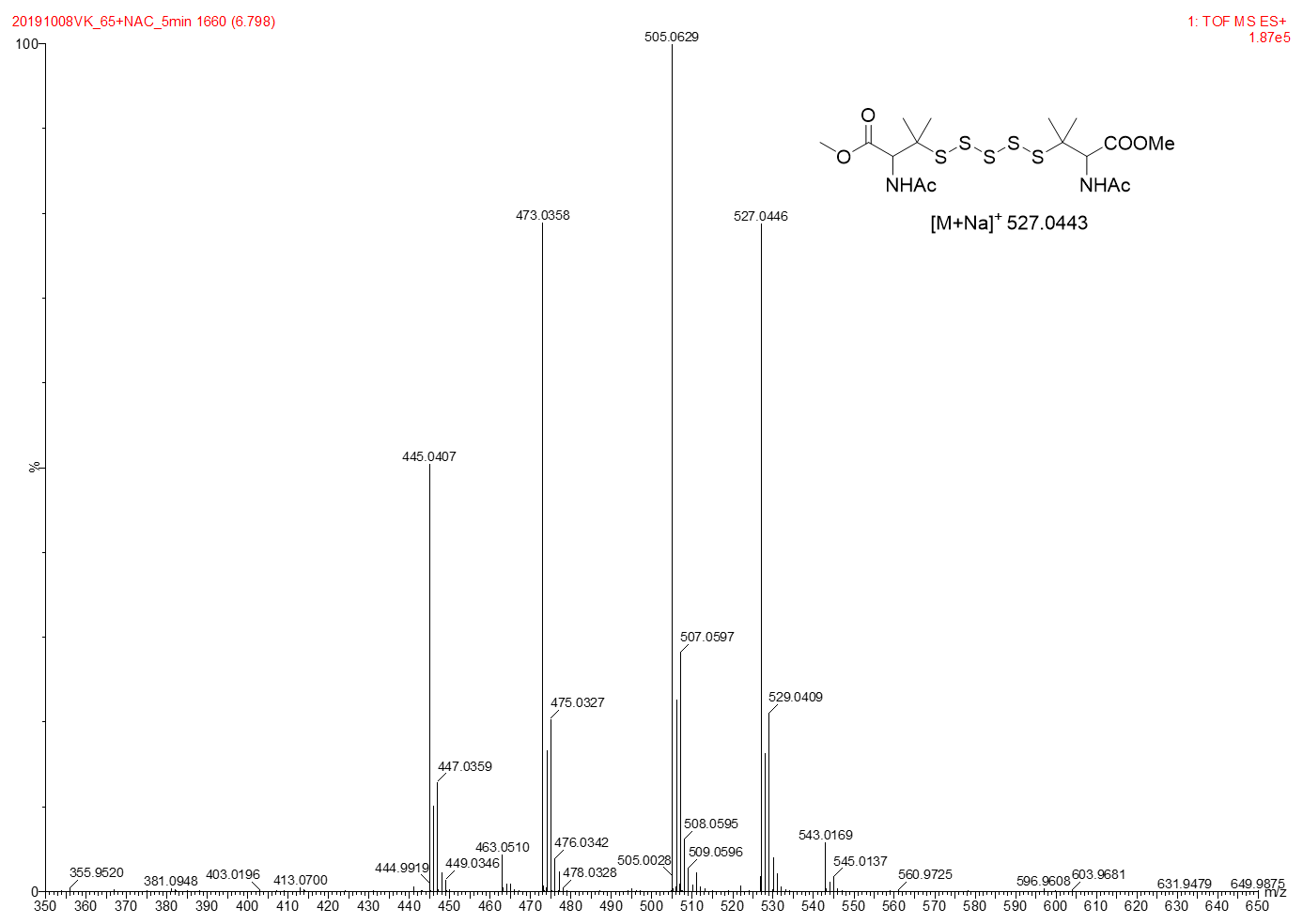

Figure S52. HRMS of the peak eluting at 6.80 min corresponding to symmetrical pentasulfide $\left(\mathrm{R}^{1} \mathrm{SS}_{3} \mathrm{SR}^{1}\right)$. 


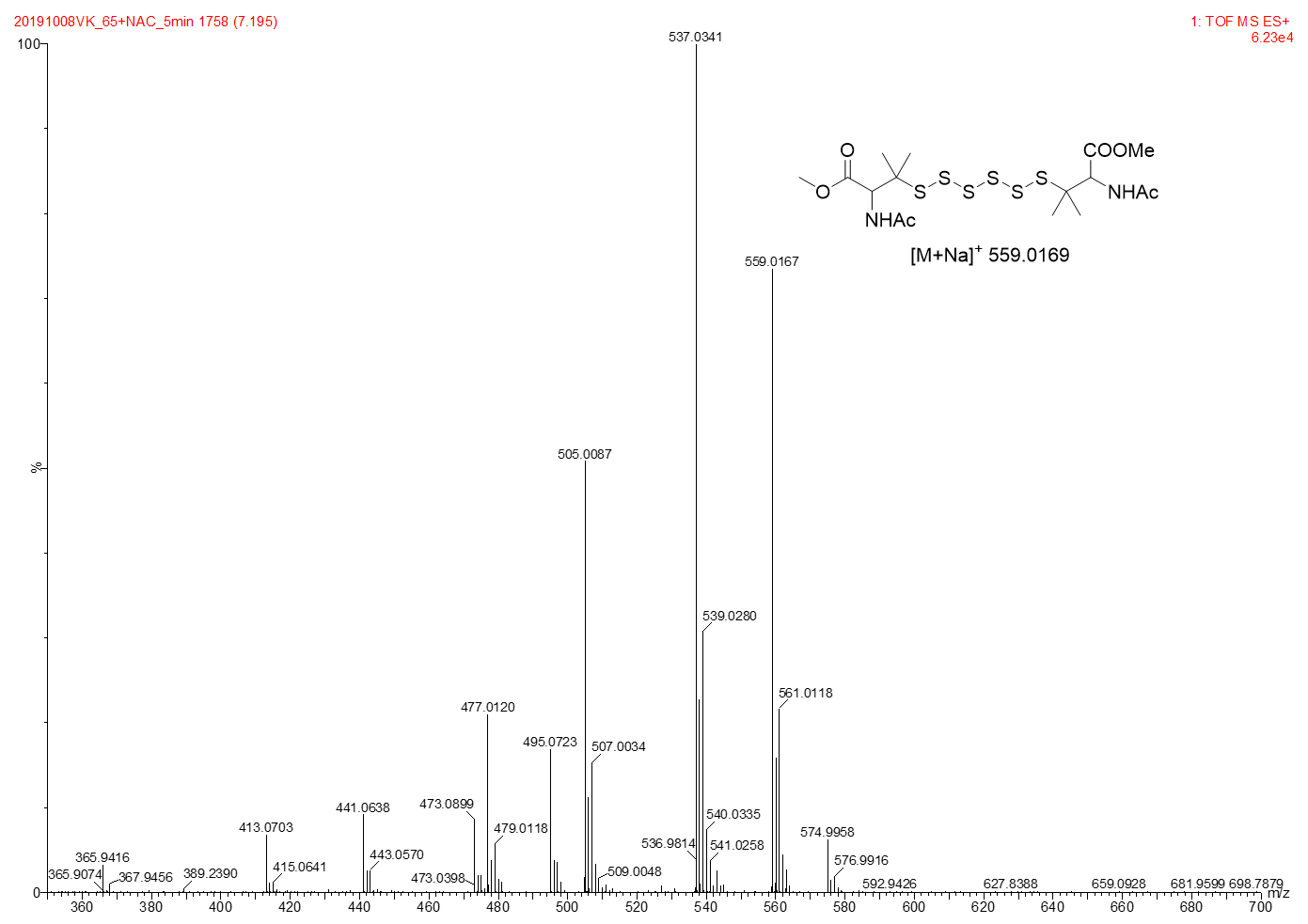

Figure S53. HRMS of the peak eluting at $7.20 \mathrm{~min}$ corresponding to symmetrical hexasulfide $\left(\mathrm{R}^{1} \mathrm{SS}_{4} \mathrm{SR}^{1}\right)$.

\section{Decomposition of precursor $7 \mathrm{a}$ in the absence of a trapping agent}

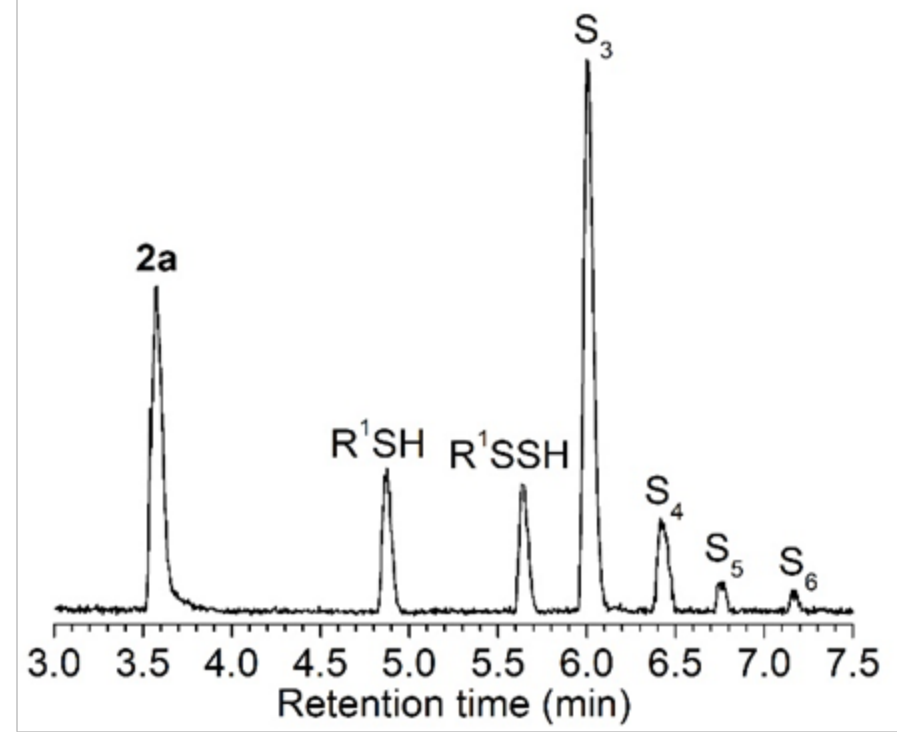

Figure S54. RSSH generation from 7a $(100 \mu \mathrm{M})$ in the absence of HPE-IAM in pH 7.4 ammonium bicarbonate buffer with DTPA $(100 \mu \mathrm{M})$ at $37^{\circ} \mathrm{C}$ for $10 \mathrm{~min}$. RSSH and RSSH-derived symmetrical dialkyl polysulfides (labeled as $\mathrm{S}_{2}$ to $\mathrm{S}_{6}$ ) formation were observed under these conditions. 


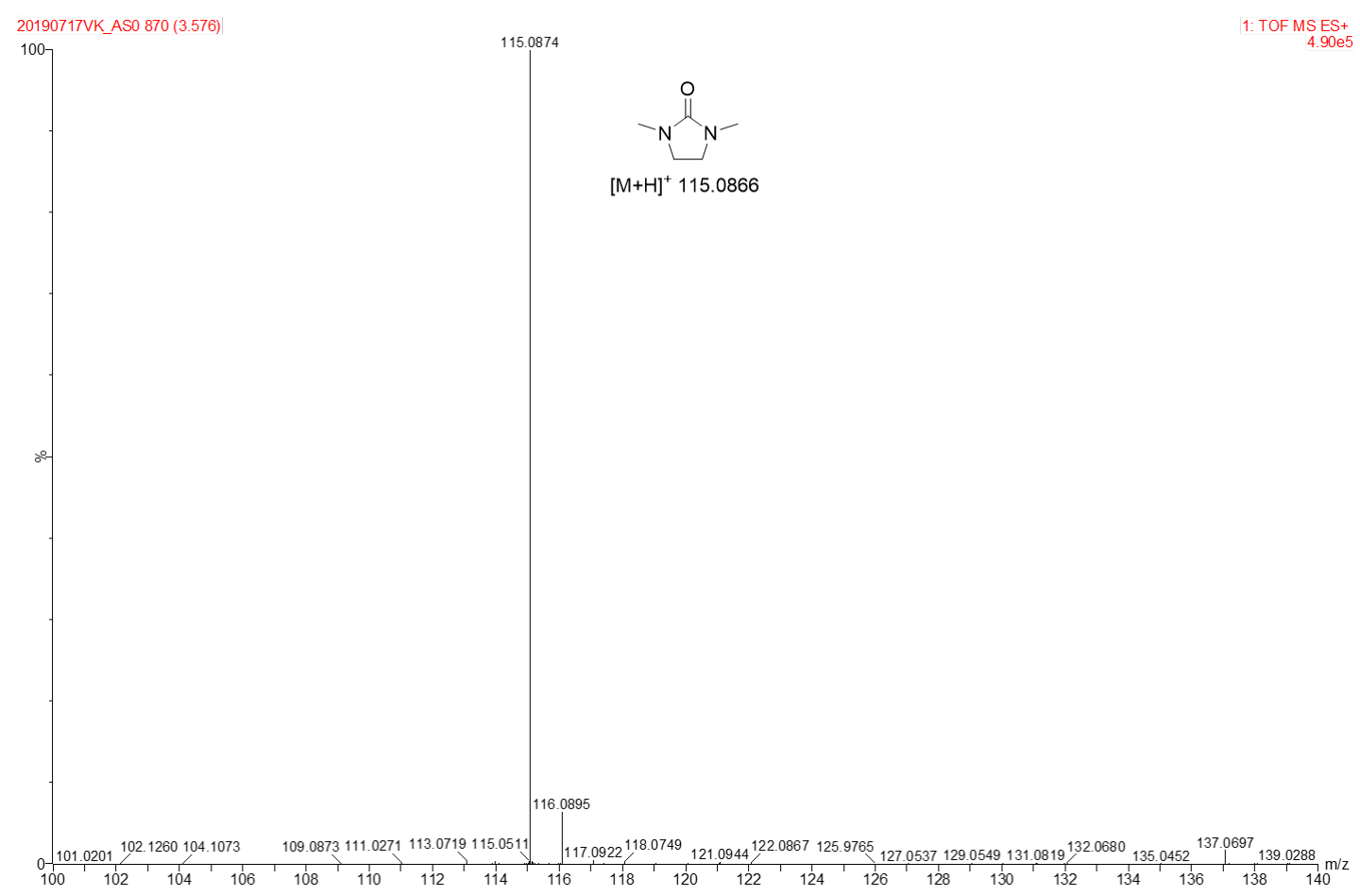

Figure S55. HRMS of the peak eluting at 3.57 min corresponding to byproduct 2a.

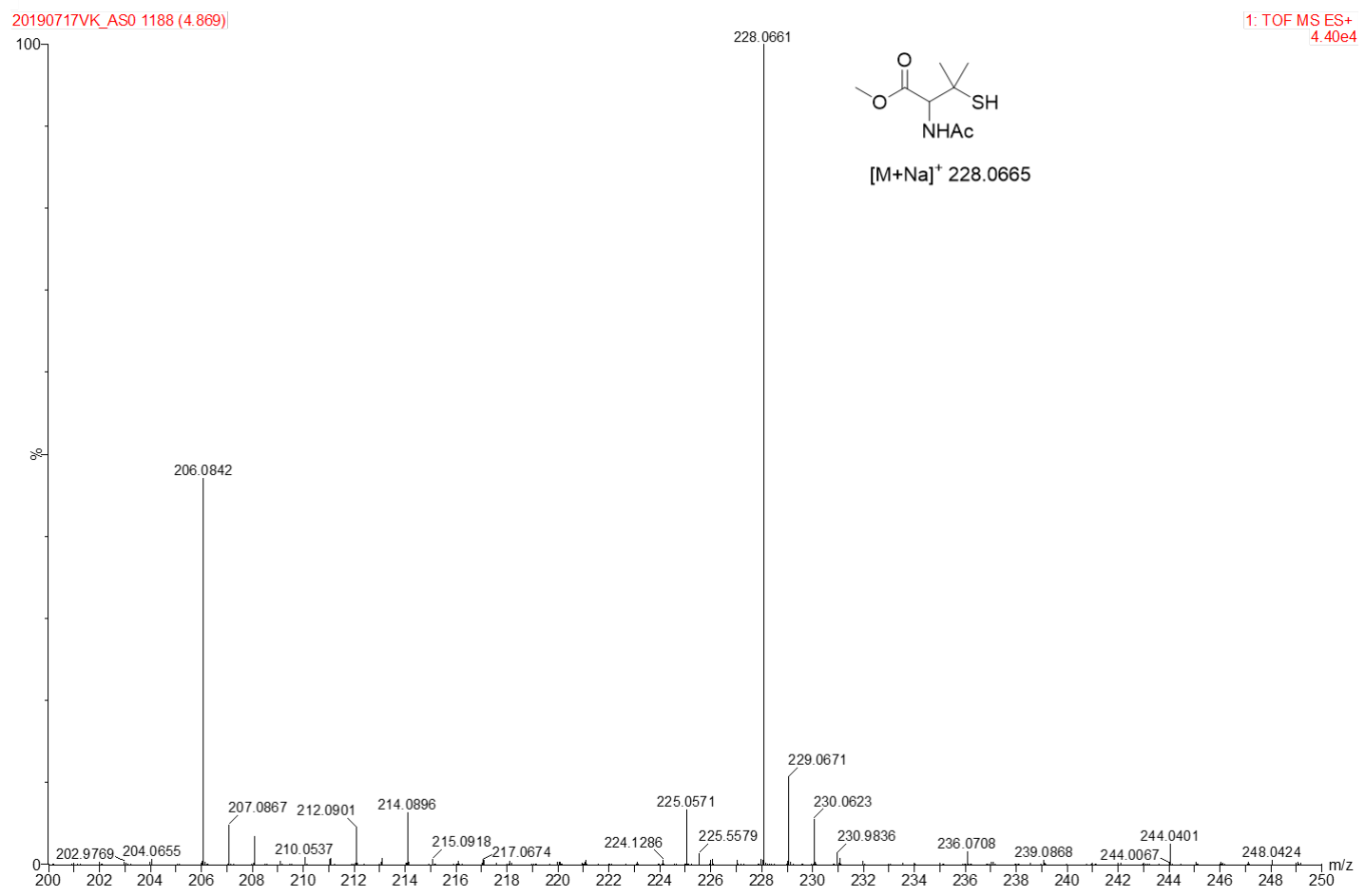

Figure S56. HRMS of the peak eluting at 4.87 min corresponding to $N$-acetyl-penicillamine-methyl ester. 


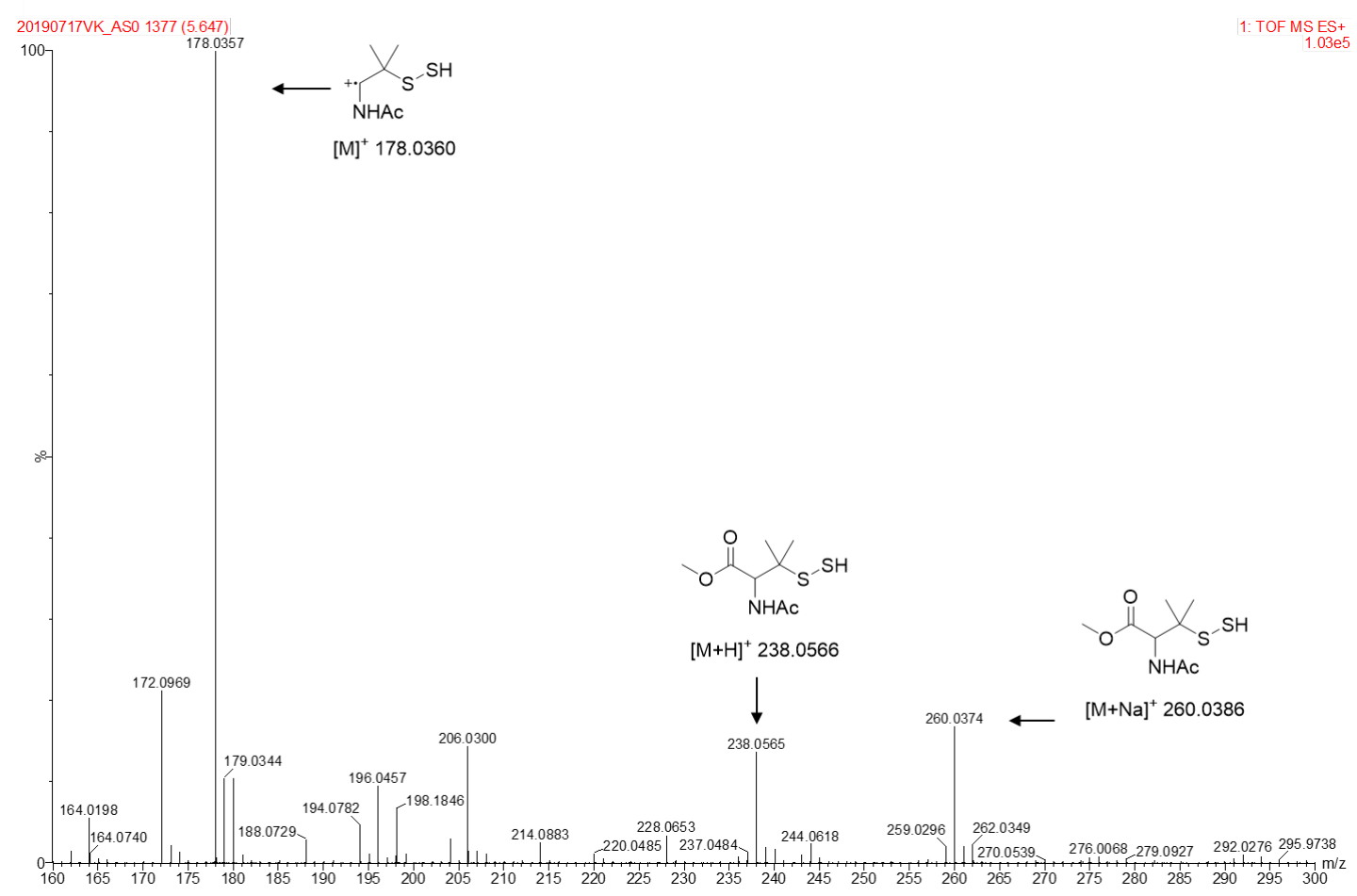

Figure S57. HRMS of the peak eluting at $5.67 \mathrm{~min}$ corresponding to $\mathrm{R}^{1} \mathrm{SSH}$.

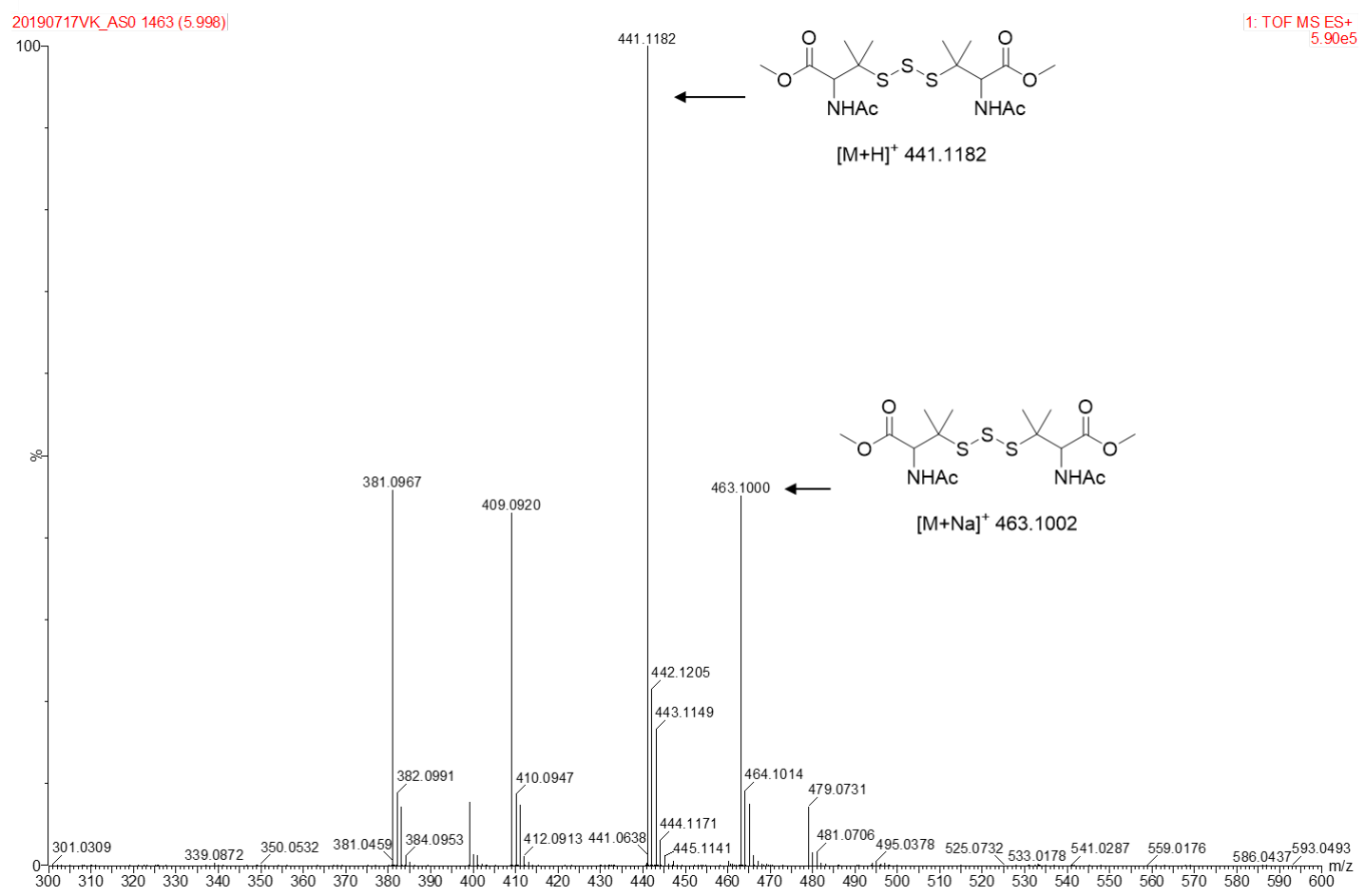

Figure S58. HRMS of the peak eluting at 6.0 min corresponding to symmetrical trisulfide $\left(\mathrm{R}^{1} \mathrm{SSSR}^{1}\right)$. 


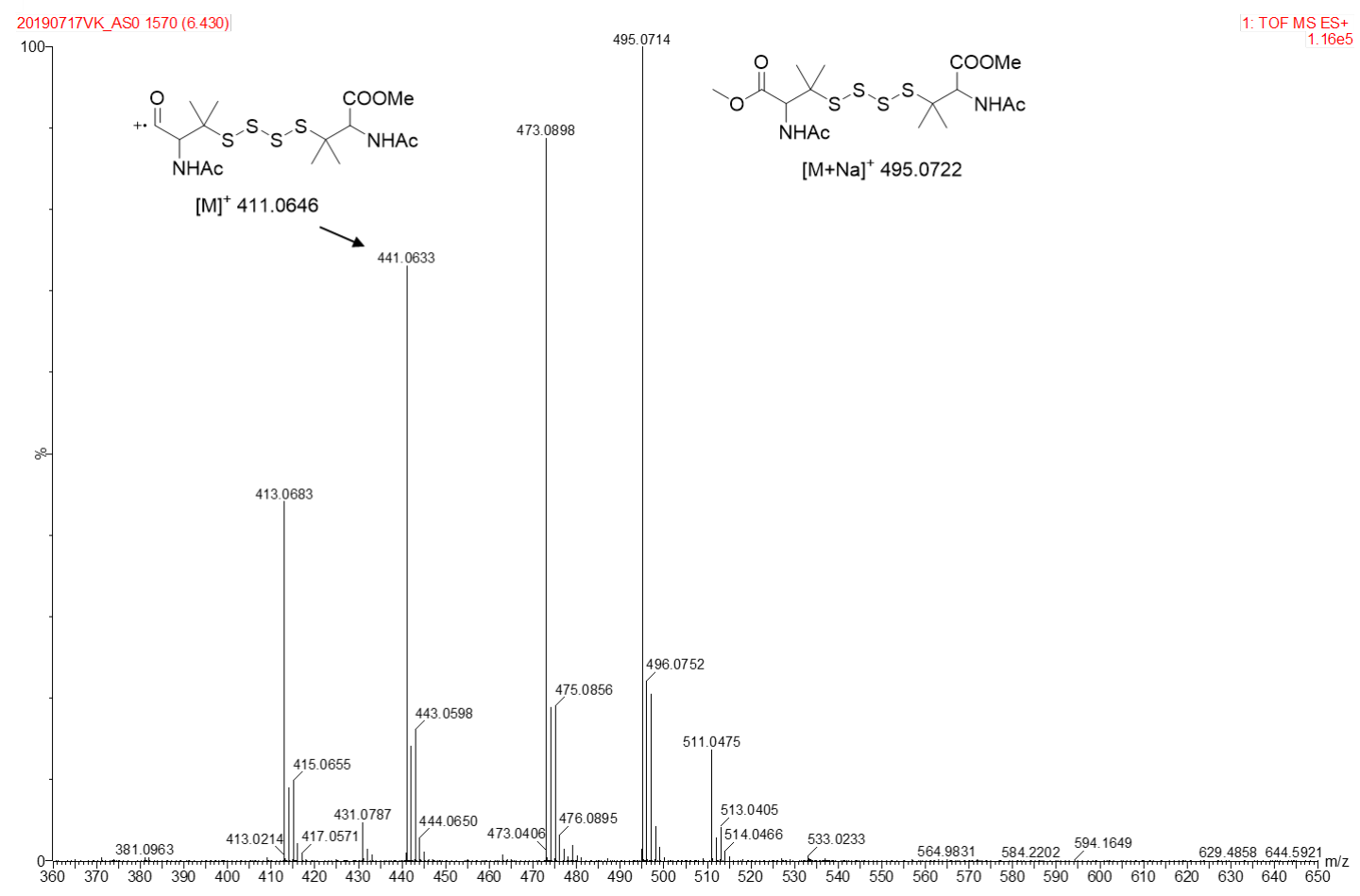

Figure S59. HRMS of the peak eluting at 6.43 min corresponding to symmetrical tetrasulfide $\left(\mathrm{R}^{1} \mathrm{SS}_{2} \mathrm{SR}^{1}\right)$.

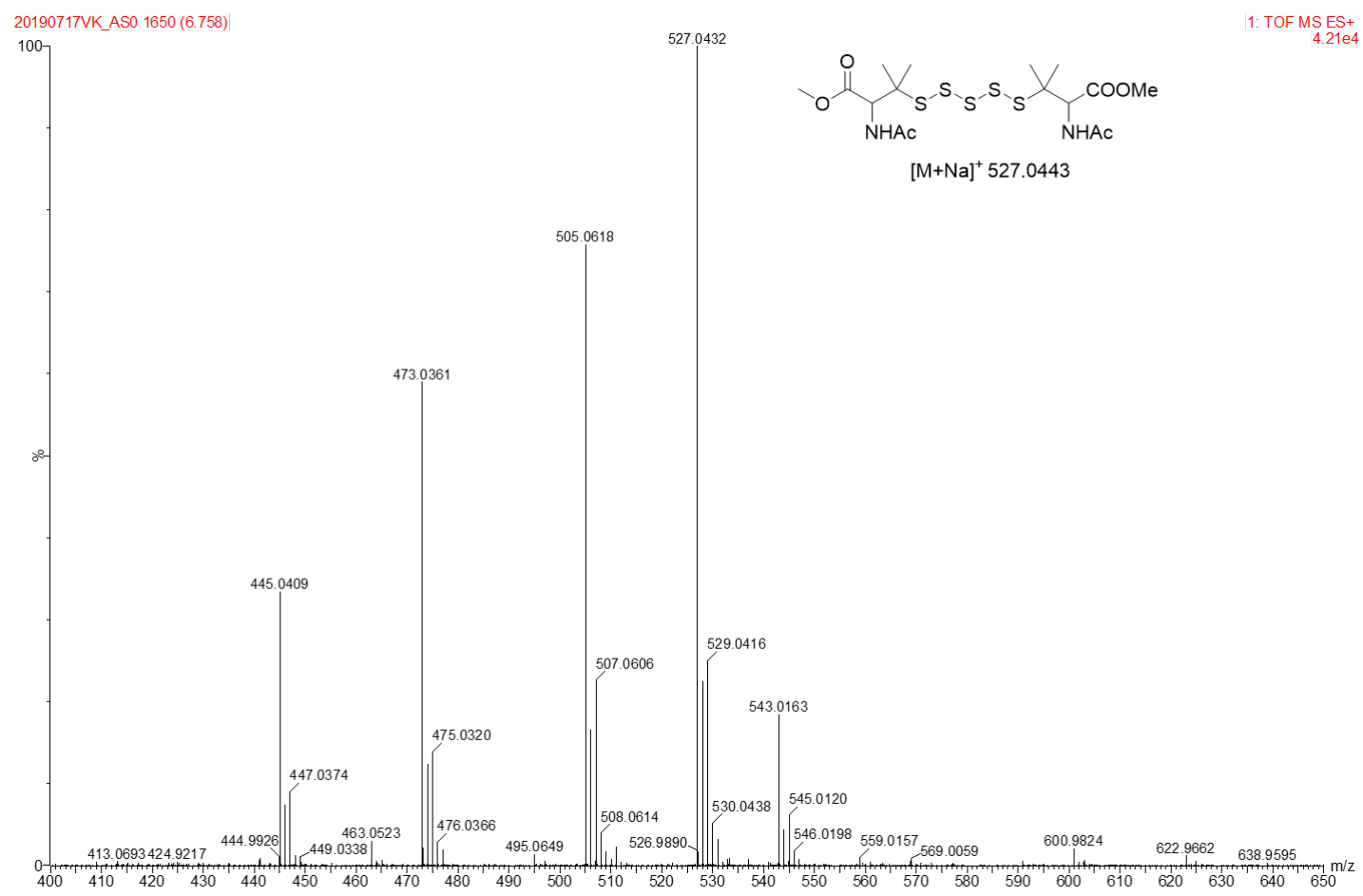

Figure S60. HRMS of the peak eluting at 6.76 min corresponding to symmetrical pentasulfide $\left(\mathrm{R}^{1} \mathrm{SS}_{3} \mathrm{SR}^{1}\right)$. 


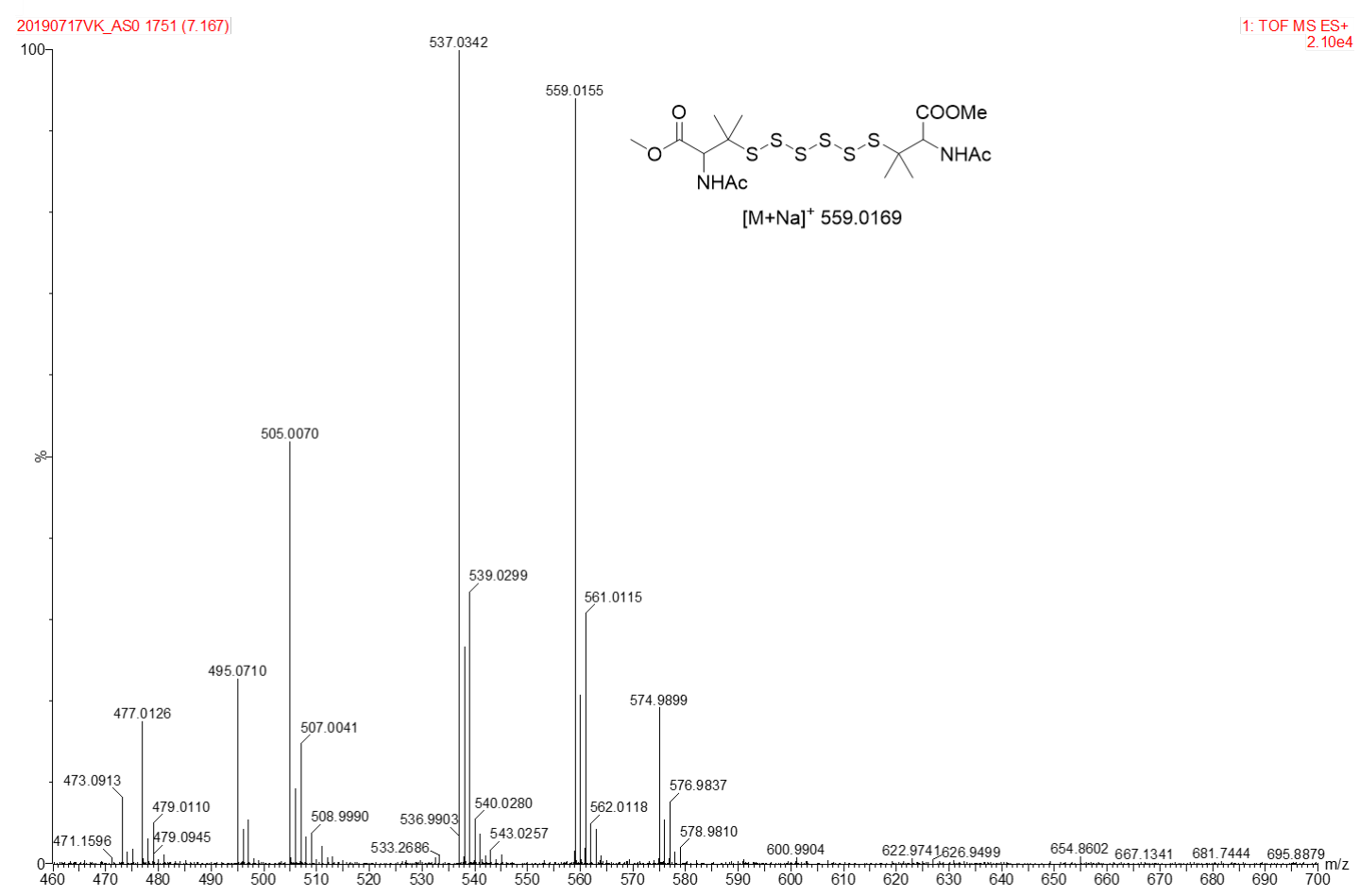

Figure S61. HRMS of the peak eluting at $7.17 \mathrm{~min}$ corresponding to symmetrical hexasulfide $\left(\mathrm{R}^{1} \mathrm{SS}_{4} \mathrm{SR}^{1}\right)$.

Decomposition of precursor $1 \mathrm{a}$ in the absence of trapping agent

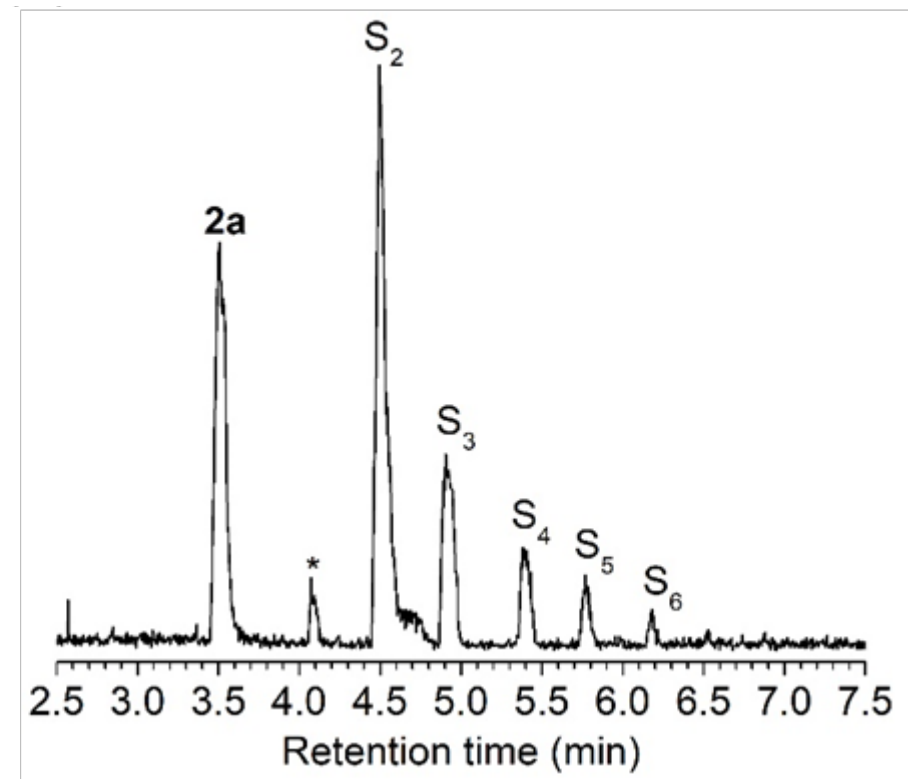

Figure S62. Decomposition of precursor 1a $(100 \mu \mathrm{M})$ in the absence of HPE-IAM incubated in pH 7.4 ammonium bicarbonate buffer $(50 \mathrm{mM})$ with DTPA $(100 \mu \mathrm{M})$ at $37^{\circ} \mathrm{C}$ for $10 \mathrm{~min}$. We do not observe evidence of an MS-observable RSSH peak, consistent with the relatively unstable nature of primary alkyl RSSH. 


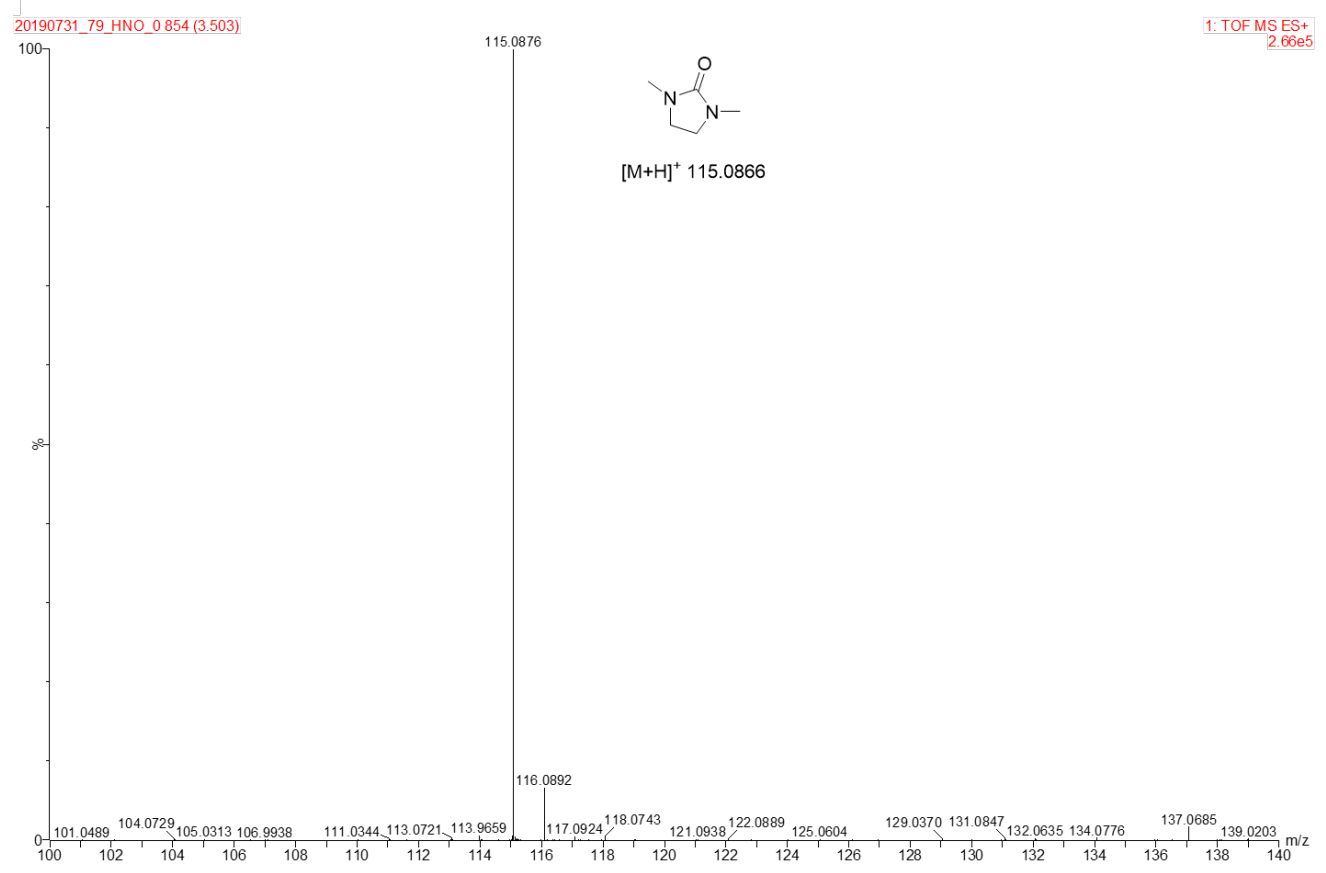

Figure S63. HRMS of the peak eluting at 3.50 min corresponding to byproduct 2a.

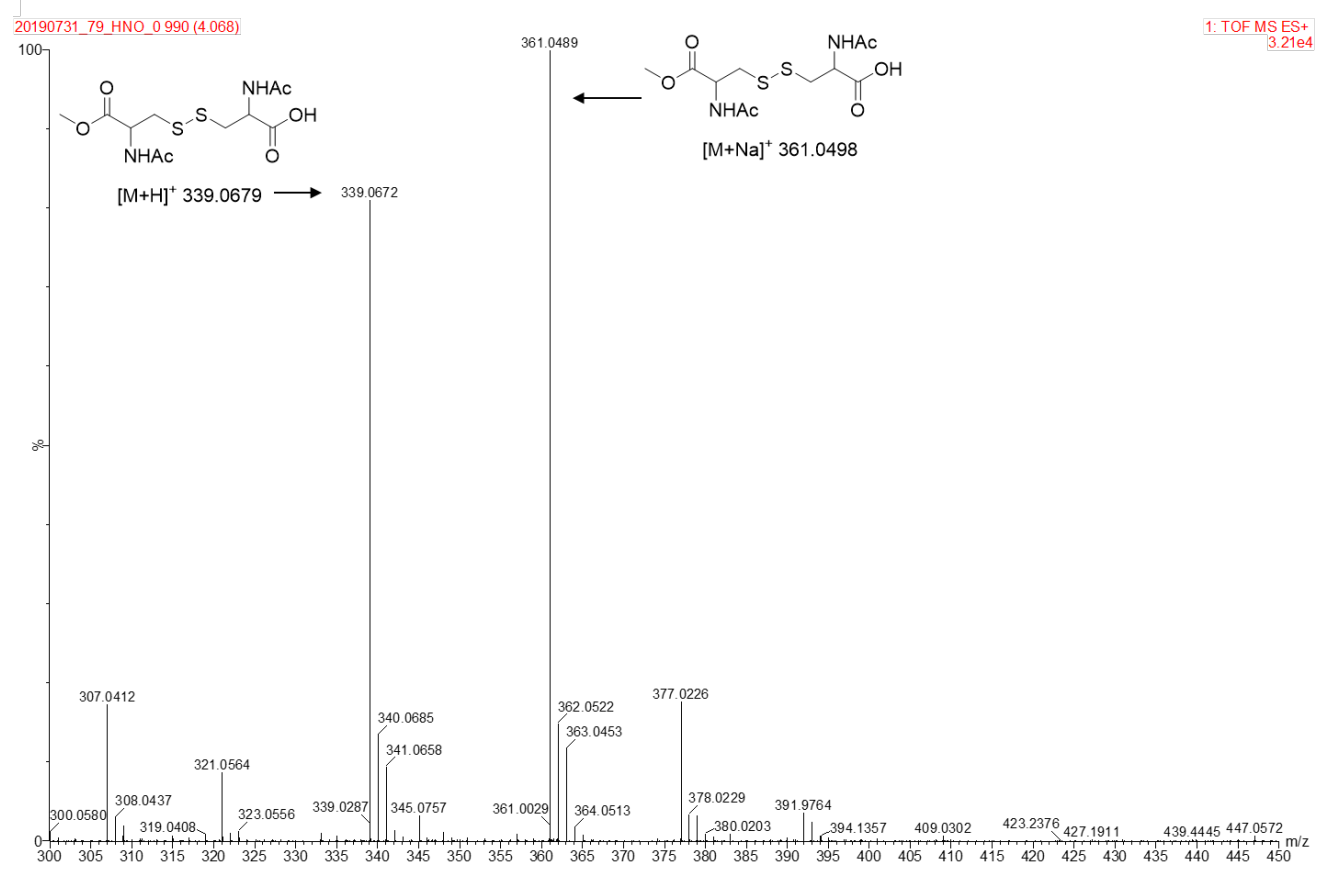

Figure S64. HRMS of the peak eluting at $4.07 \mathrm{~min}$ corresponding to $S$-((2-acetamido-3-methoxy-3oxopropyl)thio)- $N$-acetylcysteine. 


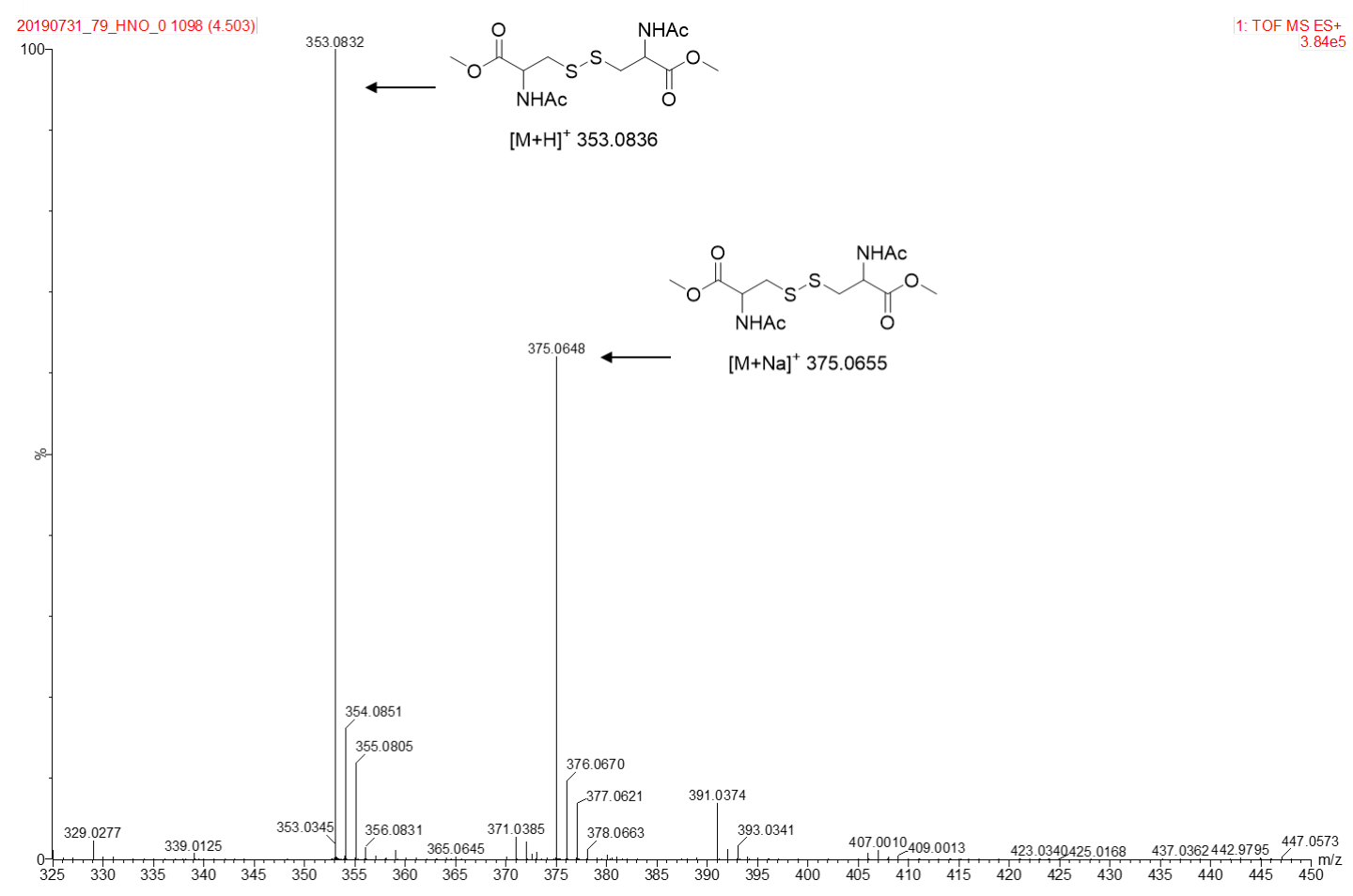

Figure S65. HRMS of the peak eluting at $4.50 \mathrm{~min}$ corresponding to $N$-acetyl- $O$-methyl-cystine (RSSR).

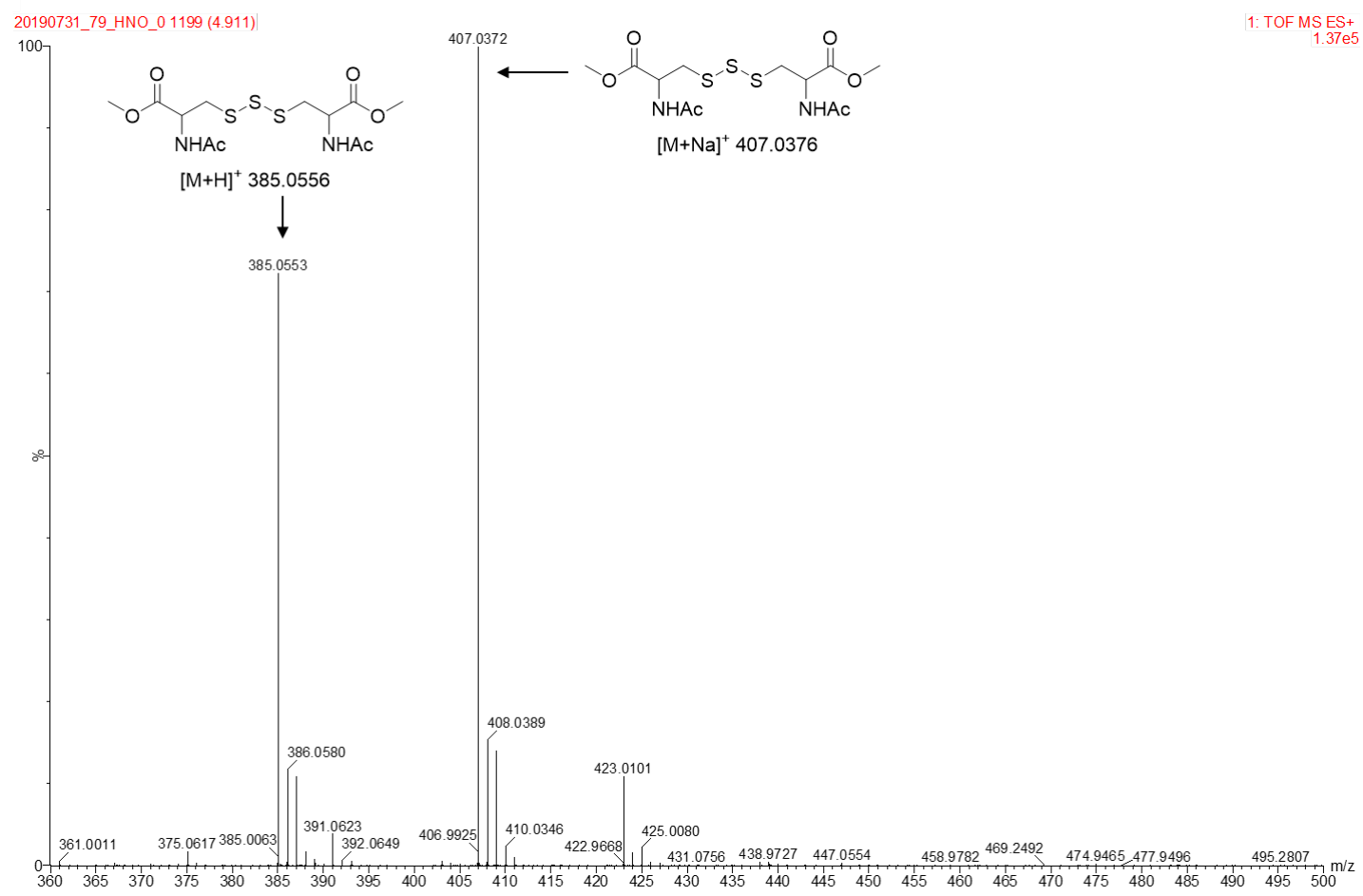

Figure S66. HRMS of the peak eluting at 4.91 min corresponding to trisulfide (RSSSR). 


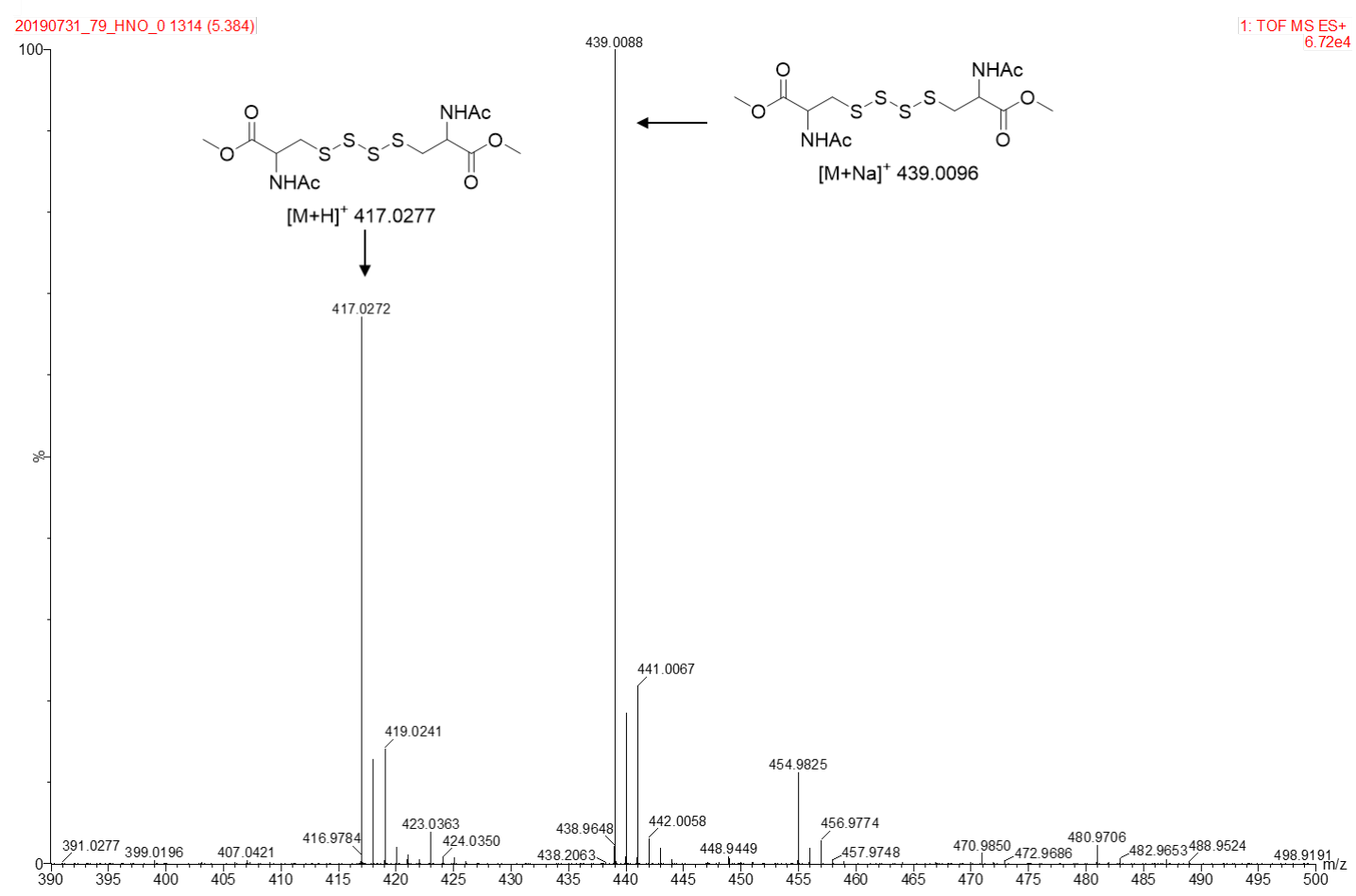

Figure S67. HRMS of the peak eluting at 5.38 min corresponding to tetrasulfide ( $\mathrm{RSS}_{2} \mathrm{SR}$ ).

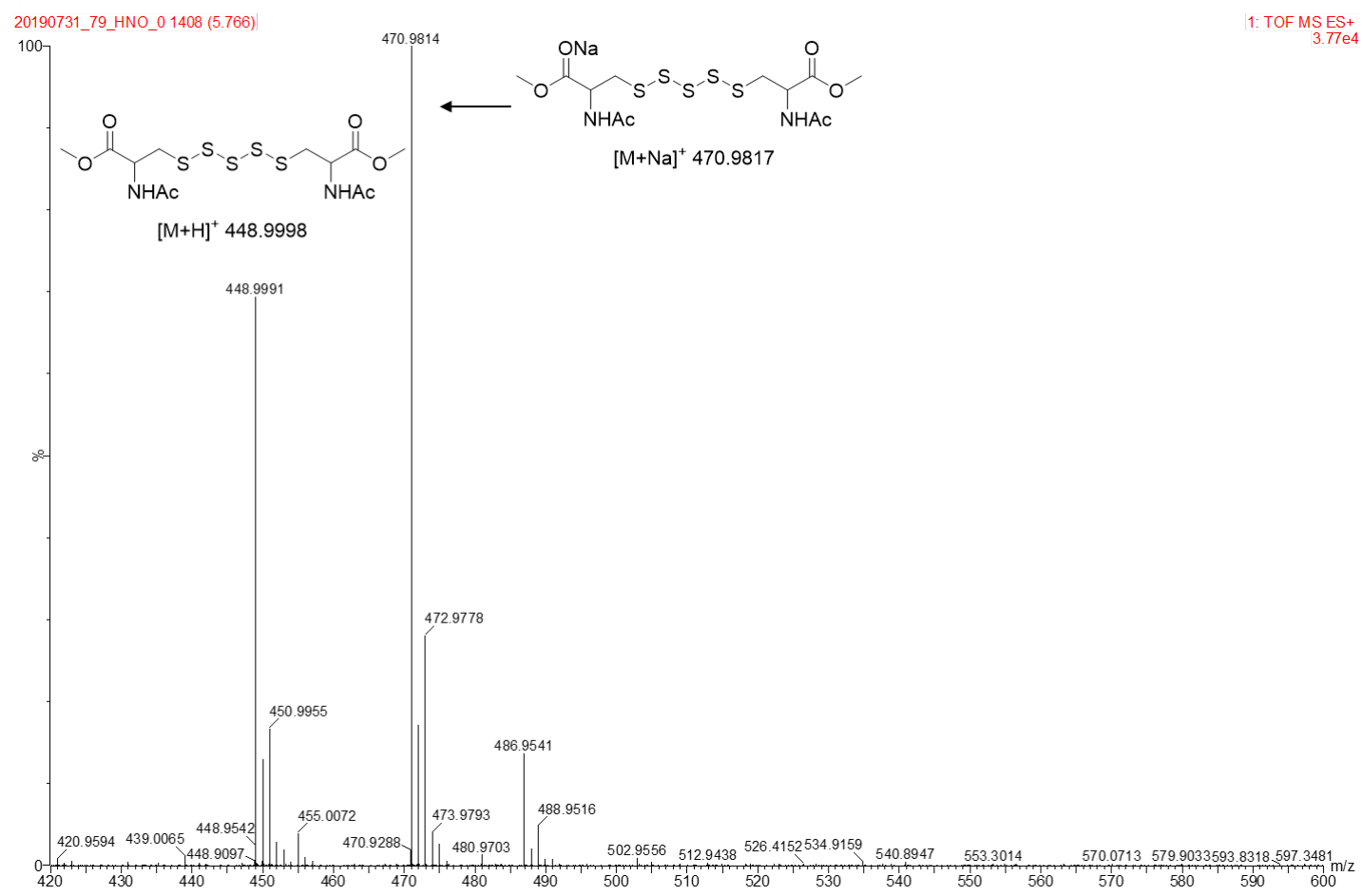

Figure S68. HRMS of the peak eluting at 5.77 min corresponding to pentasulfide $\left(\mathrm{RSS}_{3} \mathrm{SR}\right)$. 


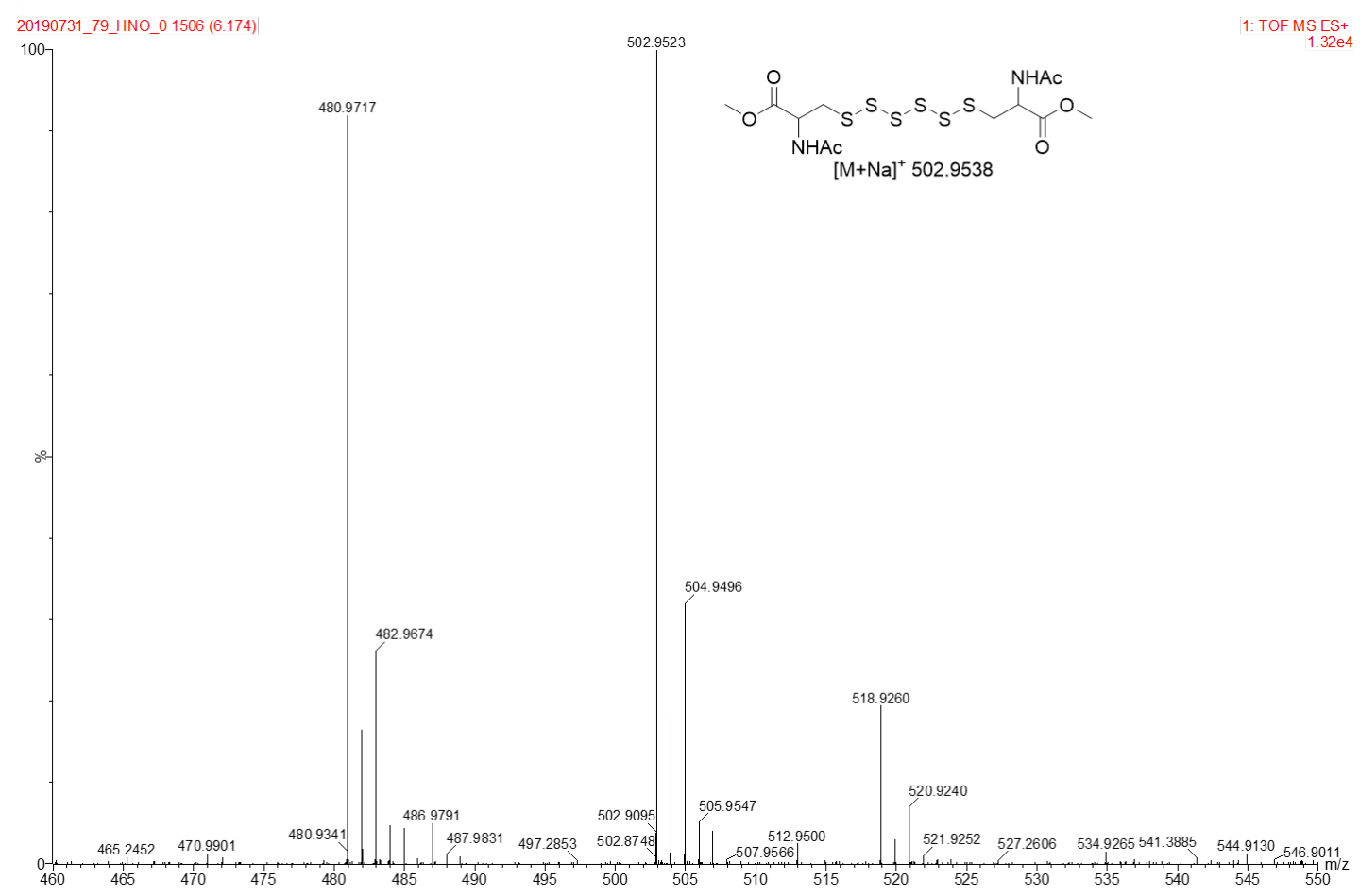

Figure S69. HRMS of the peak eluting at 6.17 min corresponding to hexasulfide ( $\left.\mathrm{RSS}_{4} \mathrm{SR}\right)$.

\section{RSSH generation from the precursor $7 \mathrm{~b}$ in the presence of NAC}

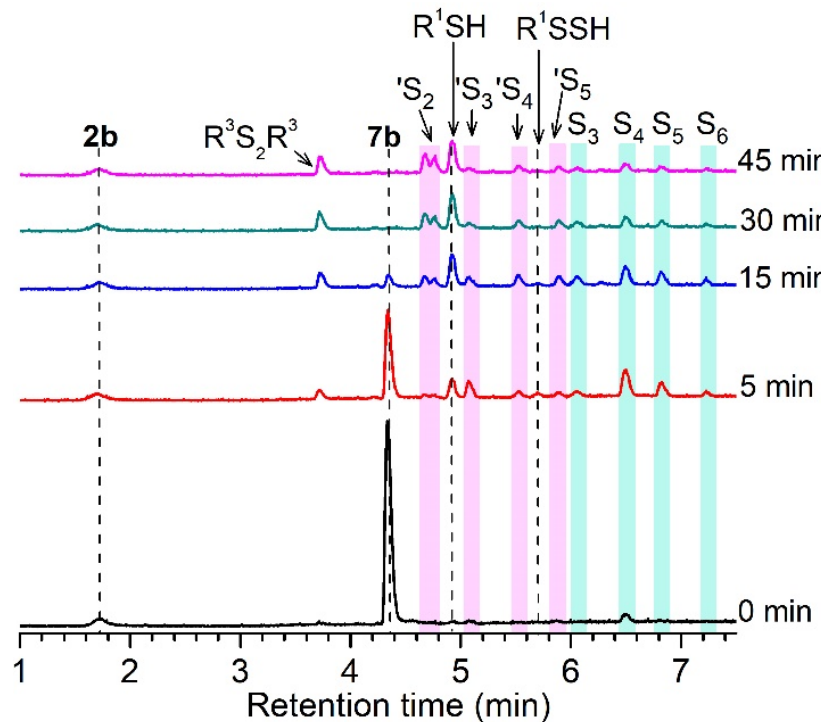

Figure S70. UPLC-MS chromatograms of RSSH generation from $7 \mathbf{b}(100 \mu \mathrm{M})$ in the presence of NAC $(500 \mu \mathrm{M})$ incubated in $\mathrm{pH} 7.4$ ammonium bicarbonate $(50 \mathrm{mM})$ with DTPA $(100 \mu \mathrm{M})$ at $37{ }^{\circ} \mathrm{C}$. Aliquots taken at various times were quenched with $1 \%$ formic acid and analyzed by UPLC-MS. A peak at 5.67 min attributed to RSSH is observed under these conditions. RSSH-derived symmetrical dialkyl disulfides labeled as $\mathrm{S}_{3}$ to $\mathrm{S}_{6}\left(\mathrm{R}^{1} \mathrm{SS}_{\mathrm{n}} \mathrm{SR}^{1}, \mathrm{n}=1-4\right.$, cyan highlight), and unsymmetrical dialkyl disulfides labeled as ' $\mathrm{S}_{2}$ to ' $\mathrm{S}_{5}\left(\mathrm{R}^{3} \mathrm{SS}_{\mathrm{n}} \mathrm{SR}^{1}, \mathrm{n}=0-3\right.$, pink highlight $)$ were observed. 


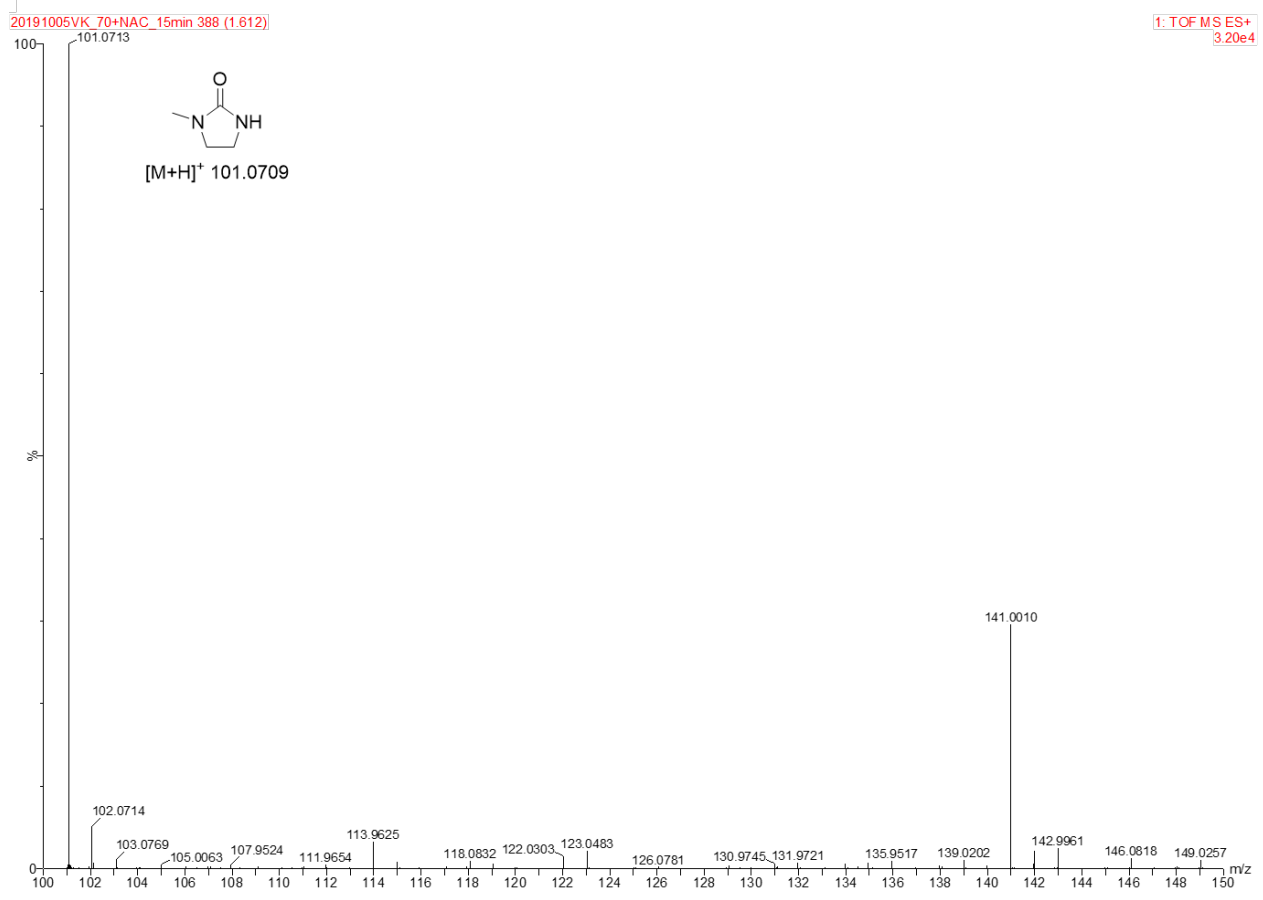

Figure S71. HRMS of the peak eluting at 1.61 min corresponding to byproduct $\mathbf{2 b}$.

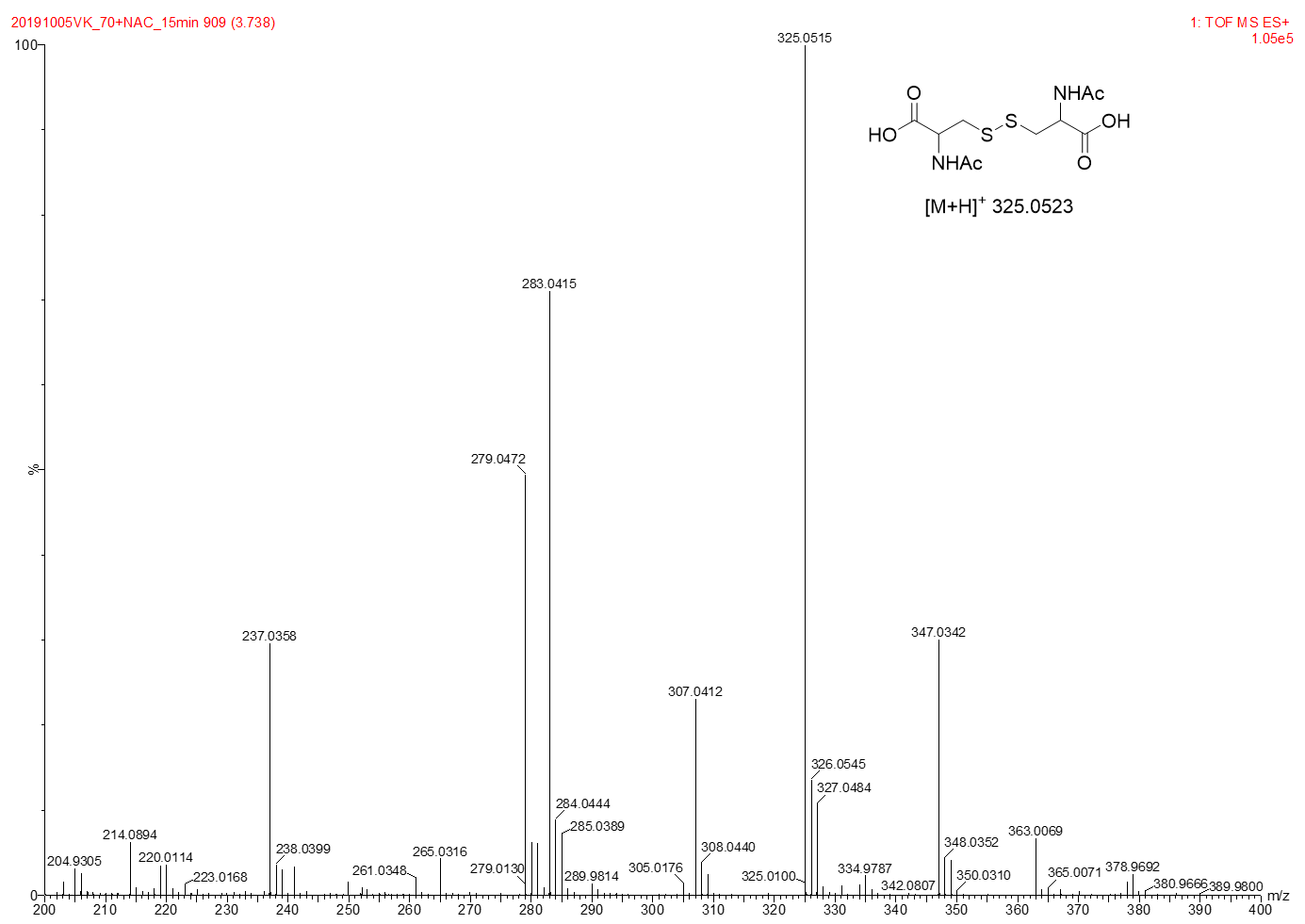

Figure S72. HRMS of the peak eluting at 3.73 min corresponding to $N$-acetyl cystine. 


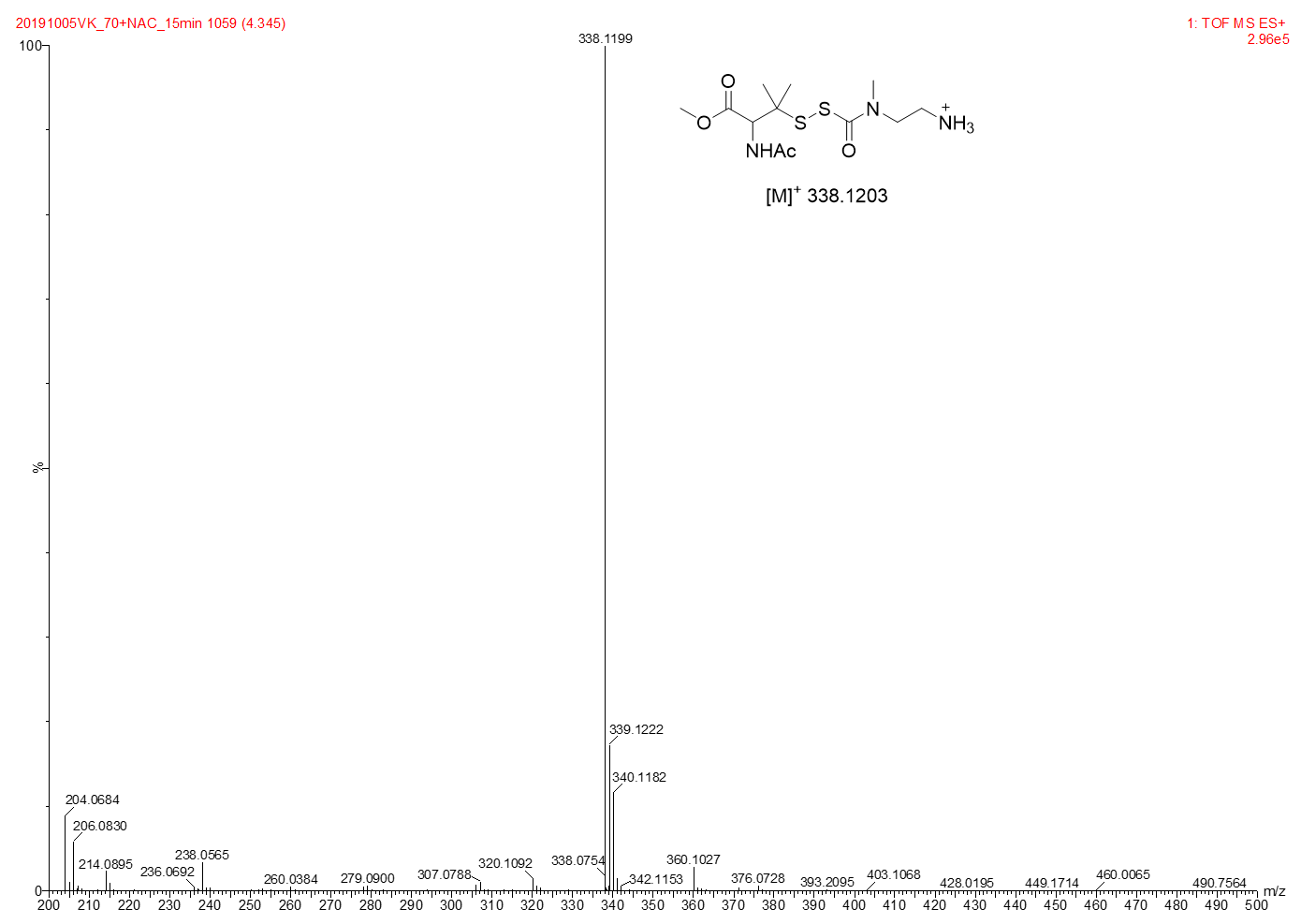

Figure S73. HRMS of the peak eluting at 4.34 min corresponding to precursor $7 \mathbf{b}$.

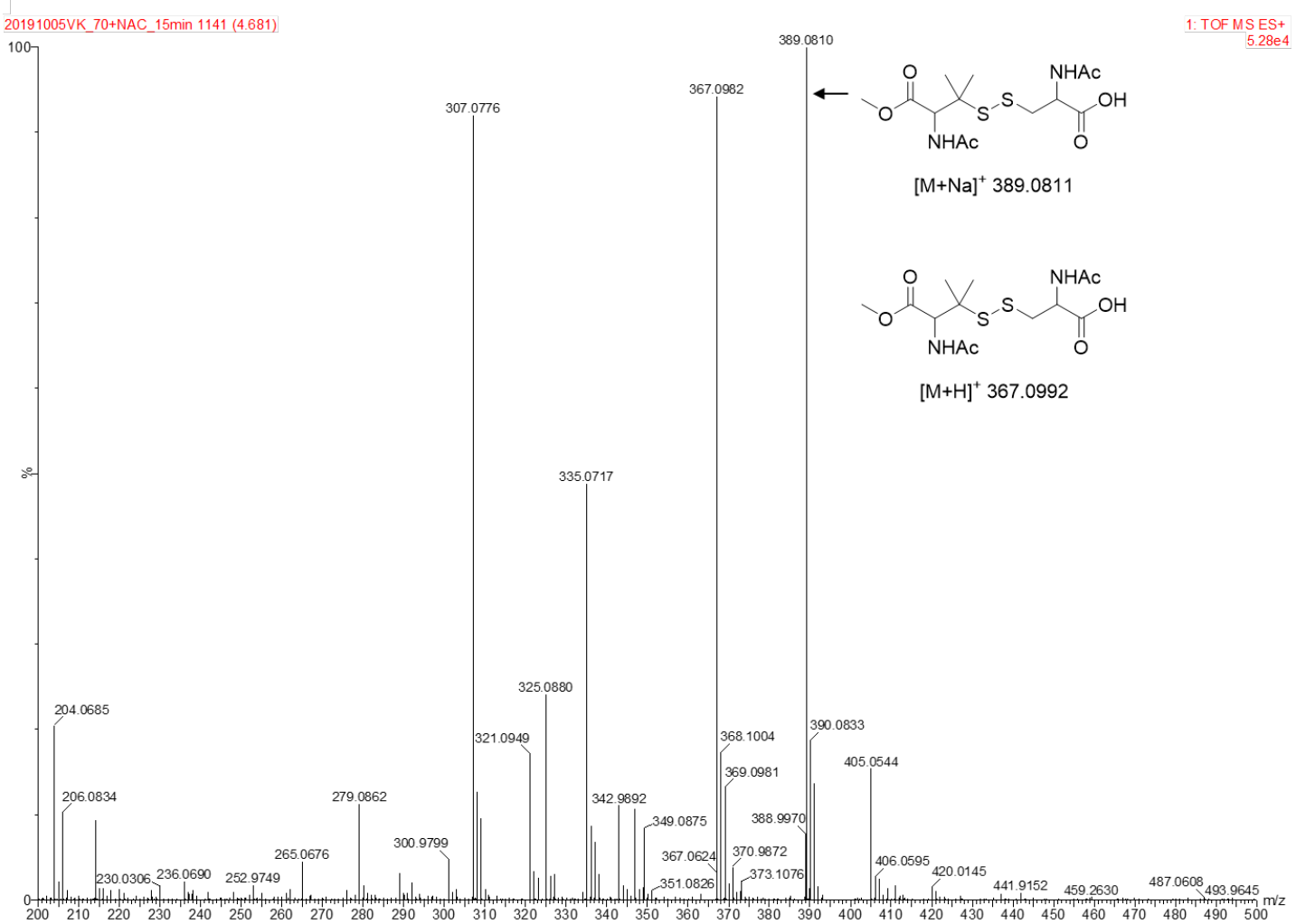

Figure S74. HRMS of the peak eluting at 4.68 min corresponding to unsymmetrical disulfide $\left(\mathrm{R}^{1} \mathrm{SSR}^{3}\right)$. 


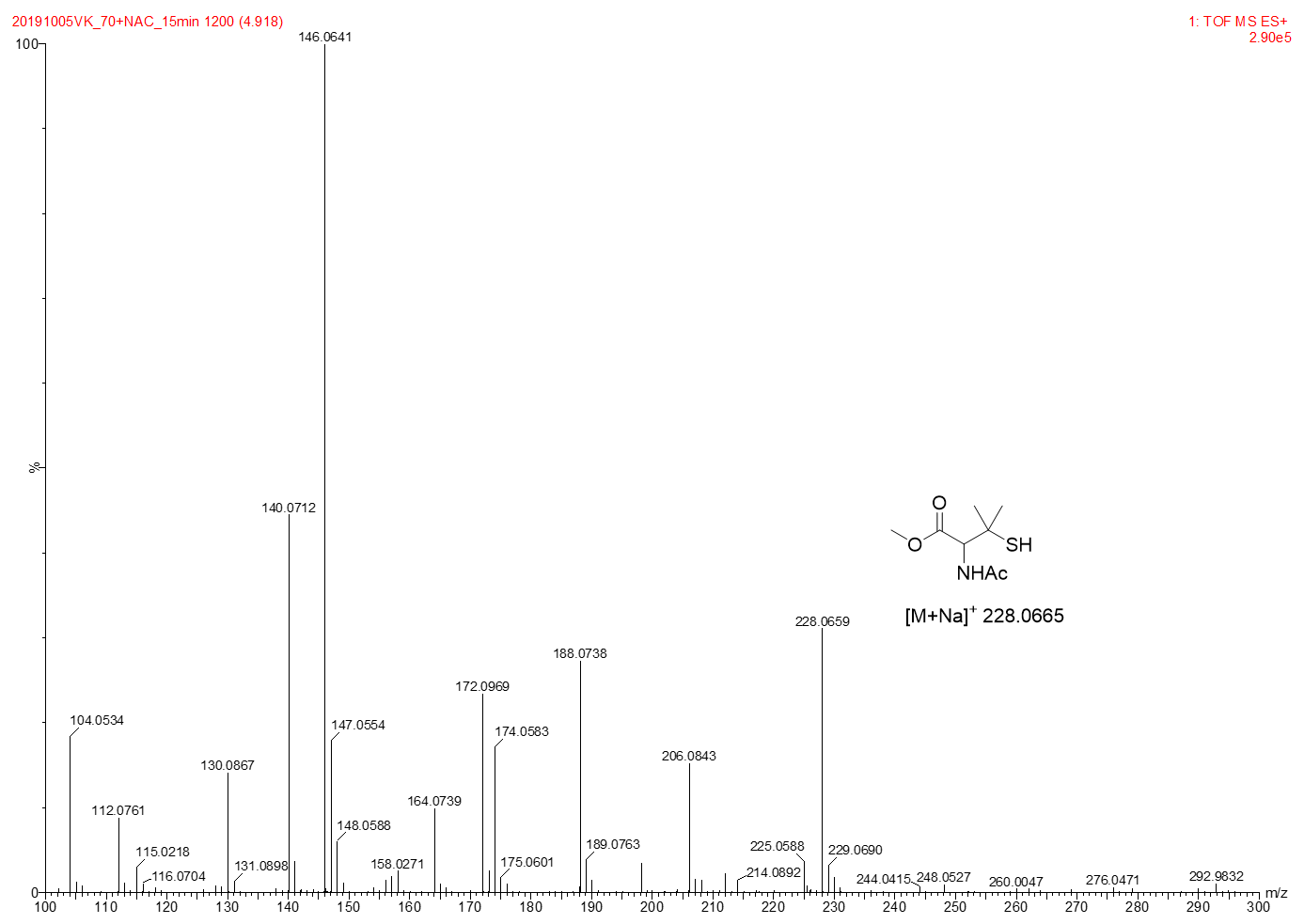

Figure S75. HRMS of the peak eluting at 4.92 min corresponding to $N$-acetyl-penicillamine methyl ester.

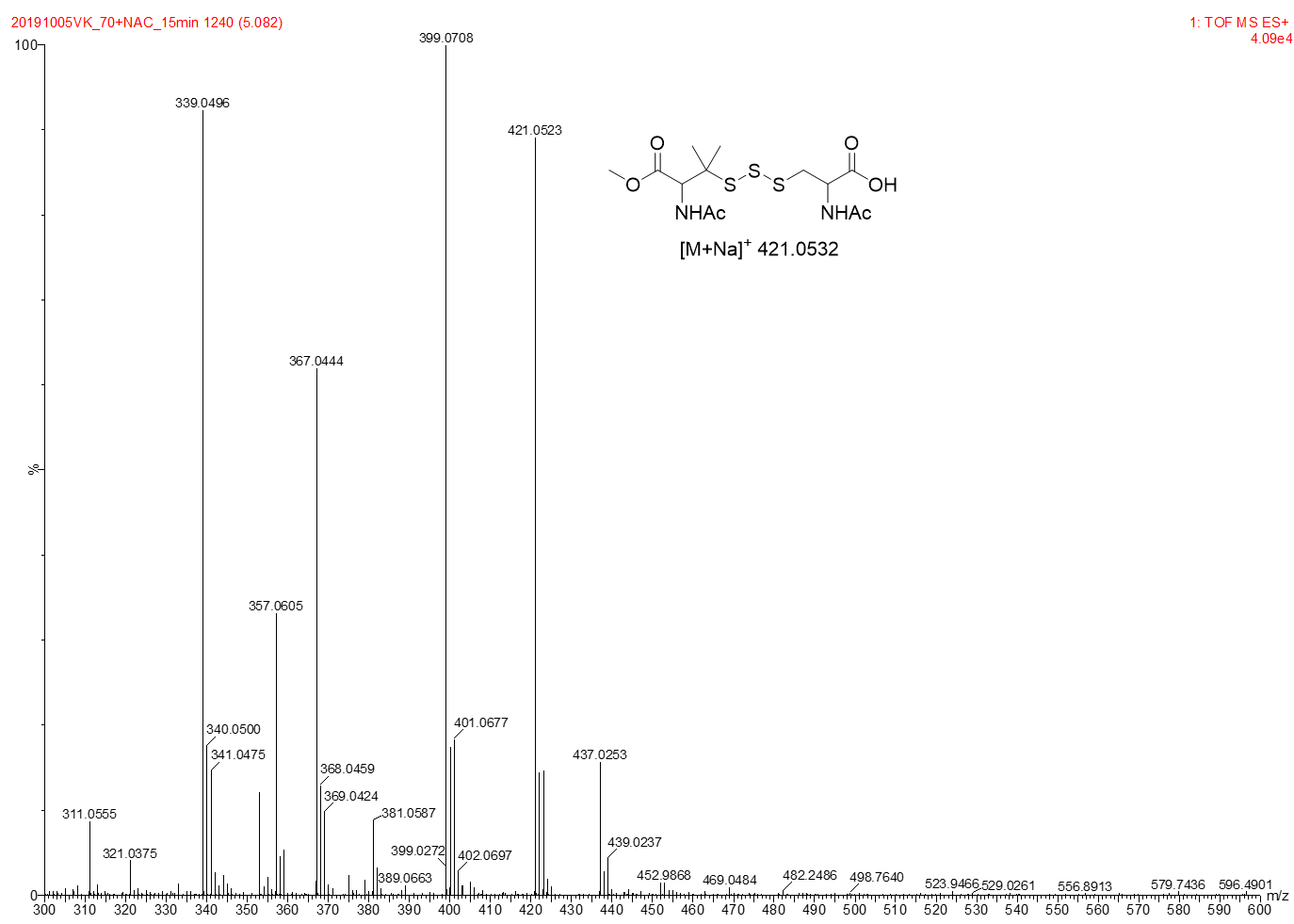

Figure S76. HRMS of the peak eluting at 5.08 min corresponding to unsymmetrical trisulfide $\left(\mathrm{R}^{1} \mathrm{SSSR}^{3}\right)$. 


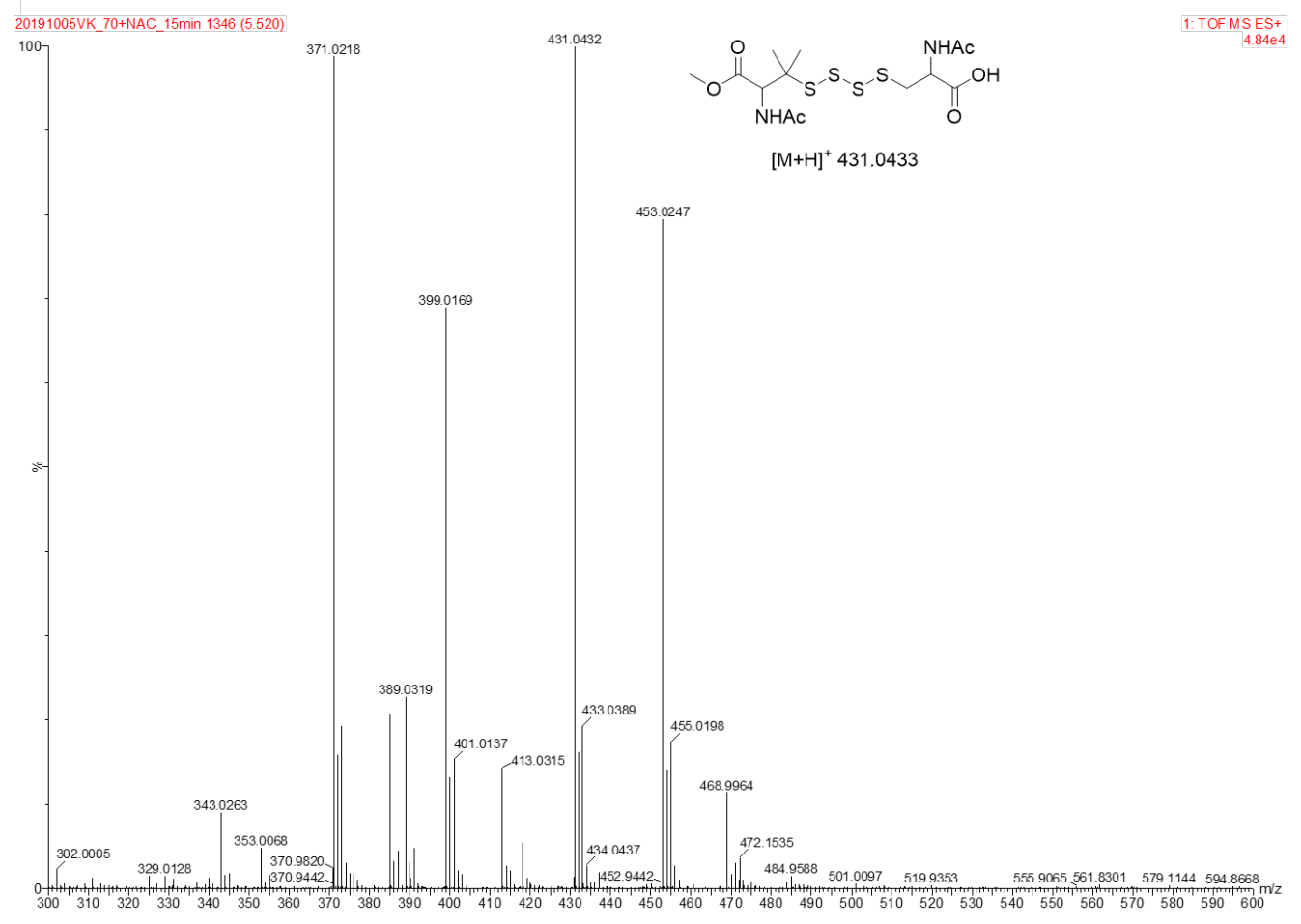

Figure S77. HRMS of the peak eluting at $5.52 \mathrm{~min}$ corresponding to unsymmetrical tetrasulfide $\left(\mathrm{R}^{1} \mathrm{SS}_{2} \mathrm{SR}^{3}\right)$.

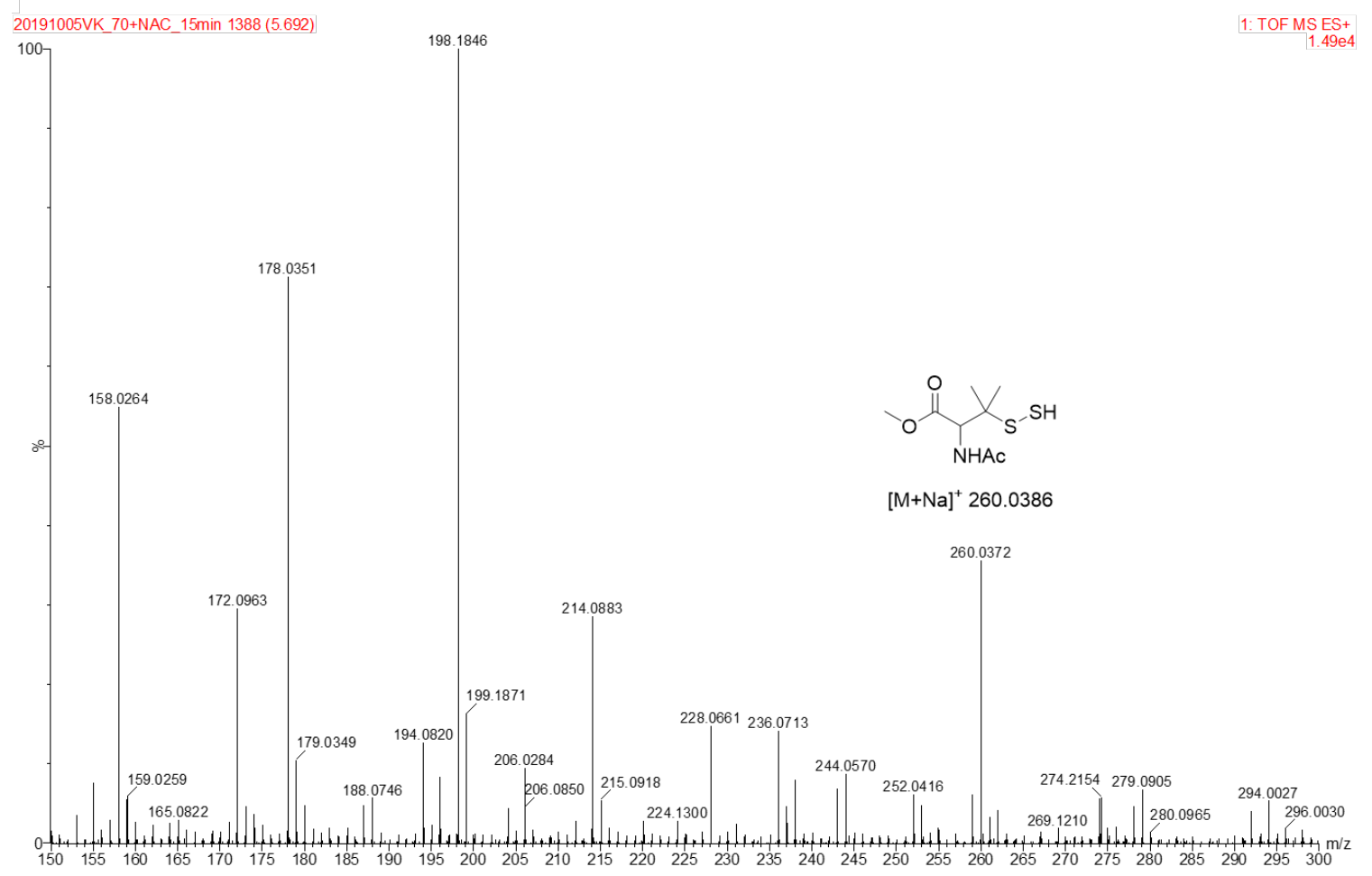

Figure S78. HRMS of the peak eluting at 5.67 min corresponding to ${ }^{1} \mathrm{SSH}$. 


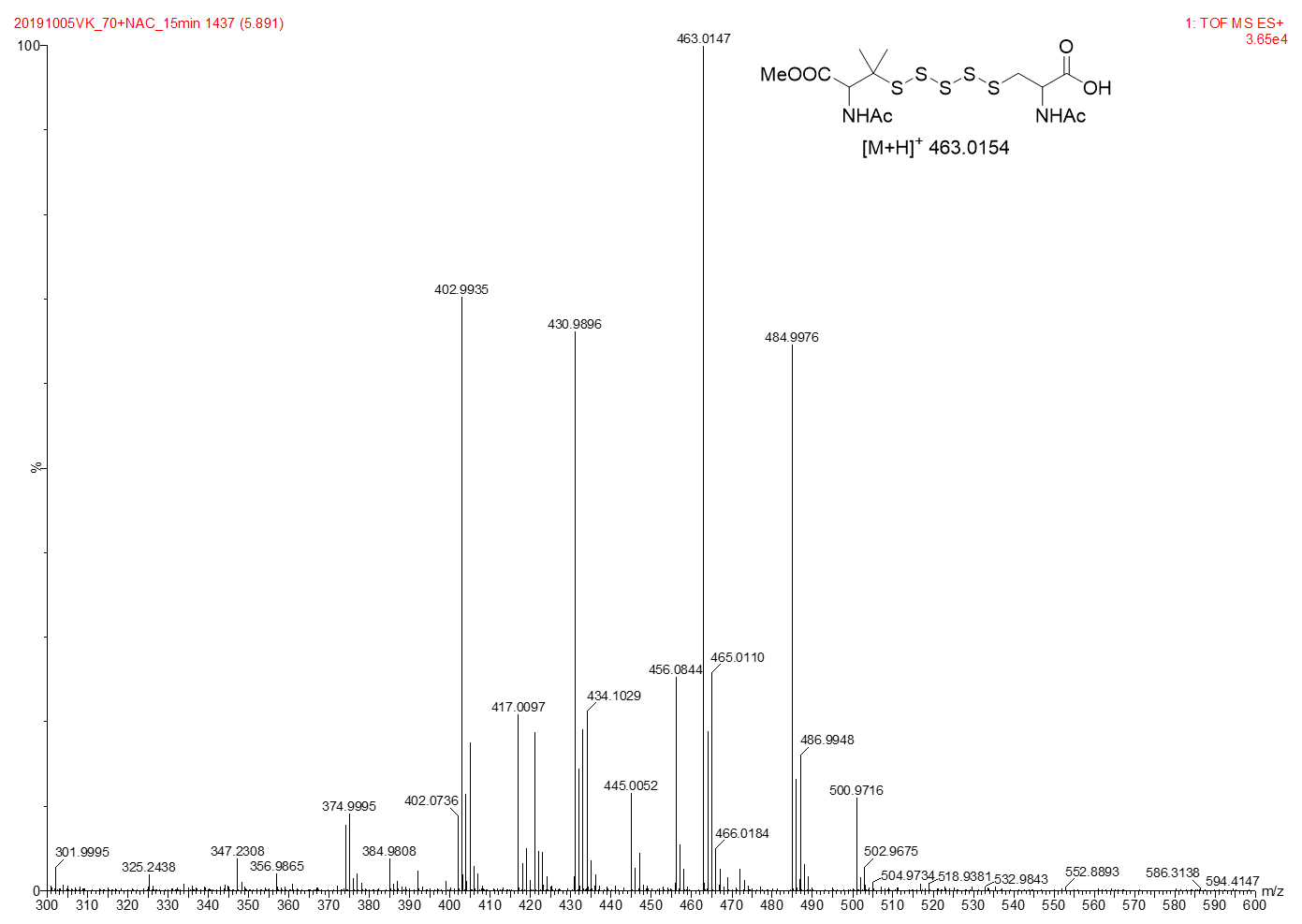

Figure S79. HRMS of the peak eluting at $5.89 \mathrm{~min}$ corresponding to unsymmetrical pentasulfide $\left(\mathrm{R}^{1} \mathrm{SS}_{3} \mathrm{SR}^{3}\right)$.

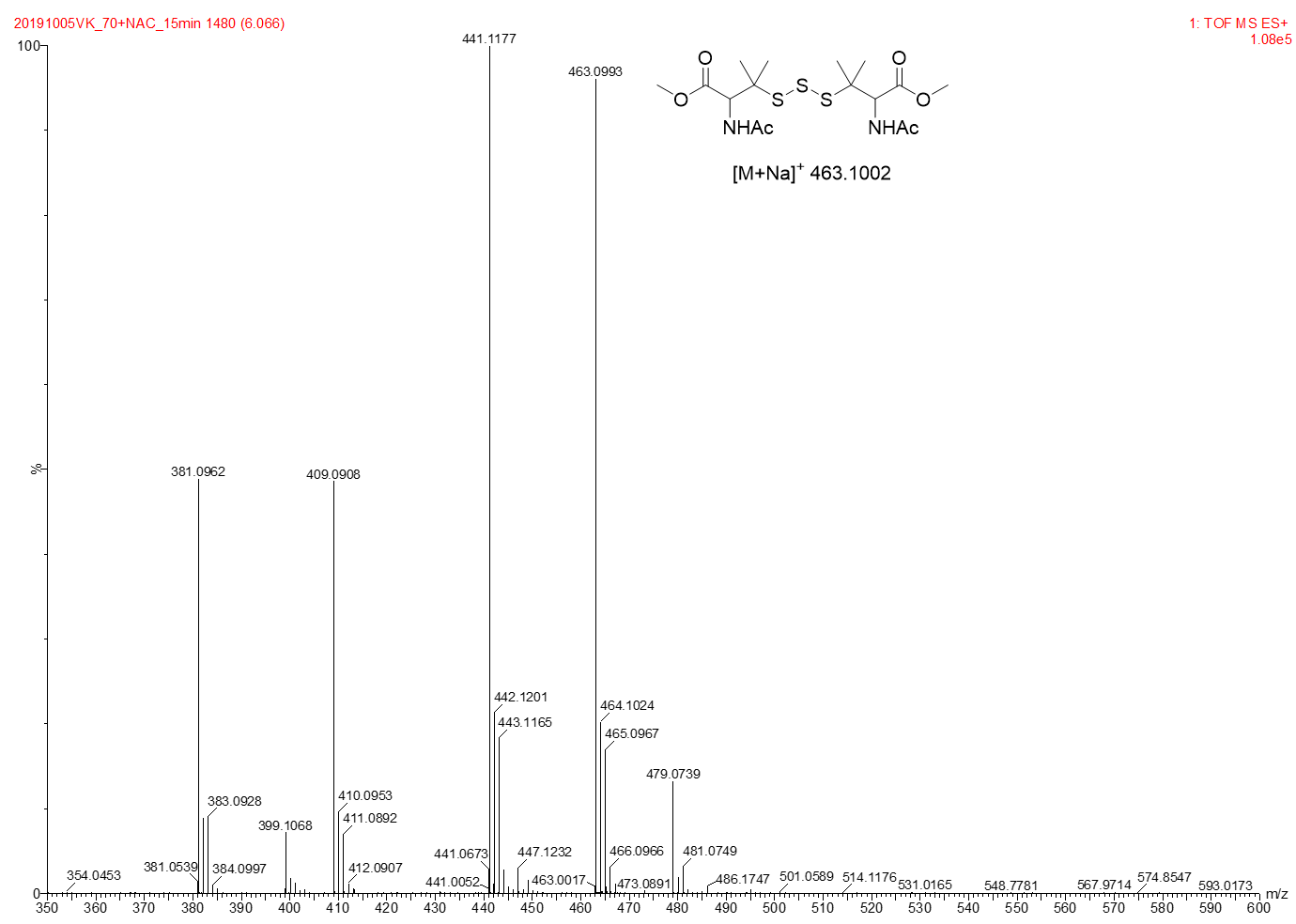

Figure S80. HRMS of the peak eluting at 6.02 min corresponding to symmetrical trisulfide $\left(\mathrm{R}^{1} \mathrm{SSSR}^{1}\right)$. 


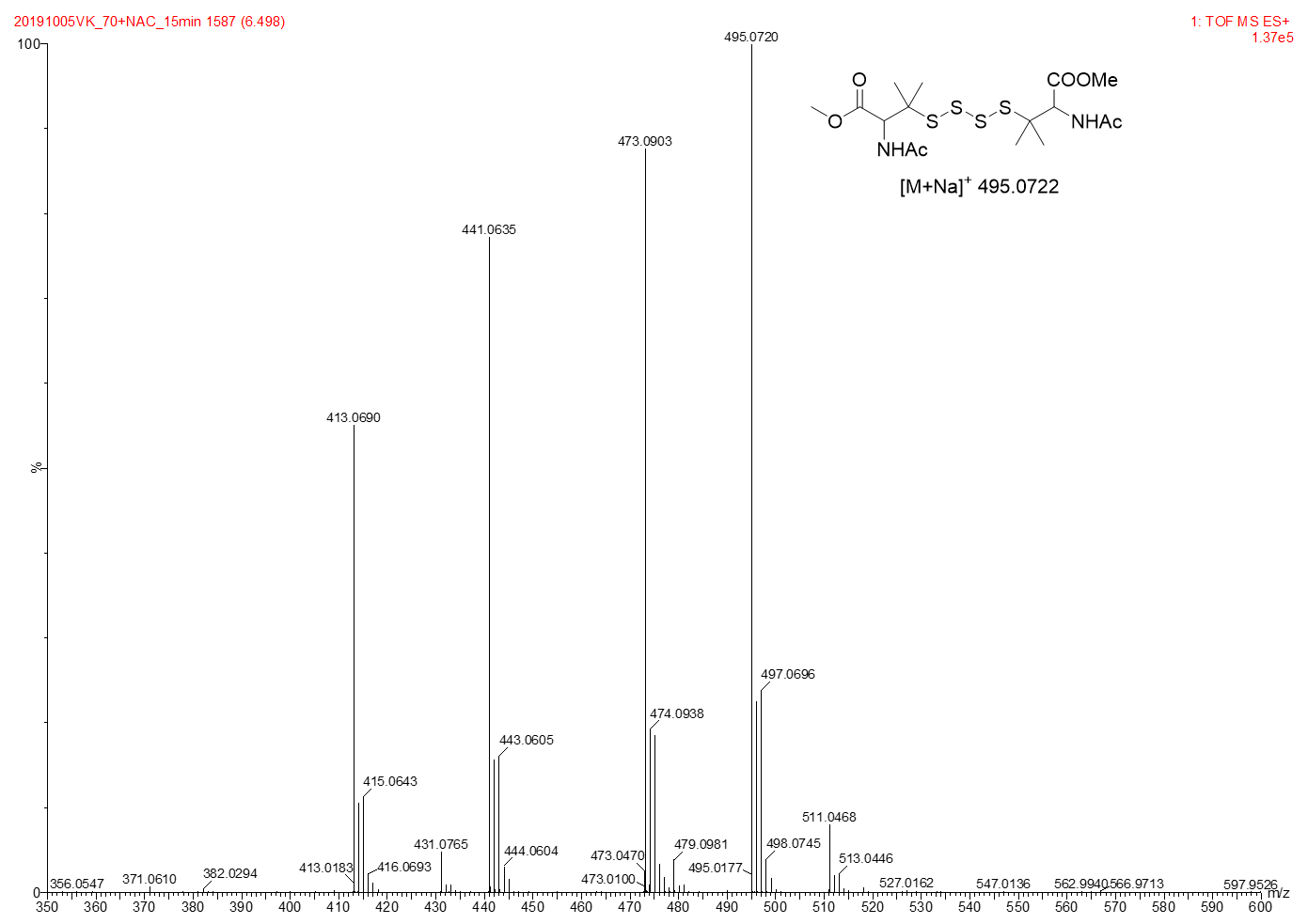

Figure S81. HRMS of the peak eluting at $6.50 \mathrm{~min}$ corresponding to symmetrical tetrasulfide $\left(\mathrm{R}^{1} \mathrm{SS}_{2} \mathrm{SR}^{1}\right)$.

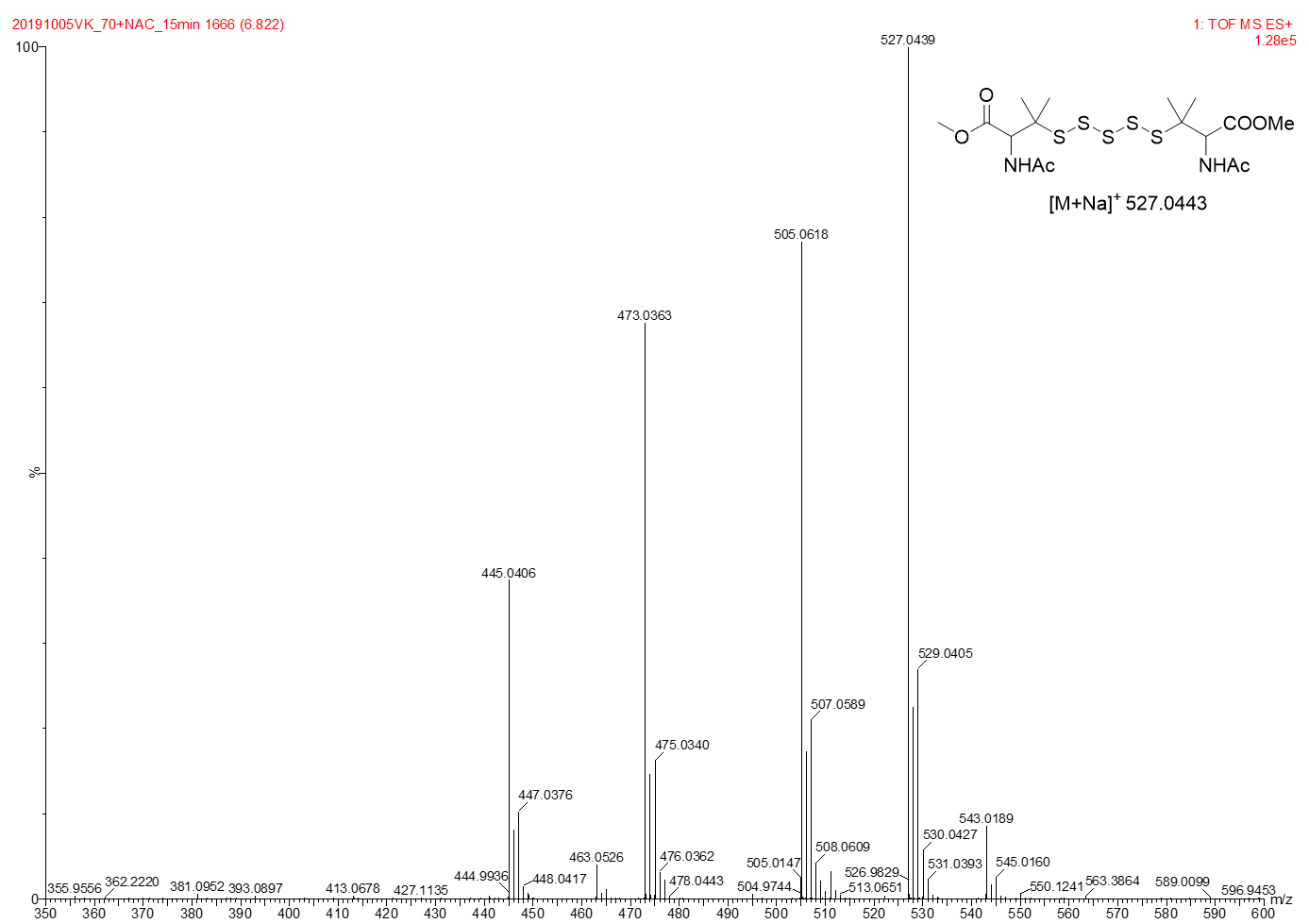

Figure S82. HRMS of the peak eluting at $6.82 \mathrm{~min}$ corresponding to symmetrical pentasulfide $\left(\mathrm{R}^{1} \mathrm{SS}_{3} \mathrm{SR}^{1}\right)$. 


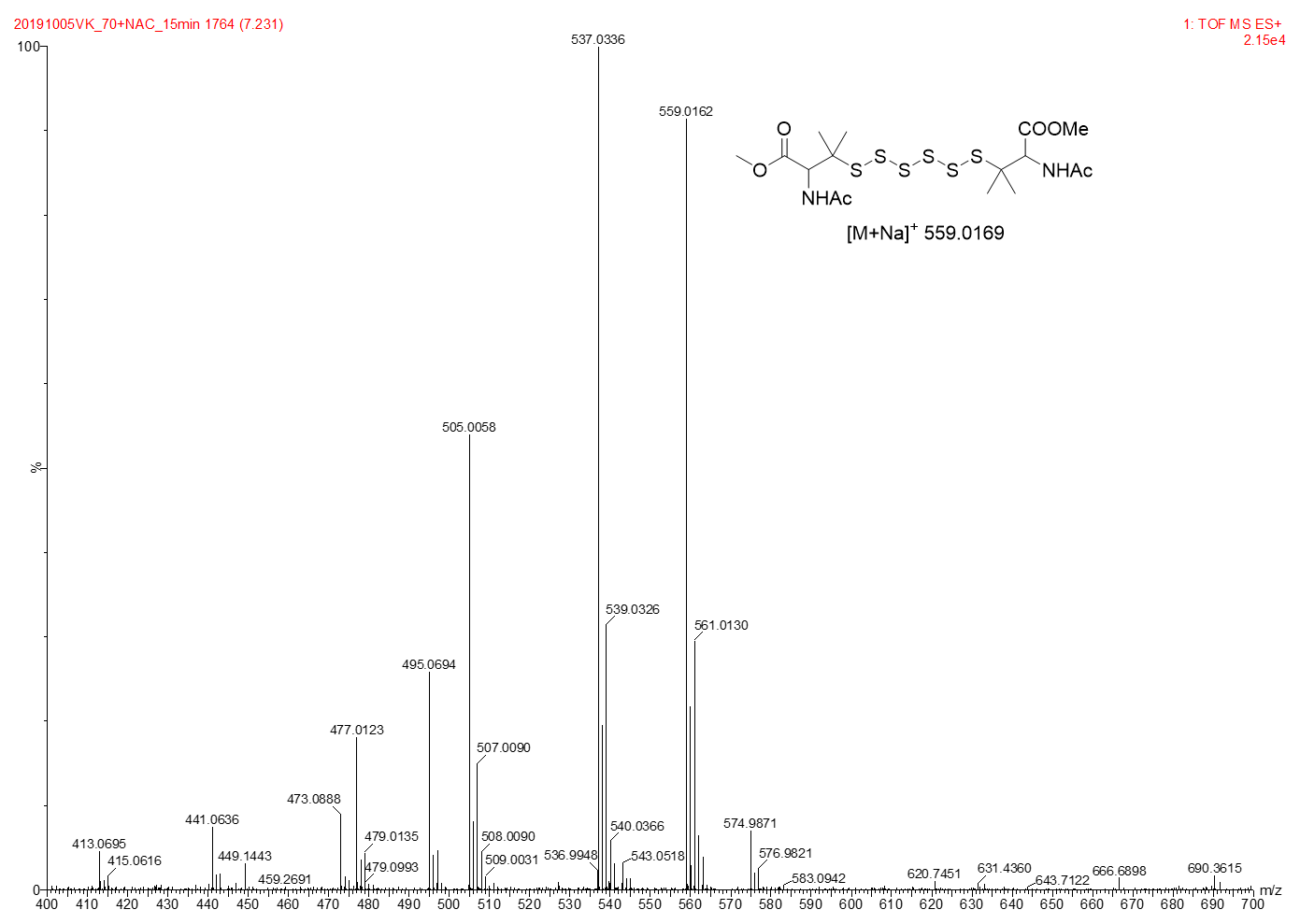

Figure S83. HRMS of the peak eluting at $7.23 \mathrm{~min}$ corresponding to symmetrical hexasulfide $\left(\mathrm{R}^{1} \mathrm{SS}_{4} \mathrm{SR}^{1}\right)$.

RSSH generation from the precursor $7 \mathrm{c}$ in the presence of NAC

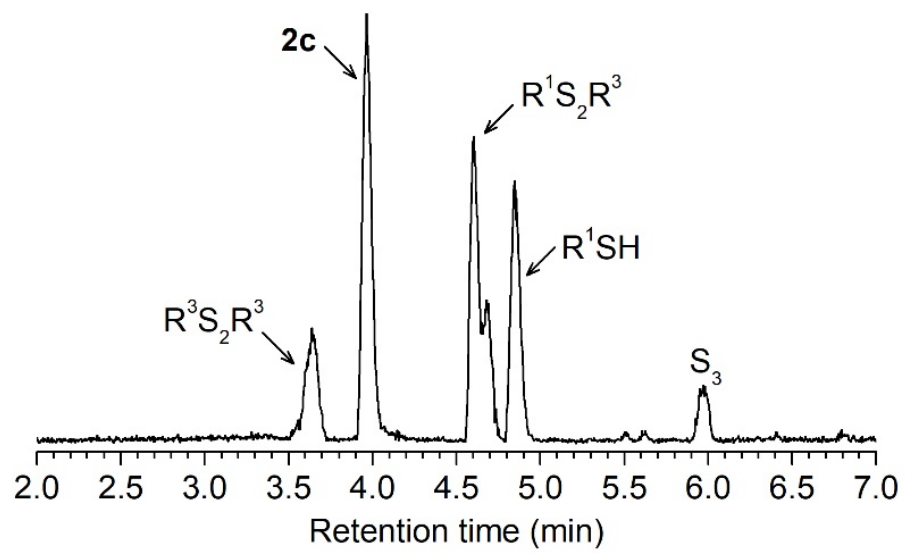

Figure S84. UPLC-MS chromatograms of RSSH generation from 7c $(100 \mu \mathrm{M})$ in the presence of NAC $(500 \mu \mathrm{M})$ incubated in $\mathrm{pH} 7.4$ ammonium bicarbonate $(50 \mathrm{mM})$ with DTPA $(100 \mu \mathrm{M})$ at $37{ }^{\circ} \mathrm{C}$ for $60 \mathrm{~min}$. An aliquot $(200 \mu \mathrm{L})$ was taken, quenched with $1 \%$ formic acid $(200 \mu \mathrm{L})$ and analyzed by UPLC-MS. A peak at 3.64 min attributed to $N$-acetyl cystine $\left(\mathrm{R}^{3} \mathrm{~S}_{2} \mathrm{R}^{3}\right)$, formed by NAC reaction with unsymmetrical disulfide $\left(\mathrm{R}^{1} \mathrm{~S}_{2} \mathrm{R}^{3}\right)$, is observed under these conditions. A minor amount of RSSH-derived dialkyl trisulfides $\left(\mathrm{S}_{3}\right)$ is also observed, indicating that RSSH release from 7c under these conditions. 


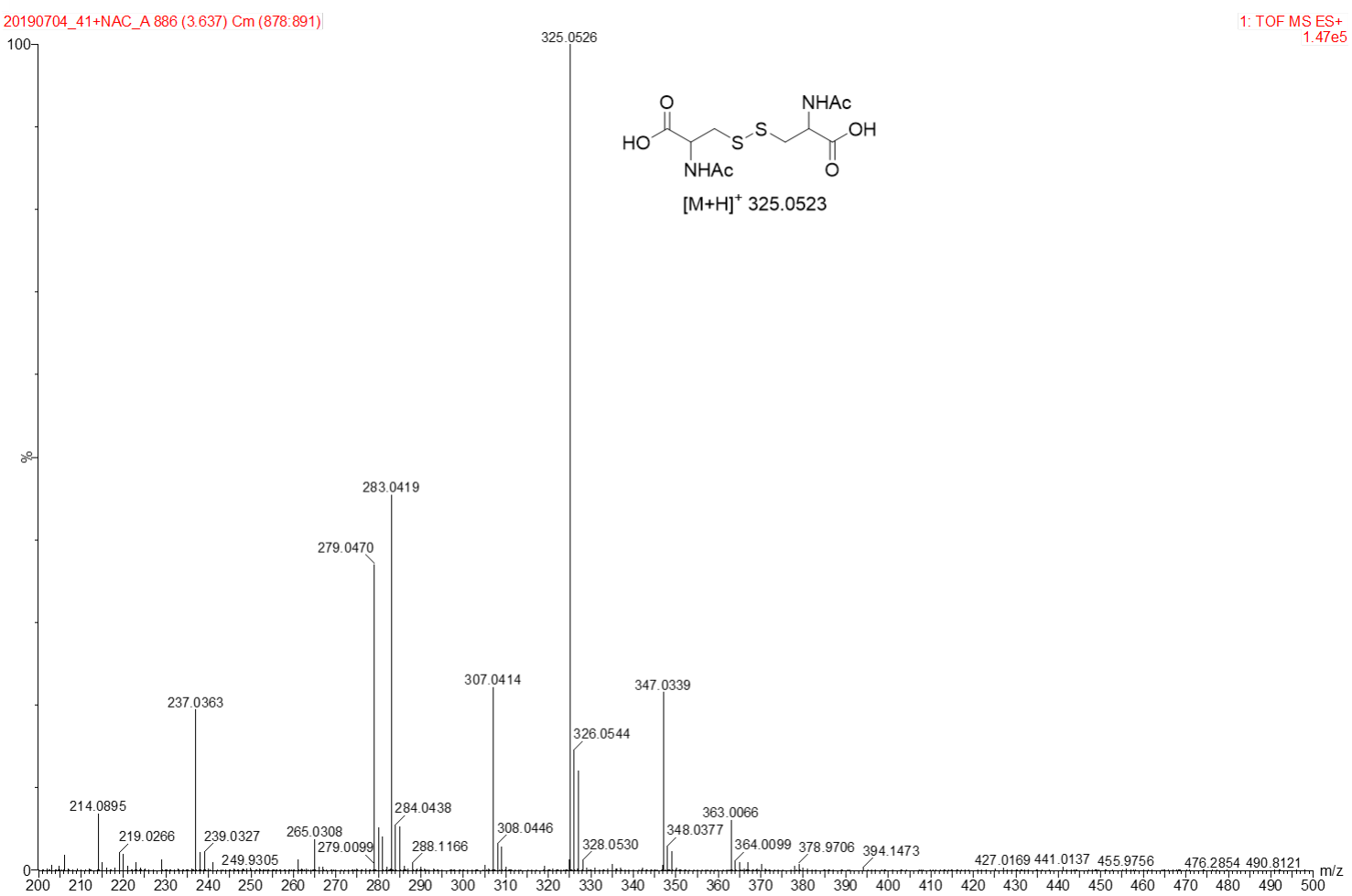

Figure S85. HRMS of the peak eluting at 3.64 min corresponding to $N$-acetyl cystine.

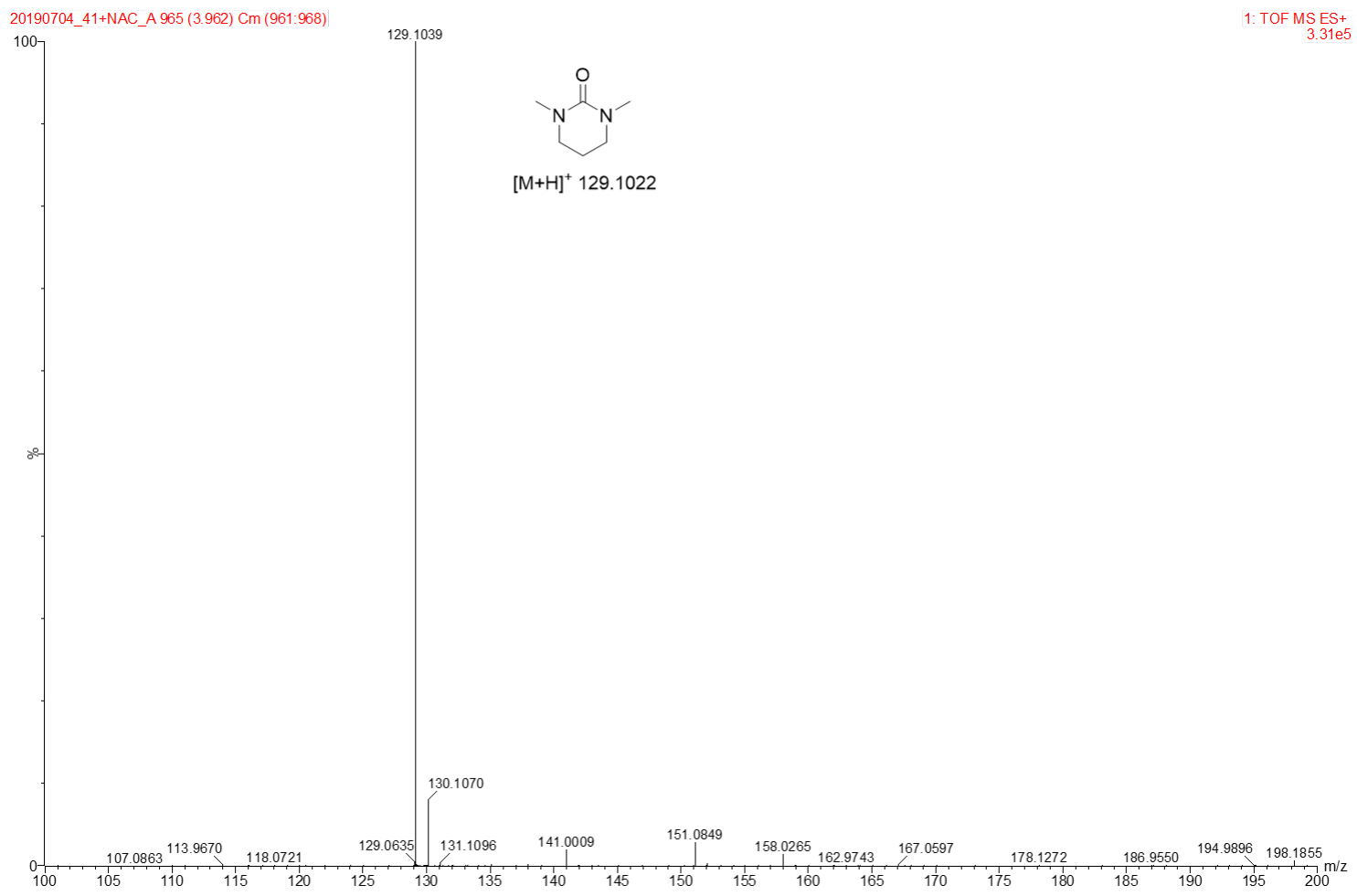

Figure S86. HRMS of the peak eluting at 3.96 min corresponding to byproduct $\mathbf{2 c}$. 


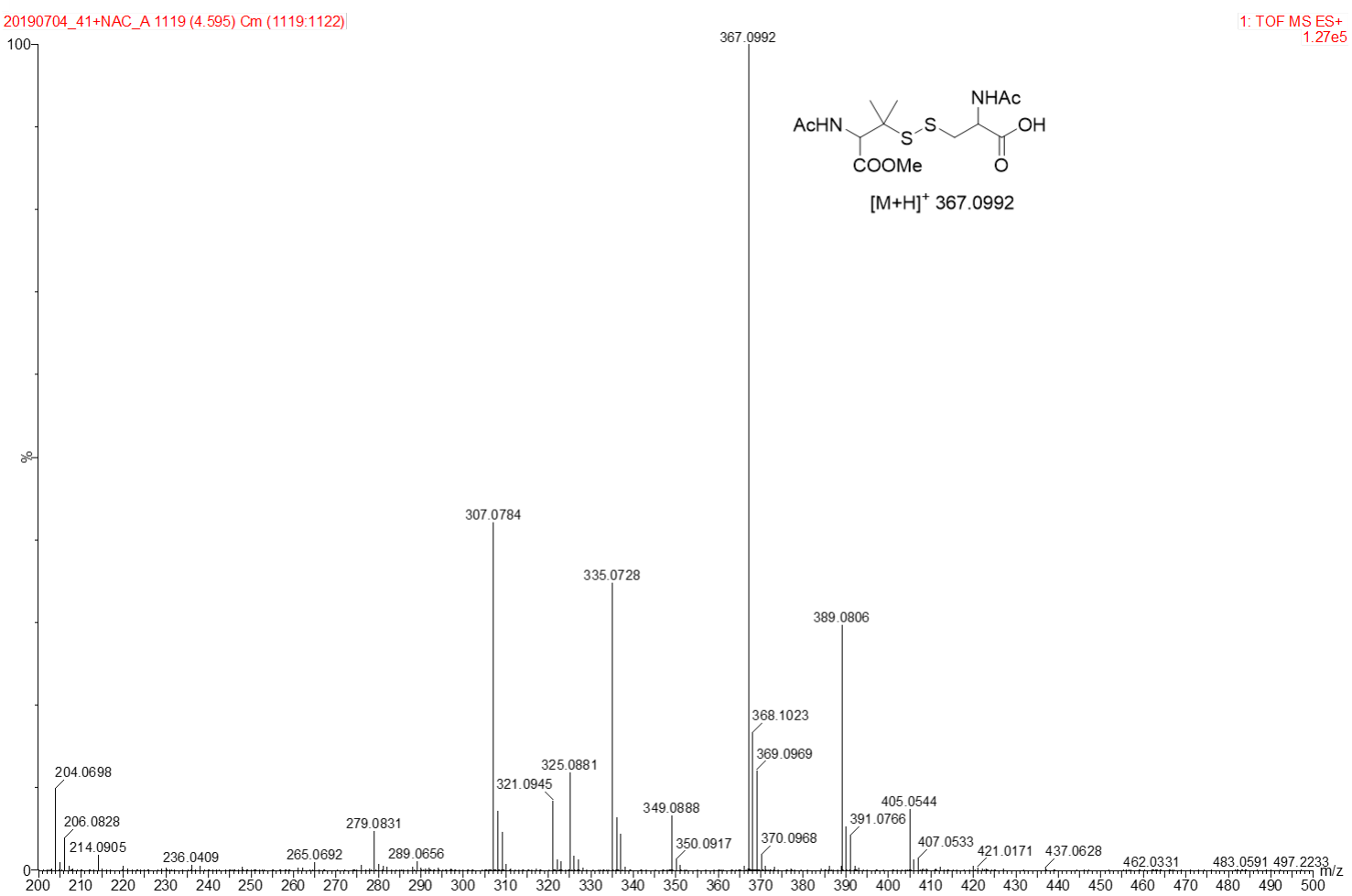

Figure S87. HRMS of the peak eluting at 4.60 min corresponding to unsymmetrical disulfide $\left(\mathrm{R}^{1} \mathrm{SSR}^{3}\right)$.

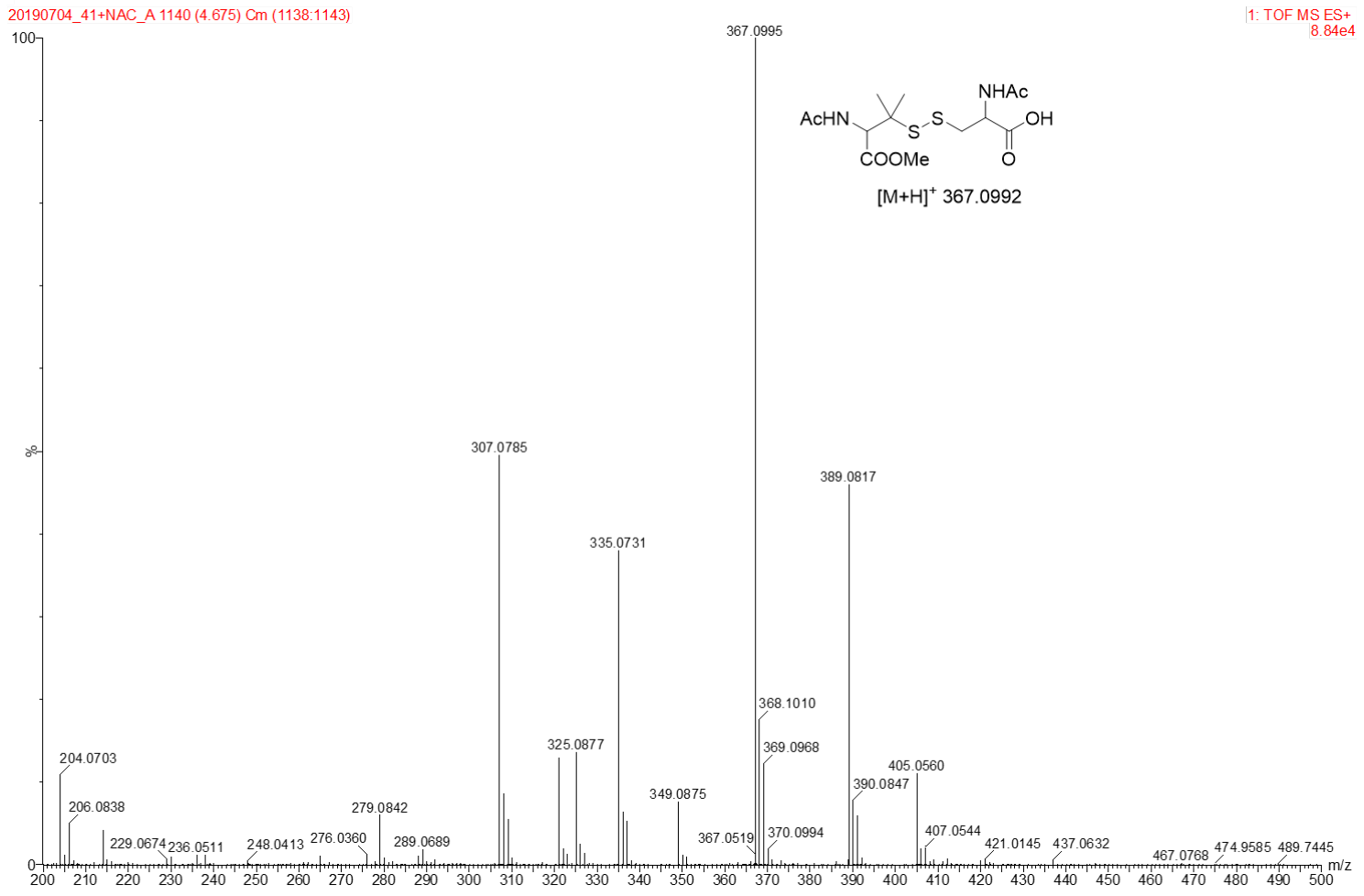

Figure S88. HRMS of the peak eluting at 4.68 min corresponding to unsymmetrical disulfide $\left(\mathrm{R}^{1} \mathrm{SSR}^{3}\right)$. 


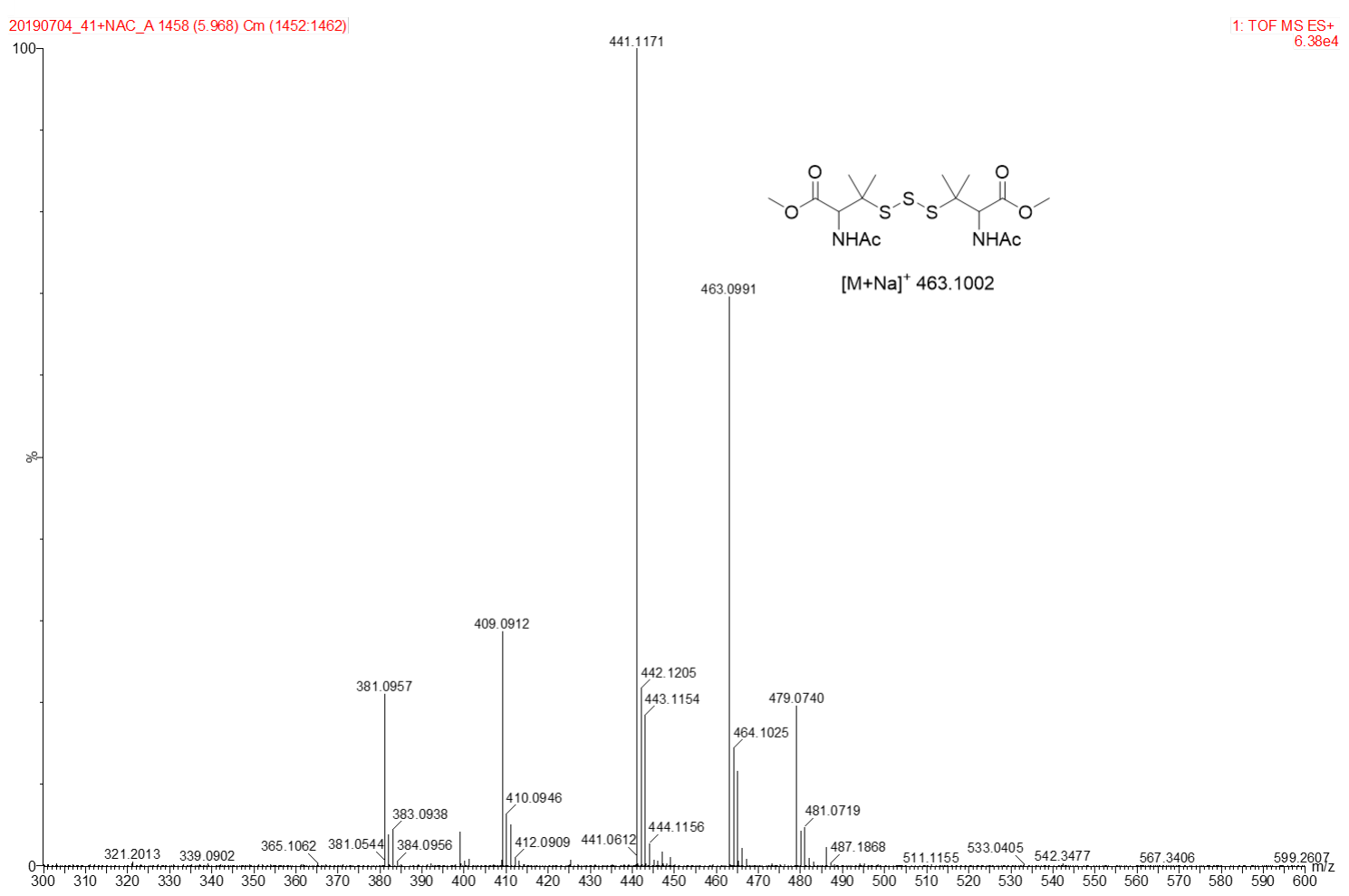

Figure S89. HRMS of the peak eluting at 5.97 min corresponding to symmetrical trisulfide $\left(\mathrm{R}^{1} \mathrm{SSSR}^{1}\right)$.

RSSH generation from precursor $7 \mathrm{~d}$ in the presence of NAC

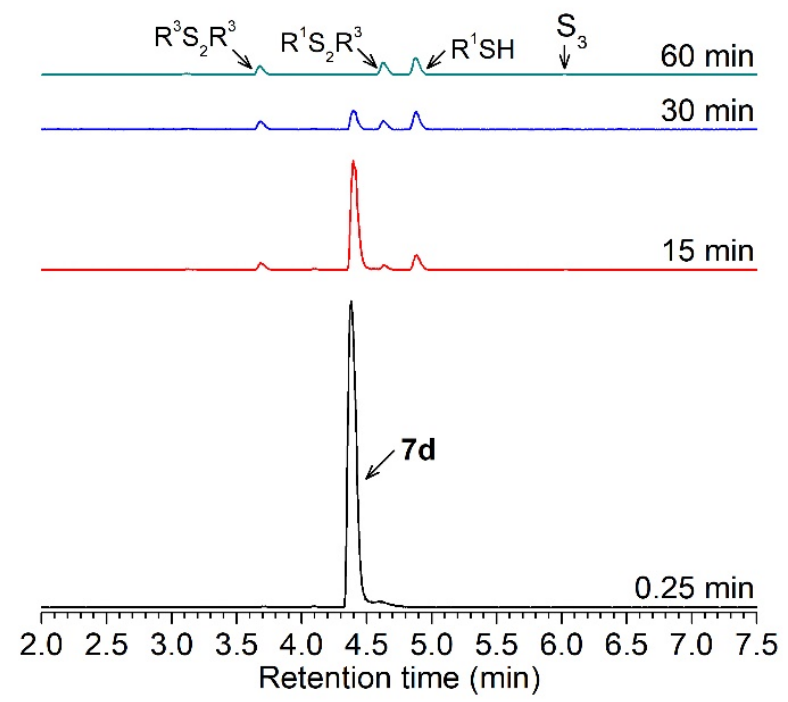

Figure S90. UPLC-MS chromatograms of RSSH generation from 7d $(100 \mu \mathrm{M})$ in the presence of NAC $(500 \mu \mathrm{M})$ incubated in $\mathrm{pH} 7.4$ ammonium bicarbonate $(50 \mathrm{mM})$ with DTPA $(100 \mu \mathrm{M})$ at $37{ }^{\circ} \mathrm{C}$. Aliquots $(200 \mu \mathrm{L})$ were taken at specified time points, quenched with $1 \%$ formic acid $(200 \mu \mathrm{L})$ and analyzed using UPLC-MS. A peak at 3.64 min attributed to $N$-acetyl cystine $\left(\mathrm{R}^{3} \mathrm{~S}_{2} \mathrm{R}^{3}\right)$ is observed under these conditions. A minor amount of RSSH-derived dialkyl trisulfides $\left(\mathrm{S}_{3}\right)$ formation indicates that the precursor $7 \mathbf{d}$ mainly reacts with NAC to produce the $\mathrm{R}^{1} \mathrm{~S}_{2} \mathrm{R}^{3}$, and the RSSH-generation path is minor under these conditions. 


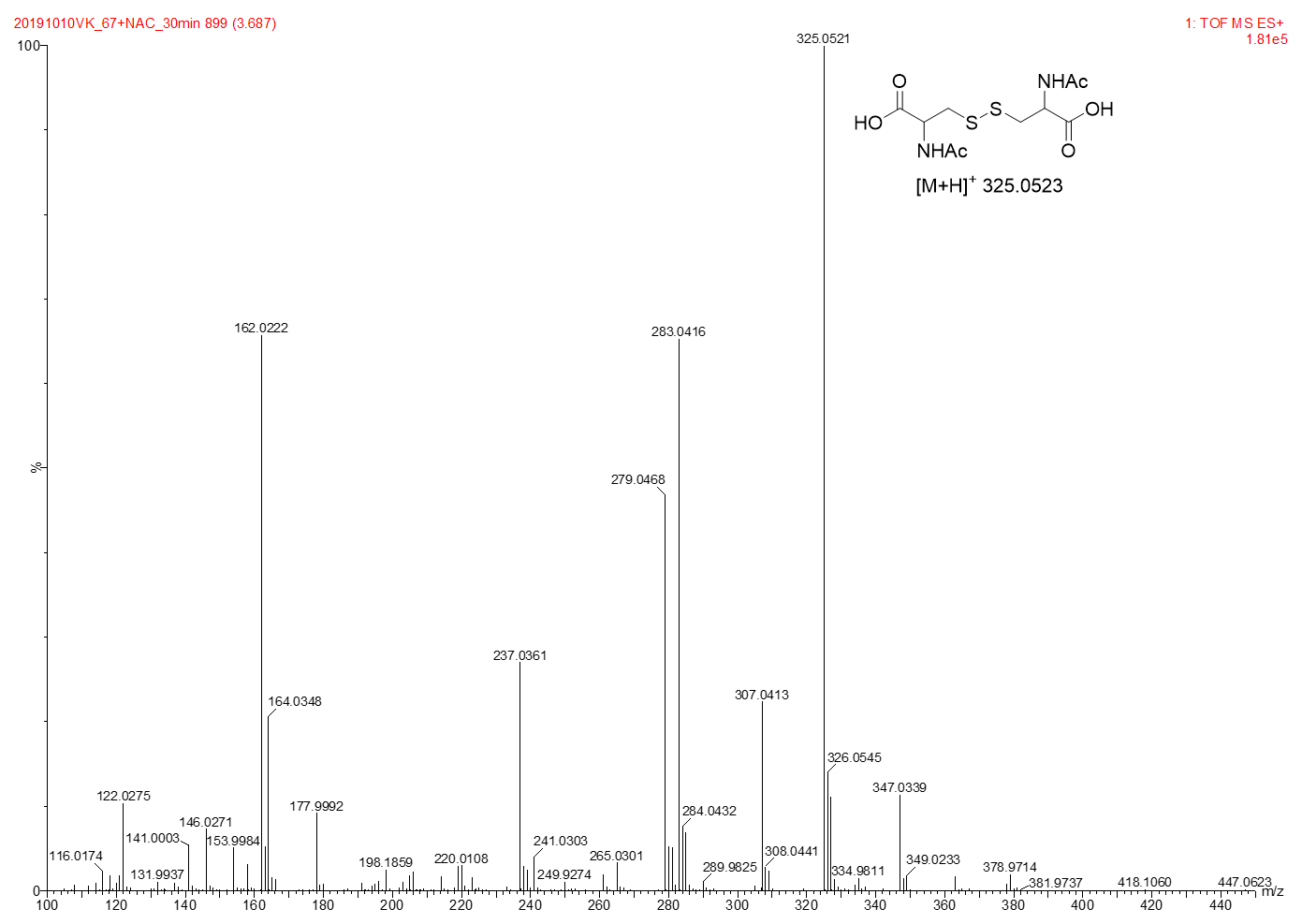

Figure S91. HRMS of the peak eluting at $3.69 \mathrm{~min}$ corresponding to $N$-acetyl cystine.

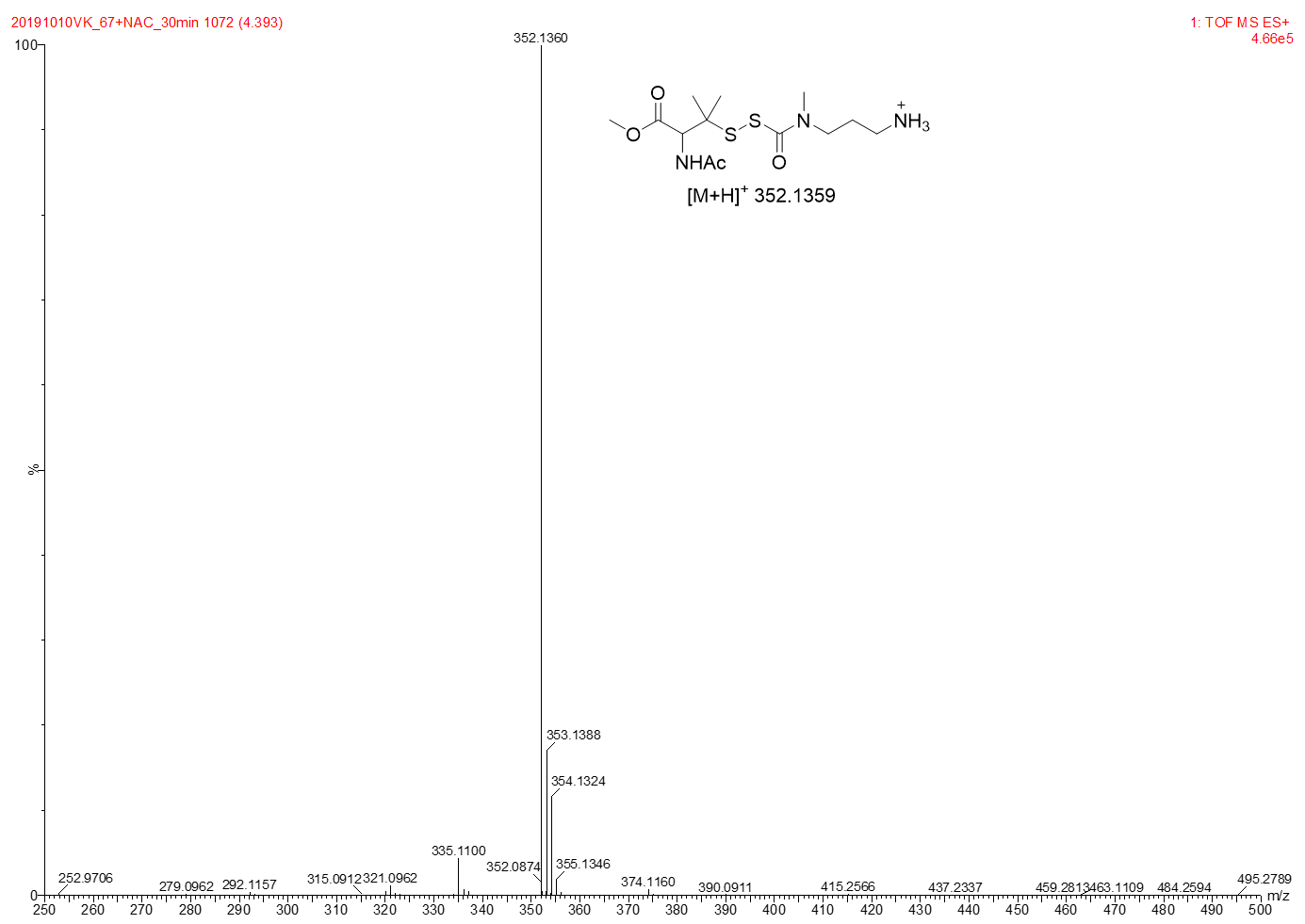

Figure S92. HRMS of the peak eluting at 4.39 min corresponding to precursor $7 \mathbf{d}$. 


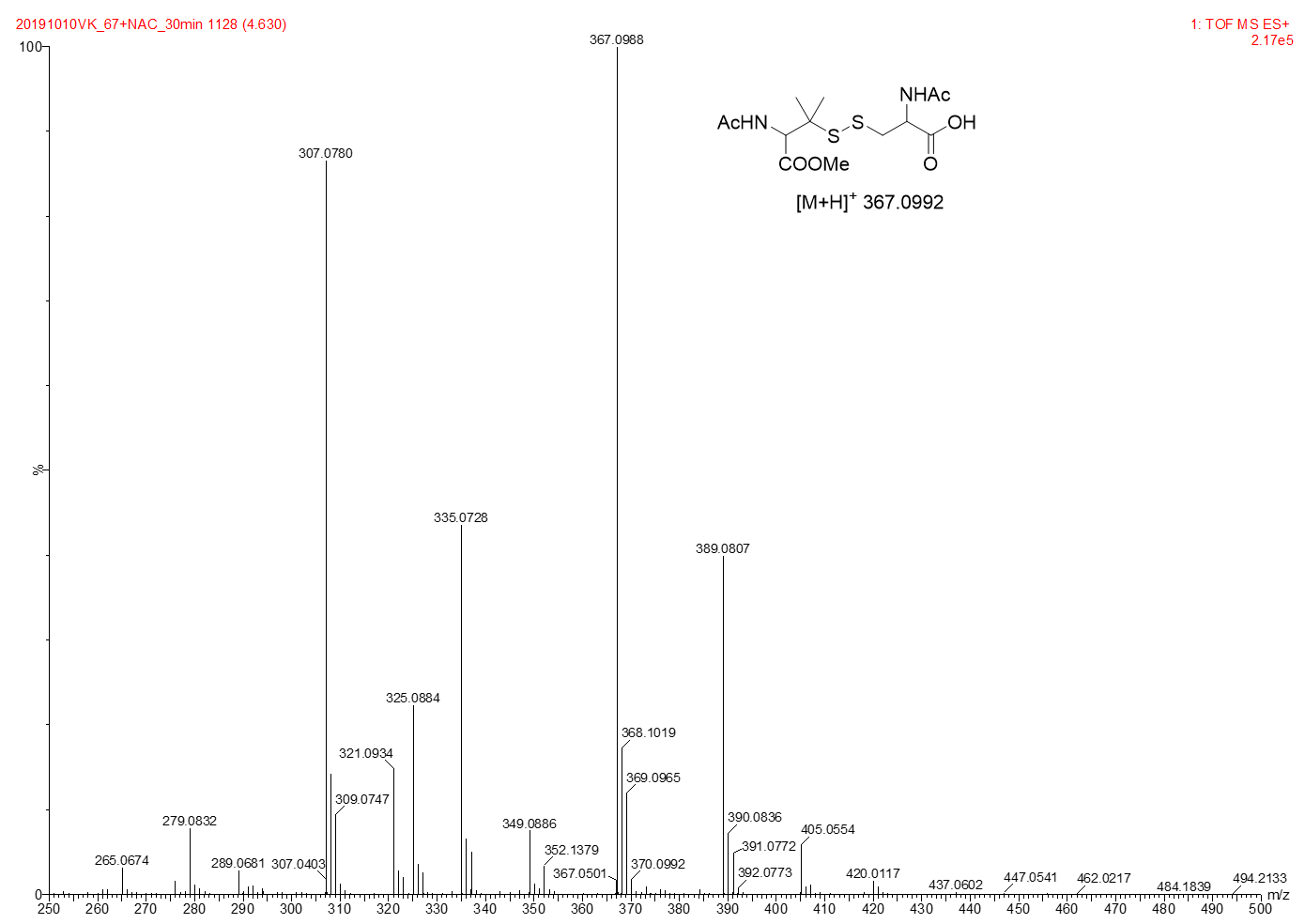

Figure S93. HRMS of the peak eluting at 4.63 min corresponding to unsymmetrical disulfide $\left(\mathrm{R}^{1} \mathrm{SSR}^{3}\right)$.

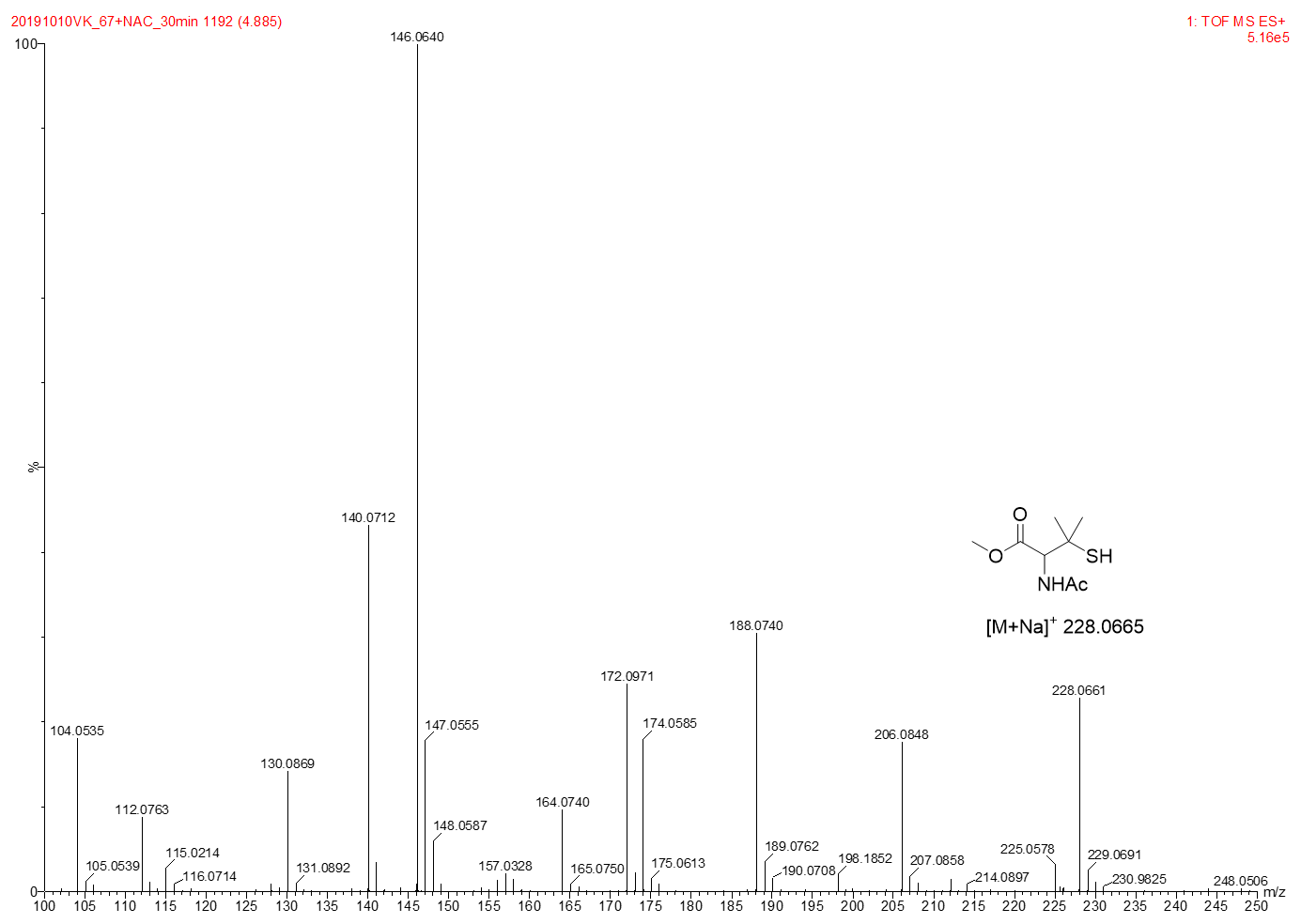

Figure S94. HRMS of the peak eluting at $4.89 \mathrm{~min}$ corresponding to $N$-acetyl penicillamine methyl ester. 


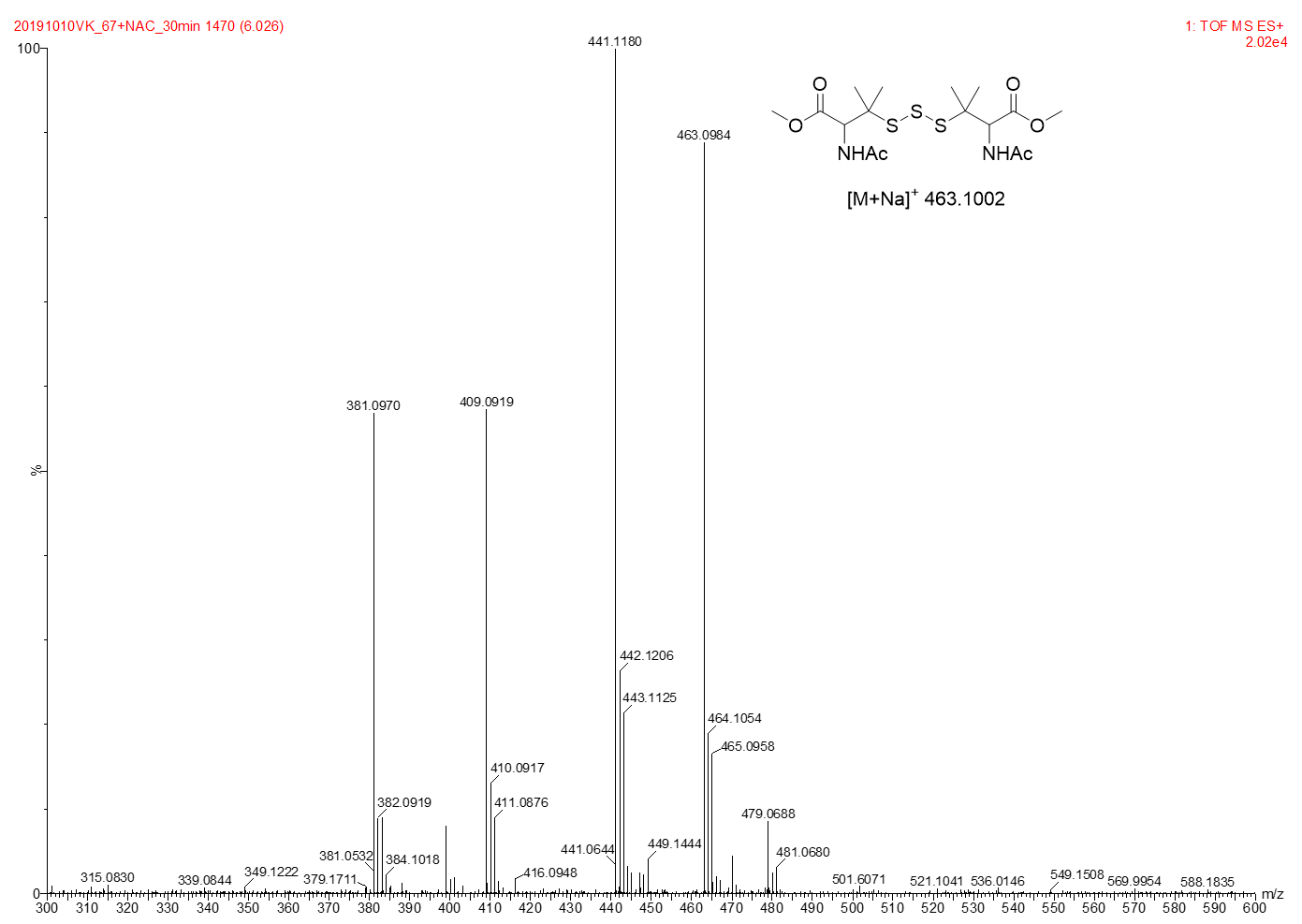

Figure S95. HRMS of the peak eluting at 6.01 min corresponding to symmetrical trisulfide $\left(\mathrm{R}^{1} \mathrm{SSSR}^{1}\right)$.

\section{Comparison of RSSH release from $7 \mathrm{~b}$ with NAC at pH 6.0 and 7.4}

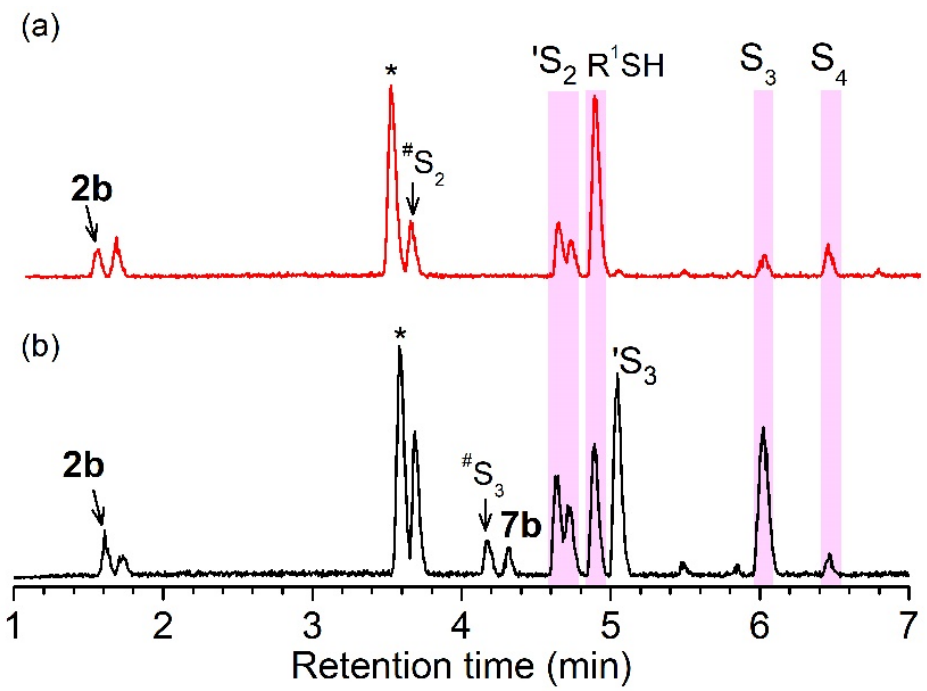

Figure S96. (a) RSSH generation from $7 \mathbf{b}(100 \mu \mathrm{M})$ in the presence of NAC $(500 \mu \mathrm{M})$ in $\mathrm{pH} 7.4$ ammonium bicarbonate $(50 \mathrm{mM})$ with DTPA $(100 \mu \mathrm{M})$ at $37{ }^{\circ} \mathrm{C}$ for $45 \mathrm{~min}$. (b) RSSH generation from $7 \mathbf{b}(100 \mu \mathrm{M})$ in the presence of NAC $(500 \mu \mathrm{M})$ in pH 6.0 ammonium acetate buffer $(50 \mathrm{mM})$ with DTPA $(100 \mu \mathrm{M})$ at $37^{\circ} \mathrm{C}$ for $12 \mathrm{~h}$. The presence of RSSH precursor peak after $12 \mathrm{~h}$ incubation at $\mathrm{pH} 6.0$ 
demonstrates slow RSSH release under acidic conditions. RSSH-derived symmetrical dialkyl polysulfide labeled as $\mathrm{S} 3$ and $\mathrm{S} 4\left(\mathrm{R}^{1} \mathrm{SS}_{\mathrm{n}} \mathrm{SR}^{1}, \mathrm{n}=1\right.$ and 2$)$, and unsymmetrical dialkyl polysulfide labeled as 'S2 and 'S3 $\left(\mathrm{R}^{1} \mathrm{SS}_{\mathrm{n}} \mathrm{SR}^{3}, \mathrm{n}=0\right.$ and 1$)$ formation were observed. $N$-acetyl cystine and $N$-acetyl cysteine trisulfide are labeled as ${ }^{\#} \mathrm{~S}_{2}$ and ${ }^{\#} \mathrm{~S}_{3}$, respectively. 4-Hydroxyphenyl acetamide, labeled as asterisk, is used as internal standard in these experiments.

\section{RSSH generation from precursor $7 \mathrm{~b}$ in the presence of glutathione}

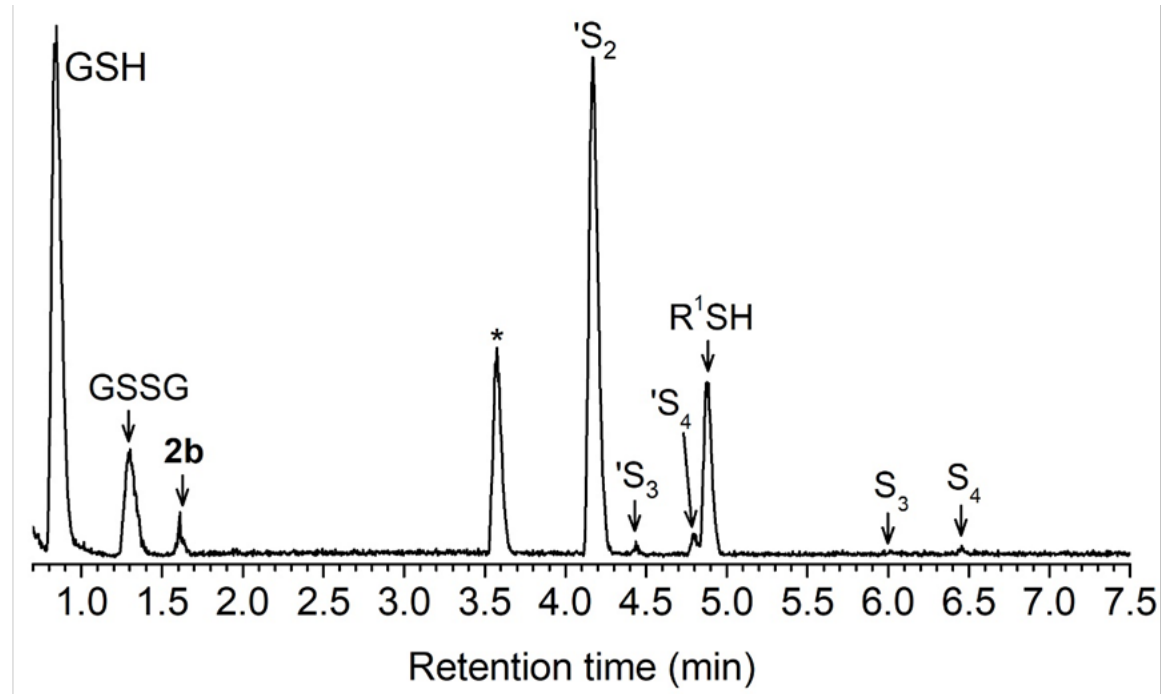

Figure S97. UPLC-MS chromatograms of RSSH generation from $7 \mathbf{b}(100 \mu \mathrm{M})$ in the presence of glutathione $(500 \mu \mathrm{M})$ incubated in $\mathrm{pH} 7.4$ ammonium bicarbonate $(50 \mathrm{mM})$ with DTPA $(100 \mu \mathrm{M})$ at 37 ${ }^{\circ} \mathrm{C}$ for $45 \mathrm{~min}$. The reaction mixture was quenched with $1 \%$ formic acid and analyzed by UPLC-MS. Under these conditions, $42 \pm 1 \mu \mathrm{M}$ of $\mathbf{2 b}$ formation is observed. RSSH-derived symmetrical dialkyl polysulfide labeled as $\mathrm{S} 3$ and $\mathrm{S} 4\left(\mathrm{R}^{1} \mathrm{SS}_{\mathrm{n}} \mathrm{SR}^{1}, \mathrm{n}=1-2\right)$, and unsymmetrical dialkyl polysulfide labeled as 'S2 to ' $\mathrm{S} 4\left(\mathrm{R}^{1} \mathrm{SS}_{\mathrm{n}} \mathrm{SR}^{3}, \mathrm{n}=0\right.$ - 2) formation are observed. 4-Hydroxyphenyl acetamide, labeled as asterisk, is used as internal standard in these experiments. 


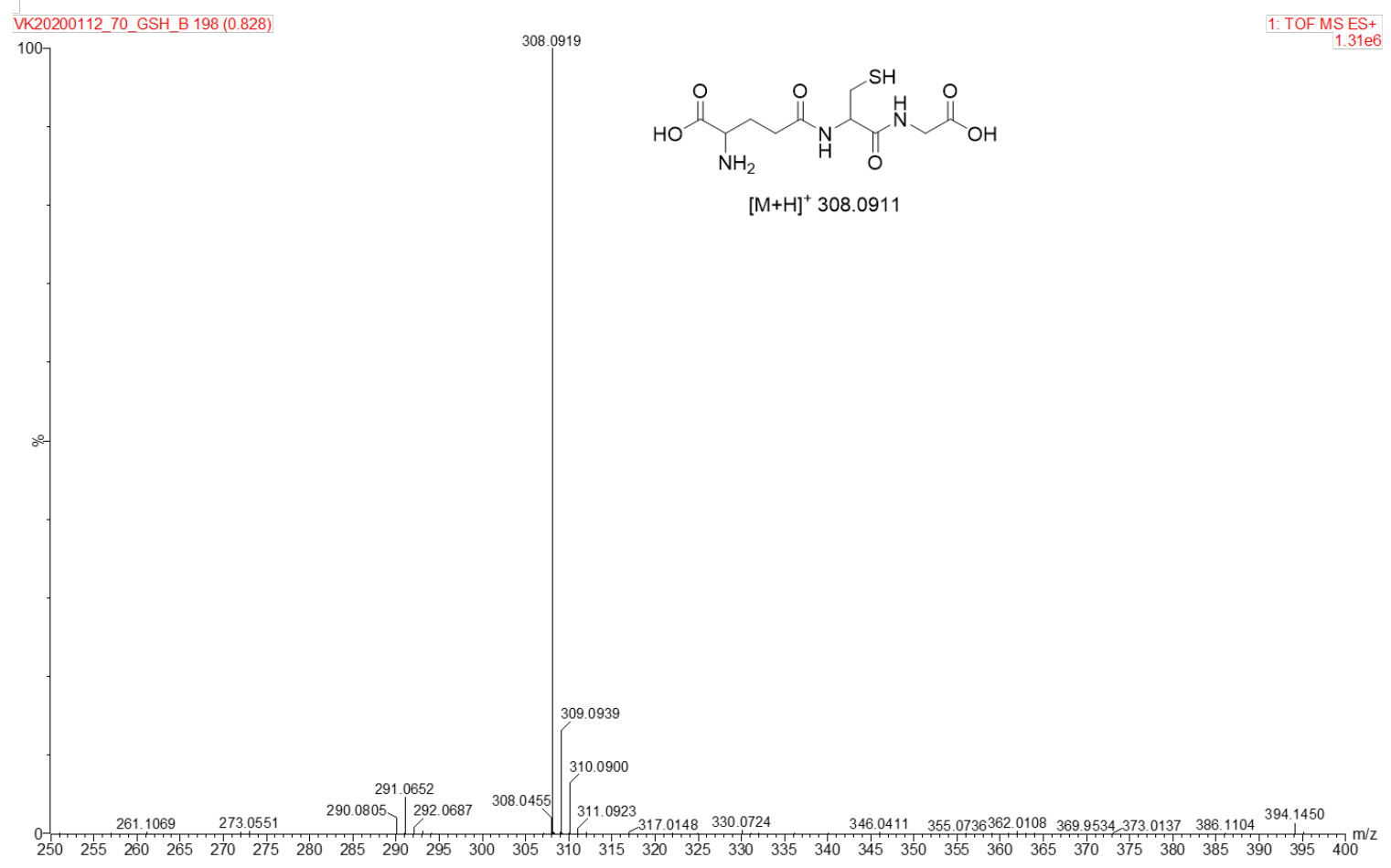

Figure S98. HRMS of the peak eluting at 0.83 min corresponding to glutathione.

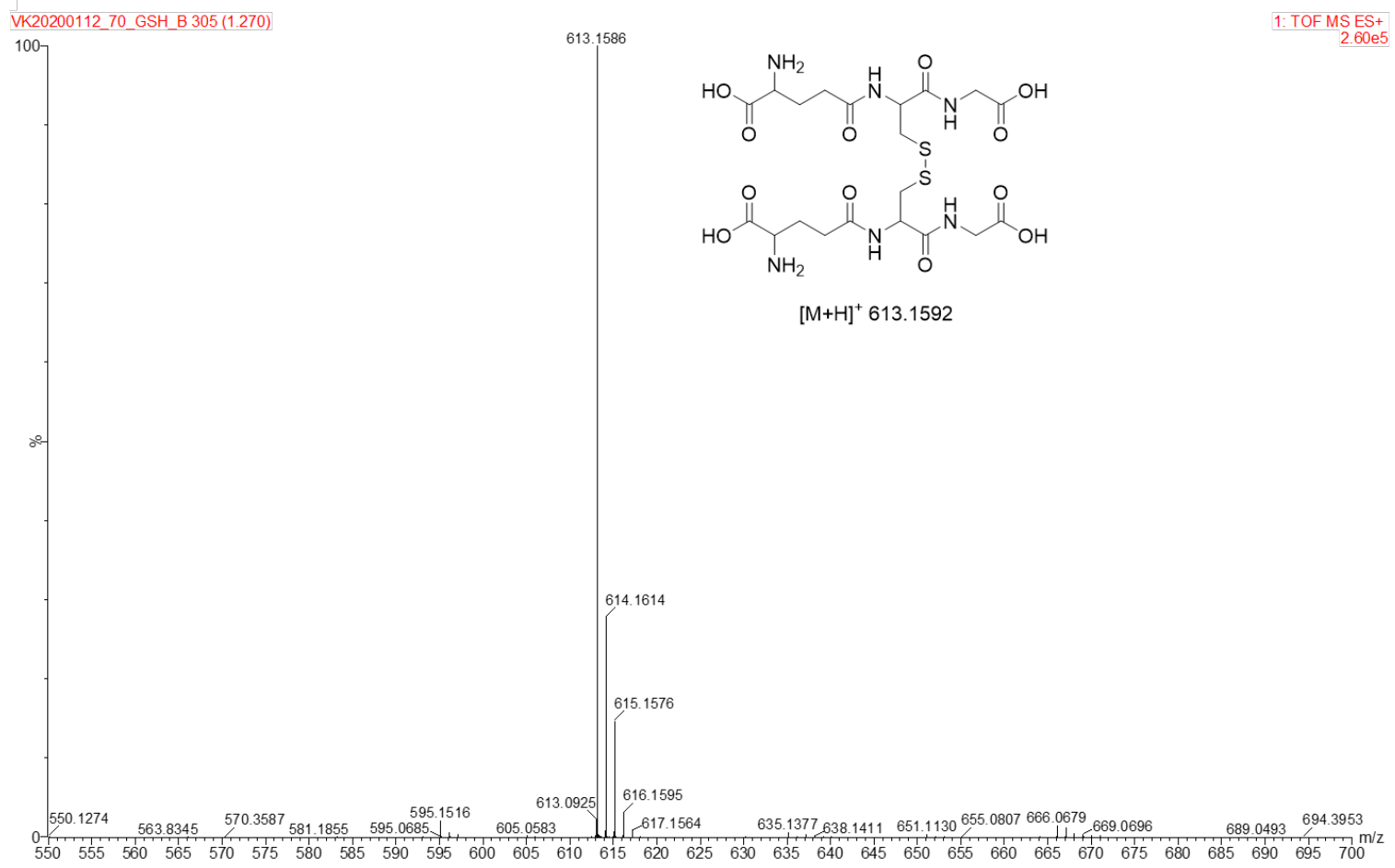

Figure S99. HRMS of the peak eluting at $1.27 \mathrm{~min}$ corresponding to glutathione disulfide. 


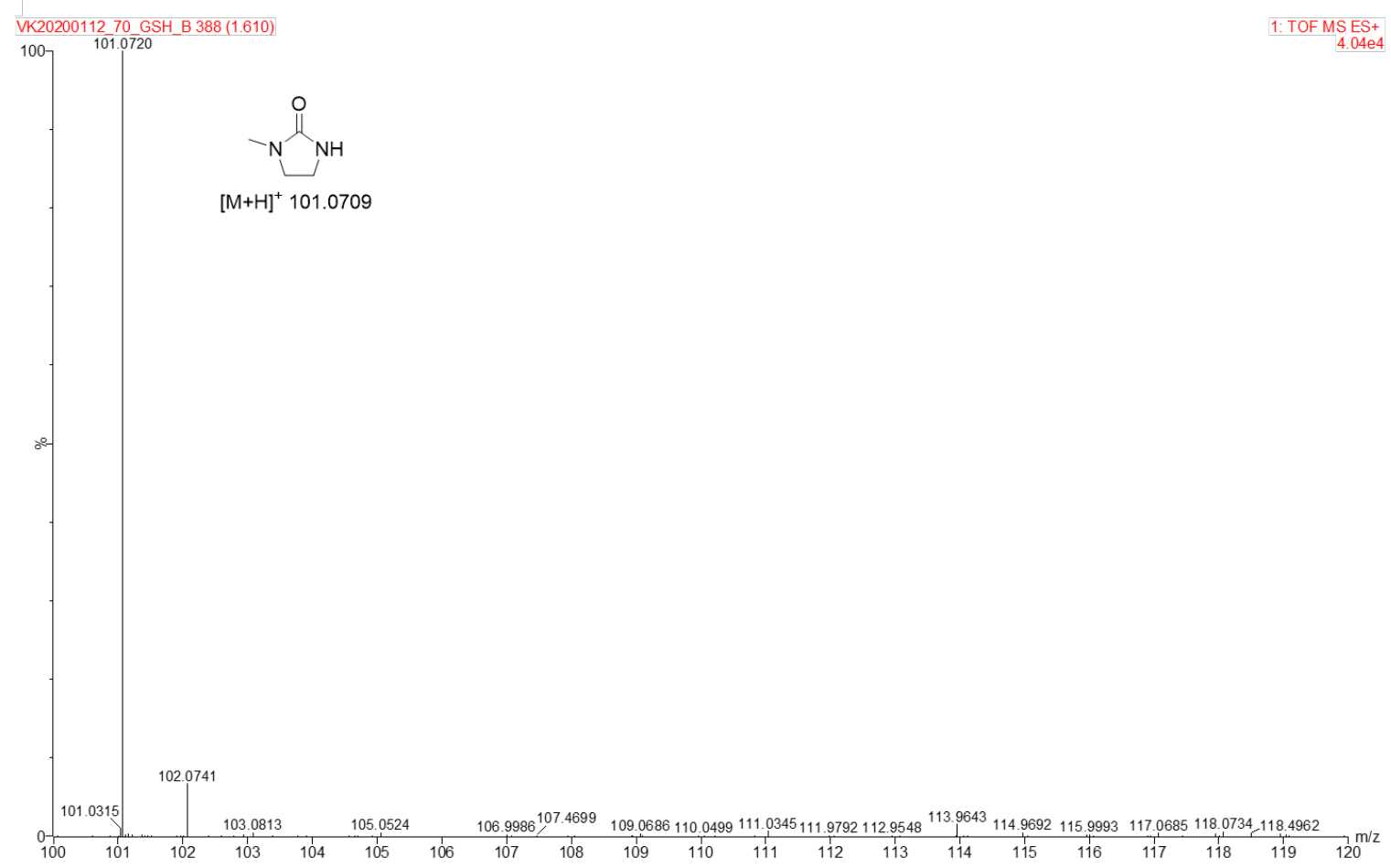

Figure S100. HRMS of the peak eluting at 1.61 min corresponding to $\mathbf{2 a}$.

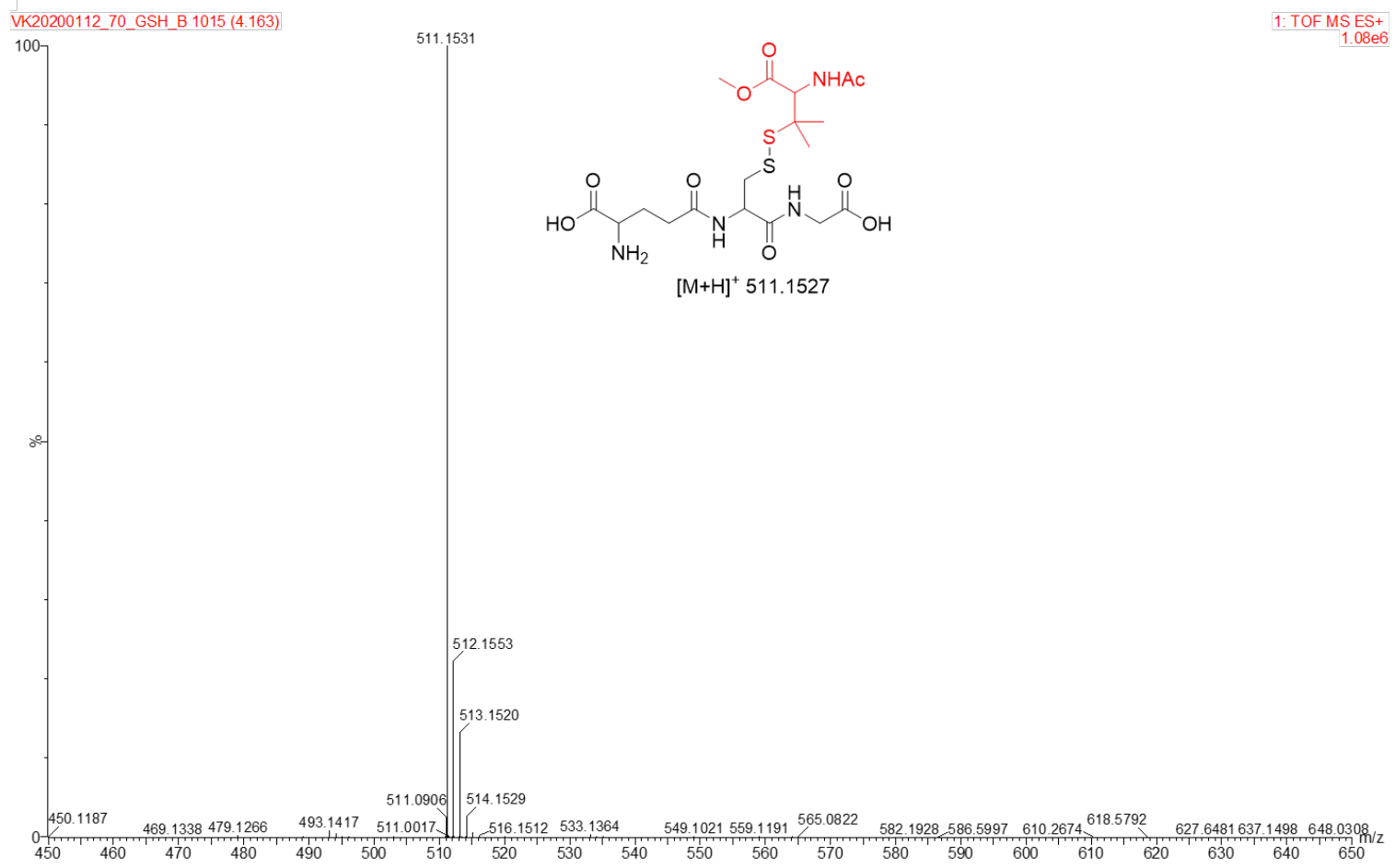

Figure S101. HRMS of the peak eluting at 4.16 min corresponding to unsymmetrical disulfide $\mathrm{R}^{1} \mathrm{SSR}^{3}$. 


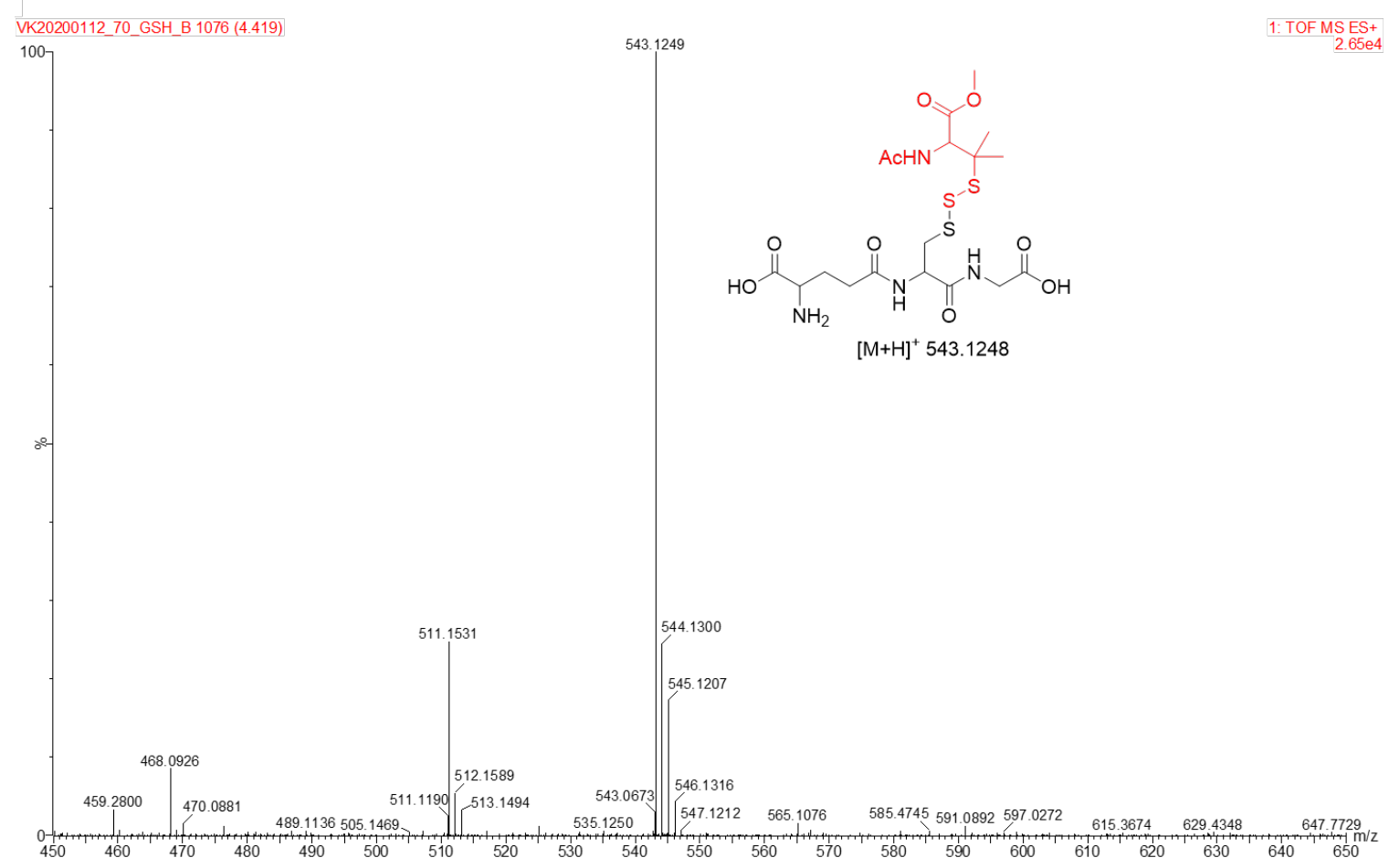

Figure S102. HRMS of the peak eluting at 4.42 min corresponding to unsymmetrical trisulfide $\mathrm{R}^{1} \mathrm{SSSR}^{3}$.

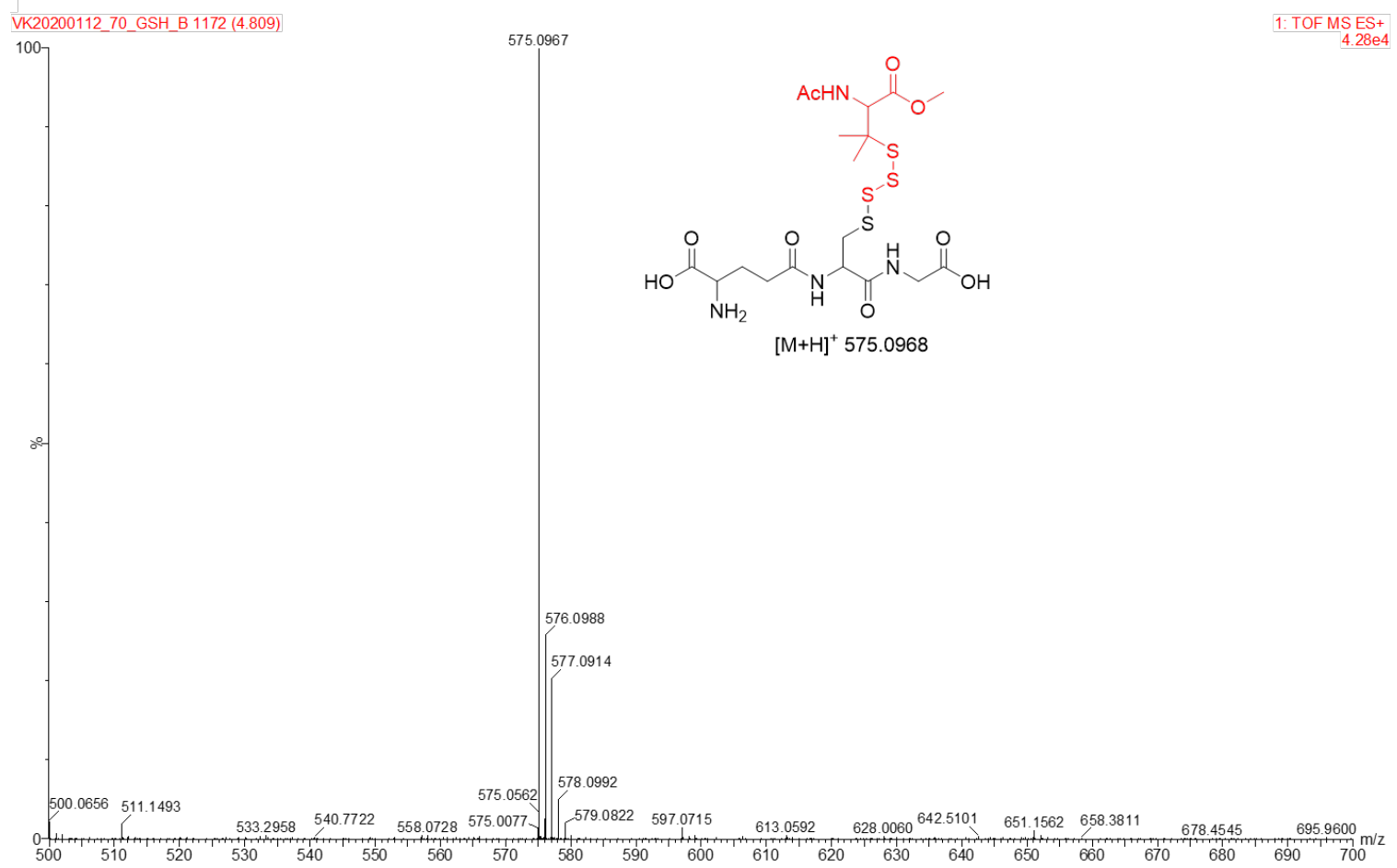

Figure S103. HRMS of the peak eluting at $4.81 \mathrm{~min}$ corresponding to unsymmetrical tetrasulfide $\mathrm{R}^{1} \mathrm{SS}_{2} \mathrm{SR}^{3}$. 


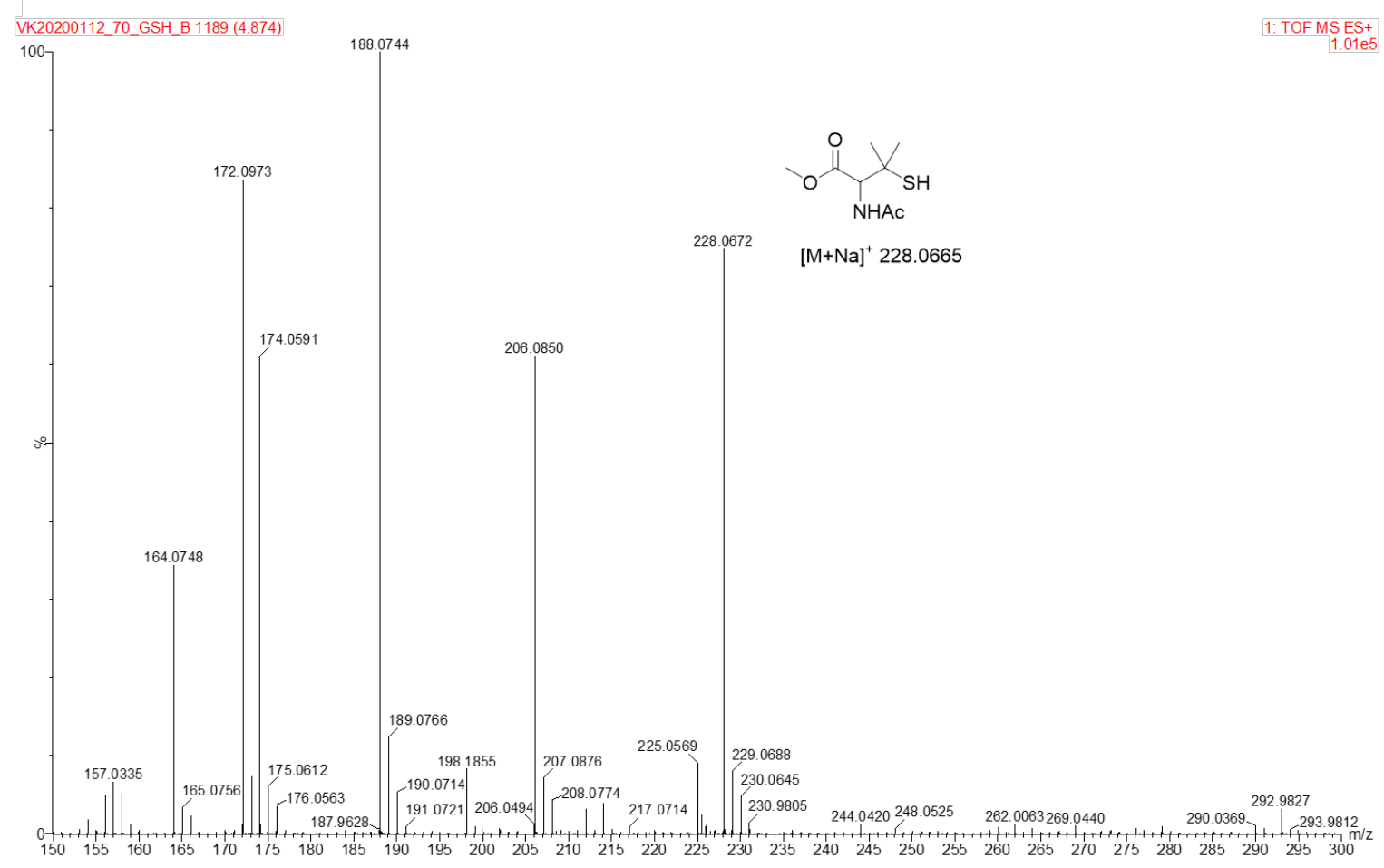

Figure S104. HRMS of the peak eluting at 4.87 min corresponding to $N$-acetyl-penicillamine methyl ester.

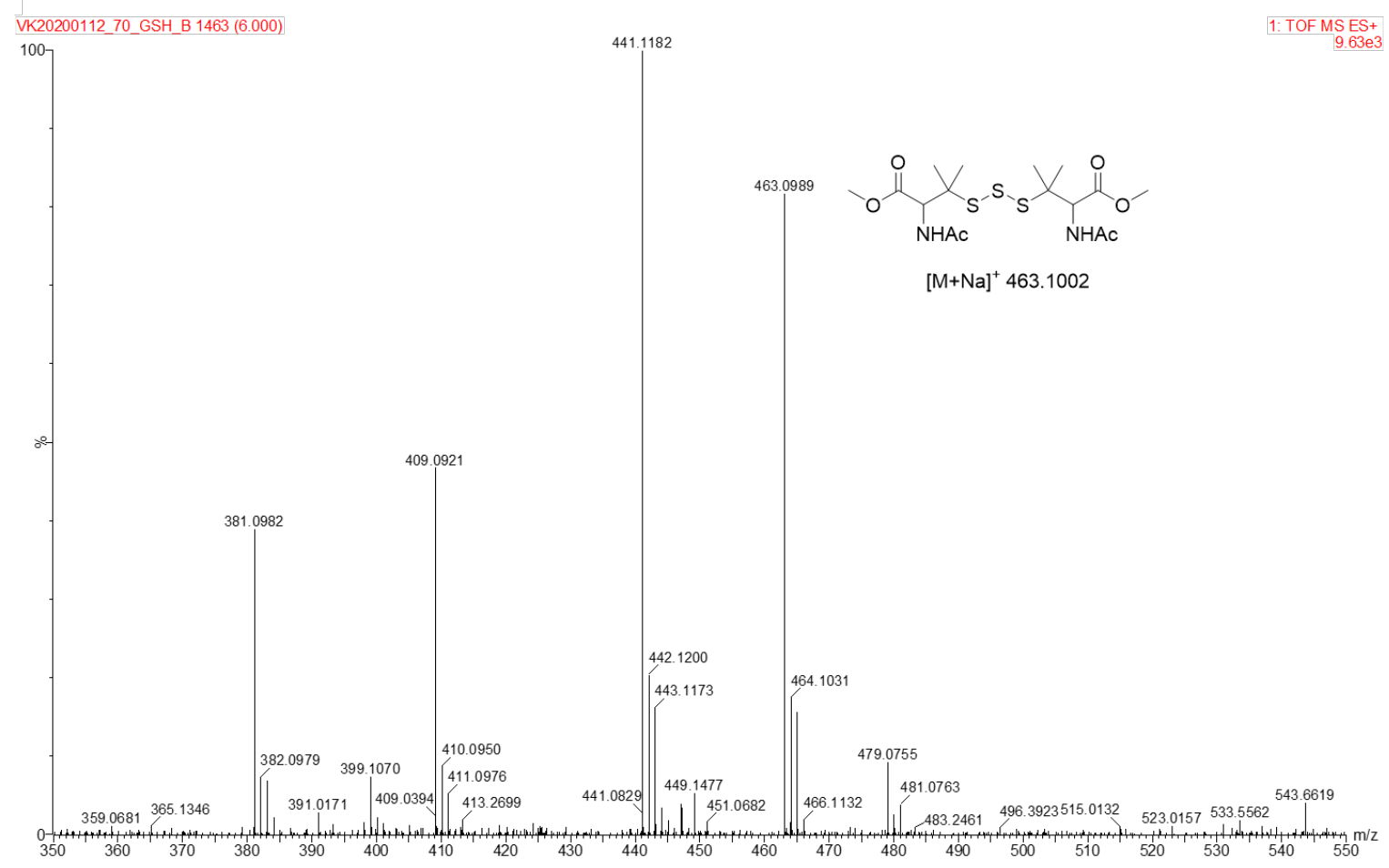

Figure S105. HRMS of the peak eluting at 4.87 min corresponding to symmetrical trisulfide $\mathrm{R}^{1} \mathrm{SSSR}^{1}$. 


\section{Analysis of COS release from $7 \mathrm{a}-\mathrm{d}$ in the presence of $\boldsymbol{N}$-acetyl-cysteine using MIMS}

COS was analyzed using a Hiden HPR-40 MIMS system with a sample cell and membrane probe that have been optimized to detect gases dissolved in aqueous solution as described previously. ${ }^{5}$ A stock solution of $N$-acetyl-cysteine $(25 \mathrm{mM})$ was prepared in DI water. RSSH precursor stock solutions $(5 \mathrm{mM})$ were prepared in DMSO. These solutions were degassed by purging with nitrogen for $10 \mathrm{~min}$ before COS release analysis. Typically, $20 \mathrm{~mL}$ phosphate buffer solution (10 $\mathrm{mM}$ ) was added to the sample cell, degassed and purged with a continuous flow of argon for 15 min. $N$-acetyl cysteine $(200 \mu \mathrm{L}, 25 \mathrm{mM})$ and RSSH precursor $(200 \mu \mathrm{L}, 5 \mathrm{mM})$ were then injected using a gas tight syringe and ion current at $\mathrm{m} / z 60\left(\mathrm{COS}^{+}\right)$were collected for $2 \mathrm{~h}$ (source pressure was approximately $1 \times 10^{-7}$ to $5 \times 10^{-7}$ Torr).

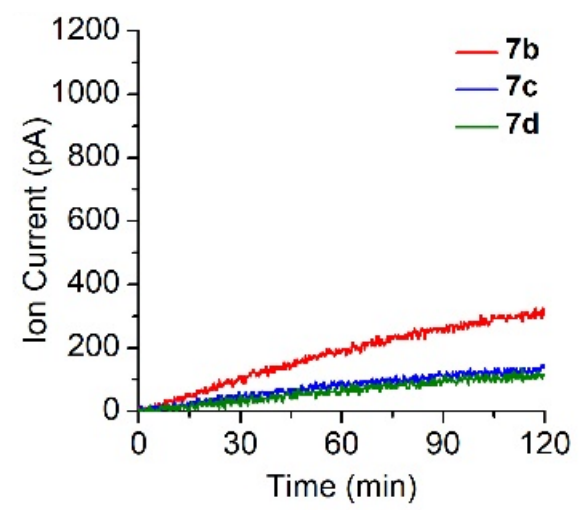

Figure S106. MIMS measurement of COS generated from $7 \mathbf{b}-\mathbf{d}(50 \mu \mathrm{M})$ with NAC $(0.25 \mathrm{mM}, 5$ equiv. $)$ in $\mathrm{pH} 6.0$ phosphate buffer containing DTPA $(100 \mu \mathrm{M})$ at $37^{\circ} \mathrm{C}$.

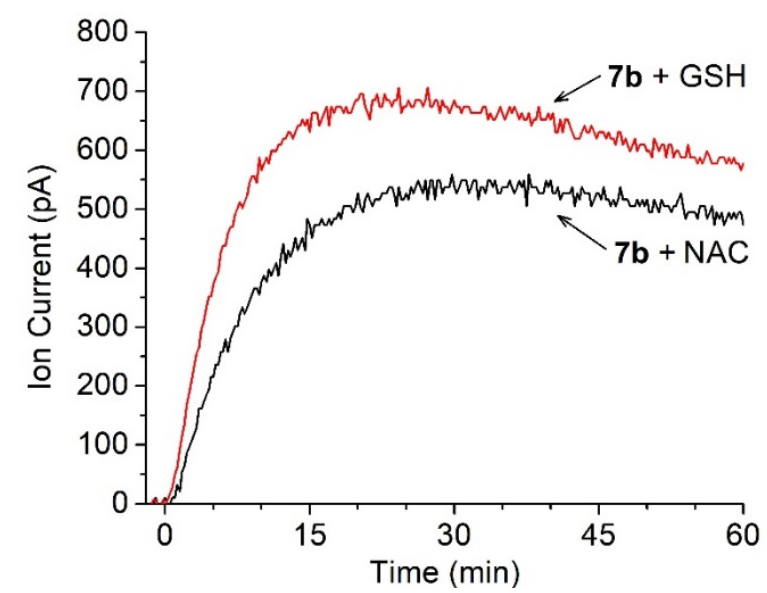

Figure S107. COS measurement using MIMS released from $7 \mathbf{b}(50 \mu \mathrm{M})$ with NAC and GSH $(0.25 \mathrm{mM}$, 5 equiv. $)$ in $\mathrm{pH} 7.4$ phosphate buffer saline $(10 \mathrm{mM})$ with DTPA $(100 \mu \mathrm{M})$ at $37^{\circ} \mathrm{C}$. 


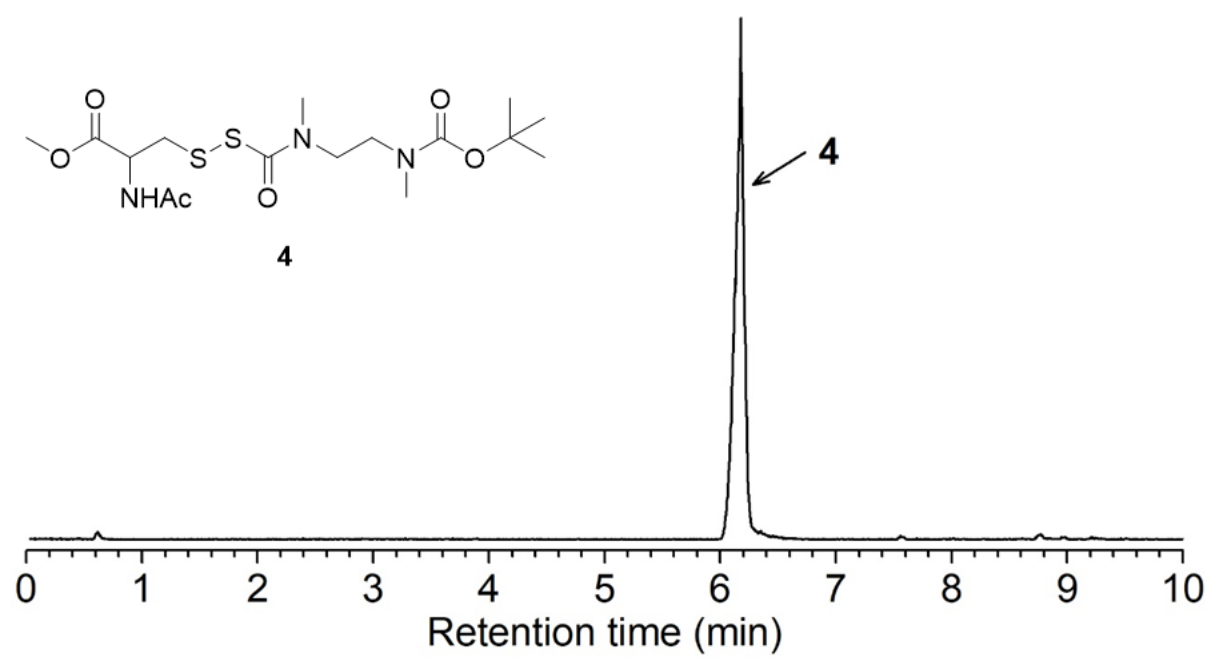

Figure S108. UPLC-MS chromatogram of compound $4(10 \mu \mathrm{M})$ shows only one peak demonstrating the lack of impurity.

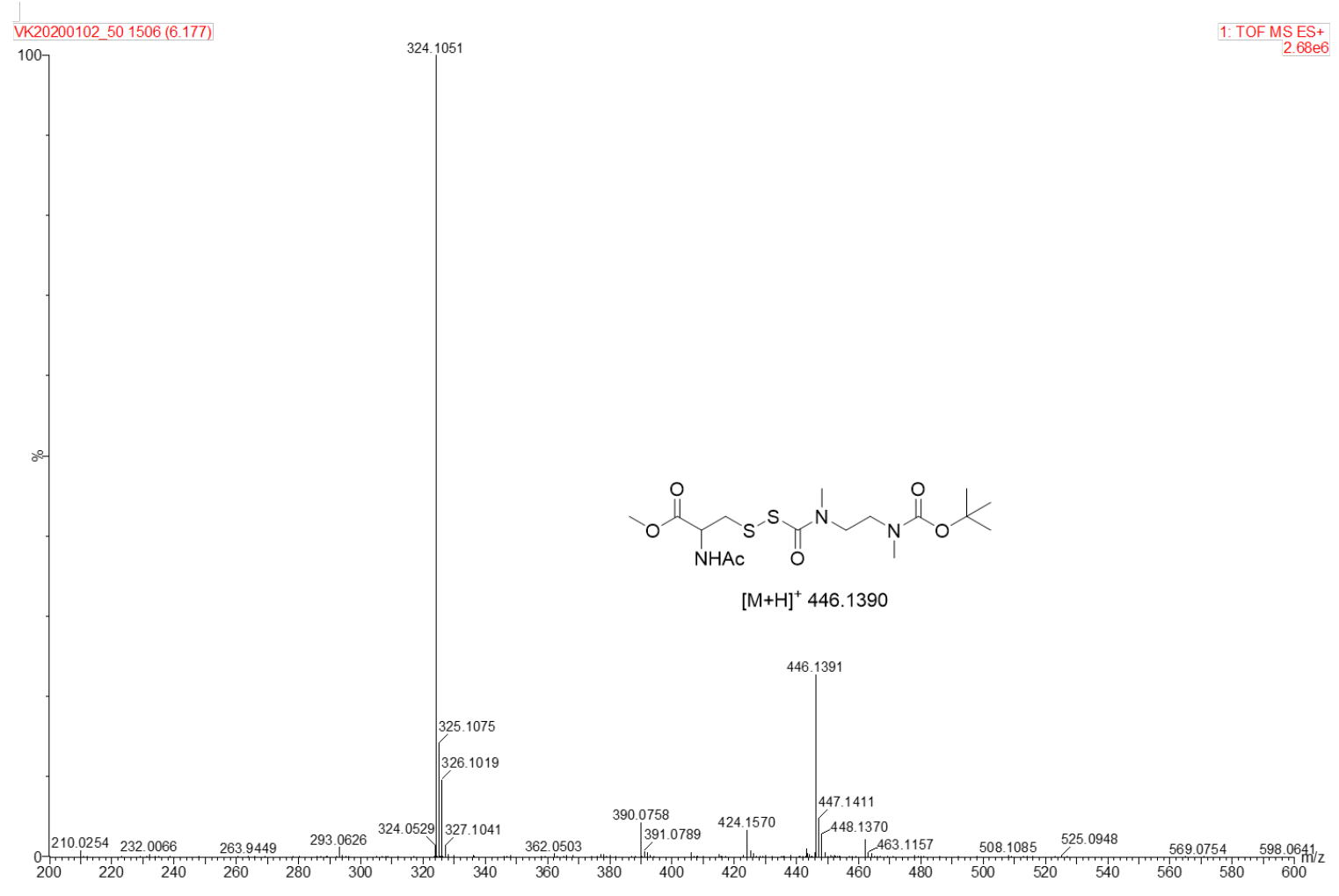

Figure S109. HRMS of the peak eluting at 6.18 min corresponding to 4. 


\section{Culture of cells}

H9c2(2-1) embryonic rat heart myoblasts were obtained from the American Type Culture Collection. Cells were grown in Dulbecco's minimal essential medium (DMEM), supplemented with fetal bovine serum (FBS) $10 \%$, penicillin $100 \mathrm{U} / \mathrm{mL}$ and streptomycin $100 \mu \mathrm{g} / \mathrm{mL}$. They were propagated in T75-flasks, split before reaching $70-80 \%$ confluence (usually every day or every second day), and used within 11 passages. Cells were passaged to tissue culture treated 96well microtiter plates at the specified density in $180 \mu \mathrm{L}$ volumes and incubated for $24 \mathrm{~h}$.

\section{Cytotoxicity study of $7 \mathrm{~b}$}

Cells were seeded at a density of $1 \times 10^{4}$ cells/well. After $24 \mathrm{~h}$, the media was replaced and compound added in $20 \mu \mathrm{L}$ volumes using DMSO: $\mathrm{H}_{2} \mathrm{O}(<0.01 \% \mathrm{DMSO})$ as the vehicle. Cells were incubated for an additional $24 \mathrm{~h}$ before media was removed. Then, $100 \mu \mathrm{L}$ of media containing 3 $\mu \mathrm{M}$ Sytox Green nucleic acid stain (Invitrogen) was added and the cells were incubated for $2 \mathrm{~h}$ before fluorescence readings were obtained at $485_{\mathrm{Ex}} / 538_{\mathrm{Em}}$ (Step 1). Finally, an additional $100 \mu \mathrm{L}$ of media containing $3 \mu \mathrm{M}$ Sytox and $0.2 \%$ Triton X-100 was added in order to permeabilize all cells and incubated for $1 \mathrm{~h}$ before fluorescence values measured (Step 2). The relative \% cells surviving was calculated as a $100 \%$ minus the ratio of the fluorescence value of Step 1 over Step $2\left(\%\right.$ cells surviving $=100 \%-\left(\mathrm{FL}_{538}(\right.$ Step 1$) / \mathrm{FL}_{538}($ Step 2$\left.)\right)$.

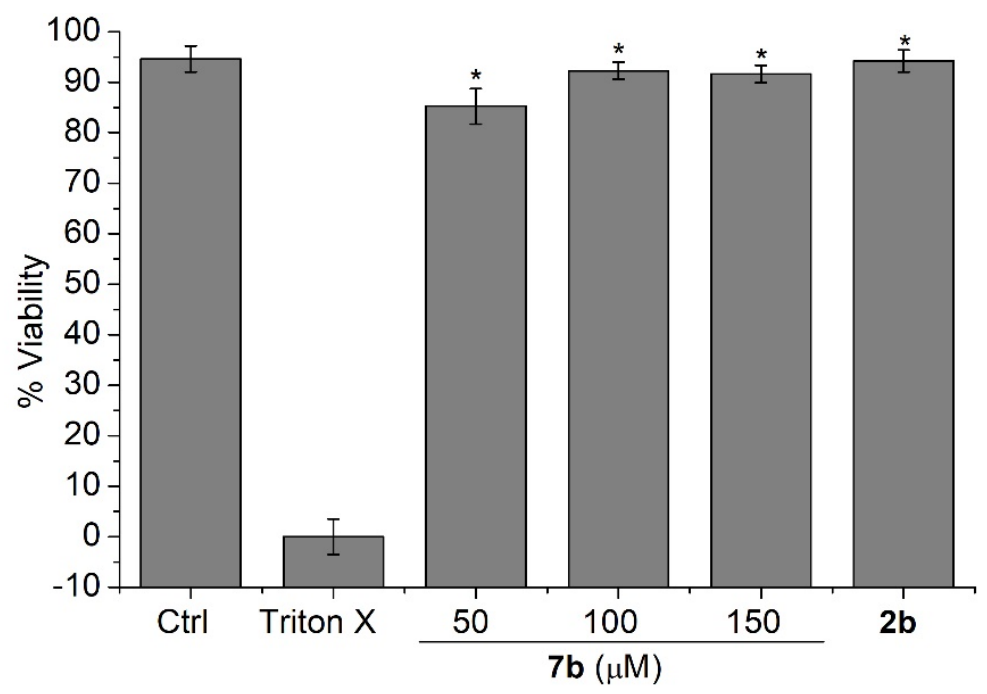

Figure S110. Cell viability assay conducted on H9c2 cells with Precursor 7b (50,100 and $150 \mu \mathrm{M})$ and byproduct $\mathbf{2 b}(150 \mu \mathrm{M})$ using Sytox Green nucleic acid stain. Results are expressed as the mean \pm SEM (n $=5$ for each treatment group) with 3 independent experiments. ${ }^{*} \mathrm{P}<0.0001$ as compared to Triton $\mathrm{X}-100$ control. 


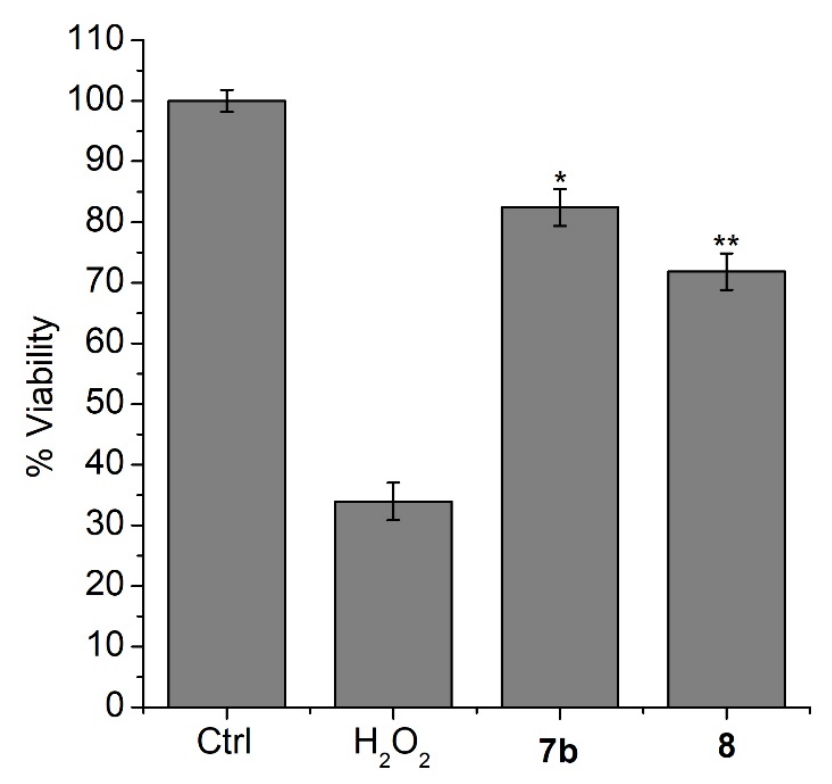

Figure S111. Results from H9c2 cardiac myoblasts pretreated with the RSSH precursor $7 \mathbf{b}(150 \mu \mathrm{M})$ and the COS precursor $8(150 \mu \mathrm{M})$ for $2 \mathrm{~h}$ followed by exposure to $\mathrm{H}_{2} \mathrm{O}_{2}(200 \mu \mathrm{M})$ for $2 \mathrm{~h}$. Quantification of cytotoxicity was carried out using Sytox Green nucleic acid stain. Results are expressed as the mean \pm SEM ( $\mathrm{n}=5$ for each treatment group) with five independent experiments. $* \mathrm{P}<0.001$ for comparisons with the $\mathrm{H}_{2} \mathrm{O}_{2}$ treatment group; when $7 \mathbf{b}$ compared with the COS precursor $\mathbf{8}$, ** $\mathrm{P}<0.05$.

\section{$\mathrm{H} 9 \mathrm{c} 2$ cell protection by precursor $7 \mathrm{~b}$ from $\mathrm{H}_{2} \mathrm{O}_{2}$-mediated oxidative stress Cell Counting Kit-8 (CCK-8) $6-8$}

Cells were seeded at a density of $5 \times 10^{3}$ cells/well. After $24 \mathrm{~h}$, precursor $7 \mathbf{b}$ or byproduct $2 \mathbf{b}$ was added at $20 \mu \mathrm{L}$ volumes using DMSO: $\mathrm{H}_{2} \mathrm{O}(<0.01 \%$ DMSO as the vehicle). Cells were incubated for $2 \mathrm{~h}$ before media was removed and the cells gently washed with PBS (pH 7.4). Then, $180 \mu \mathrm{L}$ of fresh media and $20 \mu \mathrm{L} \mathrm{H}_{2} \mathrm{O}_{2}$ diluted into $\mathrm{H}_{2} \mathrm{O}$ were added and cells were incubated for an additional $2 \mathrm{~h}$. At the completion of $\mathrm{H}_{2} \mathrm{O}_{2}$ exposure, each well is carefully washed 3 times with PBS ( $\mathrm{pH}$ 7.4) before adding $100 \mu \mathrm{L}$ of media, without-FBS, containing $10 \% \mathrm{v} / \mathrm{v}$ CCK-8 (Dojindo) and incubated for $3 \mathrm{~h}$ prior to obtaining absorbance values at $450 \mathrm{~nm}$. The relative $\%$ viability was calculated as 100 times the ratio of the $\mathrm{Abs}_{450}$ (pretreated, $\mathrm{H}_{2} \mathrm{O}_{2}$-exposed) over $\mathrm{Abs}_{450}$ (vehicletreated, non $\mathrm{H}_{2} \mathrm{O}_{2}$-exposed).

\section{$\underline{\text { Sytox Green nucleic acid stain }}{ }^{9}$}

Cells were seeded at a density of $1 \times 10^{4}$ cells/well. After $24 \mathrm{~h}$, precursor $7 \mathbf{b}$ or byproduct $\mathbf{2 b}$ is added in $20 \mu \mathrm{L}$ volumes using DMSO: $\mathrm{H} 2 \mathrm{O}(<0.01 \%$ DMSO $)$. Cells were incubated for $2 \mathrm{~h}$ before media was removed and the cells gently washed with PBS (pH 7.4). Then, $180 \mu \mathrm{L}$ of fresh media and $20 \mu \mathrm{L} \mathrm{H}_{2} \mathrm{O}_{2}$ diluted in $\mathrm{H}_{2} \mathrm{O}$ were added before cells were incubated for an additional $1 \mathrm{~h}$. After removing this media, $100 \mu \mathrm{L}$ of media containing $3 \mu \mathrm{M}$ Sytox Green nucleic acid stain was added, and the cells incubated for $2 \mathrm{~h}$ before fluorescence readings were obtained at $485_{\mathrm{Ex}} / 538_{\mathrm{Em}}$ (Step 1). Finally, an additional $100 \mu \mathrm{L}$ of media containing $3 \mu \mathrm{M}$ Sytox and $0.2 \%$ Triton X-100 was added in order to permeabilize all cells and incubated for $1 \mathrm{~h}$ before fluorescence values measured (Step 2 ). The relative $\%$ cells surviving was calculated as a $100 \%$ minus the ratio of the fluorescence value of Step 1 over Step 2 (\% cells surviving $=100 \%-\left(\mathrm{FL}_{538}\right.$ (Step 1)/ FL 538 (Step 2)). 
Fluorescence values for vehicle-treated, non- $\mathrm{H}_{2} \mathrm{O}_{2}$-exposed wells were treated as background cell death and this value is added to the \% cell survival for each subsequent group.

\section{Isolated perfused heart protocol and infarct size determination ${ }^{10-12}$}

Male C57BL/6J mice obtained from Jackson Laboratories (Bar Harbor, ME, USA) were used for all experiments. Mice were between 12 and 14 weeks of age at the time of experimentation. All animals received humane care in compliance with the "Principles of Laboratory Animal Care" formulated by the National Society for Medical Research and the "Guide for the Care and Use of Laboratory Animals" published by the US National Institutes of Health. The Animal Care and Use Committee from Johns Hopkins University approved of this study.

After anticoagulation with heparin and cervical dislocation, a thoracotomy was performed and the heart was quickly excised and placed in ice-cold Krebs-Henseleit buffer (in mmol/L: 11.1 Dglucose, $1.2 \mathrm{MgSO}_{4}, 1.2 \mathrm{KH}_{2} \mathrm{PO}_{4}, 4.7 \mathrm{KCl}, 118 \mathrm{NaCl}_{2} \mathrm{CaCl}_{2}, 25 \mathrm{NaHCO}_{3}$ ). The aorta was cannulated, and the heart was perfused with Krebs-Henseleit buffer (oxygenated with $95 \% \mathrm{O}_{2} / 5 \%$ $\mathrm{CO}_{2}$ and maintained at $\mathrm{pH} 7.4$ ) in retrograde fashion at a constant pressure of $80 \mathrm{~mm} / \mathrm{Hg}$ at $37{ }^{\circ} \mathrm{C}$. After baseline equilibration for $20 \mathrm{~min}$, mouse hearts were subjected to $20 \mathrm{~min}$ of no-flow global ischemia followed by $90 \mathrm{~min}$ of reperfusion. Pharmacological postconditioning with $7 \mathbf{b}(100 \mu \mathrm{M})$ was performed at the onset of reperfusion for $7 \mathrm{~min}$. Hearts were then reperfused for a total of 90 min. Control hearts received no pharmacological postconditioning.

At the conclusion of reperfusion in either group, the heart was dismounted from the rig and the cannula was mounted on an infusion line connected to a syringe pump (Harvard Apparatus). The mouse hearts were perfused with $1 \%(\mathrm{w} / \mathrm{v})$ of 2,3,5-triphenyltetrazolium chloride (TTC) while sitting in a bath of $1 \% \mathrm{TTC}$ at $37{ }^{\circ} \mathrm{C}$ for $10 \mathrm{~min}$ (Flow rate $=0.5 \mathrm{~mL} / \mathrm{min}$ ). Then, the pump is turned off and the heart remains in the TTC bath for an additional $5 \mathrm{~min}$. Following incubation, the heart is de-cannulated, weighed and allowed to freeze to a semi-frozen state at $-20{ }^{\circ} \mathrm{C}$ for 20 $30 \mathrm{~min}$ before the heart is sliced transversely at $1 \mathrm{~mm}$ thick slices. The slices are then weighed and fixed overnight in 10\% formalin, followed by imaging with a high-resolution camera. Planimetry of the images was conducted using ImageJ (NIH). 


\section{Spectra}
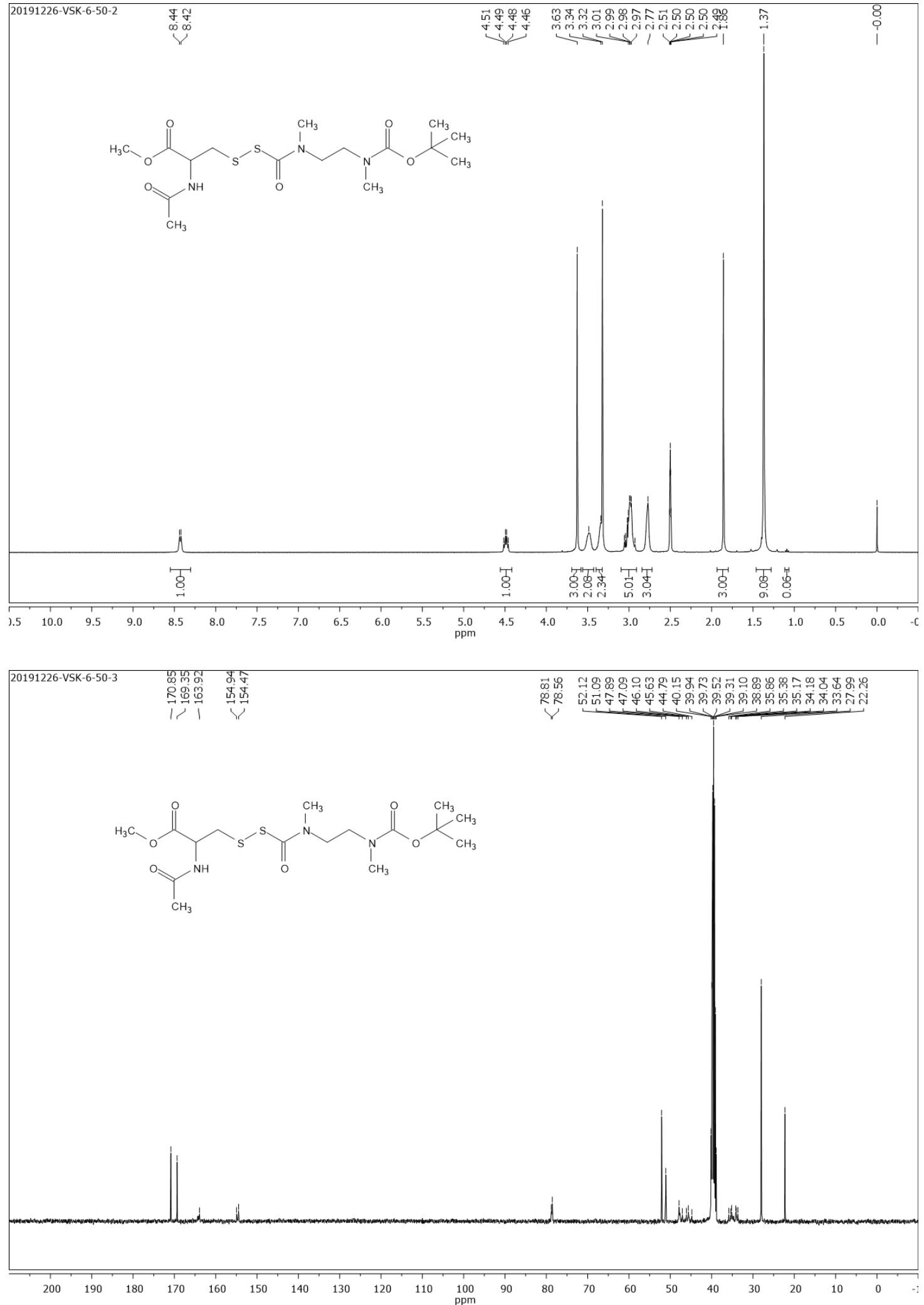

Figure S112. ${ }^{1} \mathrm{H}$ and ${ }^{13} \mathrm{C}$ NMR spectra of 4 at $24{ }^{\circ} \mathrm{C}$ 

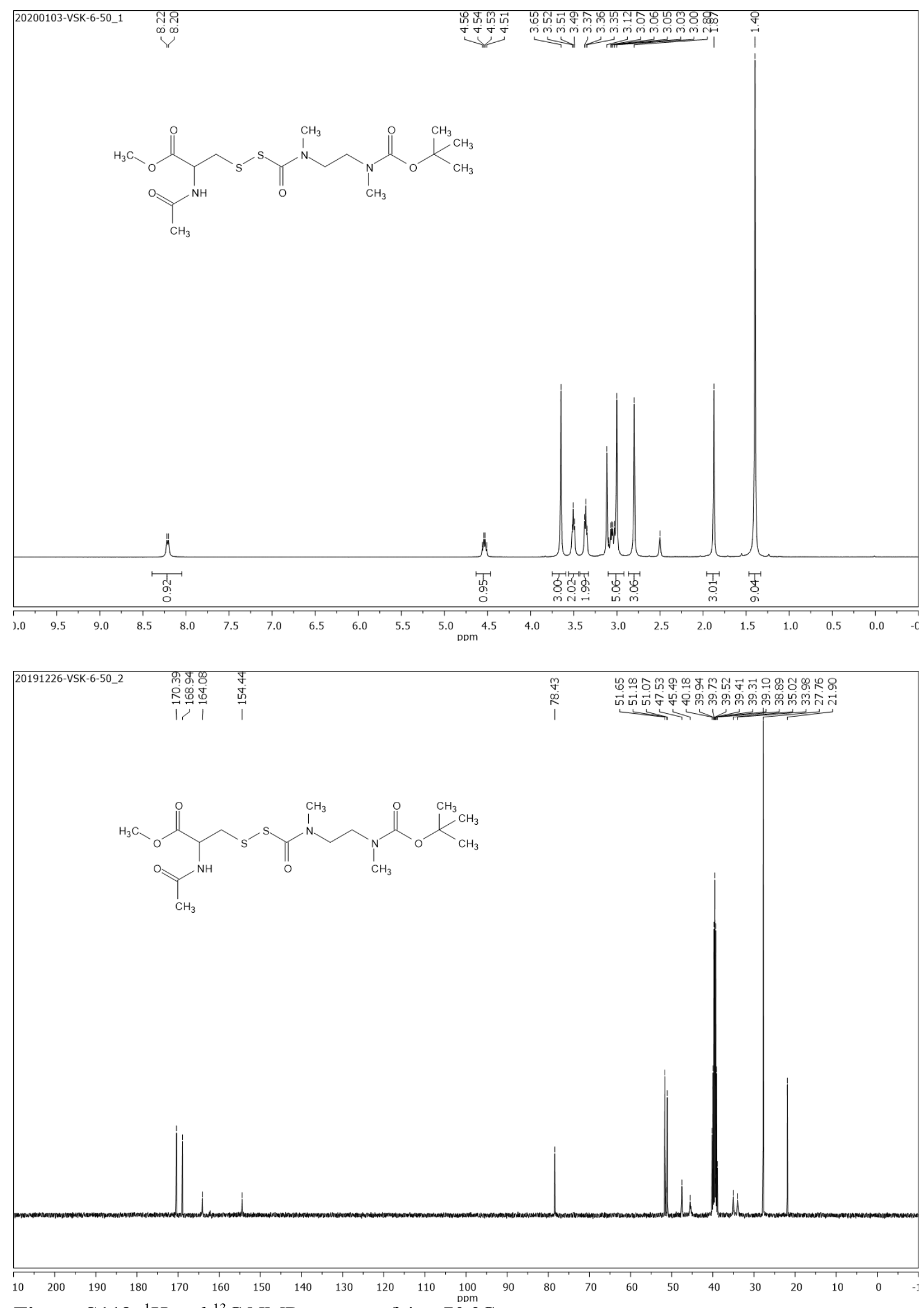

Figure S113. ${ }^{1} \mathrm{H}$ and ${ }^{13} \mathrm{C}$ NMR spectra of 4 at $70{ }^{\circ} \mathrm{C}$ 

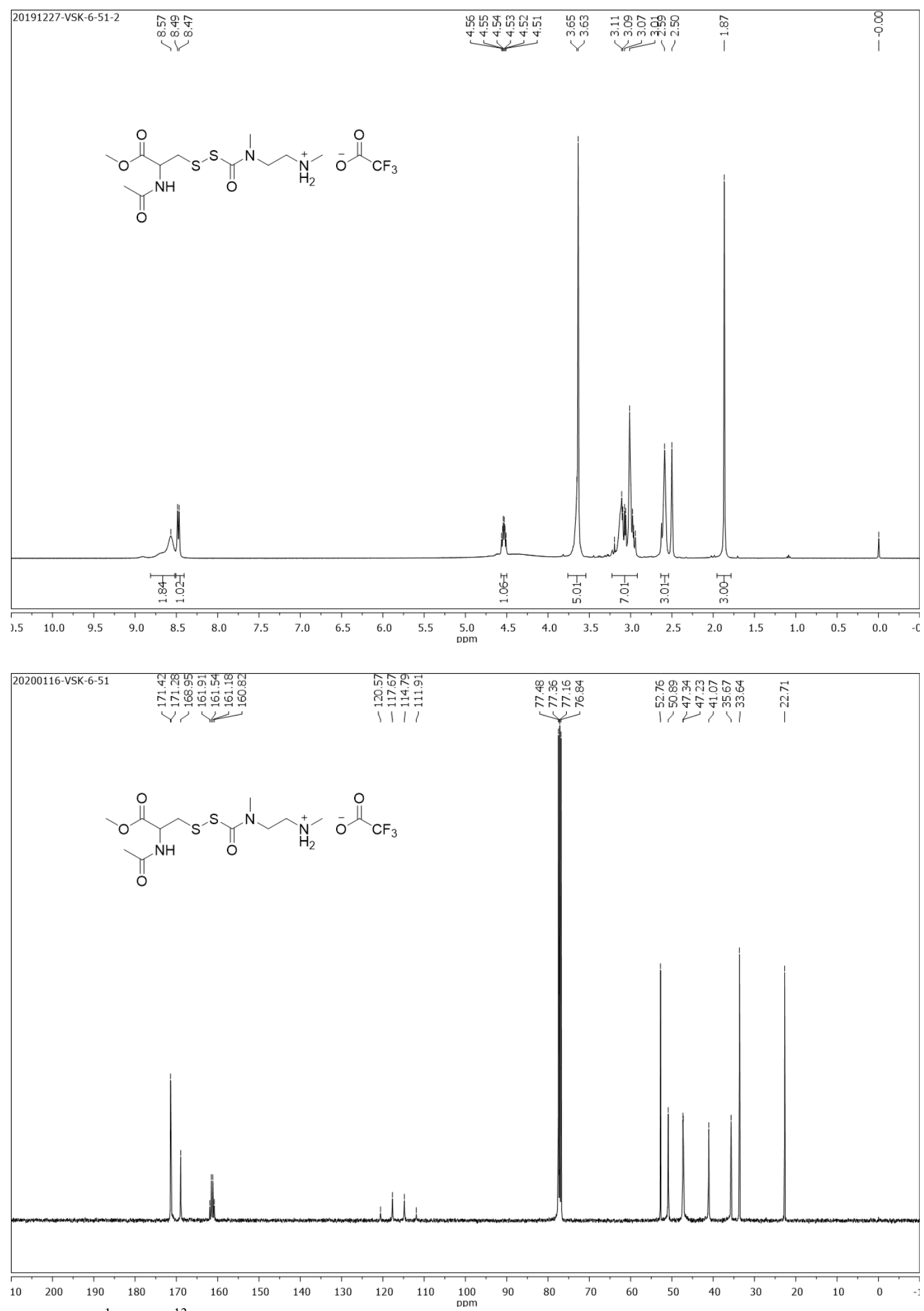

Figure S114. ${ }^{1} \mathrm{H}$ and ${ }^{13} \mathrm{C}$ NMR spectra of $1 \mathrm{a}$ 

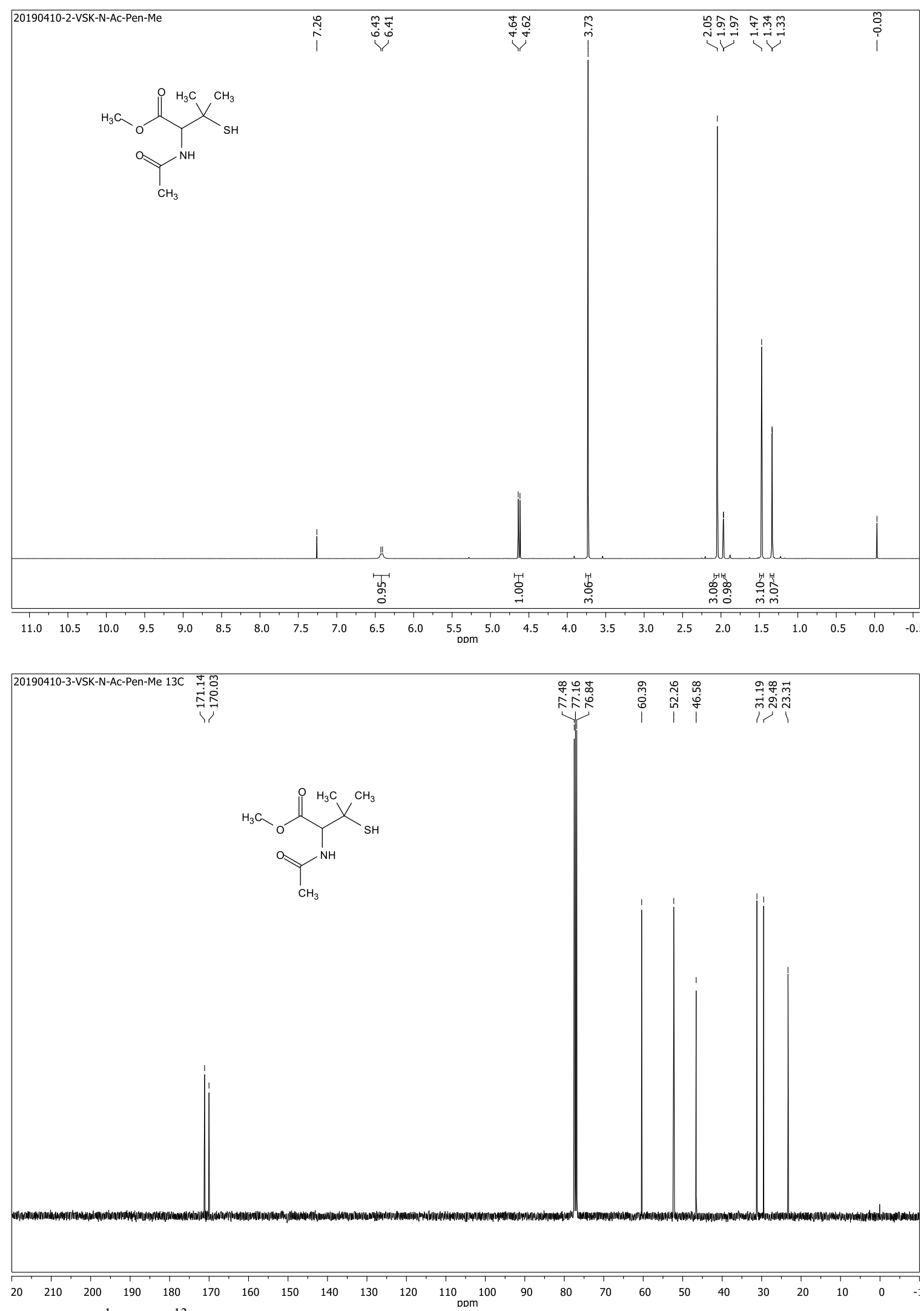

Figure S115. ${ }^{1} \mathrm{H}$ and ${ }^{13} \mathrm{C}$ NMR spectra of $\mathrm{N}$-acetyl-penicillamine methyl ester 

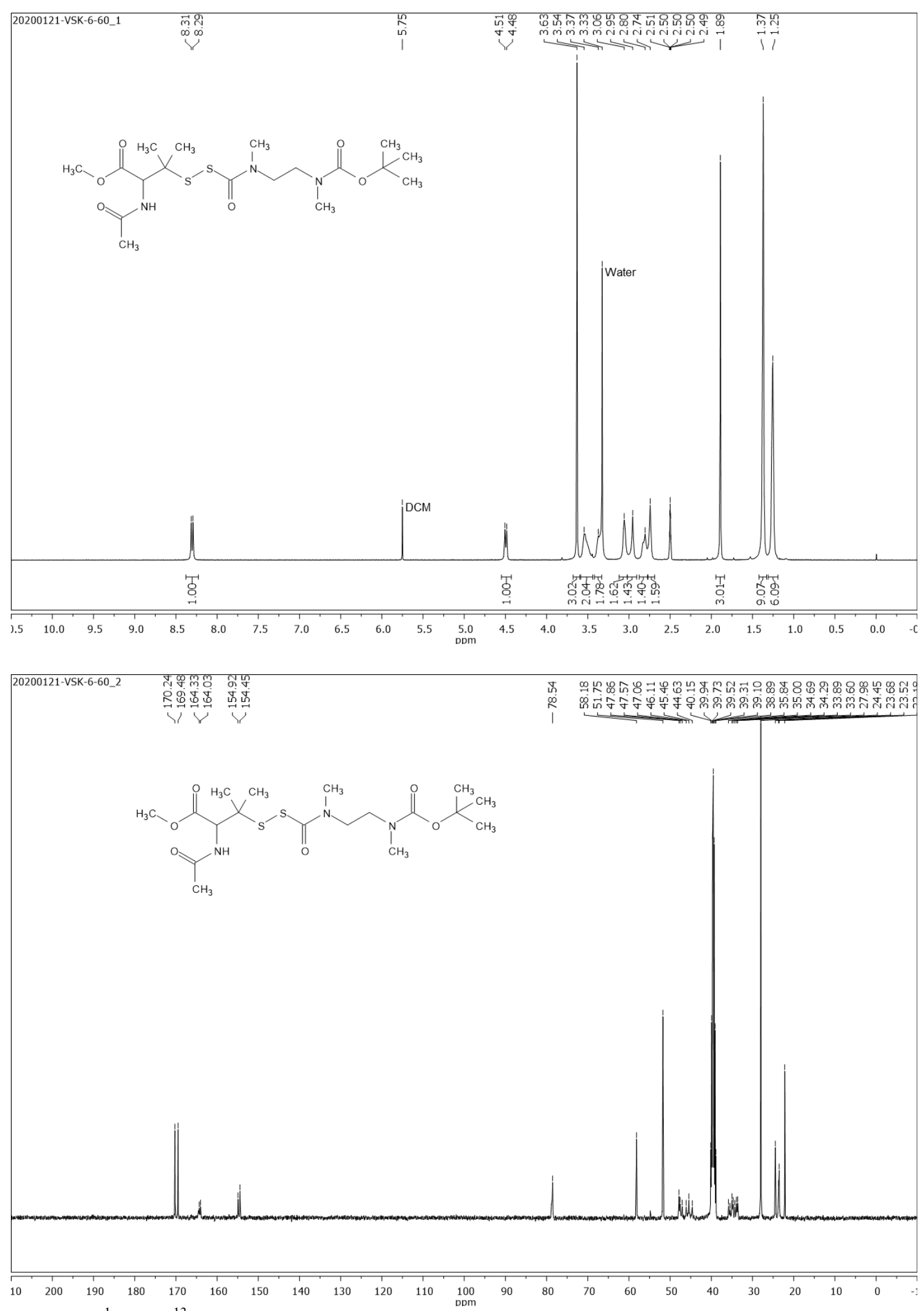

Figure S116. ${ }^{1} \mathrm{H}$ and ${ }^{13} \mathrm{C}$ NMR spectra of S1a at $24{ }^{\circ} \mathrm{C}$ 


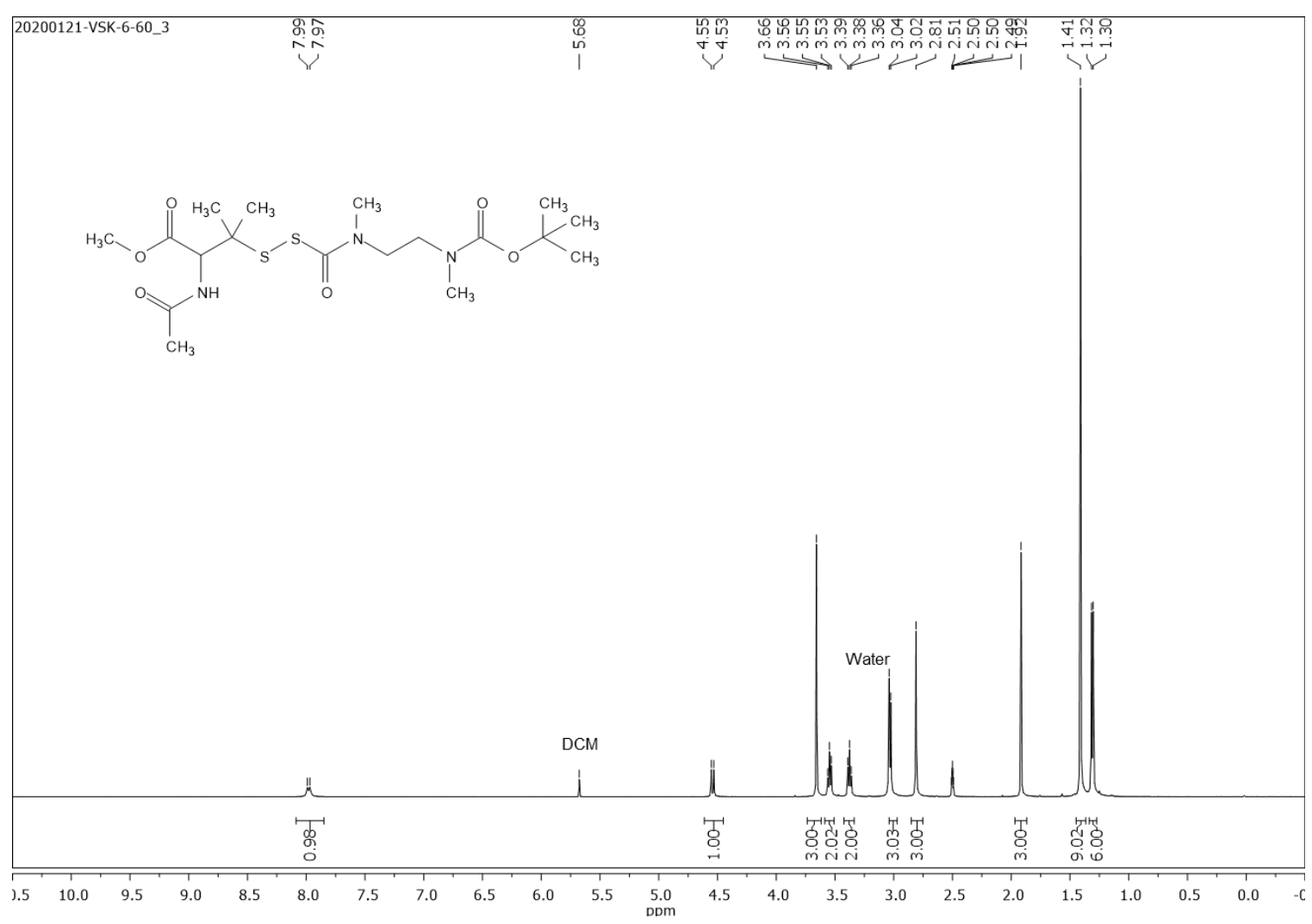

20200121-VSK-6-60_4
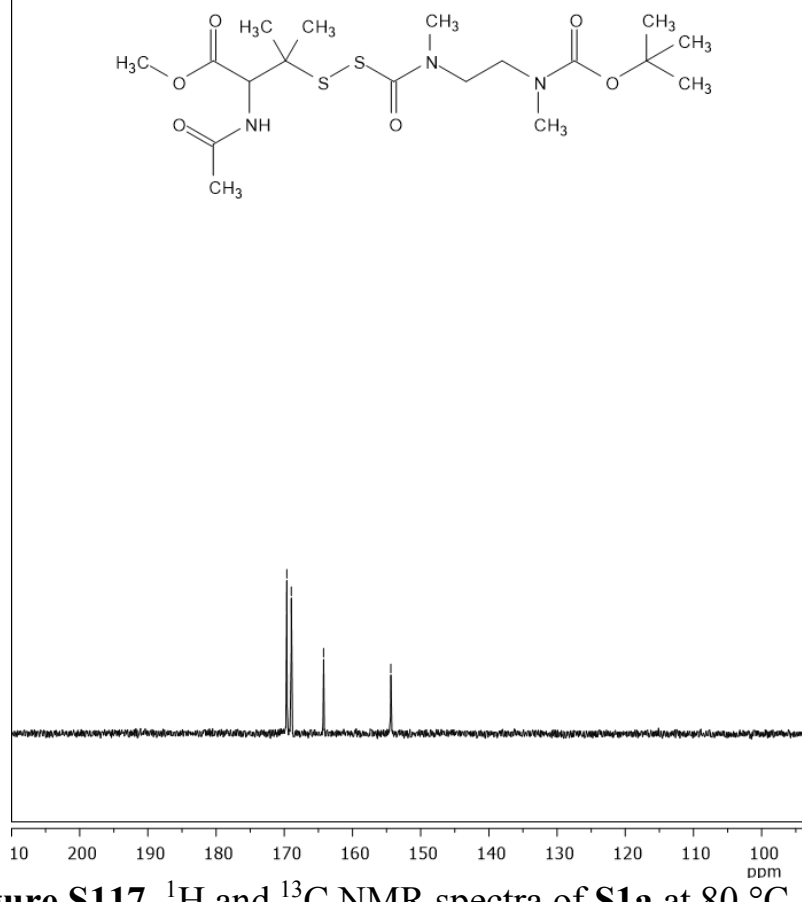

Figure S117. ${ }^{1} \mathrm{H}$ and ${ }^{13} \mathrm{C}$ NMR spectra of S1a at $80{ }^{\circ} \mathrm{C}$ 

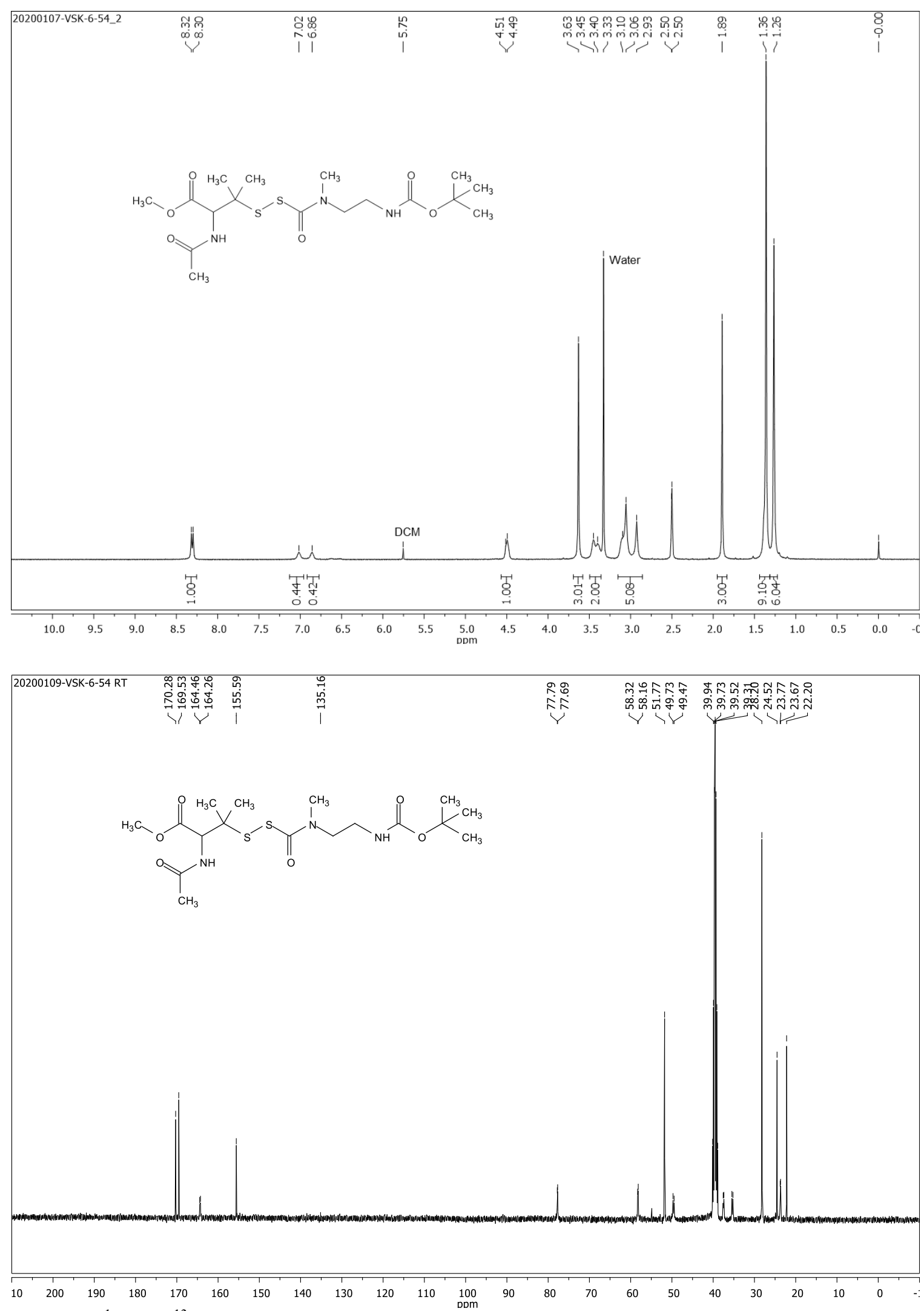

Figure S118. ${ }^{1} \mathrm{H}$ and ${ }^{13} \mathrm{C}$ NMR spectra of S1b at $24{ }^{\circ} \mathrm{C}$ 

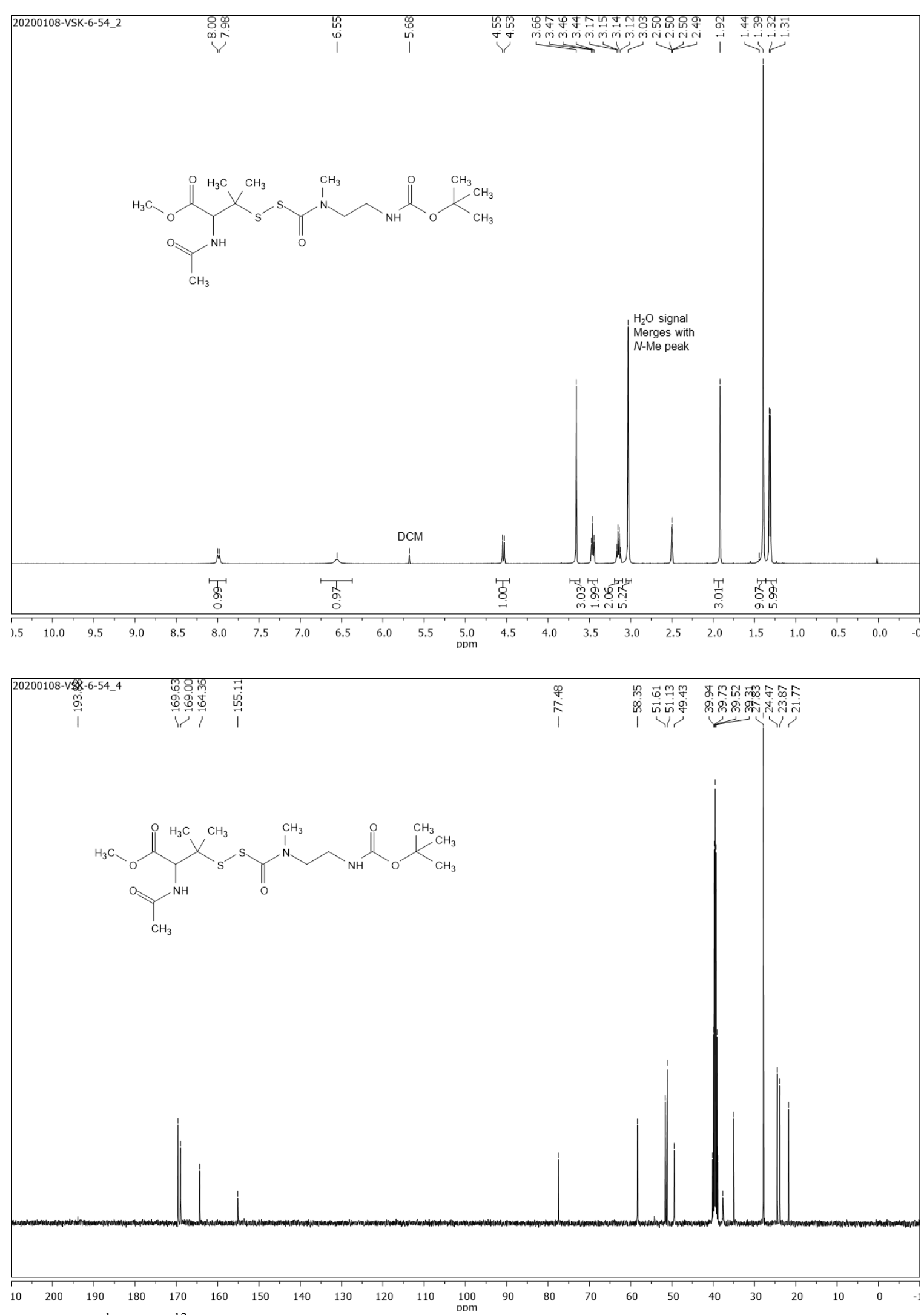

Figure S119. ${ }^{1} \mathrm{H}$ and ${ }^{13} \mathrm{C}$ NMR spectra of S1b at $80{ }^{\circ} \mathrm{C}$ 

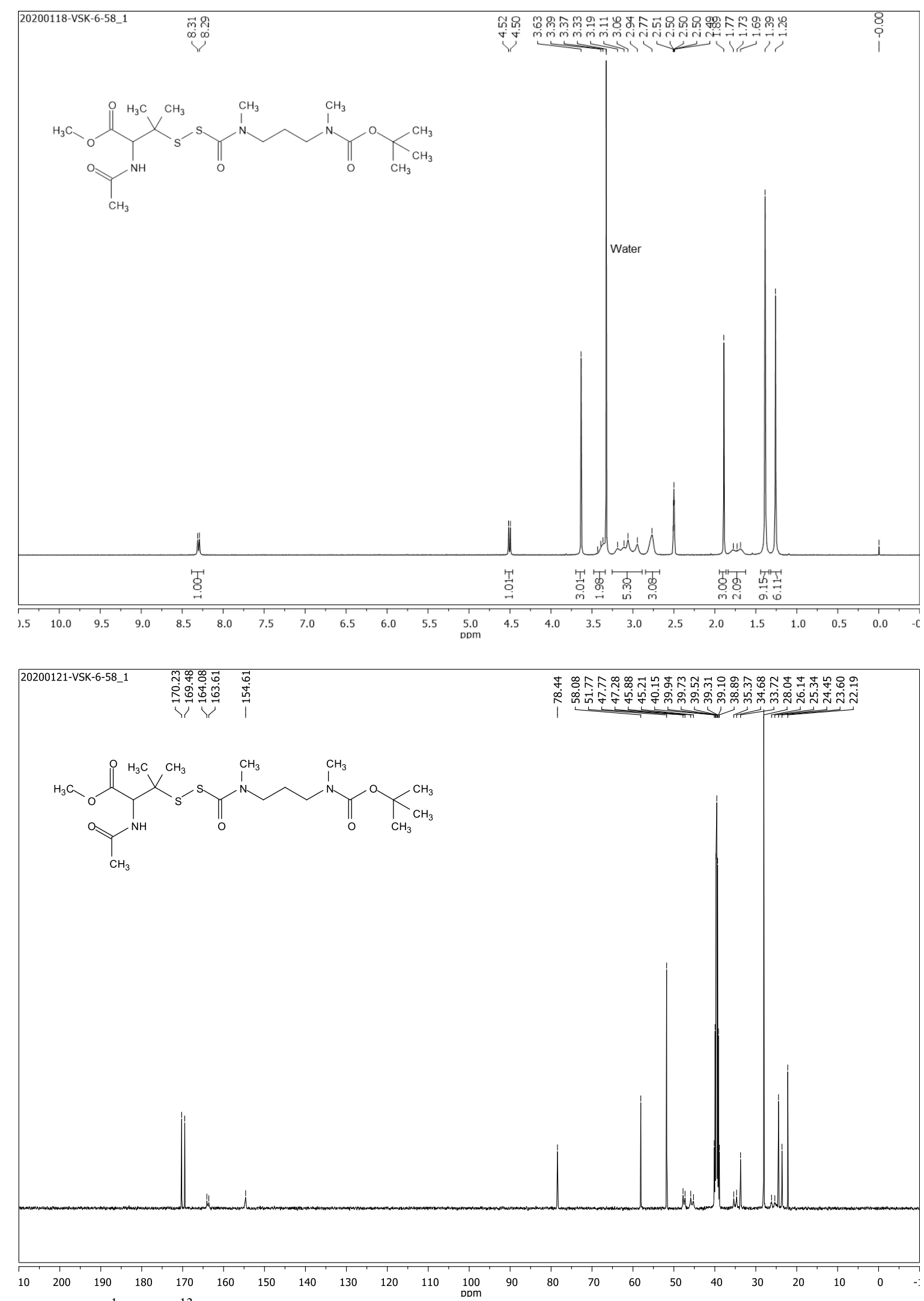

Figure S120. ${ }^{1} \mathrm{H}$ and ${ }^{13} \mathrm{C}$ NMR spectra of S1c at $24{ }^{\circ} \mathrm{C}$ 

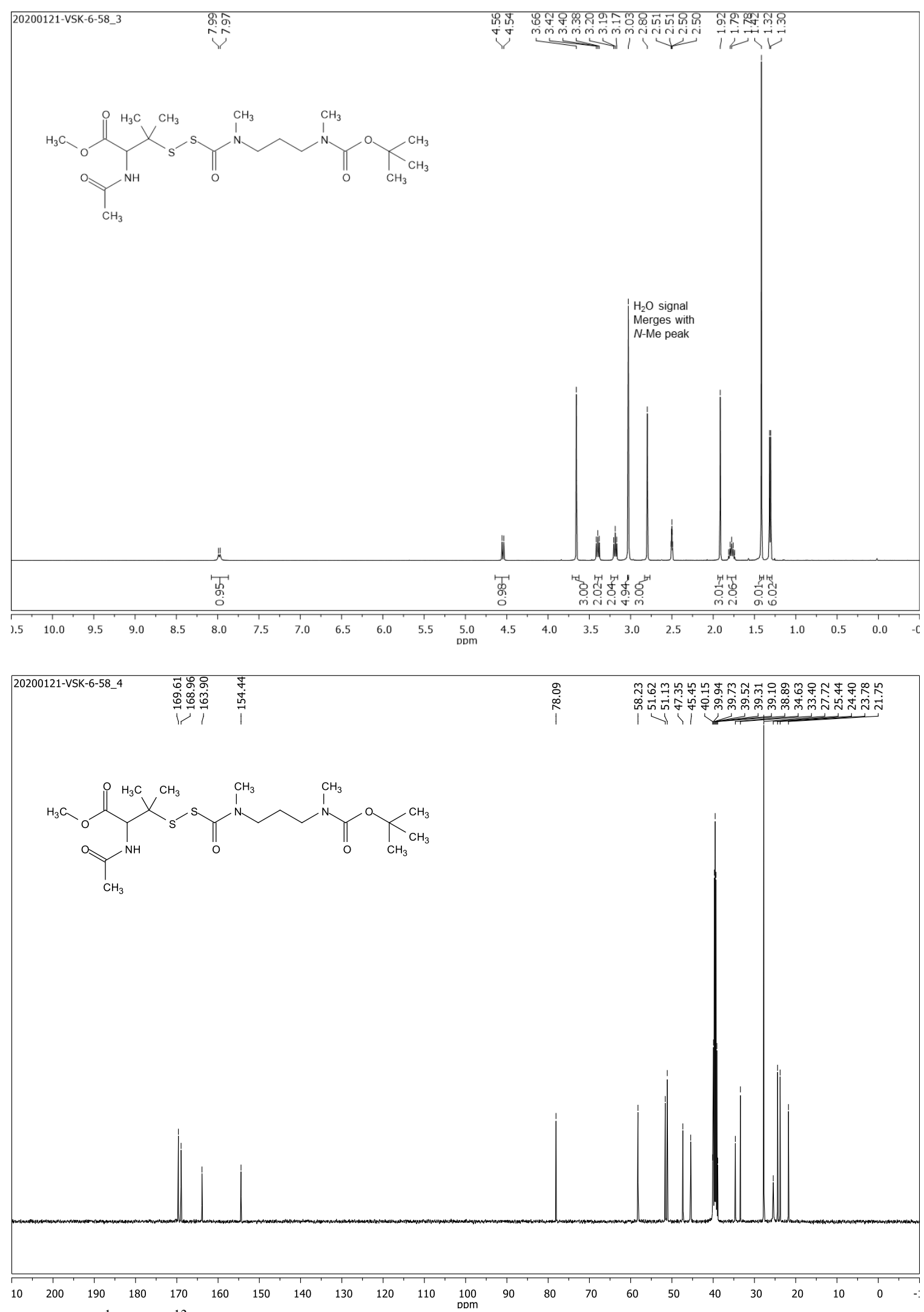

Figure S121. ${ }^{1} \mathrm{H}$ and ${ }^{13} \mathrm{C}$ NMR spectra of S1c at $80{ }^{\circ} \mathrm{C}$ 

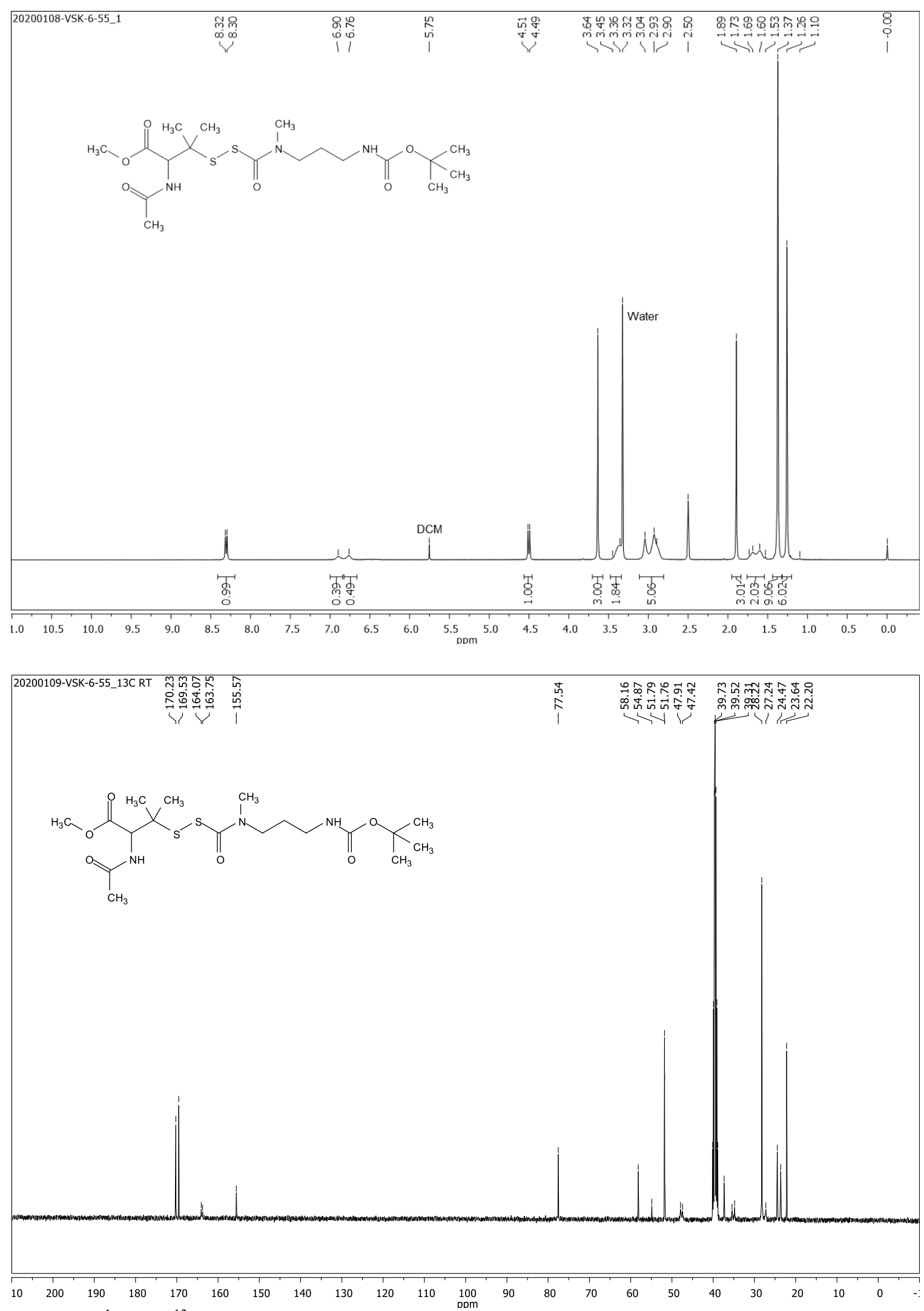

Figure S122. ${ }^{1} \mathrm{H}$ and ${ }^{13} \mathrm{C}$ NMR spectra of S1d at $24{ }^{\circ} \mathrm{C}$ 

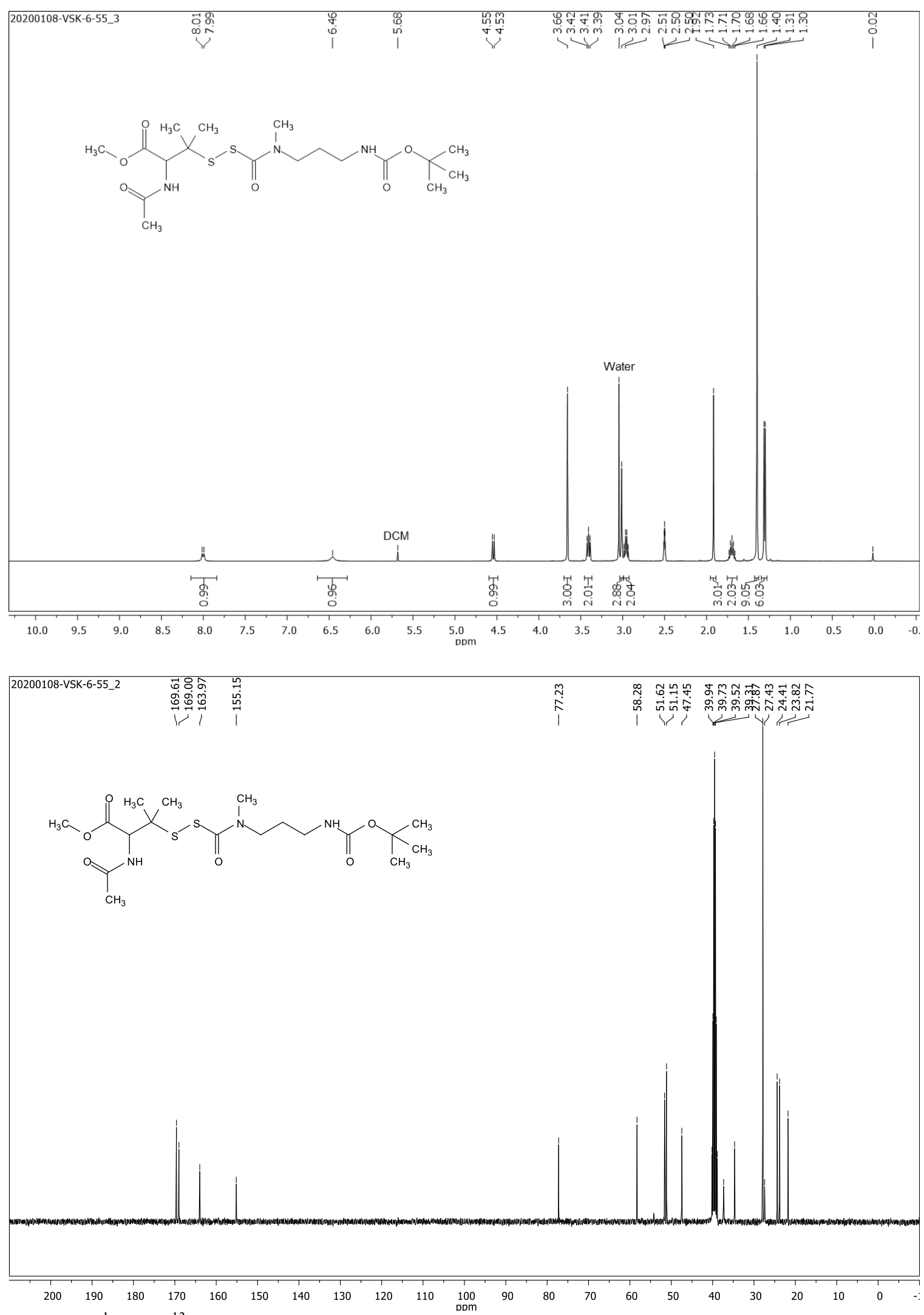

Figure S123. ${ }^{1} \mathrm{H}$ and ${ }^{13} \mathrm{C}$ NMR spectra of $\mathbf{S 1 d}$ at $80{ }^{\circ} \mathrm{C}$ 

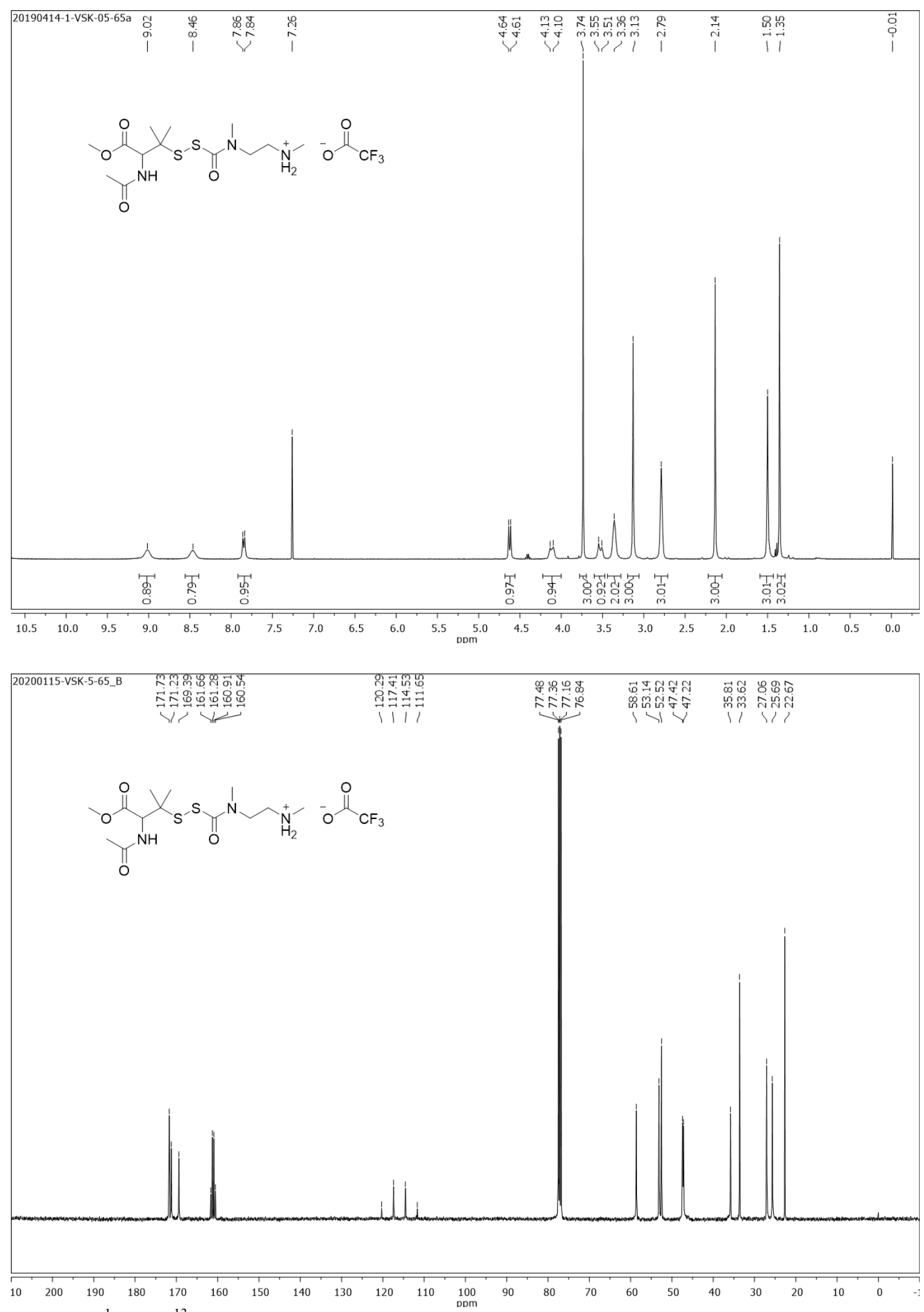

Figure S124. ${ }^{1} \mathrm{H}$ and ${ }^{13} \mathrm{C}$ NMR spectra of $7 \mathbf{a}$ at $24{ }^{\circ} \mathrm{C}$ 

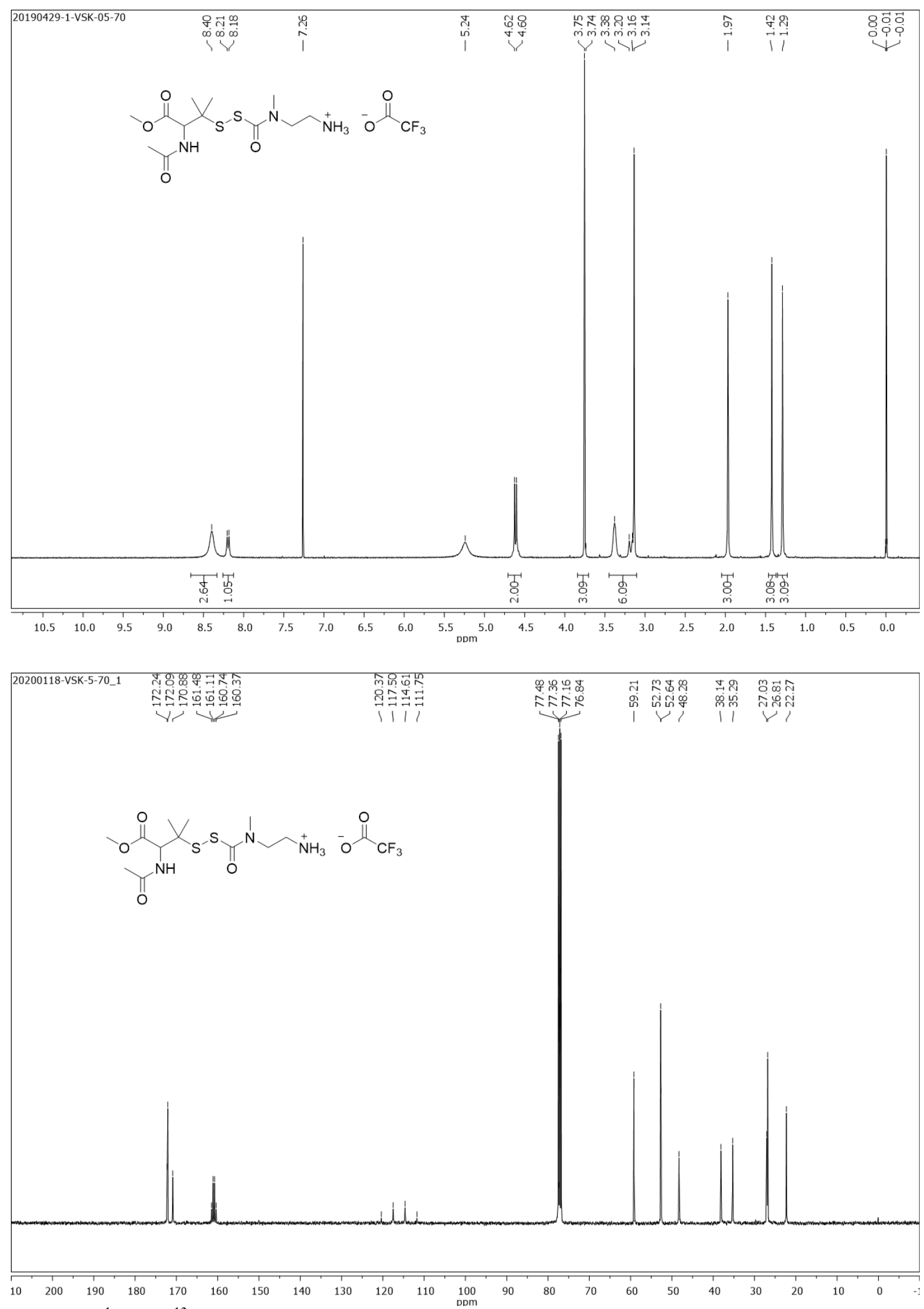

Figure S125. ${ }^{1} \mathrm{H}$ and ${ }^{13} \mathrm{C}$ NMR spectra of $7 \mathbf{b}$ at $24{ }^{\circ} \mathrm{C}$ 

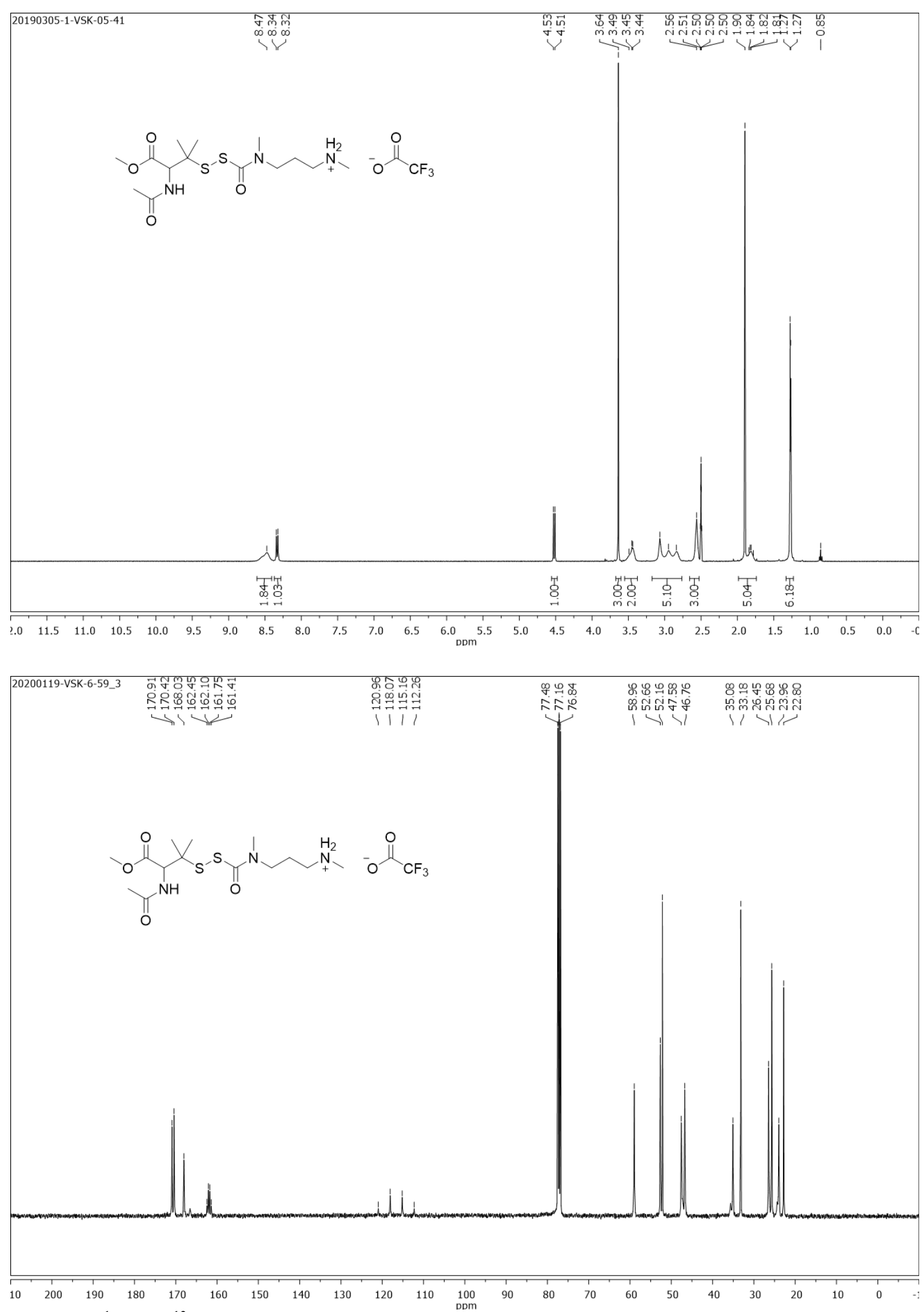

Figure S126. ${ }^{1} \mathrm{H}$ and ${ }^{13} \mathrm{C}$ NMR spectra of $7 \mathrm{c}$ at $24{ }^{\circ} \mathrm{C}$ 


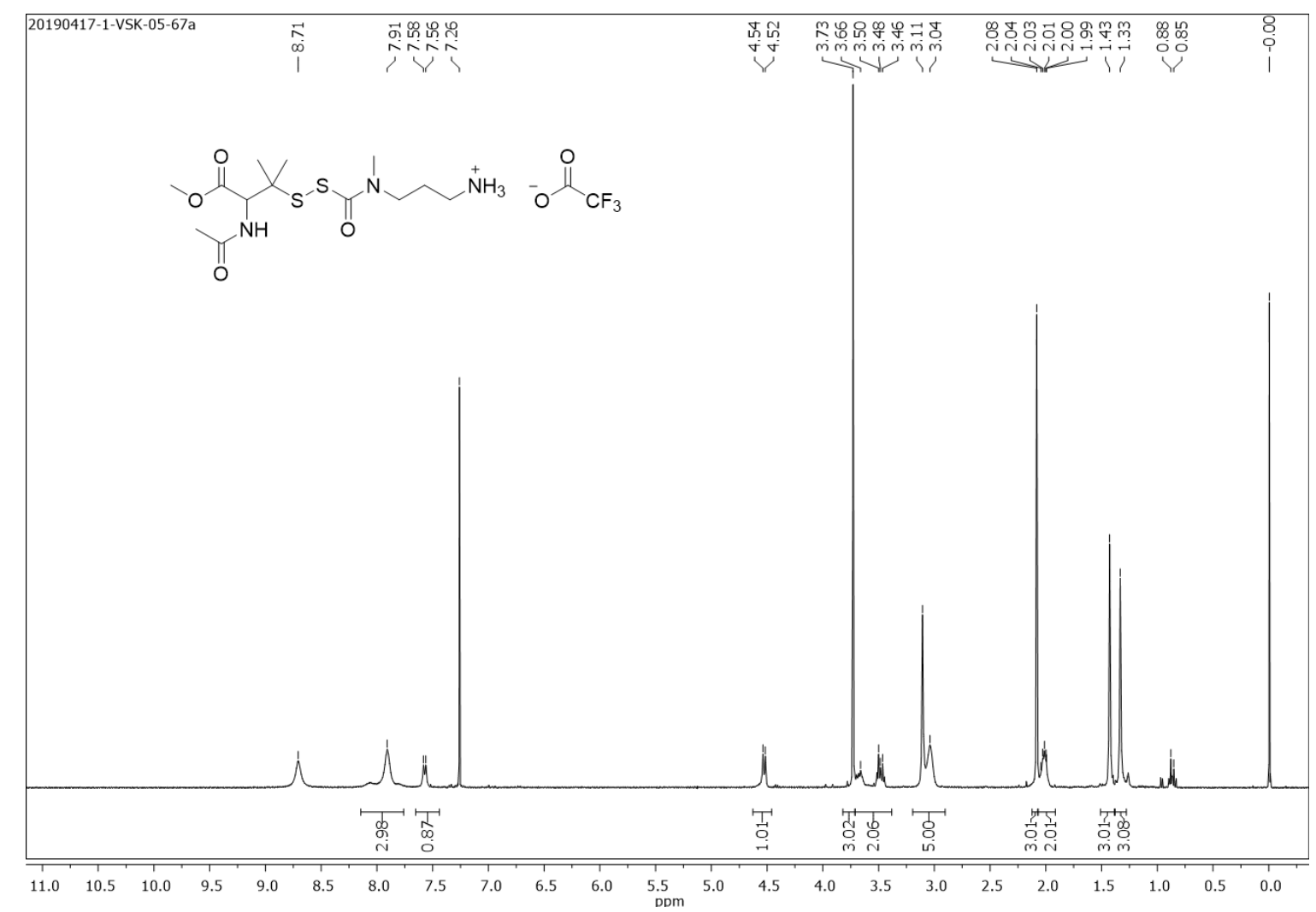

\begin{tabular}{|c|c|c|c|c|c|c|}
\hline 20200120-VSK-5-67_1 & 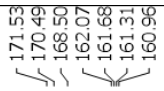 & 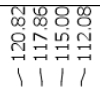 & 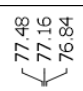 & 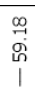 & 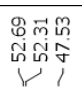 & 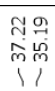 \\
\hline
\end{tabular}
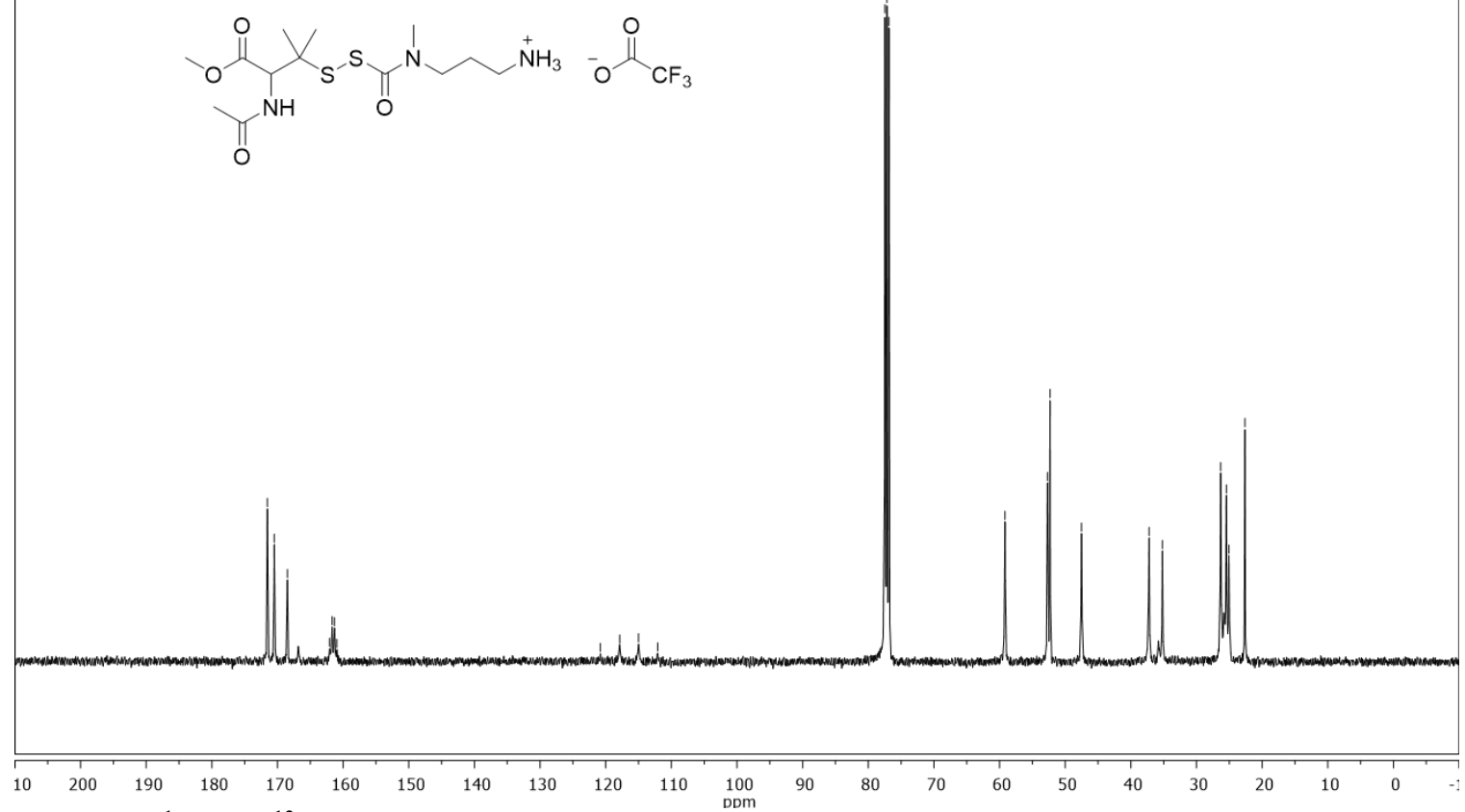

Figure S127. ${ }^{1} \mathrm{H}$ and ${ }^{13} \mathrm{C}$ NMR spectra of $7 \mathbf{d}$ at $24{ }^{\circ} \mathrm{C}$ 

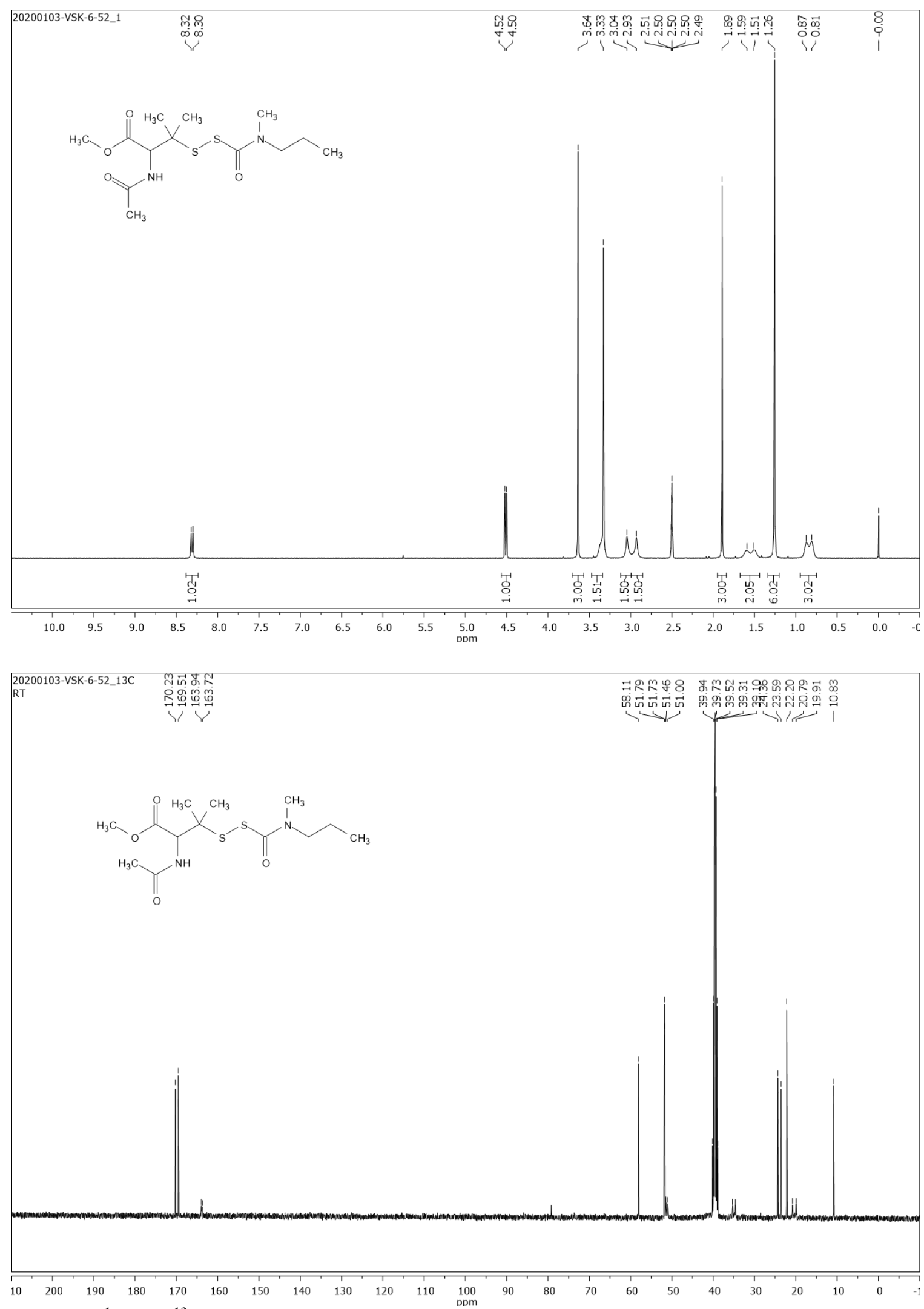

Figure S128. ${ }^{1} \mathrm{H}$ and ${ }^{13} \mathrm{C}$ NMR spectra of 8 at $24{ }^{\circ} \mathrm{C}$ 

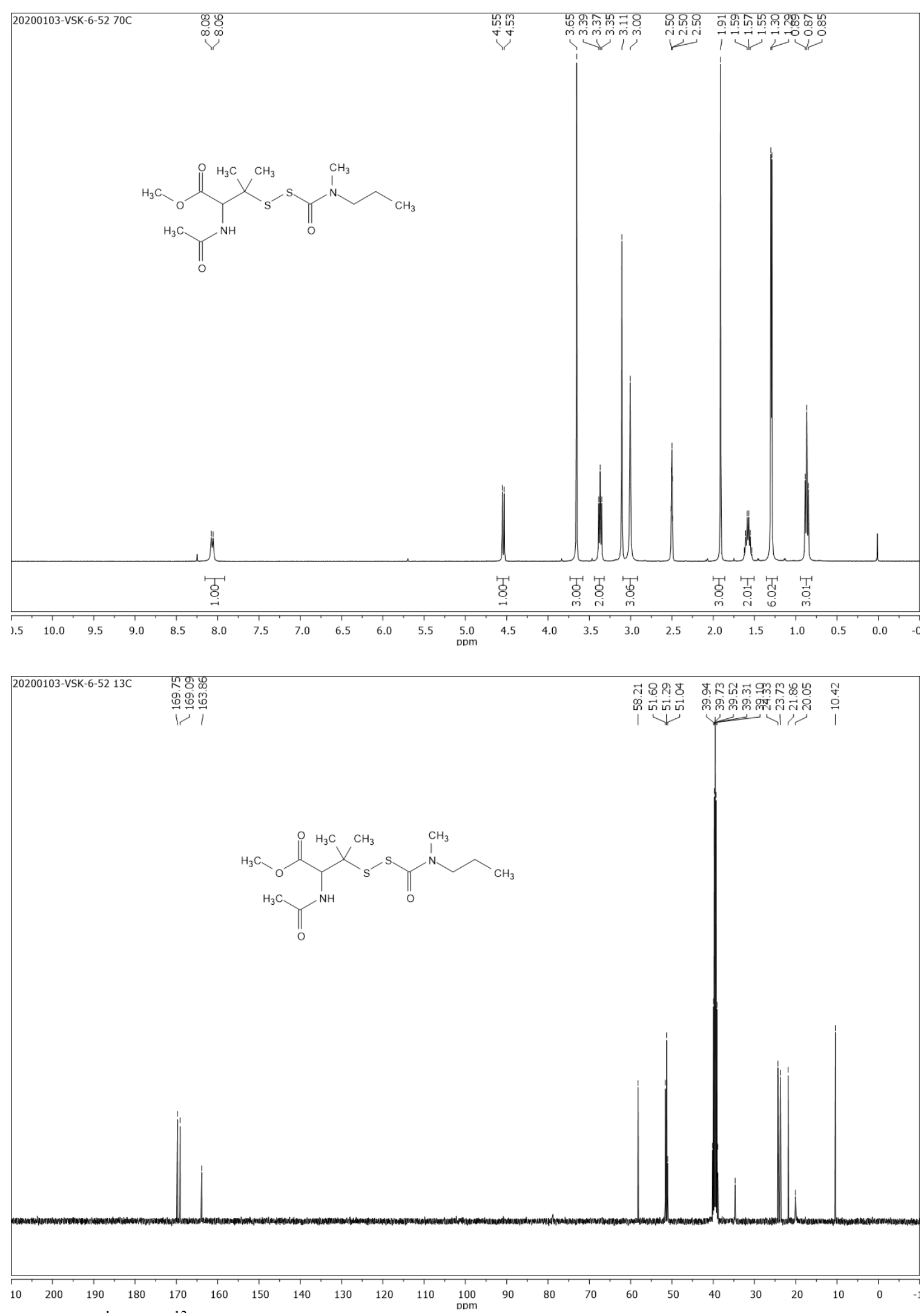

Figure S129. ${ }^{1} \mathrm{H}$ and ${ }^{13} \mathrm{C}$ NMR spectra of 8 at $70{ }^{\circ} \mathrm{C}$ 


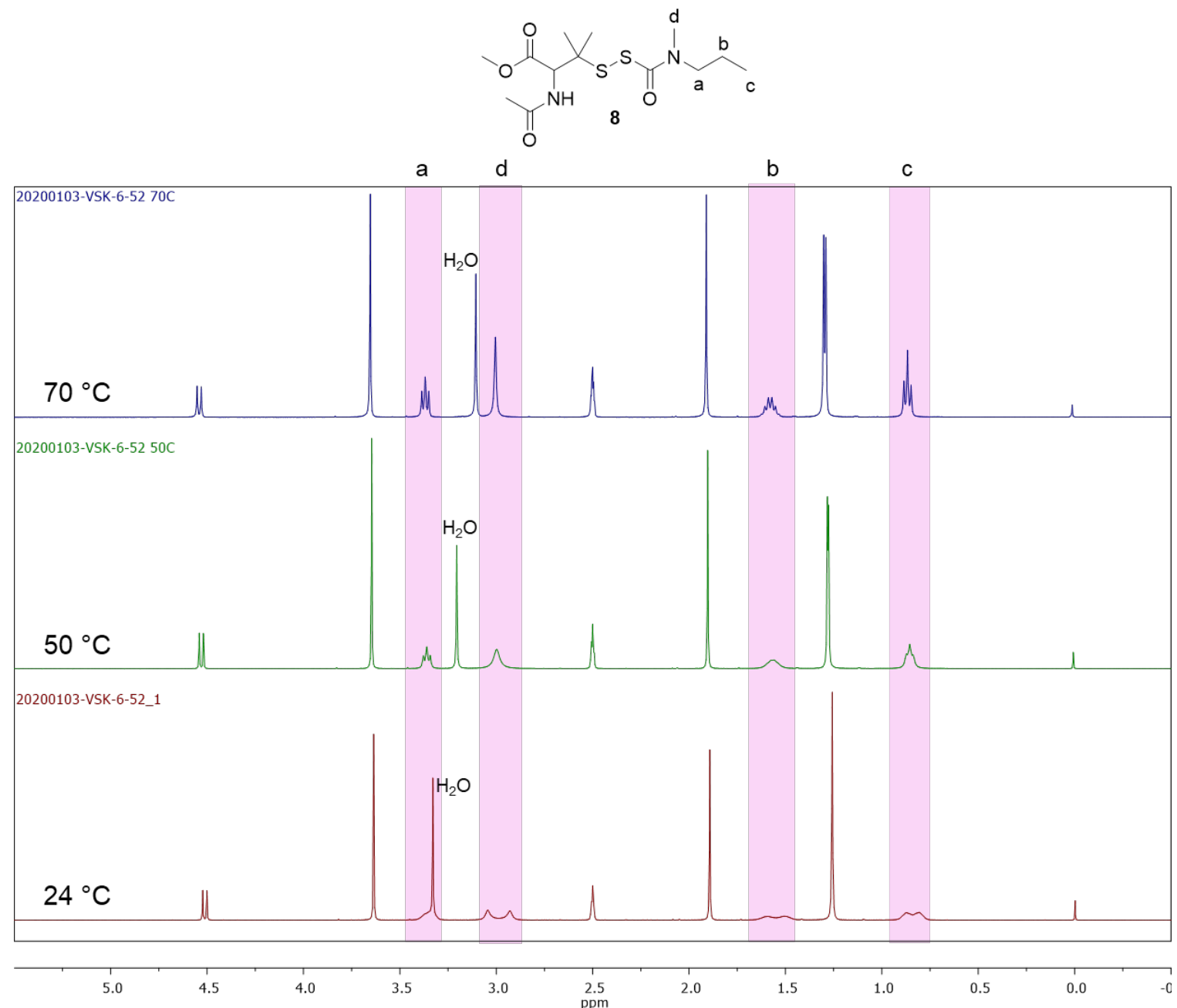

Figure S130. Variable-temperature ${ }^{1} \mathrm{H}$ NMR spectra of 8 in DMSO- $d_{6}$ from 24 to $70{ }^{\circ} \mathrm{C}$ demonstrating the presence of rotamers. 


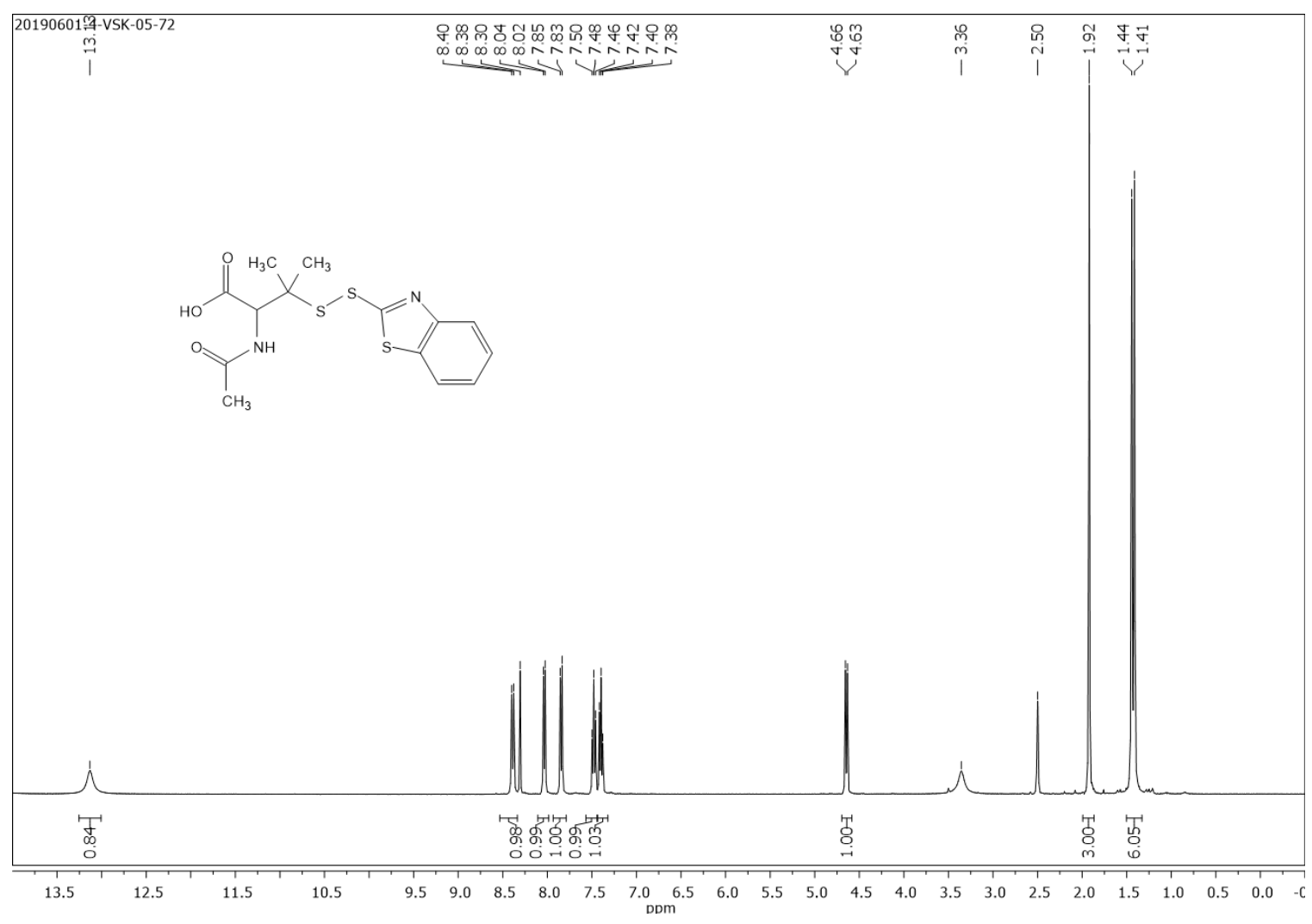

20190601-5-VSK-05-72
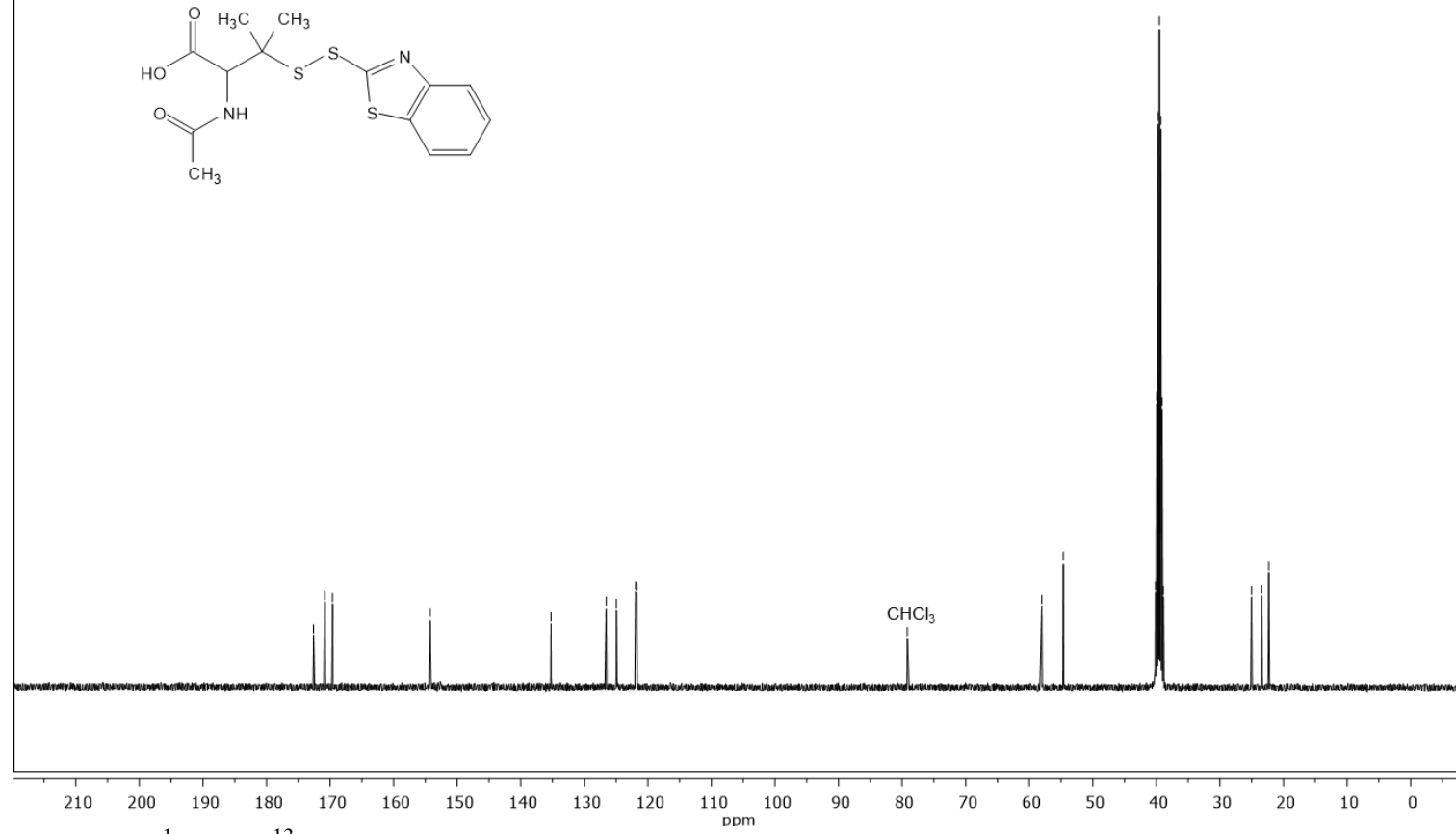

Figure S131. ${ }^{1} \mathrm{H}$ and ${ }^{13} \mathrm{C}$ NMR spectra of $\mathbf{S 2}$ 


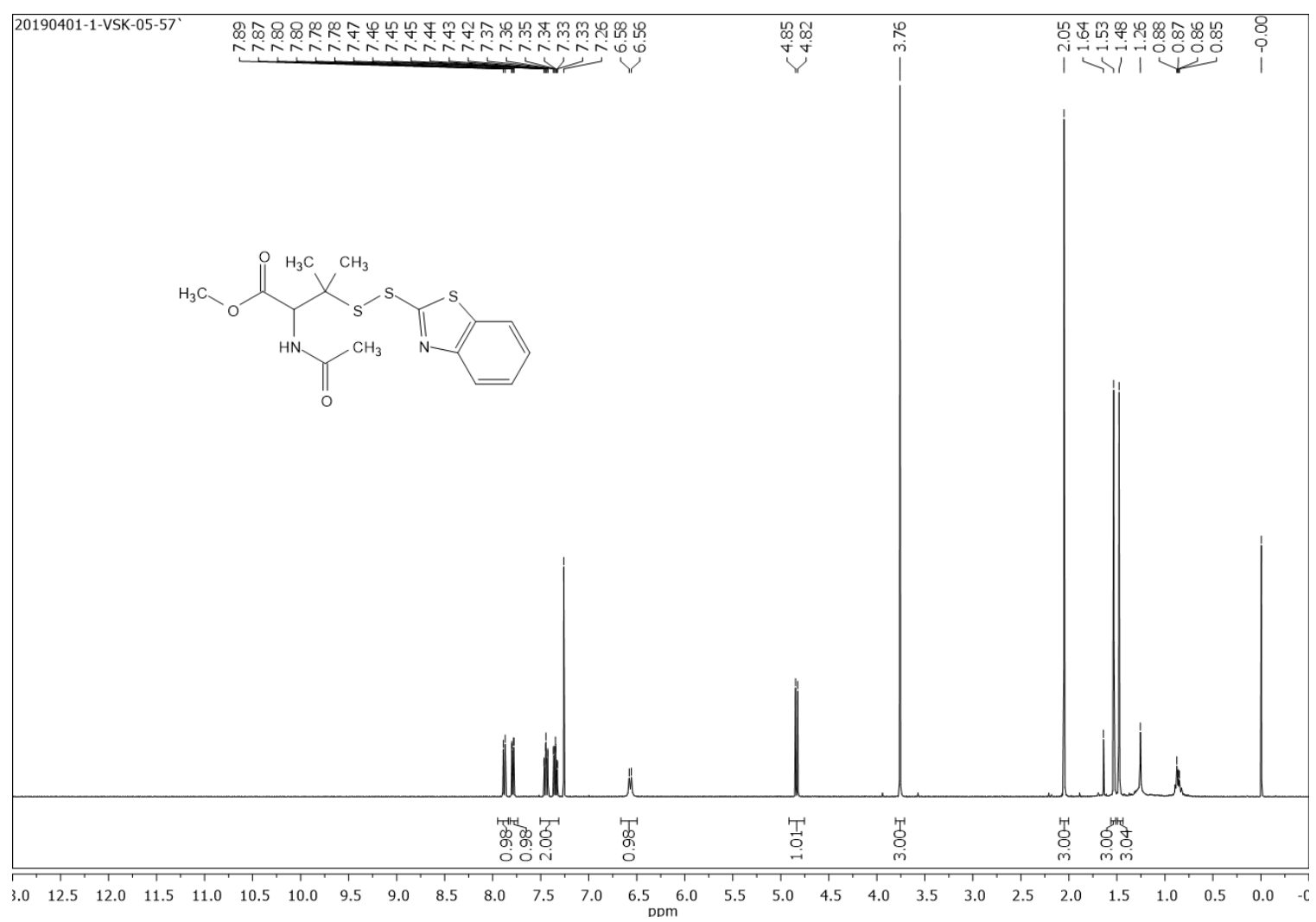

20190410-6-VSK-05-57
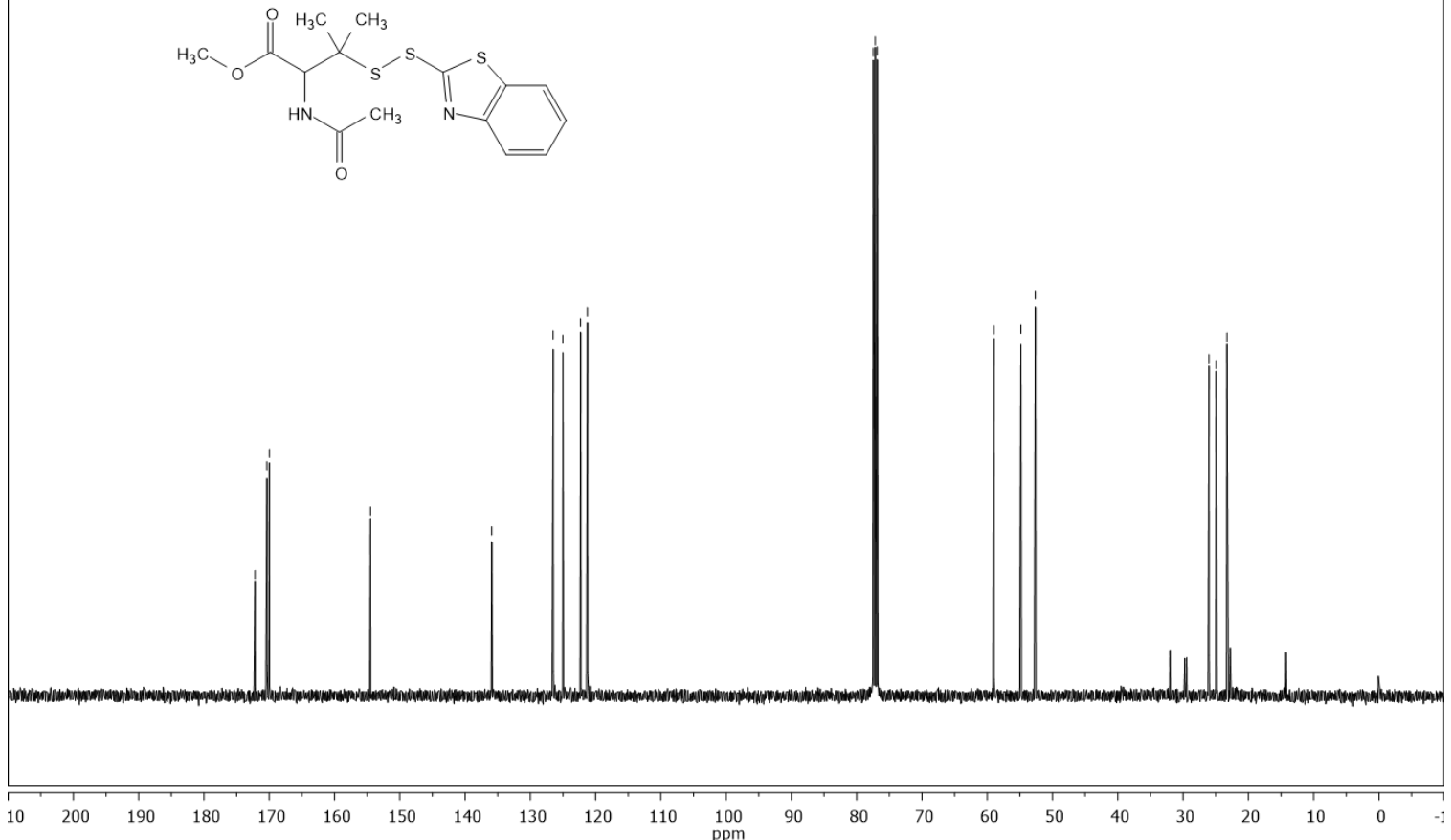

Figure S132. ${ }^{1} \mathrm{H}$ and ${ }^{13} \mathrm{C}$ NMR spectra of $\mathbf{S 3}$ 

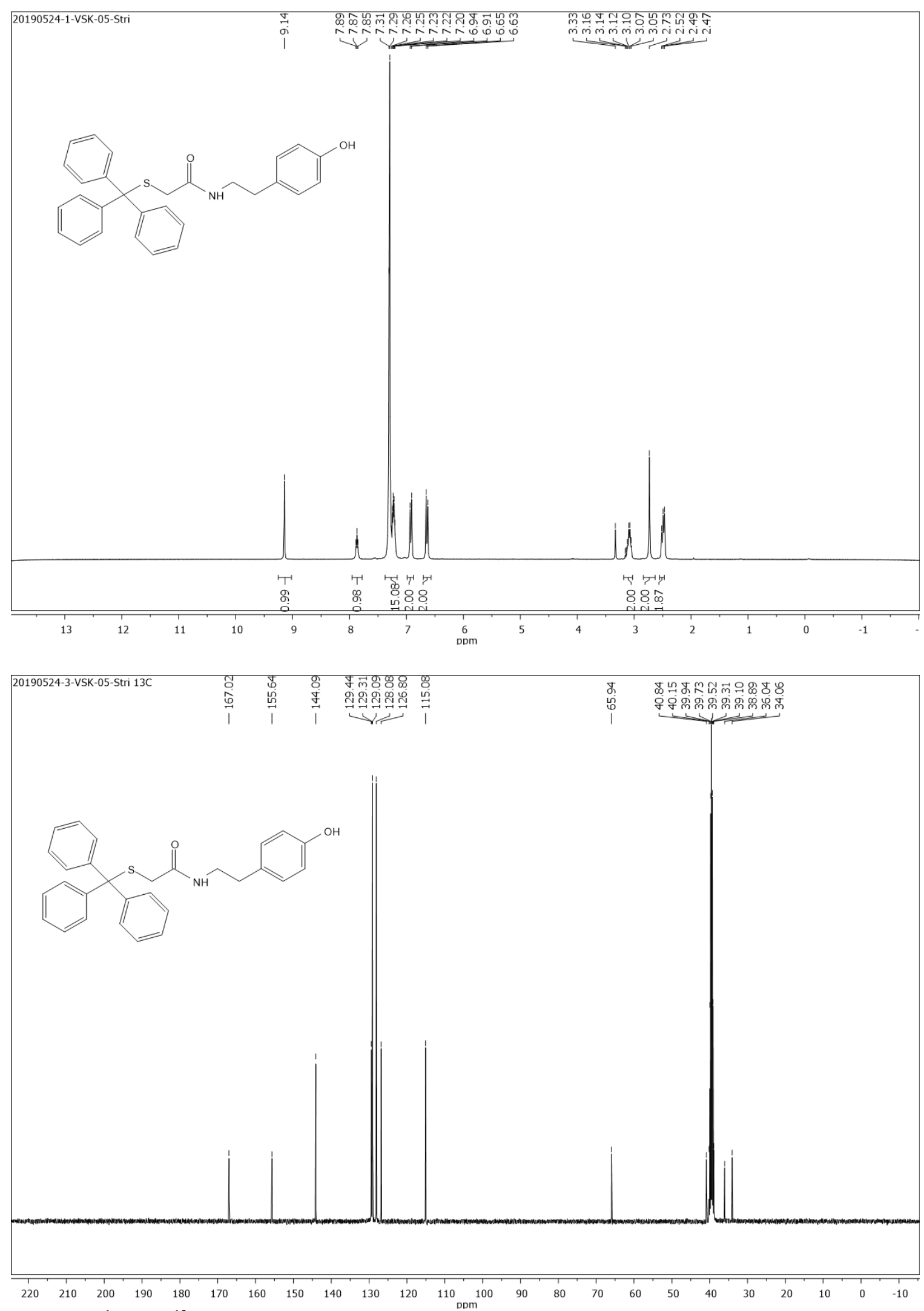

Figure S133. ${ }^{1} \mathrm{H}$ and ${ }^{13} \mathrm{C}$ NMR spectra of $\mathbf{S 4}$ 

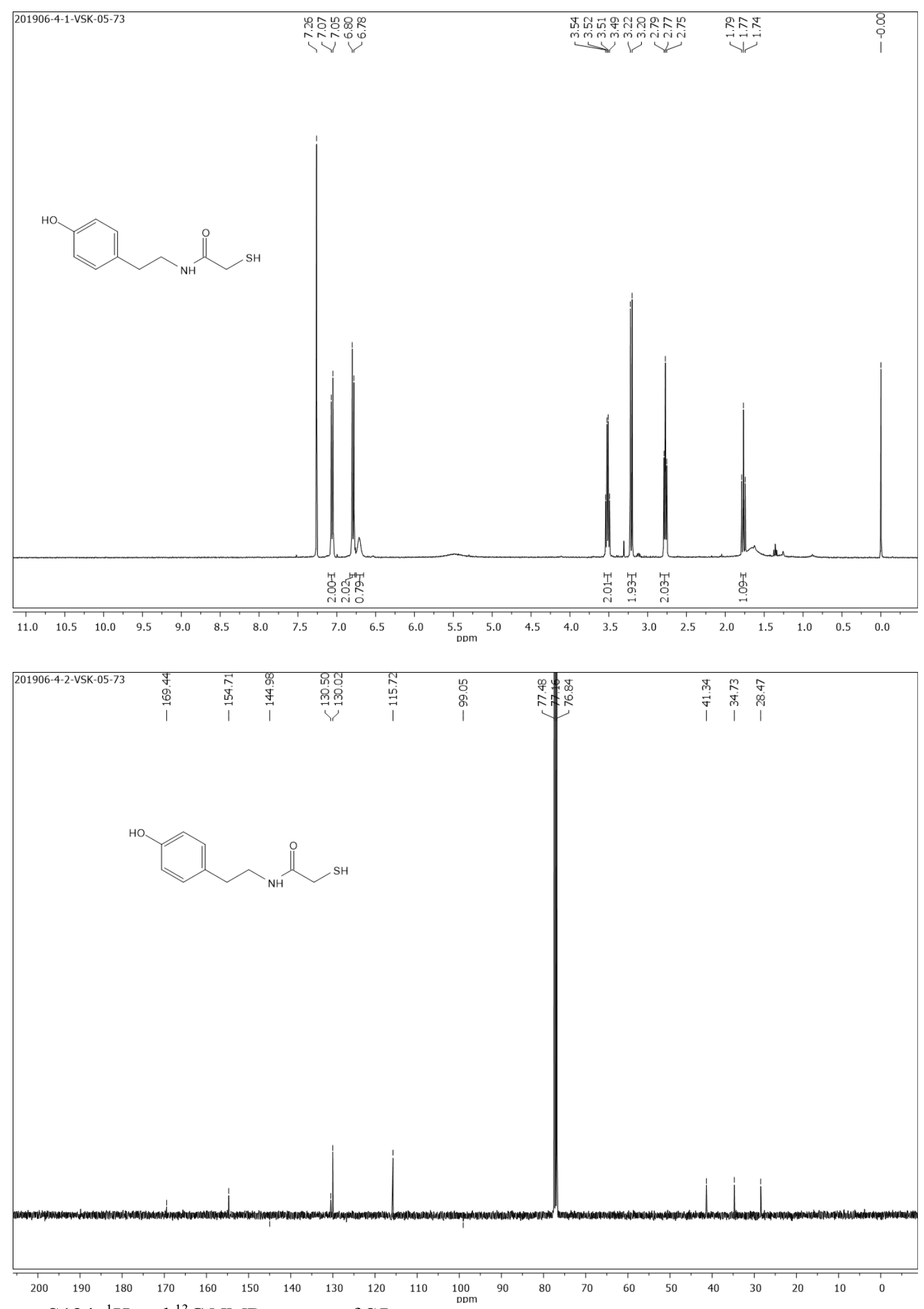

Figure S134. ${ }^{1} \mathrm{H}$ and ${ }^{13} \mathrm{C}$ NMR spectra of S5

S94 


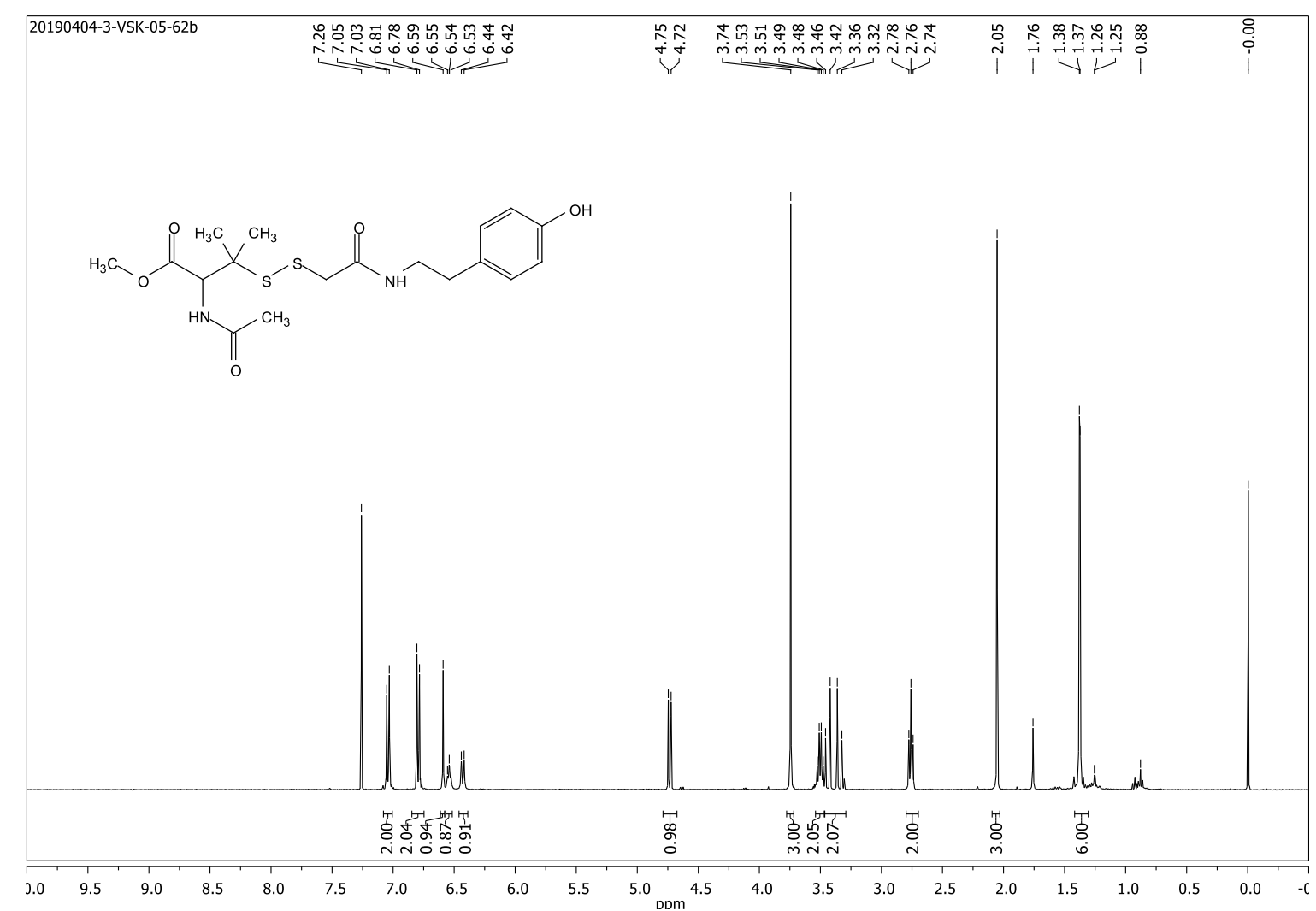

\begin{tabular}{|c|c|c|c|c|c|c|c|c|c|}
\hline 20190410-5-VSK-05-62 & 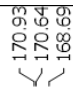 & 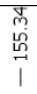 & 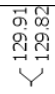 & 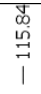 & 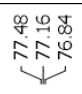 & 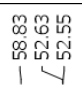 & 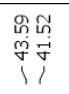 & $\begin{array}{l}\hat{0} \\
\vec{m} \\
i\end{array}$ & 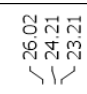 \\
\hline
\end{tabular}

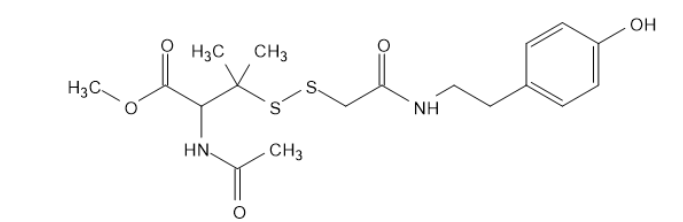

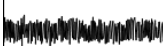




\section{References}

(1) Meyer, Y.; Richard, J.-A.; Delest, B.; Noack, P.; Renard, P.-Y.; Romieu, A. A comparative study of the self-immolation of para-aminobenzylalcohol and hemithioaminal-based linkers in the context of protease-sensitive fluorogenic probes. Org. Biomol. Chem. 2010, 8, 1777-1780.

(2) Devine, W. G.; Diaz-Gonzalez, R.; Ceballos-Perez, G.; Rojas, D.; Satoh, T.; Tear, W.; Ranade, R. M.; Barros-Álvarez, X.; Hol, W. G. J.; Buckner, F. S.; Navarro, M.; Pollastri, M. P. From Cells to Mice to Target: Characterization of NEU-1053 (SB-443342) and Its Analogues for Treatment of Human African Trypanosomiasis. ACS Infect. Dis. 2017, 3, 225-236.

(3) Li, J.; Sha, Y. A Convenient Synthesis of Amino Acid Methyl Esters. Molecules 2008, 13, 1111-1119.

(4) Bogdándi, V.; Ida, T.; Sutton, T. R.; Bianco, C.; Ditrói, T.; Koster, G.; Henthorn, H. A.; Minnion, M.; Toscano, J. P.; van der Vliet, A.; Pluth, M. D.; Feelisch, M.; Fukuto, J. M.; Akaike, T.; Nagy, P. Speciation of reactive sulfur species and their reactions with alkylating agents: do we have any clue about what is present inside the cell? Br. J. Pharmacol. 2019, 176, 646-670.

(5) Cline, M. R.; Tu, C.; Silverman, D. N.; Toscano, J. P. Detection of nitroxyl (HNO) by membrane inlet mass spectrometry. Free Radical. Biol. Med. 2011, 50, 1274-1279.

(6) Powell, C. R.; Dillon, K. M.; Wang, Y.; Carrazzone, R. J.; Matson, J. B. A Persulfide Donor Responsive to Reactive Oxygen Species: Insights into Reactivity and Therapeutic Potential. Angew. Chem., Int. Ed. 2018, 57, 6324-6328.

(7) Ishiyama, M.; Miyazono, Y.; Sasamoto, K.; Ohkura, Y.; Ueno, K. A highly water-soluble disulfonated tetrazolium salt as a chromogenic indicator for $\mathrm{NADH}$ as well as cell viability. Talanta 1997, 44, 1299-1305.

(8) Tominaga, H.; Ishiyama, M.; Ohseto, F.; Sasamoto, K.; Hamamoto, T.; Suzuki, K.; Watanabe, M. A water-soluble tetrazolium salt useful for colorimetric cell viability assay. Anal. Commun. 1999, 36, 47-50.

(9) Hofgaard, J. P.; Sigurdardottir, K. S.; Treiman, M. Protection by 6-aminonicotinamide against oxidative stress in cardiac cells. Pharmacol. Res. 2006, 54, 303-310.

(10) Sun, J.; Aponte, A. M.; Menazza, S.; Gucek, M.; Steenbergen, C.; Murphy, E. Additive cardioprotection by pharmacological postconditioning with hydrogen sulfide and nitric oxide donors in mouse heart: S-sulfhydration vs. S-nitrosylation. Cardiovasc. Res. 2016, 110, 96-106.

(11) Rossello, X.; Hall, A. R.; Bell, R. M.; Yellon, D. M. Characterization of the Langendorff Perfused Isolated Mouse Heart Model of Global Ischemia-Reperfusion Injury:Impact of Ischemia and Reperfusion Length on Infarct Size and LDH Release. J. Cardiovasc. Pharmacol. Ther. 2016, 21, 286-295.

(12) Bell, R. M.; Mocanu, M. M.; Yellon, D. M. Retrograde heart perfusion: The Langendorff technique of isolated heart perfusion. J. Mol. Cell. Cardiol. 2011, 50, 940-950. 